\title{
Closed Fuel Cycle Waste Treatment Strategy
}

\author{
J.D. Vienna, et. al.
}

February 2015

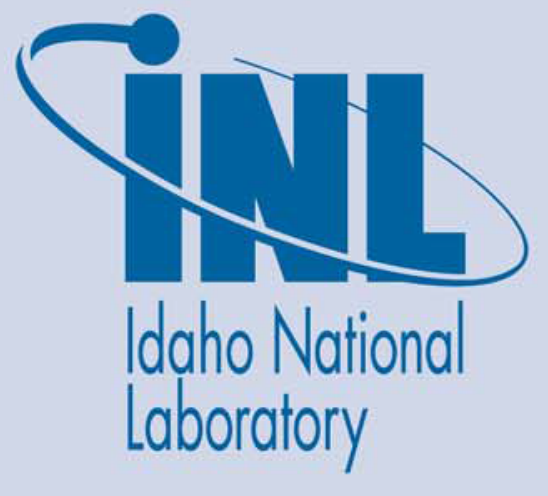

The INL is a U.S. Department of Energy National Laboratory operated by Battelle Energy Alliance 
INL/EXT-15-34504

\title{
Closed Fuel Cycle Waste Treatment Strategy
}

\author{
J.D. Vienna, et. al.
}

February 2014

\section{Idaho National Laboratory \\ Idaho Falls, Idaho 83415}

http://www.inl.gov

\author{
Prepared for the \\ U.S. Department of Energy \\ Office of Nuclear Energy \\ Under DOE Idaho Operations Office \\ Contract DE-AC07-05ID14517
}




\section{Closed Fuel Cycle Waste Treatment Strategy}

\section{Fuel Cycle Research \& Development}

Prepared for U.S. Department of Energy Materials Recovery and Waste Forms Campaign

Compiled By: J.D. Vienna (PNNL)

Contributors: E.D. Collins (ORNL), J.V. Crum (PNNL), W.L. Ebert (ANL),

S.M. Frank (INL), T.G. Garn (INL),

D. Gombert (Deceased), R. Jones (SRNL),

R.T. Jubin (ORNL), V.C. Maio (INL), J.C. Marra (SRNL), J. Matyas (PNNL), T.M. Nenoff (SNL), B.J. Riley (PNNL), G.J. Sevigny (PNNL), N.R. Soelberg (INL), D.M. Strachan (Retired), P.K. Thallapally (PNNL), J.H. Westsik (PNNL)

February 27, 2015

FCRD-MRWFD-2015-000674, Rev. 0 


\section{DISCLAIMER}

This information was prepared as an account of work sponsored by an agency of the U.S. Government. Neither the U.S. Government nor any agency thereof, nor any of their employees, makes any warranty, expressed or implied, or assumes any legal liability or responsibility for the accuracy, completeness, or usefulness, of any information, apparatus, product, or process disclosed, or represents that its use would not infringe privately owned rights. References herein to any specific commercial product, process, or service by trade name, trade mark, manufacturer, or otherwise, does not necessarily constitute or imply its endorsement, recommendation, or favoring by the U.S. Government or any agency thereof. The views and opinions of authors expressed herein do not necessarily state or reflect those of the U.S. Government or any agency thereof. 


\begin{abstract}
This study is aimed at evaluating the existing waste management approaches for nuclear fuel cycle facilities in comparison to the objectives of implementing an advanced fuel cycle in the U.S. under current legal, regulatory, and logistical constructs. The study begins with the Global Nuclear Energy Partnership (GNEP) Integrated Waste Management Strategy (IWMS) (Gombert et al. 2008) as a general strategy and associated Waste Treatment Baseline Study (WTBS) (Gombert et al. 2007). The tenets of the IWMS are equally valid to the current waste management study. However, the flowsheet details have changed significantly from those considered under GNEP. In addition, significant additional waste management technology development has occurred since the GNEP waste management studies were performed. This study updates the information found in the WTBS, summarizes the results of more recent technology development efforts, and describes waste management approaches as they apply to a representative full recycle reprocessing flowsheet. Many of the waste management technologies discussed also apply to other potential flowsheets that involve reprocessing. These applications are occasionally discussed where the data are more readily available.

The report summarizes the waste arising from aqueous reprocessing of a typical light-water reactor (LWR) fuel to separate actinides for use in fabricating metal sodium fast reactor (SFR) fuel and from electrochemical reprocessing of the metal SFR fuel to separate actinides for recycle back into the SFR in the form of metal fuel. The primary streams considered and the recommended waste forms include:
\end{abstract}

- Tritium separated from either a low volume gas stream or a high volume water stream. The recommended waste form is low-water cement in high integrity containers (HICs).

- Iodine-129 separated from off-gas streams in aqueous processing. There are a range of potentially suitable waste forms. As a reference case, a glass composite material (GCM) formed by the encapsulation of the silver Mordenite $(\mathrm{AgZ})$ getter material in a low-temperature glass is assumed. A number of alternatives with distinct advantages are also considered including a fused silica waste form with encapsulated nano-sized AgI crystals.

- Carbon-14 separated from LWR fuel treatment off-gases and immobilized as a $\mathrm{CaCO}_{3}$ in a cement waste form.

- Krypton-85 separated from LWR and SFR fuel treatment off-gases and stored as a compressed gas.

- An aqueous reprocessing high-level waste (HLW) raffinate waste which is immobilized by the vitrification process in one of three forms: a single phase borosilicate glass, a borosilicate based glass ceramic, or a multi-phased titanate ceramic [e.g., synthetic rock (Synroc)].

- An undissolved solids (UDS) fraction from aqueous reprocessing of LWR fuel that is either included in the borosilicate HLW glass or is immobilized in the form of a metal alloy in the case of glass ceramics or titanate ceramics.

- Zirconium-based LWR fuel cladding hulls and stainless steel (SS) fuel assembly hardware that are washed and super-compacted for disposal or as an alternative with high promise for the purification and reuse (or disposal as low-level waste, LLW) of Zr by reactive gas separations.

- Electrochemical process salt HLW which is incorporated into a glass bonded Sodalite waste form known as the ceramic waste form (CWF).

- Electrochemical process UDS and SS cladding hulls which are melted into an iron based alloy waste form.

Mass and volume estimates for each of the recommended waste forms based on the source terms from a representative flowsheet are reported. 
In addition to the above listed primary waste streams, a range of secondary process wastes are generated by aqueous reprocessing of LWR fuel, metal SFR fuel fabrication, and electrochemical reprocessing of SFR fuel. These secondary wastes have been summarized and volumes estimated by type and classification.

The important waste management data gaps and research needs have been summarized for each primary waste stream and selected waste process. 


\section{CONTENTS}

ABSTRACT III

ABBREVIATIONS AND ACRONYMS XI

1. PROCESS FLOWSHEET AND WASTE STREAM DEFINITION ............................................ 1

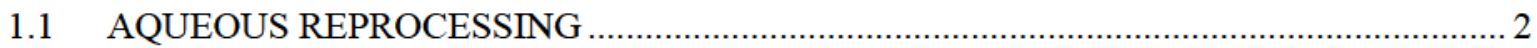

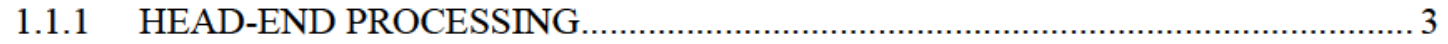

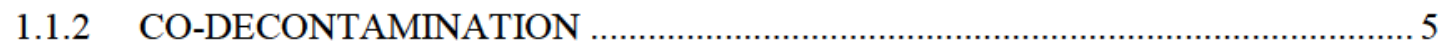

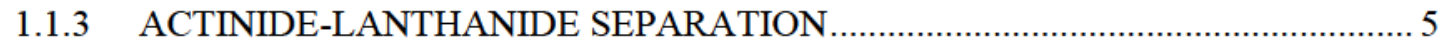

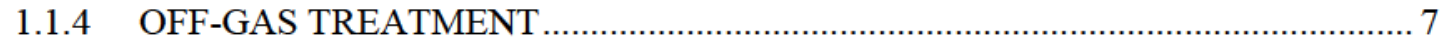

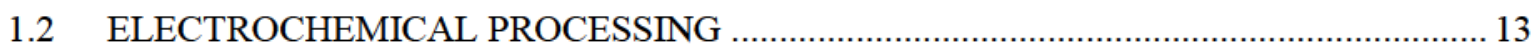

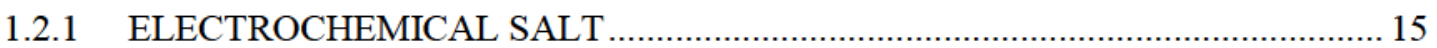

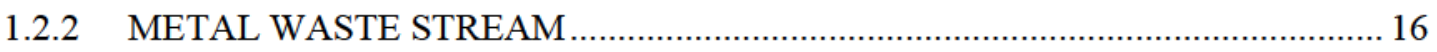

1.2.3 ELECTROCHEMICAL PROCESS OFF-GAS ................................................. 18

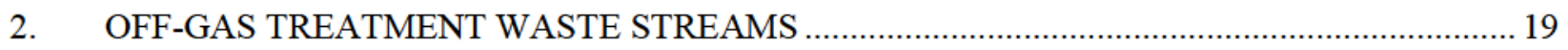

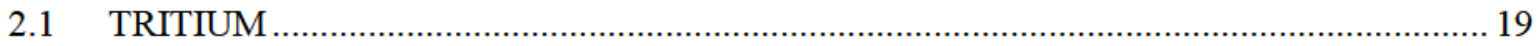

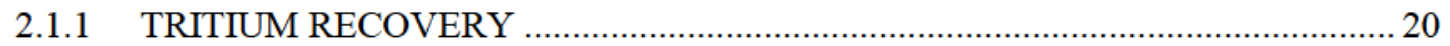

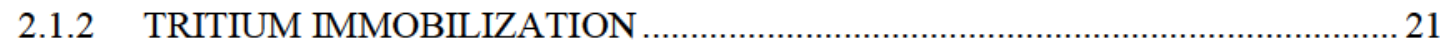

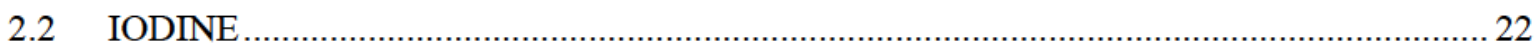

2.2.1 IODINE SEPARATIONS TECHNOLOGIES …............................................. 22

2.2.2 IODINE WASTE FORMS ....................................................................... 27

$2.3 \quad$ KRYPTON

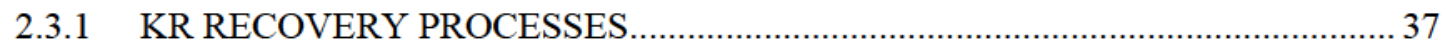

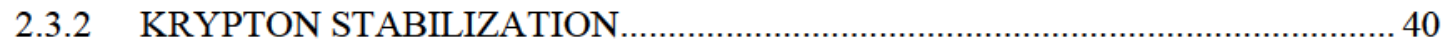

2.4 CARBON-14

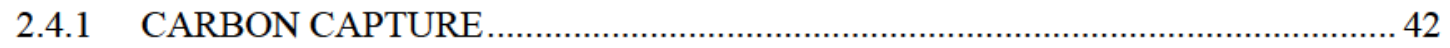

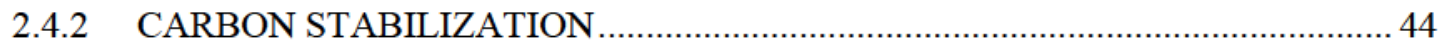

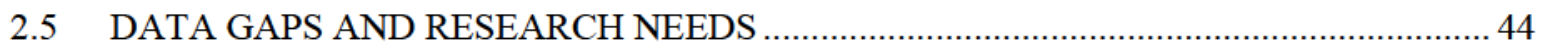

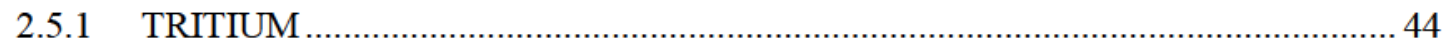

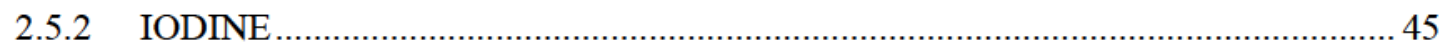

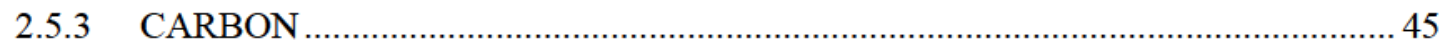

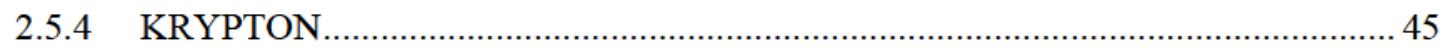

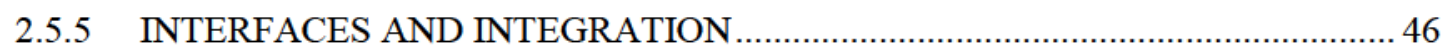

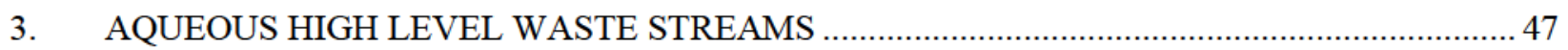

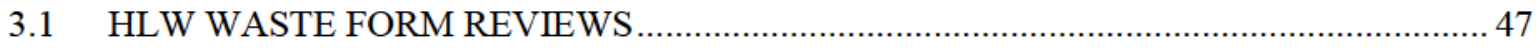

3.1.1 GNEP HLW WASTE FORM RECOMMENDATIONS...................................... 49

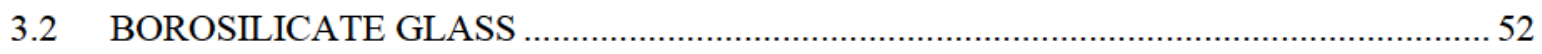

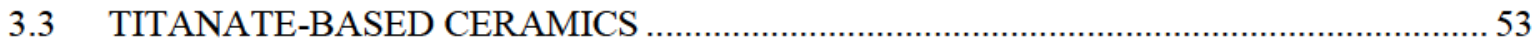

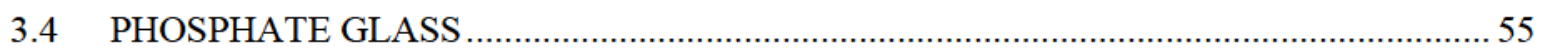

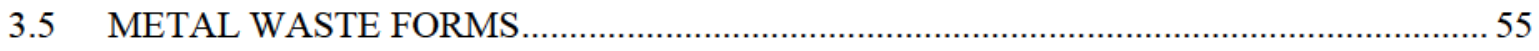

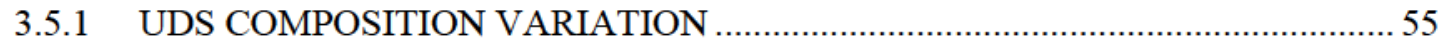

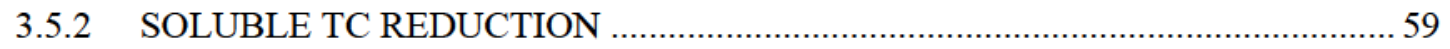

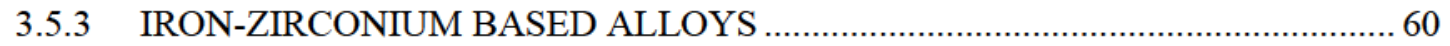

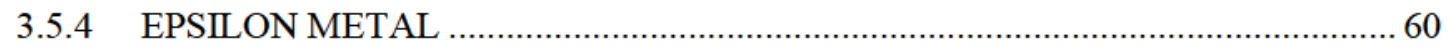




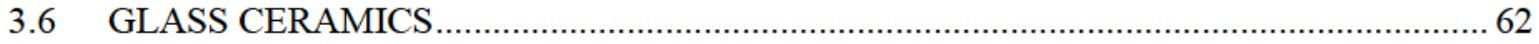

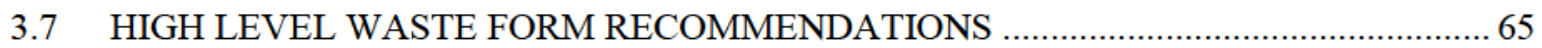

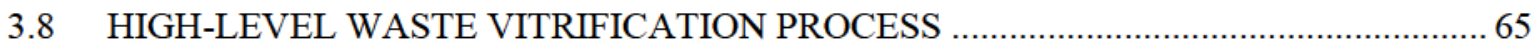

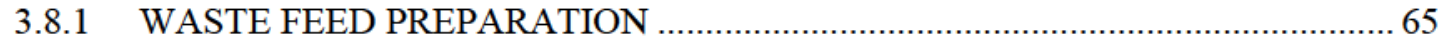

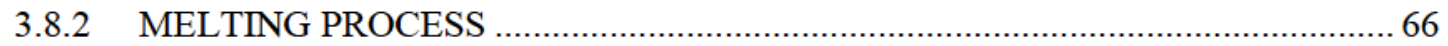

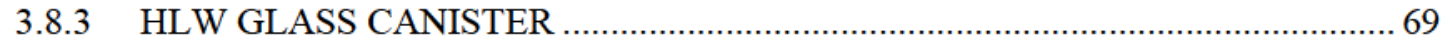

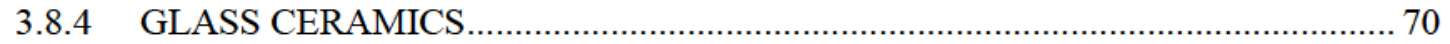

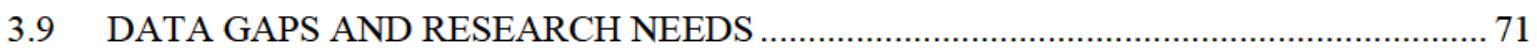

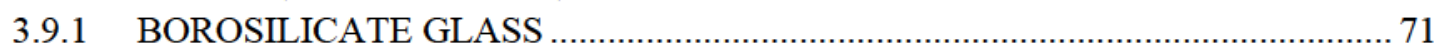

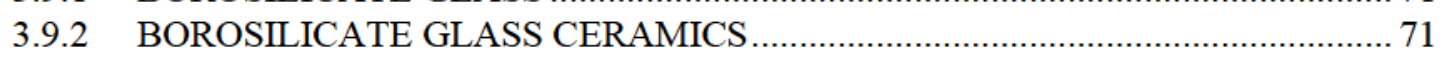

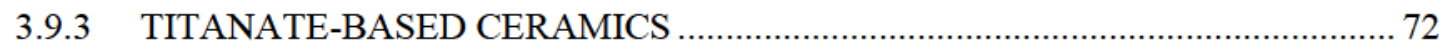

3.9.4 METAL WASTE FORMS FOR UDS AND TC …….......................................... 72

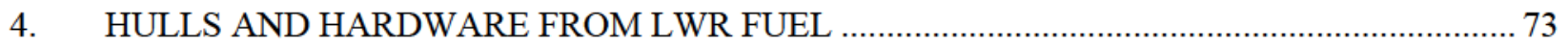

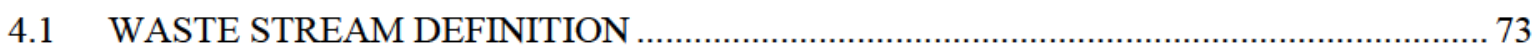

4.2 MANAGEMENT APPROACHES FOR HULLS AND HARDWARE............................... 74

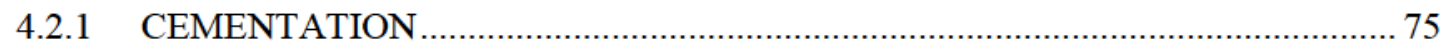

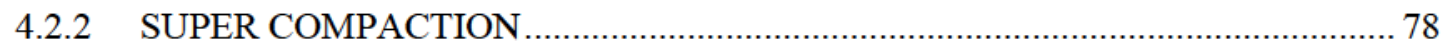

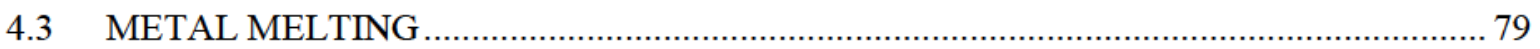

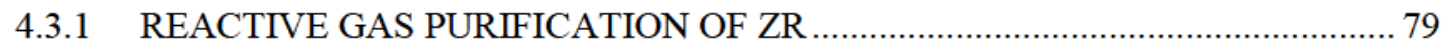

4.4 HULLS AND HARDWARE MANAGEMENT RECOMMENDATION ............................ 81

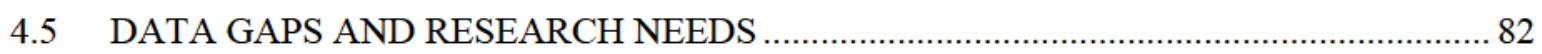

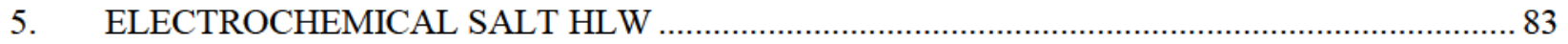

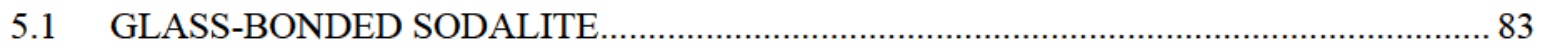

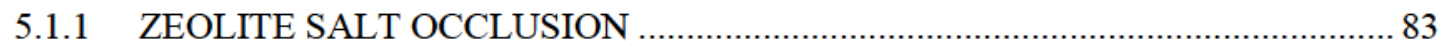

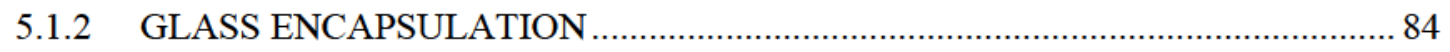

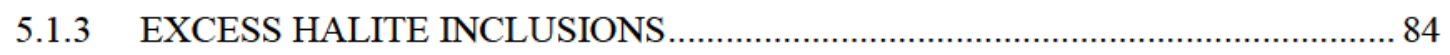

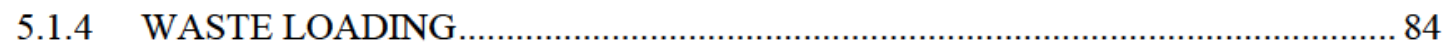

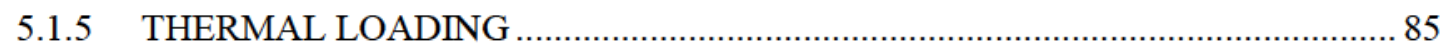

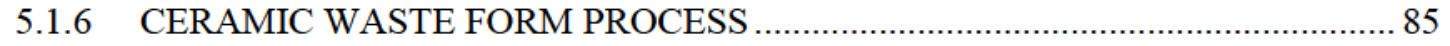

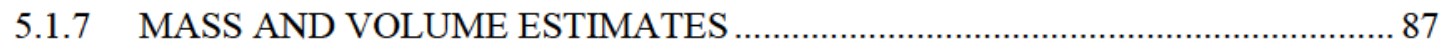

5.2 ALTERNATIVE WASTE FORMS FOR IMMOBILIZATION OF SALT

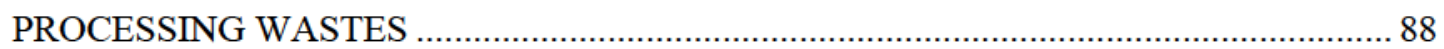

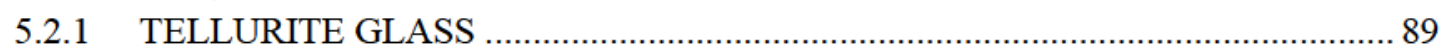

5.2.2 SOLUTION-BASED APPROACHES FOR MAKING SODALITE......................... 89

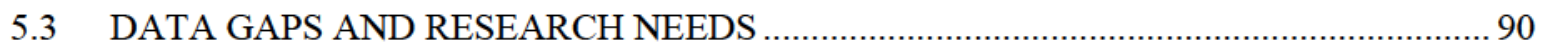

6. ELECTROCHEMICAL UNDISSOLVED SOLIDS AND HULLS …........................................ 91

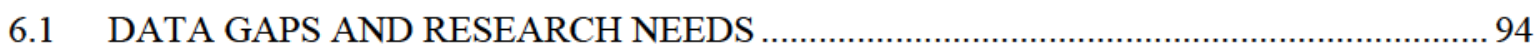

7. TRITIUM REMOVAL AND ENRICHMENT TECHNOLOGIES .............................................. 95

7.1 METHOD FOR ENRICHMENT OF TRITIUM IN WASTE WATER …......................... 96

7.1.1 COMBINED ELECTROLYSIS AND CATALYTIC EXCHANGE ........................96

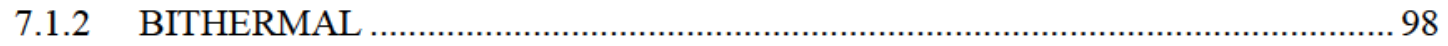

7.1.3 WATER DISTILLATION AND RECTIFICATION ……................................. 98

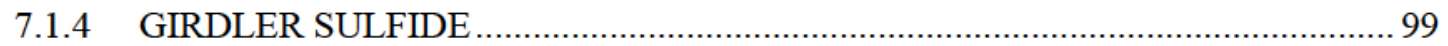

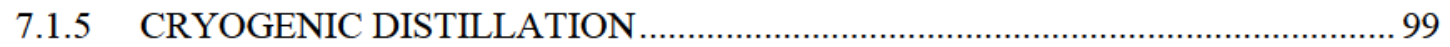




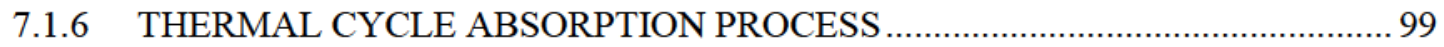

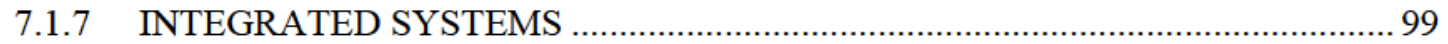

7.1.8 SUMMARY AND RECOMMENDATIONS ...................................................... 100

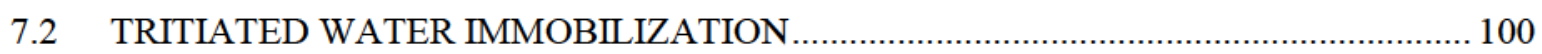

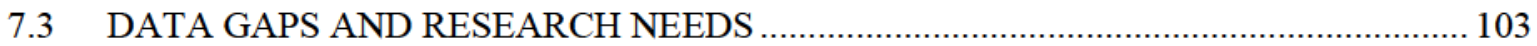

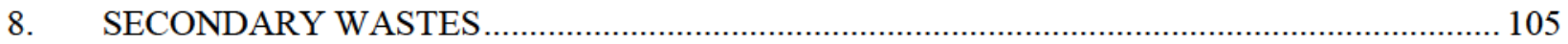

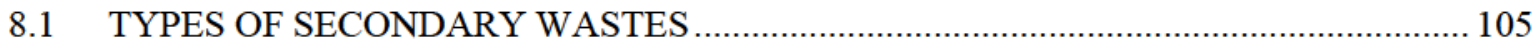

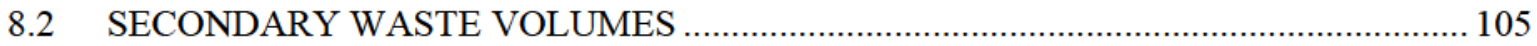

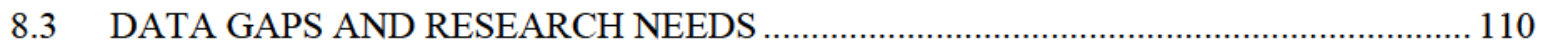

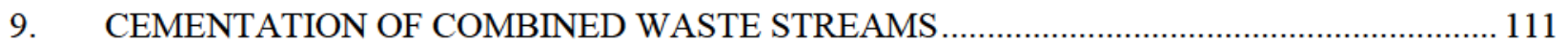

9.1 DATA GAPS AND RESEARCH NEEDS ….............................................................. 112

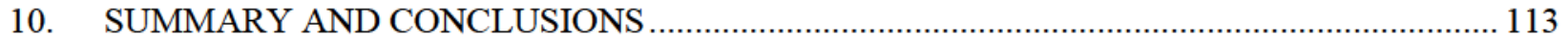

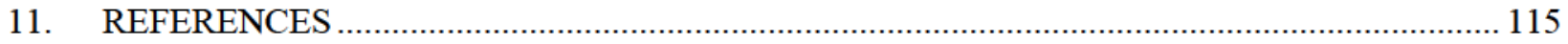




\section{FIGURES}

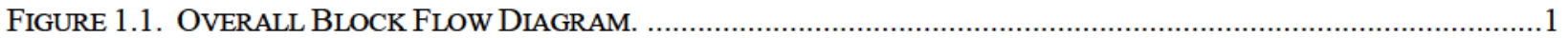

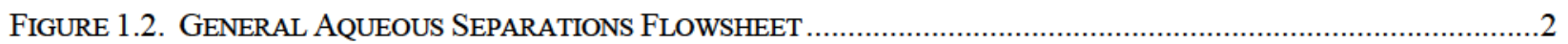

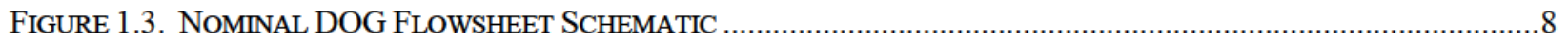

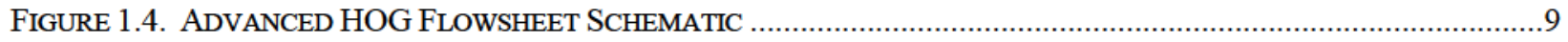

FiguRE 1.5. NOMINAL VeSSEL VeNTILATION OfF-GAS TREATMENT PROCESS SCHEMATIC........................................10

FigURE 1.6. NOMINAL MELTER OFF-GAS TREATMENT SYSTEM.................................................................... 12

FIGURE 1.7. GENERAL ELECTROCHEMICAL SEPARATIONS FLOWSHEET …….............................................................13

Figure 2.1. CONCENTRATION OF ${ }^{3} \mathrm{H}$ IN TYPICAL $50 \mathrm{GWD} / \mathrm{TU}$ PWR FUEL AS A FUNCTION OF TIME FROM Discharge.

FigURE 2.2. SENSITIVITY OF PEAK ANNUAL DOSE FROM ${ }^{129}$ I To WASTE FORM FRACTIONAL DEGRADATION RATE

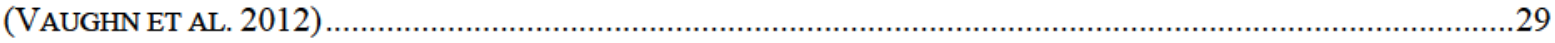

FigURE 2.3. AgIZ TREATMENT BOX FLOW DiAGRAM FoR THE REFERENCE FLOWSHEET .........................................35

FigURE 2.4. AgAERo TREATMENT BOX FLOW DIAGRAM FOR THE ADVANCED FLOWSHEET .....................................36

FigURE 3.1. COMPARISON OF WASTE FORM VOLUME (A) AND COST (B) FOR DIFFERENT COMBINED WASTE STREAMS

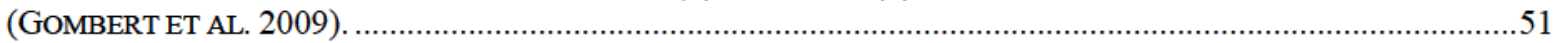

FigURE 3.2. THE UDS COMPOSITIONS OF VARIOUS SEGMENTS OF IRRADIATED NUCLEAR FuELS, AS PERCENTAGE OF

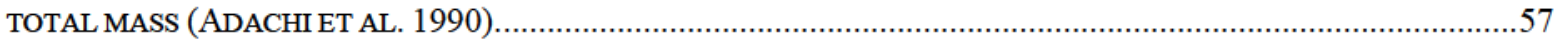

FigURE 3.3. RESUlTS OF ELECTROCHEMICAL TESTS WITH ALLOY EWF-1 IN ACIDIC BRINE....................................62

FIGURE 3.4. COMPARISON OF WASTE LOADINGS BETWEEN GLASS AND GLASS CERAMICS. ......................................63

Figure 3.5. Phase Formation as a FUNCTION OF COOLING RATE (IN TIMES OF EXPECTED NATURAL CANISTER

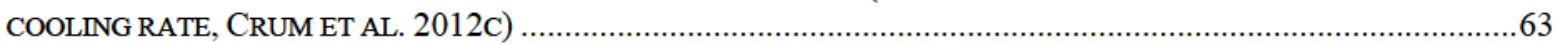

Figure 3.6. Viscosity of Glass CERAMics MELT AS A FUnCTION OF INVERSE TEMPERATURE (CRUM ET AL. 2014).

.

FigURE 3.7. MODEL FOR PHASE CHANGE IN MODEL GLASS CERAMIC (CRUM ET AL. 2014) .......................................64

FIGURE 4.1. SCHEMATIC OF PROCESS OPTIONS FOR HULLS AND HARDWARE FROM (IAEA 1985)............................75

FIGURE 4.2. SCHEMATIC OF IN-DRUM MIXING (OJOVAN AND LEE 2005) ...............................................................76

FigURE 4.3. EXAMPLES OF COMPOSITE CEMENT WASTE FORMS FABRICATED AT SELLAFIELD. WASTE IN (A) IS COMPACTED ILW SOlDS, IN (B) IS MAgNOX (Mg Alloy) Fuel CladDING SWARF AND IN (C) Is ZIRCALOY CLADDING HULLS FROM UOX FUEL

Figure 4.4. Example Metal Waste Form (a) Compaction Untt, (B) Puck, and (c) Cross-Section of UC-C

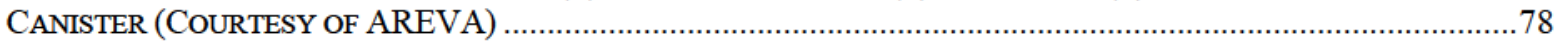

FigURE 4.5. PROCESS FLOW DIAGRAM FOR ZIRCONIUM RECOVERY CHLORINATION PROCESS.................................80

Figure 4.6. POTENTIAL INSERTION OF PURIFIED RECYCLE ZIRCONIUM TETRACHLORIDE INTO THE PROCESS FOR

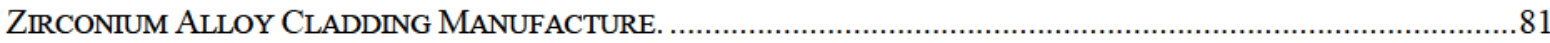

FIGURE 5.1. RENDERED MODEL OF THE CWF CONTAINER, FROM MORRISON ET AL. (2010) ..................................87

FiguRE 5.2. EXAMPLE CWF RELATED PROCESS COST AS A FUNCTION OF IMPURITY CONTENT (FOR A 20 THM

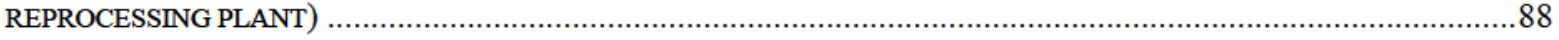

FiguRE 6.1. ZR-Fe PHASE DiAGRAM BASED ON (ARIAS 1988; MCDEAVITT ET AL. 1998) ......................................92

FigURE 6.2. PHOTOGRAPH OF METAL WASTE FoRM SAMPLE, FROM (EBERT 2005) .............................................92

Figure 6.3. MiCROSTRUCTURES OF (A) 316SS-15ZR-10U ALLOY SHOWING STEEL AND ZRFE 2 INTERMETALLIC PHASES With BRighter AREAS HAVING High U CONCENTRATION AND (B) HT-9SS-2ZR-5U WITH THE SAME FE-ZR-U INTERMETALLIC PHASES (OLSON 2012) …….........................................................................92

FIGURE 6.4. SEM PHOTOMICROGRAPHS OF SURFACES OF (A) 75SS-15ZR-0NM-10U ALLOY REACTED IN ACIDIC SOLUTION SHOWING PREFERENTIAL DiSSOLUTION OF FE-ZR-U INTERMETALLIC AND (B) 60SS-12ZR-26NM-2U ALLOY REACTED UNDER THE SAME CONDITIONS WITH No VISIBLE CORROSION. ...........................................93

FIGURE 7.1. EXAMPLE CECE PROCESS SCHEMATIC (FROM WILLIS ET AL. 2013) ...................................................97

FIGURE 7.2. PHOTO OF THE MOSS UNIT WITH “LOST-STIRRER" TO BE UTLIZED AT ROSSENDORF (GESSER ET AL. 2000) 


\section{TABLES}

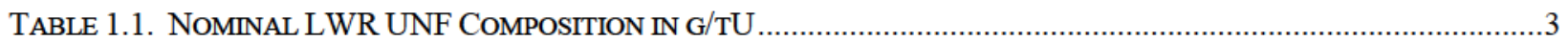

TABLE 1.2. ISOTOPE PARTITIONING IN STANDARD AIR TPT (JUBIN ET AL. 2010). .....................................................

TABLE 1.3. ESTIMATED COMPOSITION OF WASHED LWR HULLS FOR WASTE MANAGEMENT ...................................

TABLE 1.4. SuMmary OF THE ASSUMEd UDS SPLIT FROM THE DiSSOLVER SOlUTION AND THE RESUlting UDS

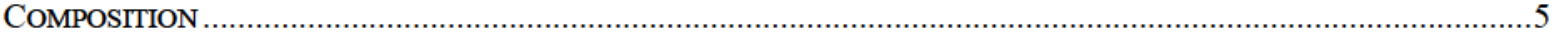

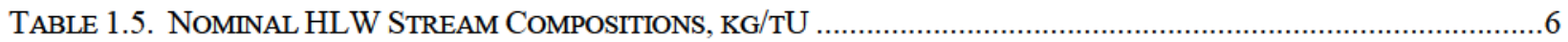

TABLE 1.6. ESTIMATED DFS FOR 5- AND 50-Y COOLED PWR UOX FUEL REPROCESSED IN A 1000 TU/Y PLANT ..........7

TABLE 1.7. NOMINAL COMBINED GAS COMPOSITION ENTERING THE IODINE BED.....................................................

TABLE 1.8. COMPOSITION OF HOG COMPONENTS AT VARIOUS STAGES, KG/TU REPROCESSED..................................10

TABLE 1.9. COMPARISON OF DOG AND VOG FLOWS IN KG/TU PROCESSED ..........................................................11

TABLE 1.10. EXAMPLES MOG TREATMENT COMPONENTS AND PURPOSES ...............................................................12

TABLE 1.11. EXAMPLE VITRIFICATION SYSTEM OFF-GAS FLOWS (KG/TU PROCESSED) ............................................13

TABLE 1.12. NOMINAL COMPOSITION FOR USED SFR METAL U/PU/ZR FUEL, 0.75 CONVERSION RATIO, 99.6

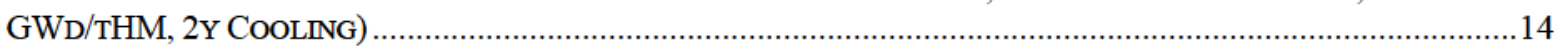

TABLE 1.13. EXAMPLE SALT COMPOSITIONS (MASS\% COMPONENT AND TOTAL KG/THM) .....................................16

TABLE 1.14. FreE ENERGIES OF Formation OF CHLORDES $\left(-\Delta \mathrm{G}_{0}\right.$, KCAL/G-EQ AT $\left.500^{\circ} \mathrm{C}\right)$ (FROM NAS 1995) ..........17

TABLE 1.15. NOMINAL METAL WASTE STREAM COMPOSITION, KG/THM........................................................... 17

TABLE 2.1. TRITIUM RECOVERY STEP: MOLECULAR SIEVES (MS3A) .................................................................22

TABLE 2.2. RANGES OF ESTIMATED IODINE PARTITIONING BETWEEN VARIOUS OFF-GAS STREAMS .........................22

TABLE 2.3. IODINE RECOVERY PROCESS COMPARISON ……..............................................................................2

TABLE 2.4. SUMMARY OF KRYPTON RECOVERY PROCESSES.................................................................................40

TABLE 2.5. SUMMARY OF KRYPTON STABILIZATION METHODS..........................................................................4

TABLE 2.6. SUMMARY OF CARBON RECOVERY PROCESSES .....................................................................................43

TABLE 3.1. CANDIDATE WASTE FORMS CONSIDERED FOR IMMOBLIZATION OF HLW FOR DISPOSAL

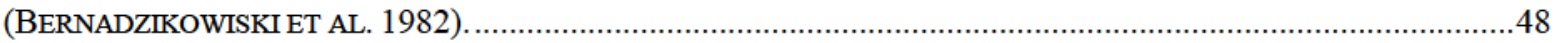

TABLE 3.2. GLASS WASTE FORMS USED INTERNATIONALLY FOR IMMOBLIZATION OF HLW..................................49

TABLE 3.3. SuMMARY OF WASTE FORMS FOR THREE PRIMARY CASES CONSIDERED BY GOMBERT ET AL. 2009) ......50

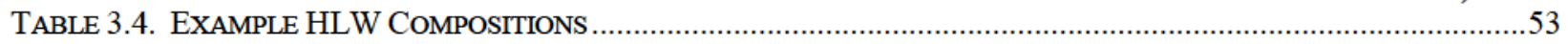

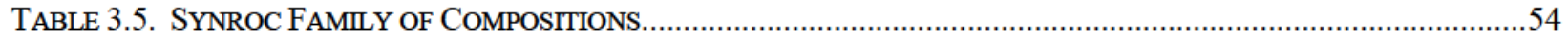

TABLE 3.6. RETENTION OF ELEMENTS OF INTEREST IN UDS, AS A PERCENT OF INVENTORY ...................................58

TABLE 3.7. SuMMARY OF WASTE, FRIT AND GLASS COMPOSITIONS (MASS\% OF OXIDES) ……...............................66

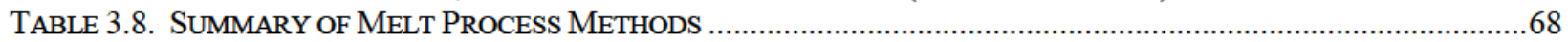

TABLE 3.9. MAXIMUM MELTER FEED CONCENTRATIONS, GRAMS OF GLASS PER LITER OF MELTER FEED...................69

TABLE 3.10. Summary OF EVAlUATED HLW CANISTER OptIONS FOR GLASS FOR 1000 TU/Y REPROCESSING PLANT

TABLE 3.11. SUMMARY OF WASTE, FRIT, AND GLASS CERAMIC COMPOSITIONS (MASS\%).....................................70

TABLE 3.12. SUMMARY OF EVALUATED HLW CANISTER OPTIONS FOR GLASS CERAMIC VITRIFICATION ..................71

TABle 3.13. Summary of Glass Ceramic Production Rate and Melter SCAles (assuming a Single line

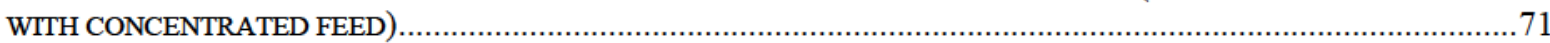

TABLE 4.1. EXAMPLE LIST OF NON-FUEL PARTS IN TYPICAL UNF ASSEMBLIES (OCRWM 2008)...........................73

TABLE 4.2. REPRESENTATIVE COMPOSITIONS OF STAINLESS STEELS AND ZIRCALOYS, MASS\% …............................74

TABLE 5.1. CERAMIC WASTE FORM MASS AND VOLUME FOR 20 THM/Y REPROCESSING .....................................8 88

TABLE 7.1. TRITIUM SOURCE TERMS FOR 50 GWD/TU PWR FUEL....................................................................96

TABLE 7.2. TRITIUM REMOVAL TEChNOLOGIES IN COMMERCIAL USE - OPERATING AND PROPOSED FACILITIES..... 100

TABLE 7.3. TRITIUM CEMENT MASSES AND VOLUME SuMMARIES ................................................................102

TABLE 8.1. SUMMARY OF SECONDARY WASTE VOLUMES FOR FUEL RECYCLING, MOX FUEL FABRICATION AND FAST REACTOR FUEL FABRICATION (FROM JONES AND CARTER 2013) ..........................................................107

TABLE 8.2. ESTIMATED SECONDARY WASTE VOLUMES $\left(\mathrm{M}^{3}\right)$ BY WASTE CLASSIFICATION FOR $800 \mathrm{TU} / \mathrm{Y}$ RECYCLING

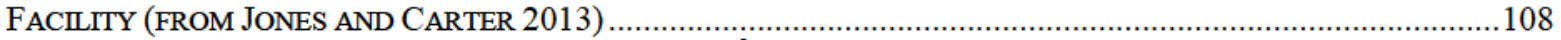

TABLE 8.3. ESTIMATED SECONDARY WASTE VOLUMES $\left(\mathrm{M}^{3}\right)$ BY FUNCTIONAL AREA FOR 800 TU/Y RECYCLING

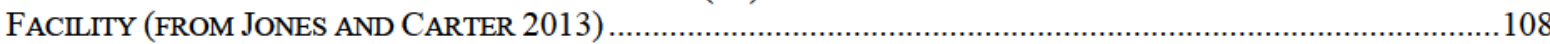

TABLE 8.4. ESTIMATED SECONDARY WASTE VOLUMES $\left(\mathrm{M}^{3}\right)$ FOR MOX FUEL FABRICATION (FROM JONES AND CARTER 2013) 
TABLE 8.5. ESTIMATED SECONDARY WASTE VOLUMES $\left(\mathrm{M}^{3}\right)$ FOR FAST REACTOR FUEL FABRiCATION (FROM JONES AND CARTER 2013)

TABLE 8.6. Estimated USED Fuel REPROCESSING SeCONDARY WASTE TOTAL PACKAGEd VOlume REDUCTIONS That Could Be Cost-EFfective Considering Total Treatment, Storage, Transportation, and DisPOSAL COSTS.

TABLE 9.1. High-SOdA CEMENT Blend Formulations, DRY MASS\%

TABLE 9.2. SUMMARY OF CEMENT WASTE Form VOlUME AND MASS

TABLE 10.1. ESTIMATED REPROCESSING WASTE MASSES AND VOLUMES FOR A $1000 \mathrm{TU} / \mathrm{Y}$ AQUEOUS USED FUEL REPROCESSING FACILITY ( $50 \mathrm{GW} / \mathrm{TU}$ BURNUP LWR FUEL).

TABLE 10.2. ESTIMATED REPROCESSING WASTE MASSES AND VOLUMES FOR A 20 TU/Y ELECTROCHEMICAL USED FUEL REPROCESSING FACILITY (100 GW/THM BURNUP SFR FUEL). 


\section{ABBREVIATIONS AND ACRONYMS}

$\begin{array}{ll}\text { ACC } & \text { Atelier de Compactage des Coques } \\ \text { AFCF } & \text { Advanced Fuel Cycle Facility } \\ \text { AgAero } & \text { silver functionalized silica aerogel } \\ \text { AgX } & \text { silver-exchanged Faujasite } \\ \text { AgZ } & \text { silver-exchanged Mordenite } \\ \text { AHA } & \text { acetohydroxamic acid } \\ \text { ALS } & \text { actinide-lanthanide separations } \\ \text { AMUSE } & \text { Argonne model for universal solvent extraction } \\ \text { ANDRA } & \text { Agence Nationale Pour la Gestion des Déchets Radioactifs } \\ \text { ANL } & \text { Argonne National Laboratory } \\ \text { AVLIS } & \text { atomic vapor laser isotope separation } \\ \text { BFS } & \text { blast furnace slag } \\ \text { BNFP } & \text { Barnwell Nuclear Fuel Plant } \\ \text { BWR } & \text { boiling water reactor } \\ \text { CCIM } & \text { cold crucible induction melter } \\ \text { CETE } & \text { coupled end-to-end demonstration } \\ \text { CECE } & \text { combined electrolysis catalytic exchange } \\ \text { CFR } & \text { Code of Federal Regulations } \\ \text { CFTC } & \text { Consolidated Fuel Treatment Center } \\ \text { CMPO } & \text { octyl(phenyl)-N,N-diisobutylcarbamoylmethylphosphine oxide } \\ \text { CS/SR } & \text { Cs, Sr, Ba, and Rb waste stream } \\ \text { DF } & \text { decontamination factor } \\ \text { DOE-NE } & \text { U.S. Department of Energy, Office of Nuclear Energy } \\ \text { DOG } & \text { dissolver off-gas (treatment) } \\ \text { DTPA } & \text { diethylenetriaminepentaacetic acid } \\ \text { DU } & \text { depleted uranium } \\ \text { EAS } & \text { Engineering Alternative Studies } \\ \text { EBR II } & \text { Experimental Breeder Reactor II } \\ \text { Echem } & \text { electrochemical processing } \\ \text { EPA } & \text { Environmental Protection Agency } \\ \text { ER } & \text { electrorefiner } \\ \text { EVS } & \text { ejector venturi scrubber } \\ \text { FA } & \text { fly ash } \\ \text { FCRD } & \text { Fuel Cycle Research and Development (Program) } \\ \text { FOEAS } & \text { Follow-On Engineering Alternative Studies } \\ \text { FR } & \text { fast reactor } \\ \text { FP } & \text { fission products } \\ \text { GCM } & \text { glass composite materials } \\ \text { GNEP } & \text { Global Nuclear Energy Partnership } \\ \text { GTCC } & \text { greater-than-Class-C } \\ \text { GWd } & \text { gigawatt days } \\ \text { HDEHP } & \text { bis-(2-ethylhexyl) phosphoric acid } \\ \text { HEDTA } & \text { N-(2-hydroxyethyl)ethylenediamine-N,N',N'-triacetic acid } \\ \text { HEH[EHP] } & \text { 2-ethylhexylphosphonic acid mono-2-ethylhexyl ester } \\ \text { HEME } & \text { high efficiency mist eliminator } \\ \text { HEPA } & \text { high efficiency particulate air } \\ \text { HIC } & \text { high-integrity container } \\ \text { HIP } & \text { hot isostatic press } \\ \text { HLW } & \text { high-level waste } \\ & \end{array}$




\begin{tabular}{|c|c|}
\hline HOG & heat-end off-gas (treatment) \\
\hline HTO & tritiated-proton oxide (tritiated water, $\left[{ }^{3} \mathrm{H},{ }^{2} \mathrm{H},{ }^{1} \mathrm{H}\right]_{2} \mathrm{O}$ ) \\
\hline HUP & hot uniaxial press \\
\hline HWIM & hot-walled induction melter \\
\hline HWRM & hot-walled resistance heated melter \\
\hline $\mathrm{HZ}$ & hydrogen Mordenite \\
\hline IAEA & International Atomic Energy Agency \\
\hline $\mathrm{ICM}$ & in-can melter \\
\hline IFR & Integral Fast Reactor \\
\hline ILW & intermediate-level waste \\
\hline INEL & Idaho National Engineering Laboratory \\
\hline INL & Idaho National Laboratory \\
\hline JHCM & joule-heated ceramic melter \\
\hline LAW & low-activity waste \\
\hline LEU & low-enriched uranium \\
\hline LFCM & liquid-fed Joule-heated ceramic melter \\
\hline LLW & low-level waste \\
\hline LMFBR & liquid-metal fast breeder reactor \\
\hline $\mathrm{LN}$ & lanthanide elements \\
\hline LNFP & lanthanide element fission product waste stream \\
\hline LWR & light water reactor \\
\hline MA & minor actinides (primarily $\mathrm{Np}, \mathrm{Am}, \mathrm{Cm}$ ) \\
\hline MC\&A & materials control and accountability \\
\hline MDD & modified direct denitration \\
\hline MEI & maximum exposed individual \\
\hline MOF & metal organic framework \\
\hline MOG & melter off-gas (treatment) \\
\hline MOX & mixed oxide $[\mathrm{Pu}, \mathrm{U}] \mathrm{O}_{2}$ (fuel) \\
\hline MPC & multi-purpose canister \\
\hline MS3A & molecular sieve $3 \mathrm{~A}$ \\
\hline $\mathrm{NO}_{\mathrm{X}}$ & nitrogen oxides \\
\hline $\mathrm{OPC}$ & ordinary portland cement \\
\hline ORIGEN & Oak Ridge Isotope Generator \\
\hline ORNL & Oak Ridge National Laboratory \\
\hline PNNL & Pacific Northwest National Laboratory \\
\hline PUREX & plutonium uranium reduction extraction \\
\hline PWR & pressurized water reactor \\
\hline SAS & steam atomized scrubber \\
\hline $\mathrm{SCO}$ & selective catalytic oxidizer \\
\hline SCR & selective catalytic reducer \\
\hline SMF & sintered metal filter \\
\hline SFR & sodium fast reactor \\
\hline SPS & spark plasma sintering \\
\hline SRNL & Savannah River National Laboratory \\
\hline SRS & Savannah River Site \\
\hline SWF & separation and waste forms \\
\hline TALSPEAK & $\begin{array}{l}\text { trivalent actinide-lanthanide separations by phosphorus-reagent extraction from aqueous } \\
\text { komplexes }\end{array}$ \\
\hline TBP & tributyl phosphate \\
\hline tHM & metric tons initial heavy metal (= tU for UOX fuel) \\
\hline THORP & Thermal Oxide Reprocessing Plant \\
\hline
\end{tabular}




$\begin{array}{ll}\mathrm{T}_{\mathrm{L}} & \text { liquidus temperature } \\ \text { TMFP } & \text { transition metal fission product waste stream } \\ \text { TOG } & \text { tritium pretreatment off-gas (treatment) } \\ \text { TPT } & \text { tritium pretreatment } \\ \text { tPu } & \text { metric ton initial plutonium } \\ \text { TRC } & \text { thermal reaction chamber } \\ \text { TRU } & \text { transuranic (waste) } \\ \text { TRUEX } & \text { transuranic extraction } \\ \text { tU } & \text { metric ton initial uranium } \\ \text { UC-C } & \text { universal container for compacted metal waste } \\ \text { UC-V } & \text { universal container for vitrified waste } \\ \text { UDS } & \text { undissolved solids } \\ \text { UFD } & \text { Used Fuel Disposition } \\ \text { UNF } & \text { used nuclear fuel } \\ \text { UOX } & \text { uranium oxide (fuel) } \\ \text { UREX } & \text { uranium extraction } \\ \text { VISION } & \text { Verifiable Fuel Cycle Simulation } \\ \text { VOG } & \text { vessel off-gas (treatment) } \\ \text { WAK } & \text { Karlsruhe Reprocessing Plant (Wiederaufarbeitungsanlage Karlsruhe) } \\ \text { WESP } & \text { wet electrostatic precipitator } \\ \text { WTP } & \text { Hanford Tank Waste Treatment and Immobilization Plant } \\ \text { WVDP } & \text { West Valley Demonstration Project }\end{array}$




\section{PROCESS FLOWSHEET AND WASTE STREAM DEFINITION}

An overall block flow diagram of the full recycle strategy utilized for this study is shown in Figure 1.1. A homogeneous recycle of the uranium (U) and transuranic (TRU) elements resulting from the reprocessing of light-water reactor (LWR) uranium oxide (UOX) fuel is used as feed for advanced metal fuel fabrication. The metal fuel is irradiated in a sodium cooled fast reactor (SFR) and the used fast reactor (FR) fuel is reprocessed electrochemically. The recovered U/TRU from electrochemical separations is recycled to metallic FR fuel. Waste streams from the aqueous and electrochemical (echem) reprocessing are treated and prepared for disposition. Off-gas from the separations and waste processing are also treated.

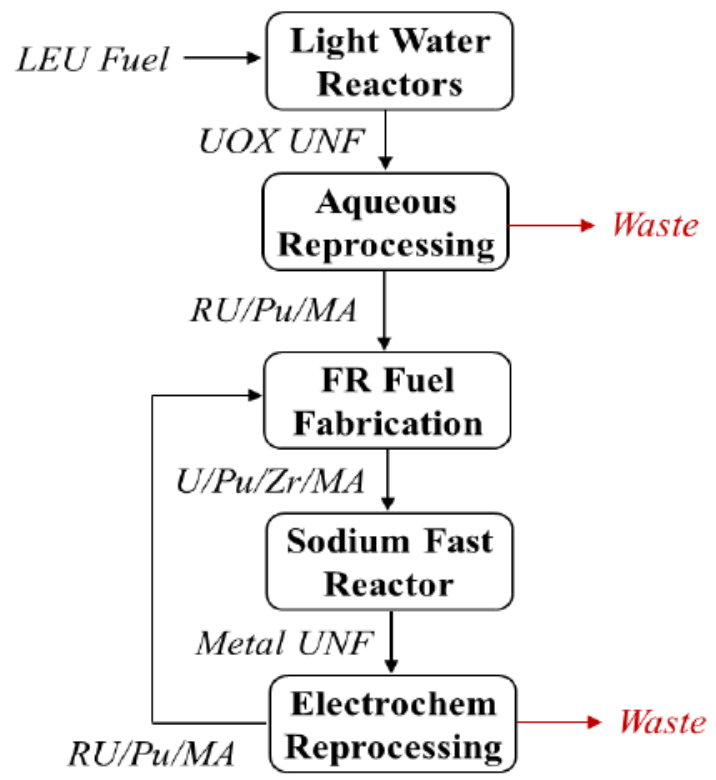

Figure 1.1. Overall Block Flow Diagram.

Waste compositions and masses are estimated using the following assumptions:

1. Nominal annual throughput of 1000 metric tons of initial uranium (tU)/y LWR fuel is processed with aqueous reprocessing and 20 metric tons of initial heavy metal (tHM)/y FR fuel is processed with echem.

2. Used LWR fuel is based on 5\% enriched UOX fuel in Zircaloy-4 cladding irradiated for 50 gigawatt days $(\mathrm{GWd} / \mathrm{tU})$ in a pressurized water reactor (PWR) and cooled for 5 years before reprocessing.

3. Used FR fuel is based on a U, 20 mass $\% \mathrm{Pu}, 10$ mass $\% \mathrm{Zr}$, and minor actinides (MA, primarily $\mathrm{Np}, \mathrm{Am}$, and $\mathrm{Cm}$ ) sodium bonded metallic fuel in HT-9 cladding irradiated for $100 \mathrm{GWd} / \mathrm{tHM}$ in a SFR operating with a conversion ratio of 0.75 and cooled for 2 years before reprocessing.

4. Separation and decontamination efficiencies of:

a. Minimum of $99 \%$ recovery of $\mathrm{U}, \mathrm{Pu}$, and $\mathrm{MA}$, individually, from the used fuel.

b. Minimum of $99 \%$ Separation of actinides from lanthanides (LN).

c. Maximum of $1 \%$ contamination of MA product stream with LN. 


\subsection{Aqueous Reprocessing}

The aqueous reprocessing of UOX fuel is shown schematically in Figure 1.2. The nominal input LWR UNF composition is given in Table 1.1. The fuel is first disassembled and chopped into segments. The fuel is either oxidized and removed from the cladding and then dissolved (in the advanced flowsheet) or directly dissolved from the cladding (in the nominal flowsheet). The solution in which the fuel is dissolved is clarified to remove undissolved solids (UDS). The preceding steps constitute the head-end of the flowsheet. Off-gases from the shear, tritium pretreatment process (TPT, if used), and the dissolver are treated in the head-end off-gas (HOG) treatment system. In the co-decontamination process solvent extraction is used to separate $\mathrm{U}+\mathrm{Pu}+\mathrm{Np}, \mathrm{U}$, and, in the case of the advanced flowsheet, Tc streams. The minor actinides are separated from the coextraction raffinate and the lanthanides in the actinidelanthanide separations $(A L S)$ process with a combination of transuranic extraction (TRUEX) and Trivalent Actinide - Lanthanide Separation by Phosphorous reagent Extraction from Aqueous Komplexes (TALSPEAK). The TRUEX raffinate is combined with the TALSPEAK product and, in the case of the nominal flowsheet, the Tc and UDS to form the high-level waste (HLW) raffinate.

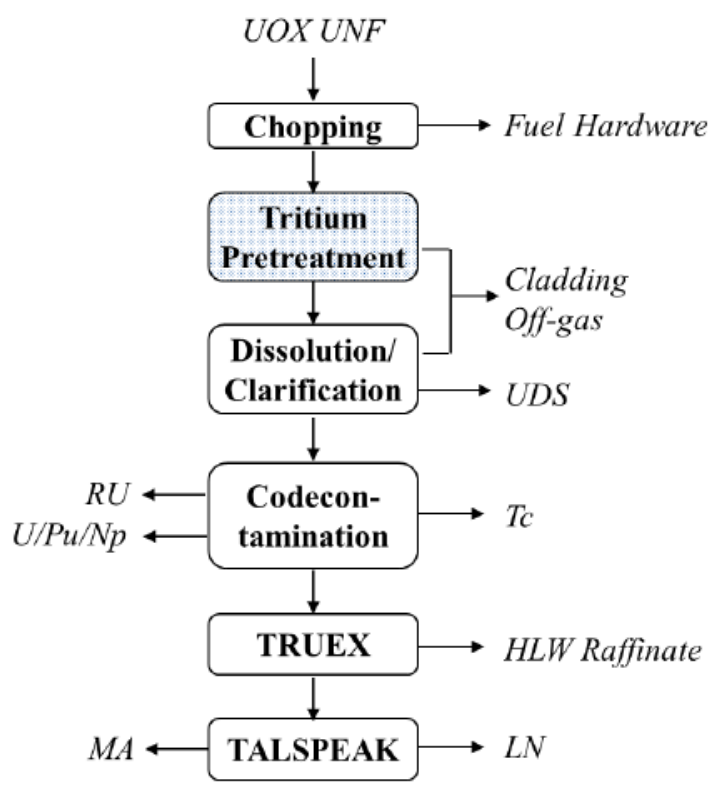

Figure 1.2. General Aqueous Separations Flowsheet 
Table 1.1. Nominal LWR UNF Composition in $\mathrm{g} / \mathrm{tU}$

\begin{tabular}{|c|c|c|c|}
\hline Element & $\mathbf{g} / \mathbf{t U}$ & Element & $\mathbf{g} / \mathbf{t U}$ \\
\hline $\mathbf{A c}$ & $6.42 \times 10^{-8}$ & $\mathrm{Pd}$ & 2350 \\
\hline $\mathbf{A g}$ & 115 & $\mathrm{Pm}$ & 40.6 \\
\hline $\mathbf{A m}$ & 642 & $\mathrm{Pr}$ & 1690 \\
\hline $\mathbf{B a}$ & 2570 & $\mathrm{Pu}$ & $1.17 \times 10^{4}$ \\
\hline${ }^{14} \mathbf{C}$ & 0.3 & $\mathrm{Ra}$ & $2.24 \times 10^{-7}$ \\
\hline $\mathbf{C d}$ & 198 & $\mathrm{Rb}$ & 518 \\
\hline $\mathbf{C e}$ & 3600 & $\mathrm{Rh}$ & 610 \\
\hline $\mathbf{C m}$ & 77 & $\mathrm{Ru}$ & 3470 \\
\hline $\mathbf{C r}$ & 3910 & $\mathrm{Sb}$ & 33 \\
\hline $\mathbf{E u}$ & 253 & $\mathrm{Se}$ & 84.7 \\
\hline $\mathbf{G d}$ & 211 & $\mathrm{Sm}$ & 1254 \\
\hline${ }^{3} \mathbf{H}$ & 0.0646 & $\mathrm{Sn}$ & 140 \\
\hline $\mathbf{I}$ & 357 & $\mathrm{Sr}$ & 1210 \\
\hline $\mathbf{K r}$ & 540 & $\mathrm{Te}$ & 745 \\
\hline $\mathbf{L a}$ & 1850 & $\mathrm{Tc}$ & 1140 \\
\hline $\mathbf{M o}$ & 5060 & $\mathrm{Th}$ & $5.41 \times 10^{-3}$ \\
\hline $\mathbf{N a}$ & 0 & $\mathrm{U}$ & $9.35 \times 10^{5}$ \\
\hline $\mathbf{N b}$ & $4.70 \times 10^{-3}$ & $\mathrm{Xe}$ & 8000 \\
\hline $\mathbf{N d}$ & 6140 & $\mathrm{Y}$ & 676 \\
\hline $\mathbf{N p}$ & 650 & $\mathrm{Zr}(\mathrm{FP})$ & 5370 \\
\hline $\mathbf{O}$ & $1.35 \times 10^{5}$ & $\mathrm{Zy} 4^{\mathrm{a}}$ & $2.54 \times 10^{5}$ \\
\hline $\mathbf{P a}$ & $5.86 \times 10^{-4}$ & $\mathrm{SS}$ & $4.70 \times 10^{3}$ \\
\hline $\mathbf{P b}$ & $1.45 \times 10^{-5}$ & Total & $\mathbf{1 . 4 4 \times 1 0 ^ { 6 }}$ \\
\hline
\end{tabular}

(a) Zy $4=$ Zircaloy- 4 comprised nominally in mass $\%$ of $1.45 \mathrm{Sn}, 0.21 \mathrm{Fe}, 0.1$ $\mathrm{Cr}, 0.056$ other, balance $\mathrm{Zr}$

(b) SS = stainless steel which nominally in mass \% contains 3 304(L), 37 Inconel-718, and $60 \mathrm{CF} 3 \mathrm{M}$ (resulting in an average composition of 47.2 $\mathrm{Fe}, 25.7 \mathrm{Ni}, 19 \mathrm{Cr}, 2.6 \mathrm{Mo}, 1.9 \mathrm{Nb}+\mathrm{Ta}, 1.4 \mathrm{Si}, 1.1 \mathrm{Mn}$, and 1.1 others)

\subsubsection{Head-End Processing}

The head-end treatment steps for UNF processing generally denote the unit operations required to prepare the fuel for solvent extraction. UNF are prepared for dissolution by first shearing the end piece off with a special blade then incrementally shearing the fuel pins into roughly $50-\mathrm{mm}$ segments. In the nominal flowsheet, the fuel meat is dissolved from the fuel segments while still in the cladding. In the advanced flowsheet, a TPT process is used to remove ${ }^{3} \mathrm{H}$ and declad the fuel before it is dissolved. In this flowsheet, the sheared fuel is heated to $500{ }^{\circ} \mathrm{C}$ in dry air to oxidize the $\mathrm{UO}_{2}$ fuel to $\mathrm{U}_{3} \mathrm{O}_{8}$. The volume change during oxidation converts the fuel pellets into a fine powder; ${ }^{3} \mathrm{H}$ is released, as a mixed hydrogen isotope oxide $\left(\left[{ }^{3} \mathrm{H},{ }^{2} \mathrm{H},{ }^{1} \mathrm{H}\right]_{2} \mathrm{O}\right)$ referred to hereafter as HTO. Other isotopes are also partially released in TPT as shown in Table 1.2.

Table 1.2. Isotope Partitioning in Standard Air TPT (Jubin et al. 2010).

\begin{tabular}{|l|l|l|}
\hline Isotope & Percent released & Form \\
\hline${ }^{3} \mathbf{H}$ & $99.9^{(\text {a) }}$ & $\mathrm{HTO}$ \\
\hline${ }^{14} \mathbf{C}$ & 50 & $\mathrm{CO}_{2}$ \\
\hline${ }^{85} \mathbf{K r}$ & 50 & $\mathrm{Kr}$ \\
\hline${ }^{129} \mathbf{I}$ & 0.1 & $\mathrm{I}_{2}$ \\
\hline $\begin{array}{l}\text { (a) } 99.9 \text { percent of } \\
\text { during in the fuel meat released to the off-gas } \\
\text { dur Traction of }{ }^{3} \mathrm{H} \text { in the hulls is unaffected. }\end{array}$ \\
\hline
\end{tabular}


The fuel oxide is dissolved from the hulls in hot $7.3 \underline{\mathrm{M} \mathrm{HNO}} 3 . \mathrm{HNO}_{3}$ is consumed during the dissolution process with a final concentration near $3 \underline{\mathrm{M}}$. Fuel dissolution can be performed in either batch or continuous dissolvers. The fuel hardware and cladding hulls are rinsed to remove nuclear materialcontaining residues. The dissolver solution is subsequently clarified by centrifugation to remove undissolved solids (UDS).

The primary waste streams from head-end processing include the hulls, hardware, and UDS. It is assumed that $0.05 \%$ of the $\mathrm{U}$ and $\mathrm{Pu}, 0.03 \%$ of the other actinides, and $0.2 \%$ of the fission and activation products are carried with the hulls because fuel adheres to the metal surface and they are embedded in the metal surface from alpha recoil ejection from the fuel surface. In addition, it is assumed that $25 \%$ of the tritium resides in the hulls, although this value may vary from 0 to $78 \%$ (Robinson and Jubin 2013). The composition of the washed and contaminated hulls is given in Table 1.3. For a typical PWR fuel, the mass of Zircaloy hulls is $254 \mathrm{~kg} / \mathrm{tU}$ and SS hardware is $46.9 \mathrm{~kg} / \mathrm{tU}$. The UDS contains fine cladding particles (metal and oxide), metallic fission products, undissolved fuel impurities, and precipitates formed in the dissolver solution. The composition and amount of UDS is therefore dependent on the initial fuel characteristics and the dissolution process, including the potential application of TPT. The assumptions used for this evaluation are summarized in Table 1.4. However, a relatively broad range of split factors could be applied to component partitioning as described in Section 3.5.1.

Table 1.3. Estimated Composition of Washed LWR Hulls for Waste Management

\begin{tabular}{|l|c|l|c|}
\hline Element & $\mathbf{g} / \mathbf{t U}$ & Element & $\mathbf{g} / \mathbf{t U}$ \\
\hline $\mathbf{A c}$ & $1.92 \times 10^{-11}$ & $\mathrm{Pm}$ & 0.0813 \\
\hline $\mathbf{A g}$ & 0.230 & $\mathrm{Pr}$ & 3.38 \\
\hline $\mathbf{A m}$ & 0.193 & $\mathrm{Pu}$ & 5.86 \\
\hline $\mathbf{B a}$ & 5.14 & $\mathrm{Ra}$ & $4.48 \times 10^{-10}$ \\
\hline $\mathbf{C d}$ & 0.396 & $\mathrm{Rb}$ & 1.036 \\
\hline $\mathbf{C e}$ & 7.22 & $\mathrm{Rh}$ & 1.22 \\
\hline $\mathbf{C m}$ & 0.0231 & $\mathrm{Ru}$ & 6.94 \\
\hline $\mathbf{C s}$ & 7.82 & $\mathrm{Sb}$ & 0.0659 \\
\hline $\mathbf{E u}$ & 0.505 & $\mathrm{Se}$ & 0.169 \\
\hline $\mathbf{F e}$ & 0 & $\mathrm{Sm}$ & 2.50 \\
\hline $\mathbf{G d}$ & 0.421 & $\mathrm{Sn}$ & 0.280 \\
\hline${ }^{3} \mathbf{H}$ & 0.0160 & $\mathrm{Sr}$ & 2.42 \\
\hline $\mathbf{L a}$ & 3.70 & $\mathrm{Te}$ & 1.49 \\
\hline $\mathbf{M o}$ & 10.1 & $\mathrm{Tc}$ & 2.27 \\
\hline $\mathbf{N b}$ & $9.40 \times 10^{-6}$ & $\mathrm{Th}$ & $1.62 \times 10^{-6}$ \\
\hline $\mathbf{N d}$ & 12.3 & $\mathrm{U}$ & 467 \\
\hline $\mathbf{N p}$ & 0.195 & $\mathrm{Xe}$ & 0 \\
\hline $\mathbf{O}$ & 67.4 & $\mathrm{Y}$ & 1.35 \\
\hline Pa & $1.76 \times 10^{-7}$ & $\mathrm{Zr}(\mathrm{FP})$ & 10.7 \\
\hline Pb & $2.90 \times 10^{-8}$ & $\mathrm{Zircaloy}-4$ & 253000 \\
\hline Pd & 4.70 & $\mathrm{Total}$ & 254000 \\
\hline
\end{tabular}


Table 1.4. Summary of the Assumed UDS Split from the Dissolver Solution and the Resulting UDS Composition

\begin{tabular}{|l|c|c|c|}
\hline Element & Dissolver, g/tU & Split, $\%$ & UDS, g/tU \\
\hline Ag & 115 & 1 & 1.15 \\
\hline I & 21.4 & 17 & 3.64 \\
\hline Mo & 5050 & 50 & 2520 \\
\hline Nb & 0.00469 & 99 & 0.00464 \\
\hline $\mathbf{O}$ & 135000 & & 270 \\
\hline Pd & 2350 & 99 & 2320 \\
\hline Pu & 11700 & 0.2 & 23.4 \\
\hline Rh & 608 & 99 & 602 \\
\hline Ru & 3460 & 50 & 1730 \\
\hline Sn & 140 & 1 & 1.40 \\
\hline Tc & 1130 & 50 & 566 \\
\hline Te & 744 & 50 & 372 \\
\hline $\mathbf{U}$ & 934000 & 0.055 & 514 \\
\hline $\mathbf{Z r}$ & 5360 & 5 & 268 \\
\hline Zy4 & 254 & 100 & 254 \\
\hline Total & 1099000 & & 9446 \\
\hline
\end{tabular}

\subsubsection{Co-decontamination}

In the co-decontamination process $\mathrm{U}, \mathrm{Pu}, \mathrm{Np}$, and Tc are extracted from the $\mathrm{HNO}_{3}$ solution into kerosene (or other organic diluent) and tributyl phosphate (TBP). A Pu+Np+U and U+Tc stream are selectively stripped from the TBP. The U+Tc stream is then further separated by reextraction and selective stripping. The co-decontamination process can be performed in pulsed columns, mixer settler tanks, or centrifugal contactors depending on the required residence time. The co-decontamination raffinate is further processed for MA separations in the ALS process, the $\mathrm{Pu}+\mathrm{Np}+\mathrm{U}$ and $\mathrm{U}$ product streams are solidified with modified direct denitration (MDD), the Tc product is managed as a waste, and off-gases are managed as part of the combined vessel ventilation off-gas (VOG) treatment process.

The co-decontamination process does not directly produce waste for management. The raffinate is further treated in the ALS process and the off-gases are treated in the VOG process.

\subsubsection{Actinide-Lanthanide Separation}

Trivalent actinides (i.e., Am and $\mathrm{Cm}$ ) are separated from the fission product lanthanides and the other fission products in the co-decontamination raffinate with two solvent extraction processes -- TRUEX and TALSPEAK. First, the trivalent actinides and lanthanides are extracted into octyl(phenyl)-N,Ndiisobutylcarbamoylmethylphosphine oxide (CMPO) and TBP in $n$-dodecane. The lanthanides and actinides are stripped with diethylenetriaminepentaacetic acid (DTPA) in lactate solution (for the nominal flowsheet) or N-(2-hydroxyethyl)ethylenediamine-N,N',N'-triacetic acid (HEDTA) in citrate (for the advanced target flowsheet). The TRUEX raffinate is managed as HLW. The lanthanides are extracted from the TRUEX product into $n$-dodecane with bis-(2-ethylhexyl)phosphoric acid (HDEHP) (in the nominal flowsheet) or 2-ethylhexylphosphonic acid mono-2-ethylhexyl ester (HEH[EHP]) (in the advanced target flowsheet). The TALSPEAK raffinate is solidified for use in FR fuel fabrication while the lanthanides are stripped into $6 \underline{\mathrm{M} \mathrm{HNO}} \mathrm{HN}_{3}$ and combined with the rest of the HLW. Off-gases are managed in the VOG process. 
The UDS slurry, Tc solution, TRUEX raffinate, and TALSPEAK products, combined, make up the aqueous reprocessing HLW. The compositions and masses of these wastes are given in Table 1.4. These streams are combined in two groups - the TRUEX raffinate and TALSPEAK products alone and the combination of all four streams. Solvents used in the co-decontamination and ALS processes are scrubbed in sodium-containing solutions and recycled. The scrub solutions, containing sodium and organic degradation products, are managed as wastes.

Table 1.5. Nominal HLW Stream Compositions, $\mathrm{kg} / \mathrm{tU}$

\begin{tabular}{|c|c|c|c|c|c|c|}
\hline $\mathrm{kg} / \mathrm{tU}$ & $\begin{array}{l}\text { UDS } \\
\text { Slurry } \\
\end{array}$ & $\begin{array}{l}\text { Tc } \\
\text { Solution } \\
\end{array}$ & $\begin{array}{l}\text { TRUEX } \\
\text { Raffinate } \\
\end{array}$ & $\begin{array}{l}\text { TALSPEAK } \\
\text { Product }\end{array}$ & $\begin{array}{l}\text { Mixed feed } \\
\text { w/UDS/Tc }\end{array}$ & $\begin{array}{l}\text { Mixed feed } \\
\text { w/o UDS/Tc }\end{array}$ \\
\hline $\mathbf{A c}$ & $0.00 \mathrm{E}+00$ & $1.69 \mathrm{E}-22$ & $6.41 \mathrm{E}-11$ & $6.41 \mathrm{E}-16$ & $6.41 \mathrm{E}-11$ & $6.41 \mathrm{E}-11$ \\
\hline Ag & $1.15 \mathrm{E}-03$ & $1.37 \mathrm{E}-18$ & $1.14 \mathrm{E}-01$ & $1.14 \mathrm{E}-06$ & $1.15 \mathrm{E}-01$ & $1.14 \mathrm{E}-01$ \\
\hline Am & $0.00 \mathrm{E}+00$ & $1.48 \mathrm{E}-10$ & $6.41 \mathrm{E}-06$ & $6.41 \mathrm{E}-06$ & $1.28 \mathrm{E}-05$ & $1.28 \mathrm{E}-05$ \\
\hline Ba & $0.00 \mathrm{E}+00$ & $0.00 \mathrm{E}+00$ & $0.00 \mathrm{E}+00$ & $0.00 \mathrm{E}+00$ & $0.00 \mathrm{E}+00$ & $0.00 \mathrm{E}+00$ \\
\hline Ba & $0.00 \mathrm{E}+00$ & $5.28 \mathrm{E}-15$ & $2.57 \mathrm{E}+00$ & $2.57 \mathrm{E}-05$ & $2.57 \mathrm{E}+00$ & $2.57 \mathrm{E}+00$ \\
\hline $\mathrm{Ca}$ & $0.00 \mathrm{E}+00$ & $0.00 \mathrm{E}+00$ & $0.00 \mathrm{E}+00$ & $0.00 \mathrm{E}+00$ & $0.00 \mathrm{E}+00$ & $0.00 \mathrm{E}+00$ \\
\hline Cd & $0.00 \mathrm{E}+00$ & $2.37 \mathrm{E}-18$ & $1.97 \mathrm{E}-01$ & $1.97 \mathrm{E}-06$ & $1.97 \mathrm{E}-01$ & $1.97 \mathrm{E}-01$ \\
\hline $\mathrm{Ce}$ & $0.00 \mathrm{E}+00$ & $4.90 \mathrm{E}-13$ & $3.60 \mathrm{E}-05$ & $3.60 \mathrm{E}+00$ & $3.60 \mathrm{E}+00$ & $3.60 \mathrm{E}+00$ \\
\hline $\mathrm{Cm}$ & $0.00 \mathrm{E}+00$ & $1.78 \mathrm{E}-11$ & $7.69 \mathrm{E}-07$ & $7.69 \mathrm{E}-07$ & $1.54 \mathrm{E}-06$ & $1.54 \mathrm{E}-06$ \\
\hline $\mathrm{Cr}$ & $0.00 \mathrm{E}+00$ & $0.00 \mathrm{E}+00$ & $0.00 \mathrm{E}+00$ & $0.00 \mathrm{E}+00$ & $0.00 \mathrm{E}+00$ & $0.00 \mathrm{E}+00$ \\
\hline Cs & $0.00 \mathrm{E}+00$ & $3.55 \mathrm{E}-15$ & $3.90 \mathrm{E}+00$ & $3.90 \mathrm{E}-05$ & $3.90 \mathrm{E}+00$ & $3.90 \mathrm{E}+00$ \\
\hline Eu & $0.00 \mathrm{E}+00$ & $3.43 \mathrm{E}-14$ & $2.52 \mathrm{E}-06$ & $2.52 \mathrm{E}-01$ & $2.52 \mathrm{E}-01$ & $2.52 \mathrm{E}-01$ \\
\hline $\mathbf{F e}$ & $0.00 \mathrm{E}+00$ & $0.00 \mathrm{E}+00$ & $0.00 \mathrm{E}+00$ & $0.00 \mathrm{E}+00$ & $0.00 \mathrm{E}+00$ & $0.00 \mathrm{E}+00$ \\
\hline Gd & $0.00 \mathrm{E}+00$ & $4.20 \mathrm{E}-18$ & $2.10 \mathrm{E}-06$ & $2.10 \mathrm{E}-01$ & $2.10 \mathrm{E}-01$ & $2.10 \mathrm{E}-01$ \\
\hline I & $3.54 \mathrm{E}-03$ & $0.00 \mathrm{E}+00$ & $8.65 \mathrm{E}-03$ & $8.65 \mathrm{E}-08$ & $1.22 \mathrm{E}-02$ & $8.66 \mathrm{E}-03$ \\
\hline La & $0.00 \mathrm{E}+00$ & $2.51 \mathrm{E}-13$ & $1.84 \mathrm{E}-05$ & $1.84 \mathrm{E}+00$ & $1.84 \mathrm{E}+00$ & $1.84 \mathrm{E}+00$ \\
\hline Mo & $2.52 \mathrm{E}+00$ & $3.03 \mathrm{E}-17$ & $2.52 \mathrm{E}+00$ & $2.52 \mathrm{E}-05$ & $5.04 \mathrm{E}+00$ & $2.52 \mathrm{E}+00$ \\
\hline $\mathrm{Na}$ & $0.00 \mathrm{E}+00$ & $0.00 \mathrm{E}+00$ & $0.00 \mathrm{E}+00$ & $0.00 \mathrm{E}+00$ & $0.00 \mathrm{E}+00$ & $0.00 \mathrm{E}+00$ \\
\hline Nb & 4.64E-06 & $5.63 \mathrm{E}-25$ & $4.69 \mathrm{E}-08$ & $4.69 \mathrm{E}-13$ & $4.69 \mathrm{E}-06$ & $4.69 \mathrm{E}-08$ \\
\hline Nd & $0.00 \mathrm{E}+00$ & $6.58 \mathrm{E}-15$ & $6.12 \mathrm{E}-05$ & $6.12 \mathrm{E}+00$ & $6.12 \mathrm{E}+00$ & $6.12 \mathrm{E}+00$ \\
\hline $\mathbf{N i}$ & $0.00 \mathrm{E}+00$ & $0.00 \mathrm{E}+00$ & $0.00 \mathrm{E}+00$ & $0.00 \mathrm{E}+00$ & $0.00 \mathrm{E}+00$ & $0.00 \mathrm{E}+00$ \\
\hline Np & $0.00 \mathrm{E}+00$ & $1.95 \mathrm{E}-10$ & $6.49 \mathrm{E}-04$ & $0.00 \mathrm{E}+00$ & $6.49 \mathrm{E}-04$ & $6.49 \mathrm{E}-04$ \\
\hline $\mathrm{Pa}$ & $0.00 \mathrm{E}+00$ & $7.03 \mathrm{E}-24$ & $5.85 \mathrm{E}-12$ & $5.85 \mathrm{E}-07$ & $5.85 \mathrm{E}-07$ & $5.85 \mathrm{E}-07$ \\
\hline $\mathbf{P b}$ & $0.00 \mathrm{E}+00$ & $1.74 \mathrm{E}-25$ & $1.45 \mathrm{E}-08$ & $1.45 \mathrm{E}-13$ & $1.45 \mathrm{E}-08$ & $1.45 \mathrm{E}-08$ \\
\hline Pd & $2.32 \mathrm{E}+00$ & $2.82 \mathrm{E}-19$ & $2.35 \mathrm{E}-02$ & $2.35 \mathrm{E}-07$ & $2.34 \mathrm{E}+00$ & $2.35 \mathrm{E}-02$ \\
\hline Pm & $0.00 \mathrm{E}+00$ & $2.84 \mathrm{E}-13$ & $4.05 \mathrm{E}-07$ & $4.05 \mathrm{E}-02$ & $4.05 \mathrm{E}-02$ & $4.05 \mathrm{E}-02$ \\
\hline Pr & $0.00 \mathrm{E}+00$ & $8.43 \mathrm{E}-15$ & $1.69 \mathrm{E}-05$ & $1.69 \mathrm{E}+00$ & $1.69 \mathrm{E}+00$ & $1.69 \mathrm{E}+00$ \\
\hline $\mathbf{P u}$ & $2.34 \mathrm{E}-02$ & $3.51 \mathrm{E}-09$ & $1.17 \mathrm{E}-09$ & $1.17 \mathrm{E}-09$ & $2.34 \mathrm{E}-02$ & $2.34 \mathrm{E}-09$ \\
\hline Ra & $0.00 \mathrm{E}+00$ & $2.68 \mathrm{E}-27$ & $2.23 \mathrm{E}-10$ & $2.23 \mathrm{E}-15$ & $2.23 \mathrm{E}-10$ & $2.23 \mathrm{E}-10$ \\
\hline $\mathbf{R b}$ & $0.00 \mathrm{E}+00$ & $6.20 \mathrm{E}-18$ & $5.17 \mathrm{E}-01$ & $5.17 \mathrm{E}-06$ & $5.17 \mathrm{E}-01$ & $5.17 \mathrm{E}-01$ \\
\hline Rh & $6.02 \mathrm{E}-01$ & $7.30 \mathrm{E}-20$ & $6.08 \mathrm{E}-03$ & $6.08 \mathrm{E}-08$ & $6.08 \mathrm{E}-01$ & $6.08 \mathrm{E}-03$ \\
\hline Ru & $1.73 \mathrm{E}+00$ & $5.26 \mathrm{E}-07$ & $1.71 \mathrm{E}+00$ & $1.71 \mathrm{E}-05$ & $3.44 \mathrm{E}+00$ & $1.71 \mathrm{E}+00$ \\
\hline Sb & $0.00 \mathrm{E}+00$ & $3.94 \mathrm{E}-19$ & $3.29 \mathrm{E}-02$ & $3.29 \mathrm{E}-07$ & $3.29 \mathrm{E}-02$ & $3.29 \mathrm{E}-02$ \\
\hline $\mathrm{Se}$ & $0.00 \mathrm{E}+00$ & $1.01 \mathrm{E}-18$ & $8.45 \mathrm{E}-02$ & $8.45 \mathrm{E}-07$ & $8.45 \mathrm{E}-02$ & $8.45 \mathrm{E}-02$ \\
\hline Sm & $0.00 \mathrm{E}+00$ & $2.51 \mathrm{E}-12$ & $1.25 \mathrm{E}-05$ & $1.25 \mathrm{E}+00$ & $1.25 \mathrm{E}+00$ & $1.25 \mathrm{E}+00$ \\
\hline Sn & $1.40 \mathrm{E}-03$ & $1.66 \mathrm{E}-18$ & $1.38 \mathrm{E}-01$ & $1.38 \mathrm{E}-06$ & $1.39 \mathrm{E}-01$ & $1.38 \mathrm{E}-01$ \\
\hline $\mathrm{Sr}$ & $0.00 \mathrm{E}+00$ & $2.48 \mathrm{E}-15$ & $1.21 \mathrm{E}+00$ & $1.21 \mathrm{E}-05$ & $1.21 \mathrm{E}+00$ & $1.21 \mathrm{E}+00$ \\
\hline $\mathrm{Te}$ & $3.72 \mathrm{E}-01$ & $4.46 \mathrm{E}-18$ & $3.72 \mathrm{E}-01$ & $3.72 \mathrm{E}-06$ & $7.44 \mathrm{E}-01$ & $3.72 \mathrm{E}-01$ \\
\hline Tc & $5.66 \mathrm{E}-01$ & $5.38 \mathrm{E}-01$ & $5.66 \mathrm{E}-03$ & $5.66 \mathrm{E}-08$ & $1.11 \mathrm{E}+00$ & $5.66 \mathrm{E}-03$ \\
\hline Th & $0.00 \mathrm{E}+00$ & $1.43 \mathrm{E}-17$ & $5.41 \mathrm{E}-11$ & $5.41 \mathrm{E}-11$ & $1.08 \mathrm{E}-10$ & $1.08 \mathrm{E}-10$ \\
\hline $\mathbf{U}$ & $5.14 \mathrm{E}-01$ & $9.34 \mathrm{E}-04$ & $0.00 \mathrm{E}+00$ & $2.80 \mathrm{E}-07$ & $5.15 \mathrm{E}-01$ & $2.80 \mathrm{E}-07$ \\
\hline $\mathbf{Y}$ & $0.00 \mathrm{E}+00$ & $9.18 \mathrm{E}-14$ & $2.02 \mathrm{E}-02$ & $6.54 \mathrm{E}-01$ & $6.74 \mathrm{E}-01$ & $6.74 \mathrm{E}-01$ \\
\hline $\mathbf{Z r}$ & $5.22 \mathrm{E}-01$ & $6.84 \mathrm{E}-09$ & $5.09 \mathrm{E}+00$ & $5.09 \mathrm{E}-05$ & $5.61 \mathrm{E}+00$ & $5.09 \mathrm{E}+00$ \\
\hline Total & $9.18 \mathrm{E}+00$ & $5.39 \mathrm{E}-01$ & $1.85 \mathrm{E}+01$ & $1.57 \mathrm{E}+01$ & $4.39 \mathrm{E}+01$ & $3.42 \mathrm{E}+01$ \\
\hline
\end{tabular}




\subsubsection{Off-Gas Treatment}

Off-gas treatment systems are required to reduce the emissions from an aqueous reprocessing plant to safe and regulatory compliant levels. Four primary off-gas treatment systems are considered: 1) dissolver offgas (DOG) for the nominal flowsheet or 2) combined head-end off-gas (HOG) for the advanced flowsheet in which the dissolver and TPT off-gas (TOG) are managed; plus 3) vessel ventilation system off-gas (VOG) and 4) HLW melter off-gas (MOG). Cell off-gas (COG) is assumed to be treated only by filtration and isn't specifically addressed in this section.

Off-gas decontamination factor (DF) requirements for an aqueous reprocessing facility are determined by federal regulations 40 CFR 61 (EPA 2010a), 40 CFR 190 (EPA 2010b), and 10 CFR 20 (NRC 2012).

These regulations apply to the release of specific radionuclides and establish dose limits for the maximum exposed individual (MEI) in the public, both in terms of whole body dose and dose to specific organs, e.g., the thyroid (Soelberg et al. 2013). Jubin et al. (2012a) describe the application of these regulations to a UNF reprocessing facility and derive a set of DF requirements summarized in Table 1.6 for four volatile, radioactive off-gas components. Relatively high DFs are also required for aerosol and particulate matter that require specific knowledge of radionuclide content to accurately determine a DF requirement - a DF requirement of 1000 is assumed.

Table 1.6. Estimated DFs for 5- and 50-y Cooled PWR UOX Fuel Reprocessed in a 1000 tU/y Plant

\begin{tabular}{|r|c|c|c|c|}
\hline Isotope & \multicolumn{2}{|c|}{ HOG/DOG DFs } & \multicolumn{2}{c|}{ VOG and MOG DFs } \\
\hline Cooling & $\mathbf{5} \mathbf{y}$ & $\mathbf{5 0} \mathbf{y}$ & $\mathbf{5} \mathbf{y}$ & $\mathbf{5 0} \mathbf{y}$ \\
\hline${ }^{3} \mathbf{H}$ & 100 or 1 & 7 or 1 & 1 & 1 \\
\hline${ }^{14} \mathbf{C}$ & 10 & 10 & 1 & 1 \\
\hline${ }^{85} \mathbf{K r}$ & 100 & 1 & 1 & 1 \\
\hline${ }^{129} \mathbf{I}$ & 3000 & 3000 & 1000 & 1000 \\
\hline
\end{tabular}

\subsubsection{Dissolver Off-Gas}

The highest fractions of fission gases ${ }^{14} \mathrm{C},{ }^{129} \mathrm{I}$, and ${ }^{85} \mathrm{Kr}$ are released in the head-end process. The proposed nominal flowsheet for capturing these gases is shown in Figure 1.3. For some of the unit operations there is sufficient basis to select a preferred option, while for others multiple options are recommended. Gases from the shearing cell flow through the dissolver. The segmented fuel is dissolved in roughly $7 \underline{\mathrm{M}} \mathrm{HNO}_{3}$ from which roughly $94 \%$ of the I inventory is released as a combination of $\mathrm{I}_{2}$ and inorganic and organic iodides; between 50 and $100 \%$ of the ${ }^{14} \mathrm{C}$ inventory is released as $\mathrm{CO}_{2}$; and roughly $100 \%$ of the ${ }^{85} \mathrm{Kr}$ inventory is released as $\mathrm{Kr}$ in the nominal case (or 50\% released in both the TOG and the DOG in the advanced case); all in a water-saturated, high nitrogen oxides $\left(\mathrm{NO}_{\mathrm{x}}\right)$, air stream. A two stage condenser is used to recycle water and $\mathrm{HNO}_{3}$ to the dissolver. The off-gas from the shearing and dissolver cells are combined and passed through an iodine filter. The composition and mass of the combined gas stream is given in Table 1.7. The gas is heated to $\sim 150{ }^{\circ} \mathrm{C}$ and passed through an iodine filter. The two filter media currently under development for this application are the silver mordenite (ideally $\left[\mathrm{Ca}, \mathrm{Na}_{2}, \mathrm{~K}_{2}\right] \mathrm{Al}_{2} \mathrm{Si}_{10} \mathrm{O}_{24} \cdot 7 \mathrm{H}_{2} \mathrm{O}$ ), in which the $\mathrm{Ca}$, $\mathrm{Na}$ or $\mathrm{K}$ in the base zeolite is exchanged with $\mathrm{Ag}^{+}$ ( $\mathrm{AgZ}$ ), which is subsequently reduced to $\mathrm{Ag}^{0}$ with $\mathrm{H}^{2}$ ) and silver-functionalized silica aerogel (AgAero). Other media and methods for capture of radioiodine have been reviewed separately (Brown et al. 1983; Burger and Scheele 1983; Gombert et al. 2007; Holladay 1979; Jubin 1979; IAEA 1987; Soelberg et al. 2013). Both the AgZ and AgAero are expected to achieve DFs between 1000 and 10000 for $I_{2}$ (Soelberg and Watson 2012) and roughly 1000 for organic iodides for AgZ (Jubin 1983; Scheele et al. 1983). Other halogens found in the off-gas stream are also captured on the media. Two primary sources of additional halogen are fission products ( $\mathrm{F}$ and $\mathrm{Br}$ ) and impurities from $\mathrm{HNO}_{3}$ used in the process $(\mathrm{Cl}$ and potentially 
F). Assuming $1556 \mathrm{~kg}$ of $\mathrm{HNO}_{3}$ are consumed per $\mathrm{tU}$ processed and the $\mathrm{HNO}_{3}$ contains $100 \mathrm{ppm} \mathrm{Cl}$, the gas contains $\sim 160 \mathrm{~g} \mathrm{Cl} / \mathrm{tU}$.

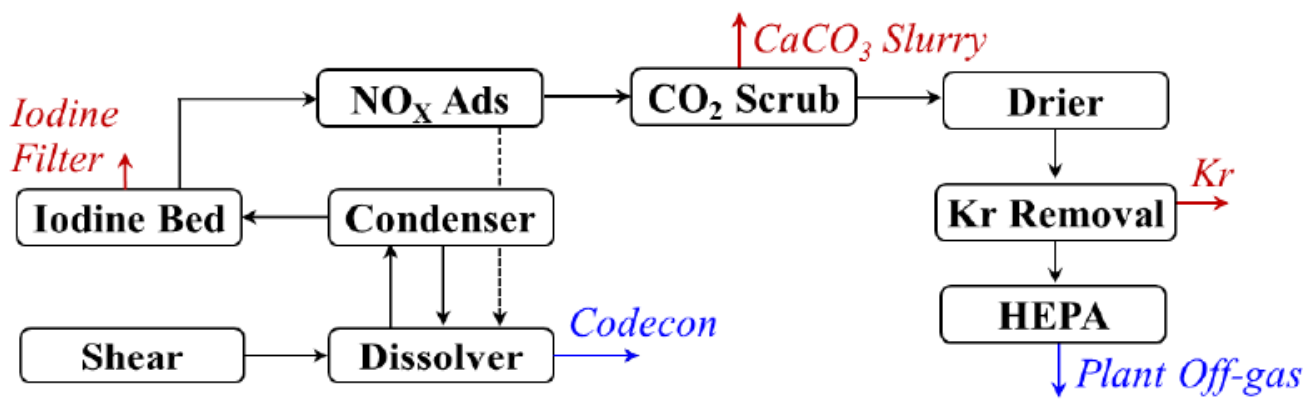

Figure 1.3. Nominal DOG Flowsheet Schematic

Table 1.7. Nominal Combined Gas Composition Entering the Iodine Bed

\begin{tabular}{|l|c|c|c|}
\hline Component & g/tU & Component & $\mathbf{~ k g / t U}$ \\
\hline${ }^{14} \mathbf{C}$ & 0.3000 & Air & 14983 \\
\hline${ }^{3} \mathbf{H}$ & $6.46 \times 10^{-4}$ & $\mathrm{~N}_{2}$ & 11314 \\
\hline I-total & 336.0 & $\mathrm{O}_{2}$ & 3467 \\
\hline Kr-total & 539.7 & $\mathrm{Ar}$ & 193.0 \\
\hline $\mathbf{X e - t o t a l}$ & 7992 & $\mathrm{CO}_{2}$ & 9.04 \\
\hline $\mathbf{N O}$ & 24490 & & \\
\hline $\mathbf{N O}$ & 89232 & & \\
\hline $\mathbf{H}_{2} \mathbf{O}$ & 183705 & & \\
\hline $\mathbf{C l}$ & 160 & & \\
\hline $\mathbf{B r}$ & 36 & & \\
\hline $\mathbf{F}$ & $2.2 \times 10^{-6}$ & & \\
\hline
\end{tabular}

Basis: DOG rate $4050 \mathrm{~L} / \mathrm{min}$ and shear air flow of $4610 \mathrm{~L} / \mathrm{min}$ for $1000 \mathrm{tU} / \mathrm{y}$ facility; Air cell at $7{ }^{\circ} \mathrm{C}$ dew point ( $1 \mathrm{vol} \% \mathrm{H}_{2} \mathrm{O}$ ); DOG cooled to $25^{\circ} \mathrm{C}$ leaving dissolver; $\mathrm{No}_{\mathrm{CO}_{2}}$ removal for DOG sparge air

After iodine adsorption, $\mathrm{NO}_{\mathrm{x}}$ is removed with wet scrubbing in the presence of air (although oxygen sparging may ultimately be needed). The resulting $\mathrm{HNO}_{3}$ solution is returned to the dissolver. Carbon-14 is scrubbed from the resulting gas stream in a $1.6 \underline{\mathrm{M} \mathrm{NaOH}}$ solution (Goossens et al. 1991). It should be noted that the air inlet to both the shearing cell and air sparging of the dissolver contains non-radioactive $\mathrm{CO}_{2}$ that overwhelms the mass of ${ }^{14} \mathrm{CO}_{2}$ from the fuel at an estimated ratio of roughly 1300:1. This mass can be significantly reduced by removing $\mathrm{CO}_{2}$ from the air prior to sparging the dissolver and sweeping the shearing cell with it (as discussed in Section 2.4). Captured $\mathrm{CO}_{2}$ is precipitated as calcium carbonate that is approximately $800 \mathrm{~g} / \mathrm{L} \mathrm{CaCO}_{3}$ in $1.6 \underline{\mathrm{M} \mathrm{NaOH}}$.

Two methods are postulated to remove $\mathrm{Kr}$ from the resulting gas stream, if necessary (although processing UNF older than roughly 34 years would not require $\mathrm{Kr}$ capture under current regulations) - 1) cryogenic distillation and 2) adsorption. The most proven technology is cryogenic distillation, which requires removal of any components that will condense at liquid $\mathrm{N}_{2}$ temperatures, including $\mathrm{O}_{2} ; \mathrm{H}_{2} \mathrm{O}$; $\mathrm{CO}_{2}$; and $\mathrm{NO}_{\mathrm{x}}$. Oxygen is catalytically reduced with $\mathrm{H}_{2}$, trace $\mathrm{NO}_{\mathrm{x}}$ is removed with ammonia selective catalytic reduction (SCR), and the gas stream is dried to a dew point of $-90^{\circ} \mathrm{C}$ with a condenser followed by molecular sieve. The resulting gas stream is cryogenically distilled to separate $\mathrm{Kr}$ from $\mathrm{N}_{2}$ and $\mathrm{Xe}$. 
The $\mathrm{Kr}$ gas stream contains $99.9 \%$ of the $\mathrm{Kr}$ from the fuel in a mixture of $80 \mathrm{vol} \% \mathrm{Kr}, 10 \mathrm{vol} \% \mathrm{Xe}$, and $10 \mathrm{vol} \% \mathrm{H}_{2}$ (from $\mathrm{O}_{2}$ removal).

In the adsorption process, $\mathrm{Xe}$ is first removed with a bed of $\mathrm{AgZ}$ or a metal organic framework (MOF). The $\mathrm{Kr}$ is then captured with either a hydrogen mordenite (HZ) bed operated at $-80^{\circ} \mathrm{C}$ to $-150{ }^{\circ} \mathrm{C}$ (Gombert et al. 2007) or on a MOF at $0{ }^{\circ} \mathrm{C}$ to $-40{ }^{\circ} \mathrm{C}$ (Thallapally et al. 2013; Thallapally and Strachan 2012). The lower temperature method still requires drying, but neither approach requires $\mathrm{CO}_{2}, \mathrm{NO}_{\mathrm{x}}$, or $\mathrm{O}_{2}$ removal. Generally, lower temperatures achieve higher loading and smaller beds. It is assumed that $95 \%$ of the $\mathrm{Xe}$ is removed in the first bed and $5 \%$ of the $\mathrm{Xe}$ and $99.9 \%$ of the $\mathrm{Kr}$ is removed in the second bed.

The resulting gas is released to the plant off-gas management system where it is combined with other process gases, filtered, and released through the facility exhaust stack.

\subsubsection{Head-End Off-Gas}

The HOG is the combined off-gas from the shear, TPT, and dissolver in the advanced flowsheet. The primary difference between this and the DOG is the evolution of ${ }^{3} \mathrm{H}$ early in the process where it is captured in the off-gas treatment system. The proposed flowsheet for capturing ${ }^{3} \mathrm{H},{ }^{14} \mathrm{C},{ }^{129} \mathrm{I}$, and ${ }^{85} \mathrm{Kr}$ from the head-end processes is shown in Figure 1.4.

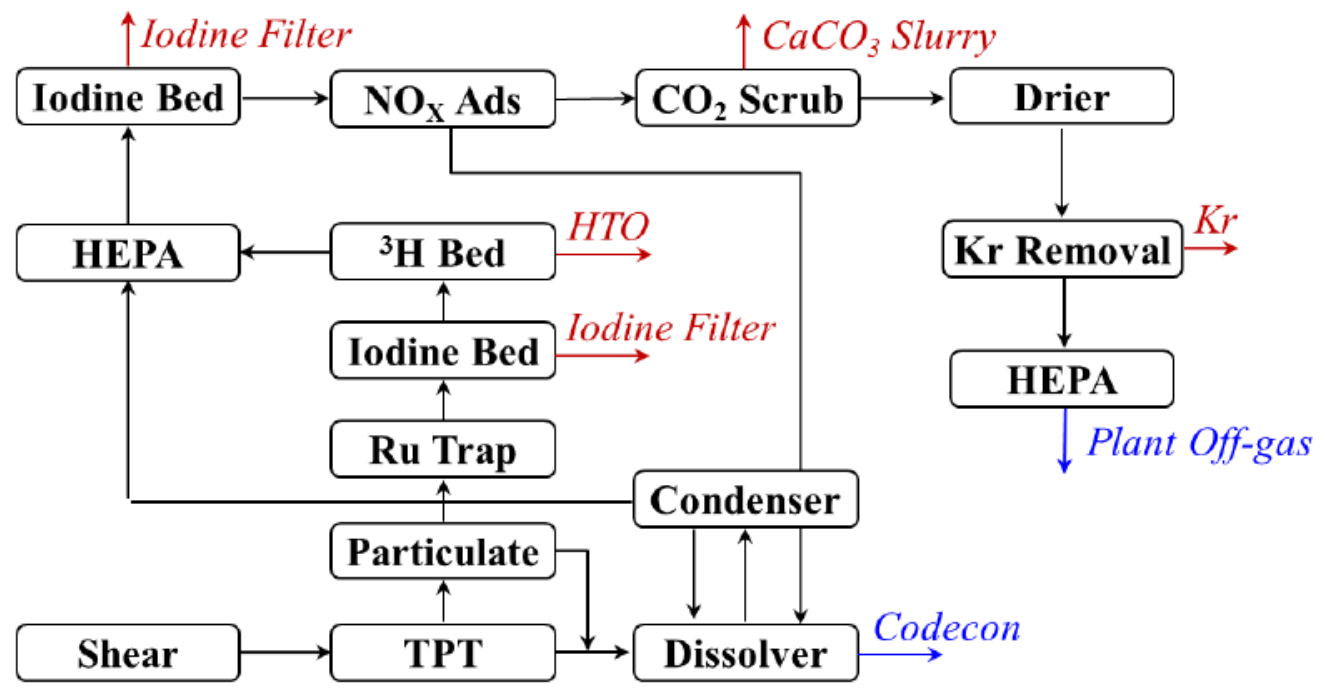

Figure 1.4. Advanced HOG Flowsheet Schematic

The chopped fuel is transferred to a calciner where it is oxidized in dry air at roughly $500{ }^{\circ} \mathrm{C}$ (Jubin et al. 2009). The gases from the oxidizer are filtered through a sintered metal filter that is back pulsed to return most of the particulate to the dissolver. The gases are then contacted by a silica gel ruthenium trap (Goossens et al. 1991), heated, and passed through an iodine column containing either AgZ or AgAero operating at $150{ }^{\circ} \mathrm{C}$. The iodine free gas is treated with a Linde molecular sieve 3A (MS3A) to remove water vapor containing HTO. The MS3A bed is heated to remove water and regenerate the media. Between 4 and 7 times greater water volume than the water equivalent of the ${ }^{3} \mathrm{H}$ inventory in the fuel is captured because of the water in the TPT air (dew point of $-60^{\circ} \mathrm{C}$ ). Dried gases are combined with the shear cell sweep gas and the DOG and are passed through a HEPA filter. The HOG compositions are listed in Table 1.8. 
Table 1.8. Composition of HOG Components at Various Stages, $\mathrm{kg} / \mathrm{tU}$ reprocessed

\begin{tabular}{|c|c|c|c|}
\hline Stream & $\begin{array}{l}\text { TPT (Ru trap } \\
\text { outlet) gas }\end{array}$ & $\begin{array}{l}\text { Dissolver } \\
\text { (condenser } \\
\text { outlet) gas } \\
\end{array}$ & $\begin{array}{l}\text { Combined HOG } \\
\text { gas (entering } \\
\text { second iodine bed) }\end{array}$ \\
\hline${ }^{14} \mathrm{C}$ & $1.48 \times 10^{-4}$ & $1.48 \times 10^{-4}$ & $2.98 \times 10^{-4}$ \\
\hline${ }^{3} \mathbf{H}$ & $4.79 \times 10^{-5}$ & 0 & $1.12 \times 10^{-6}$ \\
\hline $\mathbf{I}_{2}$ & $3.56 \times 10^{-3}$ & 0.338 & 0.339 \\
\hline $\mathbf{K r}$ & 0.262 & 0.262 & 0.540 \\
\hline $\mathbf{X e}$ & 3.88 & 3.88 & 7.99 \\
\hline Air & 0 & 7980 & 15000 \\
\hline $\begin{array}{r}\text { Tramp } \mathrm{CO}_{2} \\
\text { in air }\end{array}$ & 0 & 4.88 & 9.16 \\
\hline $\mathbf{N}_{2}$ & 6.89 & & 6.89 \\
\hline $\mathbf{O}_{2}$ & 2.09 & 41.9 & 44.0 \\
\hline NO & 0 & 24.9 & 24.9 \\
\hline $\mathrm{NO}_{2}$ & 0 & 89.2 & 89.2 \\
\hline $\mathrm{HNO}_{3}$ & 0 & 175 & 0 \\
\hline $\mathrm{H}_{2} \mathrm{O}+\mathrm{HTO}$ & $7.19 \times 10^{-4}$ & 20.9 & 64.7 \\
\hline Total mass & 13.1 & 8170 & 15200 \\
\hline
\end{tabular}

\subsubsection{Vessel Vent Off-gas}

The vessel ventilation system off-gases are a high volume stream in which aerosol, particulate and iodine (and potentially $\mathrm{NO}_{\mathrm{x}}$ and organics) must be removed. The proposed nominal flowsheet for capturing these gases is shown in Figure 1.5. Aerosols from each vessel are removed at the source with a mist filter that is periodically back-washed into the same vessel. The vent system flows are combined, heated, and filtered for iodine and particulates as described above. The challenge in filtering this gas stream is the high flow rates with relatively low iodine concentrations. For example, VOG and DOG gas flows are compared in Table 1.9. Generally, the concentrations of iodine are between 100 and 1000 times lower in the VOG than the DOG and the flow rates of the VOG are about 10 times higher.

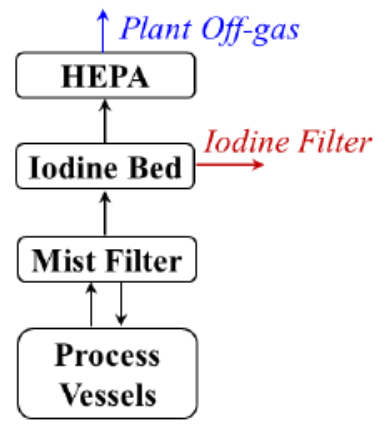

Figure 1.5. Nominal Vessel Ventilation Off-gas Treatment Process Schematic. 
Table 1.9. Comparison of DOG and VOG Flows in $\mathrm{kg} / \mathrm{tU}$ Processed

\begin{tabular}{|l|c|c|c|}
\hline Component & $\begin{array}{r}\text { Dissolver (condenser } \\
\text { outlet) gas }\end{array}$ & $\begin{array}{r}\text { VOG, Post Mist } \\
\text { Filter }\end{array}$ & Denitration VOG \\
\hline${ }^{14} \mathbf{C}$ & $3.0 \times 10^{-4}$ & $3.0 \times 10^{-8}$ & 0 \\
\hline${ }^{3} \mathbf{H}$ & $5.8 \times 10^{-11}$ & $6.5 \times 10^{-9}$ & \\
\hline $\mathbf{I}$ & 0.33 & 0.0089 & 0 \\
\hline $\mathbf{K r}$ & 0.53 & 0 & 0 \\
\hline $\mathbf{X e}$ & 7.8 & 0 & 0 \\
\hline $\mathbf{N O}$ & 24.9 & 25.2 & 0 \\
\hline $\mathbf{N O}_{2}$ & 89.2 & 9.66 & 387 \\
\hline $\mathbf{N}_{2} \mathbf{O}$ & 0 & 0 & 370 \\
\hline $\mathbf{H N O}_{3}$ & 4.29 & 0 & 0 \\
\hline $\mathbf{H}_{2} \mathbf{O}$ & 156 & 2074 & 52.5 \\
\hline Air & $8.0 \times 10^{3}$ & $7.98 \times 10^{4}$ & $2.63 \times 10^{3}$ \\
\hline Total & $8.27 \times 10^{3}$ & $8.19 \times 10^{4}$ & $3.44 \times 10^{3}$ \\
\hline $\begin{array}{l}\text { These values assume a used fuel reprocessing rate of } 1 \mathrm{tU} / \text { day, without TPT. MDD is assumed } \\
\text { as the denitration process. } \mathrm{H}_{2} \mathrm{O} \text { content assumes air is saturated at } 25{ }^{\circ} \mathrm{C} .\end{array}$ \\
\hline
\end{tabular}

\subsubsection{HLW Melter Off-gas}

The HLW immobilization process is assumed to be vitrification, although other options are being considered. Off-gases from vitrification contain 1) particulate carryover (i.e. entrained solids), 2) condensable volatiles (e.g., compounds of $\mathrm{B}, \mathrm{Na}, \mathrm{Cs}, \mathrm{Ru}$, and $\mathrm{Tc}$ ), 3 ) fixed gases (e.g., $\mathrm{I}_{2}, \mathrm{NO}_{\mathrm{x}}, \mathrm{SO}_{2}, \mathrm{CO}$, $\mathrm{CO}_{2}$ ), and 4) superheated steam (Goles 1992, Soelberg 2009, Jubin 2014a). The composition and flow of this off-gas stream (melter off-gas or MOG) depends on the composition of the melter feed and the melting process (Goles 1992, Soelberg 2001). A range of off-gas treatment technologies have been deployed at different HLW vitrification facilities or could be considered in future HLW vitrification facilities (Table 1.10).

The nominal flowsheet proposed for capturing these gases is shown in Figure 1.6. Other processes can and should be considered feasible options. A film cooler (not shown) cools the gases exiting the melter. An ejector venturi scrubber (EVS) further cools the gas and removes the condensable components, large particulates, and soluble components. Water vapor, aerosols, mists, and soluble components are removed in the high efficiency mist eliminator (HEME). Blowdown from the EVS/HEME is evaporated and the evaporator bottoms are recycled into the HLW melter feed. Gases exiting the HEME are heated and passed through an iodine absorber similar to that described in the DOG treatment system (Section 1.1.4.1). Halogen-free gases are reduced with ammonia in a selective catalytic reducer (SCR) and passed through a HEPA filter before exiting the plant through the stack. Example MOG gas flows are shown in Table 1.11 . 
Table 1.10. Examples MOG Treatment Components and Purposes

\begin{tabular}{|l|l|}
\hline \multicolumn{1}{|c|}{ Equipment } & \multicolumn{1}{c|}{ Purpose } \\
\hline Film Cooler & $\begin{array}{l}\text { Gas, precipitate, and condensable cooling to avoid hard } \\
\text { adhering solids in the transfer line }\end{array}$ \\
\hline Submerged Bed Scrubber (SBS) & Gas cooling; condensable and soluble components scrubbing \\
\hline Ejector-Venturi Scrubber (EVS) & $\begin{array}{l}\text { Gas cooling; condensables, large particulates, and soluble } \\
\text { components scrubbing }\end{array}$ \\
\hline Wet Electrostatic Precipitator (WESP) & Sub-micrometer aerosol and particulate scrubbing \\
\hline High Efficiency Mist Eliminator (HEME) & Remove mist after wet scrubbing \\
\hline Sintered Metal Filters (SMF) & Coarse particulate removal \\
\hline High Efficiency Particulate Air (HEPA) filter & Fine particulate filter \\
\hline Plate Scrubber (Dust Scrubber) & $\begin{array}{l}\text { Large particulate, condensables, and soluble component } \\
\text { removal }\end{array}$ \\
\hline Condenser & Remove moisture \\
\hline $\begin{array}{l}\text { Steam Atomized Scrubber (SAS)/ Hydrosonic } \\
\text { Scrubber }\end{array}$ & Particulate, condensables, and soluble component removal \\
\hline Selective Catalytic Reducer (SCR) & NO destruction \\
\hline Selective Catalytic Oxidizer (SCO) & Organics destruction \\
\hline Silver Absorber & Iodine/halogen absorber \\
\hline NOXIDIZER & Organics and NO destruction \\
\hline Thermal Reaction Chamber (TRC) & Organics and/or NO Xestruction \\
\hline Carbon Bed Scrubber & Mercury removal \\
\hline
\end{tabular}

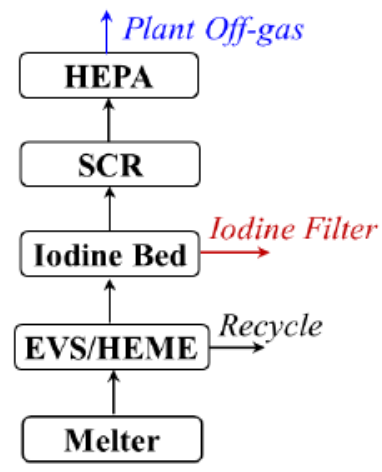

Figure 1.6. Nominal Melter Off-gas Treatment System. 
Table 1.11. Example Vitrification System Off-gas Flows (kg/tU Processed)

\begin{tabular}{|l|r|r|r|}
\hline Component & Melter off-gas & HEME outlet gas & Off-gas to stack \\
\hline Air & 2970 & 2970 & 4300 \\
\hline $\mathbf{H} \mathbf{2}$ & 1040 & 0 & 931 \\
\hline $\mathbf{C s}$ & 0.429 & 0.000433 & $4.33 \mathrm{E}-10$ \\
\hline${ }^{3} \mathbf{H}$ & 0.00391 & $9.78 \mathrm{E}-06$ & $9.78 \mathrm{E}-06$ \\
\hline $\mathbf{I}$ & 0.0116 & 0.00364 & $3.64 \mathrm{E}-05$ \\
\hline Tc & 1.46 & $9.39 \mathrm{E}-05$ & $9.39 \mathrm{E}-11$ \\
\hline $\mathbf{N O}$ & 285 & 269 & 40.4 \\
\hline $\mathbf{N O}_{\mathbf{2}}$ & 285 & 271 & 40.6 \\
\hline $\mathbf{H N O}_{\mathbf{3}}$ & 142 & 0.0283 & 0 \\
\hline $\mathbf{N H}_{\mathbf{3}}$ & 0 & 0 & 7.16 \\
\hline Other & 1.06 & 0.270 & $2.7 \mathrm{E}-07$ \\
\hline Total & 4730 & 3510 & 5320 \\
\hline
\end{tabular}

\subsection{Electrochemical Processing}

The electrochemical (echem) process for the reprocessing of metallic fuel is shown schematically in Figure 1.7. The nominal input FR UNF composition is given in Table 1.12. This fuel is based on a 20 mass \% Pu, $10 \mathrm{Zr}, 0.3 \mathrm{MA}$, and balance depleted U (DU) initial fuel composition irradiated in a SFR to $99.6 \mathrm{GWd} / \mathrm{tHM}$ with a target conversion ratio of 0.75 that has been cooled for $2 \mathrm{y}$. Metallic fuel is first chopped into segments that are loaded into an electrorefiner basket. The electrorefiner contains a molten salt eutectic of $\mathrm{LiCl}$ and $\mathrm{KCl}$ at between 450 and $500{ }^{\circ} \mathrm{C}$. The electrorefiner basket is placed in the molten salt and made the anode of the circuit. Uranium metal is oxidized and transported through the molten salt to the cathode where it is reduced to U metal. Depending on the electrochemical parameters, principally the transuranic-to-uranium ratio in the molten salt, other actinides are transported and reduced as well. The fission products are either left in the anode basket along with the fuel hulls or in the molten salt.

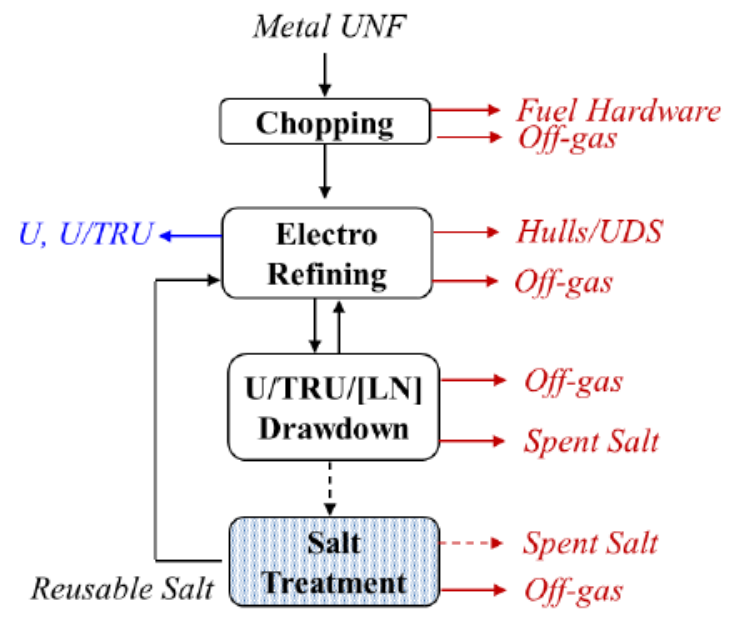

Figure 1.7. General Electrochemical Separations Flowsheet 
Table 1.12. Nominal Composition for Used SFR Metal U/Pu/Zr Fuel, 0.75 Conversion Ratio, $99.6 \mathrm{GWd} / \mathrm{tHM}, 2 \mathrm{y}$ Cooling)

\begin{tabular}{|c|c|}
\hline Elemental & $\mathrm{kg} / \mathrm{tHM}$ \\
\hline Ac & $3.46 \times 10^{-11}$ \\
\hline Ag & 0.645 \\
\hline Am & 9.25 \\
\hline Ba & 4.32 \\
\hline C & 0.175 \\
\hline Cd & 0.432 \\
\hline $\mathrm{Ce}$ & 6.09 \\
\hline $\mathbf{C m}$ & 3.79 \\
\hline Cs & 11.2 \\
\hline Eu & 0.346 \\
\hline Gd & 0.302 \\
\hline${ }^{3} \mathbf{H}$ & $2.28 \times 10^{-4}$ \\
\hline $\mathbf{I}$ & 1.00 \\
\hline $\mathbf{K r}$ & 0.688 \\
\hline La & 3.39 \\
\hline Mo & 9.07 \\
\hline $\mathrm{Na}$ & 24.0 \\
\hline $\mathbf{N b}$ & $5.58 \times 10^{-5}$ \\
\hline Nd & 10.2 \\
\hline Np & 2.06 \\
\hline Pa & $5.50 \times 10^{-7}$ \\
\hline $\mathbf{P b}$ & $5.95 \times 10^{-7}$ \\
\hline Pd & 6.45 \\
\hline Pm & 0.410 \\
\hline Pr & 3.26 \\
\hline $\mathbf{P u}$ & 177 \\
\hline Ra & $3.95 \times 10^{-9}$ \\
\hline $\mathbf{R b}$ & 0.613 \\
\hline $\mathbf{R h}$ & 2.96 \\
\hline $\mathbf{R u}$ & 8.62 \\
\hline Sb & 0.102 \\
\hline Se & 0.0959 \\
\hline Sm & 2.99 \\
\hline Sn & 0.335 \\
\hline $\mathrm{Sr}$ & 1.33 \\
\hline Te & 1.71 \\
\hline Tc & 2.39 \\
\hline Th & $1.04 \times 10^{-5}$ \\
\hline $\mathbf{U}$ & 700 \\
\hline $\mathbf{X e}$ & 12.8 \\
\hline $\mathbf{Y}$ & 0.726 \\
\hline $\mathbf{Z r}$ & 119 \\
\hline Total fuel waste & 1128 \\
\hline HT-9 SS (cladding segments containing fuel) & 376 \\
\hline HT-9 SS (plenums and end plugs) & 665 \\
\hline 316 SS (duct, sockets, end pieces, and lower end plugs) & 2649 \\
\hline Total mass & 4818 \\
\hline Total watts, $2 y$ & 21701 \\
\hline
\end{tabular}




\subsubsection{Electrochemical Salt}

During the process, used salt is removed and replaced with fresh salt in a feed-and-bleed method. The rate at which salt is discharged is dependent on the limits of the useful service life of the salt, which may be controlled by 1 ) the concentration of sodium (from bond sodium in the metal fuel), which will change the liquidus temperature of the salt and may change the process efficiency, 2) the concentrations of lanthanide chlorides $\left(\mathrm{LNCl}_{3}\right)$, which may begin to contaminate the TRU product at sufficiently high concentrations, and 3) the high-heat fission products (i.e., $\mathrm{CsCl}$ and $\mathrm{SrCl}_{2}$ ), which may alter the performance of the salt bath.

Currently, concentration limits for sodium, lanthanides, and high-heat físsion products are not well defined and will require additional research to optimize the useful service life of salt. Several estimates of possible concentration limits have been made, but care must be made to compare these estimates on a similar concentration basis. Simpson et al. (2007) assumed a total fission product limit of 20 mass\% and sodium limit of $30 \mathrm{~mol} \%$ of the salt. Fredrickson (2014) estimated, on an actinide-free basis, a sodium chloride concentration of about 22 mass $\%$ ( 8.5 mass $\% \mathrm{Na}$ ), and total fission product chloride limit of about 25 mass $\%$ (16 mass\% total Cl-free FP).

Williamson (2014) estimated the "equilibrium" electrochemical salt composition shown in Table 1.13. Note that this equilibrium composition contains only about two-thirds of the Na and total FPs estimated by Fredrickson (2014), after accounting for all dissolved FPs and actinides. Table 1.13 also shows the calculated salt compositions after salt treatment steps, including actinide drawdown, actinide and LN drawdown, actinide and LN drawdown and selective crystallization, and actinide drawdown.

Many options are available for management of salt once the eventual limits are exceeded in the electrorefiner and after actinide drawdown. A few being considered in this report are:

1) Directly immobilize the salt for disposal with no further treatment (the baseline process for INL processing of DOE sodium bond fuel)(Simpson and Sachdev 2008, Priebe and Bateman 2008, Priebe 2007, Morrison et al. 2010, Morrison and Bateman 2010)

2) Drawdown the LN content of the salt by electrolysis (Williamson and Willit 2011)

3) Precipitate LN oxides by oxygen sparging (Frank 2011, Choi et al. 2014)

4) Precipitate LN as phosphates (Volkovich et al. 2003)

5) Ion exchange active físsion product in zeolite (Ackerman et al. 1997, Pereira et al. 1999, Simpson et al. 2007, Simpson 2013)

6) Concentrate fission products by selective crystallization (Simpson et al. 2013)

7) Selectively remove $\mathrm{CsCl}$ and $\mathrm{SrCl}_{2}$ by ion-selective membranes (Spoerke et al. 2013, Spoerke et al. 2014).

The LN removal may be coupled with one of the other purification processes. As there are such a large number of potential combinations of salt management processes and insufficient data on each process to have confidence in the resulting salt compositions, it's impractical to try and tabulate all potential salt stream compositions in this report. 
Table 1.13. Example Salt Compositions (mass\% component and total $\mathrm{kg} / \mathrm{tHM}$ )

\begin{tabular}{|c|c|c|c|c|}
\hline Component & $\begin{array}{c}\text { "Nominal" ER } \\
\text { salt }\end{array}$ & $\begin{array}{l}\text { Salt after } \\
\text { actinide } \\
\text { drawdown }\end{array}$ & $\begin{array}{c}\text { Salt after LN } \\
\text { drawdown }\end{array}$ & $\begin{array}{l}\text { Salt after LN } \\
\text { drawdown and } \\
\text { selective } \\
\text { crystallization }\end{array}$ \\
\hline LiCl & 31.56 & 33.91 & 36.41 & 19.80 \\
\hline KCl & 40.17 & 43.16 & 46.34 & 25.20 \\
\hline Total LiCl/KCl & 71.74 & 77.07 & 82.75 & 45.00 \\
\hline $\mathrm{UCl}_{3}$ & 1.76 & 0.00 & 0.00 & 0.00 \\
\hline $\mathrm{NpCl}_{3}$ & 0.12 & 0.00 & 0.00 & 0.00 \\
\hline $\mathrm{PuCl}_{3}$ & 4.13 & 0.00 & 0.00 & 0.00 \\
\hline $\mathrm{AmCl}_{2}$ & 0.53 & 0.00 & 0.00 & 0.00 \\
\hline $\mathrm{CmCl}_{3}$ & 0.19 & 0.00 & 0.00 & 0.00 \\
\hline Total actinide chlorides & 6.74 & 0.00 & 0.00 & 0.00 \\
\hline $\mathrm{NaCl}$ & 10.55 & 11.33 & 12.16 & 35.55 \\
\hline $\mathbf{R b C l}$ & 0.13 & 0.14 & 0.15 & 0.59 \\
\hline $\mathrm{SrCl}_{2}$ & 0.37 & 0.40 & 0.43 & 1.69 \\
\hline $\mathrm{CsCl}$ & 2.13 & 2.29 & 2.46 & 9.76 \\
\hline $\mathrm{BaCl}_{2}$ & 0.94 & 1.01 & 1.09 & 3.86 \\
\hline Total Group I, II chlorides & 14.29 & 15.17 & 16.29 & 51.45 \\
\hline $\mathbf{Y C l}_{3}$ & 0.23 & 0.25 & 0.00 & 0.00 \\
\hline $\mathrm{LaCl}_{3}$ & 0.89 & 0.95 & 0.00 & 0.00 \\
\hline $\mathrm{CeCl}_{3}$ & 1.66 & 1.78 & 0.00 & 0.00 \\
\hline $\mathrm{PrCl}_{3}$ & 0.83 & 0.89 & 0.00 & 0.00 \\
\hline $\mathrm{NdCl}_{3}$ & 2.58 & 2.77 & 0.00 & 0.00 \\
\hline $\mathrm{PmCl}_{3}$ & 0.12 & 0.13 & 0.00 & 0.00 \\
\hline $\mathrm{SmCl}_{2}$ & 0.74 & 0.79 & 0.85 & 3.19 \\
\hline Total lanthanide chlorides & 7.05 & 7.56 & 0.85 & 3.19 \\
\hline
\end{tabular}

\subsubsection{Metal Waste Stream}

The metal waste stream includes the stainless steel cladding (e.g., HT-9) and those components in the irradiated fuel that are more noble than uranium under the oxidation conditions used in the electrorefining operation. Table 1.14 lists the free energies of formation for chlorides of UNF components (NAS 2000), which provides a measure of the thermodynamic driver for oxidizing various metal elements in the waste. The stainless steel cladding along with $\mathrm{Cd}, \mathrm{Nb}, \mathrm{Mo}, \mathrm{Tc}, \mathrm{Rh}, \mathrm{Pd}, \mathrm{Se}, \mathrm{Te}$, and $\mathrm{Ru}$ remain as a metal. Because the electrorefiner is operated under conditions that efficiently oxidize and dissolve $U$, some of the $\mathrm{Zr}$ will be dissolved and partitioned between the metal and the salt; all other fuel components will dissolve in the salt.

The anode basket with the metal waste stream is removed from the ER and allowed to drain of salt. The salt will not totally be removed, so any adherent salt will need to be distilled off the metal waste. The distilled salt will be returned to the ER or be incorporated in the salt waste form. Table 1.15 lists the nominal metal waste stream composition electrochemical processing of the nominal fuel composition in Table 1.12 and after salt distillation (the HT-9 plenums and all 316SS components are excluded from this waste). The HT-9 stainless steel cladding accounts for $71.5 \%$ of the metal waste stream. 
Table 1.14. Free Energies of Formation of Chlorides $\left(-\Delta \mathrm{G}_{0}, \mathrm{kcal} / \mathrm{g}\right.$-eq at $\left.500^{\circ} \mathrm{C}\right)$ (from NAS 1995$)$

\begin{tabular}{|l|r|l|r|l|r|}
\hline $\begin{array}{l}\text { Elements that Remain } \\
\text { in Salt (very stable } \\
\text { chlorides) }\end{array}$ & $\begin{array}{l}\text { Elements that Can be } \\
\text { Electrotransported } \\
\text { Efficiently }\end{array}$ & \multicolumn{2}{l|}{$\begin{array}{l}\text { Elements that Remain } \\
\text { as Metals (less stable } \\
\text { chlorides) }\end{array}$} \\
\hline $\mathbf{B a C l}_{\mathbf{2}}$ & 87.9 & $\mathrm{CmCl}_{3}$ & 64 & $\mathrm{CdCl}_{2}$ & 32.3 \\
\hline $\mathbf{C s C l}$ & 87.8 & $\mathrm{PuCl}_{3}$ & 62.4 & $\mathrm{FeCl}_{2}$ & 29.2 \\
\hline $\mathbf{R b C l}$ & 87 & $\mathrm{AmCl}_{3}$ & 62.1 & $\mathrm{NbCl}_{5}$ & 26.7 \\
\hline $\mathbf{K C l}$ & 86.7 & $\mathrm{NpCl}_{3}$ & 58.1 & $\mathrm{MoCl}_{4}$ & 16.8 \\
\hline $\mathbf{S r C l}$ & 84.7 & $\mathrm{UCl}_{3}$ & 55.2 & $\mathrm{TcCl}_{4}$ & 11 \\
\hline $\mathbf{L i C l}$ & 82.5 & $\mathrm{ZrCl}_{4}$ & 46.6 & $\mathrm{RhCl}_{3}$ & 9 \\
\hline $\mathbf{N a C l}$ & 81.2 & & & $\mathrm{PdCl}_{2}$ & 6 \\
\hline $\mathbf{C a C l}$ & 80.7 & & & $\mathrm{RuCl}_{4}$ & \\
\hline $\mathbf{L a C l}_{3}$ & 70.2 & & & & \\
\hline $\mathbf{P r C l}_{3}$ & 69 & & & & \\
\hline $\mathbf{C e C l}_{3}$ & 68.6 & & & & \\
\hline $\mathbf{N d C l}_{3}$ & 67.9 & & & & \\
\hline $\mathbf{Y C l}_{3}$ & 65.1 & & & & \\
\hline
\end{tabular}

Table 1.15. Nominal Metal Waste Stream Composition, kg/tHM

\begin{tabular}{|c|c|c|c|}
\hline Component & \begin{tabular}{|l|} 
HT-9 \\
Contribution \\
\end{tabular} & $\begin{array}{l}\text { Fuel (FP and } \mathrm{Zr}) \\
\text { Contribution } \\
\end{array}$ & \begin{tabular}{|l|}
$\begin{array}{l}\text { Metal Waste } \\
\text { Stream }\end{array}$ \\
\end{tabular} \\
\hline $\mathbf{F e}$ & 318 & & 318 \\
\hline $\mathrm{Cr}$ & 43.7 & & 43.7 \\
\hline $\mathrm{Zr}$ & & 119 & 119 \\
\hline Mo & 4.51 & 9.07 & 13.6 \\
\hline Mn & 2.44 & & 2.44 \\
\hline W & 1.99 & & 1.99 \\
\hline $\mathrm{Ni}$ & 1.58 & & 1.58 \\
\hline$\underline{S i}$ & 1.20 & & 1.20 \\
\hline $\mathbf{V}$ & 1.17 & & 1.17 \\
\hline Ru & & 8.62 & 8.62 \\
\hline C & 0.79 & & 0.79 \\
\hline Pd & & 6.45 & 6.45 \\
\hline $\mathbf{R h}$ & & 2.96 & 2.96 \\
\hline Tc & & 2.39 & 2.39 \\
\hline Ag & & 0.645 & 0.645 \\
\hline Te & & 0.342 & 0.342 \\
\hline Sn & & 0.335 & 0.335 \\
\hline Sb & & 0.102 & 0.102 \\
\hline $\mathbf{U}$ & & $7.00 \times 10^{-2}$ & $7.00 \times 10^{-2}$ \\
\hline Pu & & $1.77 \times 10^{-2}$ & $1.77 \times 10^{-2}$ \\
\hline Am & & $9.25 \times 10^{-4}$ & $9.25 \times 10^{-4}$ \\
\hline $\mathrm{Cm}$ & & $3.79 \times 10^{-4}$ & $3.79 \times 10^{-4}$ \\
\hline Np & & $2.06 \times 10^{-4}$ & $2.06 \times 10^{-4}$ \\
\hline Nb & & $5.58 \times 10^{-5}$ & $5.58 \times 10^{-5}$ \\
\hline Total & 376 & 150 & 526 \\
\hline
\end{tabular}




\subsubsection{Electrochemical Process Off-Gas}

The requirements to manage the volatile radionuclides will be the same for the echem process as for the aqueous-based processes. However, the bulk of the iodine is expected to remain in the salt and not volatilize to the cell. The requirements for krypton capture imposed by 40 CFR 190 will require similar decontamination factors as described in Section 1.1.4. The current design of the processing equipment allows the release of volatile components to the cell atmosphere. This release then requires the treatment of a slip stream from the cell gas to be processed. It is assumed that the cell atmosphere is argon. Similar approaches to the recovery of krypton should be viable for this application. These include cryogenic recovery of krypton and the use of solid sorbents. Detailed descriptions of these $\mathrm{Kr}$ recovery processes are presented in Section 2.3 and are not repeated here. The concentration of $\mathrm{Kr}$ in the cell atmosphere will be a function of the processing rate of the slipstream and the rate of fuel processed. Based on the boiling points and melting points of the elements of interest, it would appear that cryogenic recovery processes would be comparable to those for $\mathrm{Kr}$ recovery from a nitrogen stream. The cryogenic recovery of krypton from the argon cell atmosphere would not require the catalytic removal of oxygen as is the case with krypton recovery from an air stream. A Kr DF of 100 is assumed. The $\mathrm{Kr}$ recovery technology may require some adaptation for argon cells to account for large amount of Ar compared to the $\mathrm{Kr}$ in the slip stream.

The amount of ${ }^{3} \mathrm{H}$ in the fuel is uncertain. Significant fractions of the ${ }^{3} \mathrm{H}$ generated from ternary fission are known to be released during reactor operation. It is assumed that recovery of ${ }^{3} \mathrm{H}$ released to the cell would be required and would be comparable to the recovery of ${ }^{3} \mathrm{H}$ from the TPT. This would involve the catalytic oxidation of ${ }^{3} \mathrm{H}$ to ${ }^{3} \mathrm{H}_{2} \mathrm{O}$ by the addition of oxygen to a small slipstream that is recycled back to the cell. The system should be designed for a DF of 100. The tritiated water is captured on a MS3A and managed as described in Section 7.2.

Unpublished studies of the mark-IV ER operation have shown that iodine is very stable in the ER salt. However, the metal drawdown processes for actinides and potentially lanthanides will evolve $\mathrm{Cl}_{2}$ gas. Chlorine gas evolved during these processes is captured in a getter and discharged as waste. It is possible that $I_{2}$ gas will also be liberated by these processes. Any $I_{2}$ evolved during the process would also be collected in the $\mathrm{Cl}_{2}$ scrubber system and discarded as waste. It is suspected that $\mathrm{I}_{2}$ would be released proportionally to that of the $\mathrm{Cl}_{2}$. The overall $\mathrm{I}_{2} \mathrm{DF}$ for the plant will need to be between 1000 and 3000 . The fraction retained in the salt will reduce the demand on the getter system.

Carbon-14 is not believed to be an issue as it will either partition to the salt phase or remain with the noble metals. 


\section{OFF-GAS TREATMENT WASTE STREAMS}

During the processing of used fuel, volatile radionuclides need to be captured and managed so that facility discharges do not exceed regulatory limits during normal operation and predictable off-normal events. The volatile radionuclides of concern are ${ }^{3} \mathrm{H},{ }^{14} \mathrm{C},{ }^{85} \mathrm{Kr}$, and ${ }^{129} \mathrm{I}$. The chemical and physical form, impurity concentrations, and specific handling requirements of the volatile waste streams are directly determined by the capture methods deployed. Therefore, component capture and waste management are considered in a holistic fashion for the four primary volatile radionuclides. Off-gas treatment systems and volatile waste management approaches have been systematically evaluated in support of the GNEP program (Gombert et al. 2007 and 2008; AFCF 2007; CFTC 2008). The evaluations include process selection, equipment selection and scaling, waste form generation rate estimates, capital and operating cost estimates, and descriptions of the state of technology development/demonstration and associated technical gaps. Since those evaluations, significant additional research and analyses have been conducted. This research includes the filling of technical gaps as well as the initial development of innovative approaches that show some promise to perform better than the baseline approaches selected for GNEP. In this section, the conclusions of the GNEP program studies are summarized with the results of research performed since those studies; and reference waste management strategies are recommended and current technology gaps for further research are summarized.

The off-gas treatment and waste management technologies discussed in the sections that follow are based on the separations processes described in Sections 1.1 and 1.2, above.

\subsection{Tritium}

Tritium is generated in LWR fuel from ternary fission and activation of ${ }^{2} \mathrm{H}$ and ${ }^{10} \mathrm{~B}$ in cooling water (a fraction of which is contained in the hulls as zirconium hydride). The reference volatile gas source terms are based on ORIGEN (Croff 1983) data for PWR fuel at a burn-up of $50 \mathrm{GWd} / \mathrm{tHM}$. It should be noted that BWR fuel may contain higher concentrations of ${ }^{3} \mathrm{H}$. The half-life of ${ }^{3} \mathrm{H}$ is sufficiently small (12.26 y) that the inventory is highly dependent on cooling time as shown in Figure 2.1, but for cooling times less than roughly 70 years, controls are needed.

Tritium is not captured nor treated with current generation reprocessing plants (aqueous methods practiced commercially and electro-chemical methods practiced at INL). Tritium is currently released to the environment via atmospheric or waste water discharges. Direct discharge of ${ }^{3} \mathrm{H}$ is not anticipated to be an appropriate disposition path for a U.S. reprocessing plant (Jubin et al. 2013). The DF requirement for tritium ranges from roughly 100 at $5 \mathrm{y}$ cooling to roughly 7 at $50 \mathrm{y}$ cooling to 1 at roughly $70 \mathrm{y}$ cooling (Jubin et al. 2012b). Likewise, the ${ }^{3} \mathrm{H}$ waste form, assuming ${ }^{3} \mathrm{H}$ is the only radionuclide of concern in the waste form, needs to be protective of the environment for only $70 \mathrm{y}$. Tritium in zirconiumclad LWR fuel is found split between the fuel meat and the cladding. The fraction contained in the cladding may range from 0 to $78 \%$ (Robinson and Jubin 2013). In the case where the cladding is not treated, only the fraction in the fuel meat must be managed. 


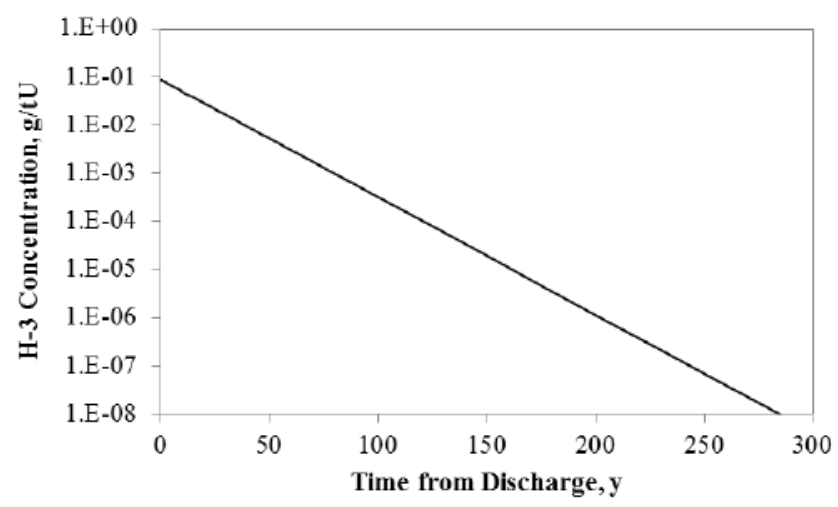

Figure 2.1. Concentration of ${ }^{3} \mathrm{H}$ in Typical $50 \mathrm{GWd} / \mathrm{tU}$ PWR Fuel as a Function of Time from Discharge.

\subsubsection{Tritium Recovery}

Two basic approaches for managing ${ }^{3} \mathrm{H}$ are considered in this report:

1) Fuel is chopped and dissolved with the ${ }^{3} \mathrm{H}$ partitioning primarily to the dissolved fuel solution and ultimately managed in a high-volume aqueous waste stream.

2) Tritium pretreatment (TPT) is applied to remove ${ }^{3} \mathrm{H}$ from the fuel meat to the TPT off-gas treatment (TOG) system and managed in a low-volume gas stream.

Tritium management for case (1) is described in detail in Section $6,{ }^{3} \mathrm{H}$ management for case (2) is described in this subsection.

The GNEP studies assumed TPT process to remove ${ }^{3} \mathrm{H}$ prior to dissolution. The reference TPT process for GNEP and this study is based on a calcination of the clad fuel segments in flowing dry air (dew point of $\left.-60{ }^{\circ} \mathrm{C}\right)$ at $500{ }^{\circ} \mathrm{C}$, although other oxidants $\left(\mathrm{O}_{2}, \mathrm{O}_{3}, \mathrm{NO}_{2}\right)$ and temperatures $\left(450\right.$ to $650{ }^{\circ} \mathrm{C}$ in standard practice; 200 to $250{ }^{\circ} \mathrm{C}$ for $\mathrm{NO}_{2}$ TPT; 950 to $1200^{\circ} \mathrm{C}$ for high-temperature voloxidation) have been tested and may have advantages (Goode and Stacy 1978, Goode et al. 1980, Spencer et al. 1983, Uchiyama et al. 1992, Song et al. 2008, Spencer and DelCul 2010, Jeon et al. 2012, Johnson et al. 2013). The fraction of each of the key radionuclides released during standard dry air TPT at $500{ }^{\circ} \mathrm{C}$ are listed in Table 1.2.

Tritiated water (HTO) may be removed from the off-gas stream with desiccants or molecular sieves. To ensure that all ${ }^{3} \mathrm{H}$ released from the fuel is converted to water, which facilitates ${ }^{3} \mathrm{H}$ recovery, the off-gas stream may be routed through a heated copper catalytic combiner. However, the catalytic combiner is not included in this study: 1) the TPT process oxidizes hydrogen to HTO so the combiner is likely unnecessary and 2) the copper catalyst is likely to absorb radioiodine.

Anhydrous $\mathrm{CaSO}_{4}$ and silica gel are possible desiccants. Molecular sieves exhibit high water capacities; 10 to 20 mass $\%$ based on the dry weight of the sorbent. The molecular sieve MS3A was selected as the reference water removal media for both the GNEP and this study based on high capacity, relatively high technical maturity, and ease of regeneration (as summarized in Table 2.1). However, the MS3A also captures $\mathrm{CO}_{2}$ (Rivera et al. 2003) and $\mathrm{I}_{2}$ (Holland 1979 and Spencer et al. 2013) at temperatures significantly below room temperature. There are variations in performance characteristics of the material obtained from different manufactures as evidenced by differences in the elution temperature for $\mathrm{CO}_{2}$. The coadsorption of ${ }^{3} \mathrm{H}$ and ${ }^{129} \mathrm{I}$ on both the ${ }^{3} \mathrm{H}$ filter and on the iodine filter make the design of the HOG control system challenging (Spencer et al. 2013). Even small concentrations of ${ }^{129} \mathrm{I}$ will result in a ${ }^{3} \mathrm{H}$ waste form that exceeds Class-C limits $\left(0.08 \mathrm{Ci} / \mathrm{m}^{3}\right.$ for $\left.{ }^{129} \mathrm{I}\right)(10 \mathrm{CFR} 61.55)$. Tritium sorbed on the ${ }^{129} \mathrm{I}$ media is released during thermal processing to make the final iodine waste form, requiring recapture and 
management of the evolved ${ }^{3} \mathrm{H}$. This challenge was identified, but unsolved, during the GNEP studies. Spencer et al. (2013) characterized the issue and developed a flowsheet capable of effective management of both ${ }^{129} \mathrm{I}$ and ${ }^{3} \mathrm{H}$ from TOG. The iodine absorber first removes iodine and some of the ${ }^{3} \mathrm{H}$ from the TOG followed by the MS3A tritiated water trap. The water sorbed on the iodine trap can then be desorbed by flowing dry air at an elevated temperature prior to iodine waste form fabrication. Continuing in this manner appears to make a clean separation of iodine to AgZ and water to MS3A (Spencer et al. 2013). Figure 1.4 shows a schematic of the HOG.

Table 2.1. Tritium Recovery Step: Molecular Sieves (MS3A)

\begin{tabular}{|l|l|}
\hline \multicolumn{1}{|c|}{ Process Conditions } & \multicolumn{1}{c|}{ Temperature $25^{\circ} \mathbf{C}$} \\
\hline Removal Efficiencies & Drying to $-50^{\circ} \mathrm{C}$ dew point \\
\hline Capacity of Adsorbent & 0.11 to $0.16 \mathrm{~kg} / \mathrm{kg}$ \\
\hline Level of Development & $\begin{array}{l}\text { Extensive industrial use in non-nuclear applications } \\
\text { Some uses in nuclear applications }\end{array}$ \\
\hline Regeneration & $270^{\circ} \mathrm{C}$ for roughly 30 cycles \\
\hline
\end{tabular}

Prior to ${ }^{3} \mathrm{H}$ breakthrough, the MS3A filter is exchanged. The loaded filter can be regenerated by heating to $270{ }^{\circ} \mathrm{C}$ with flowing $\mathrm{N}_{2}$ to release tritiated water that is condensed to a liquid for waste management. The regenerated filter is returned to service. Alternatively, the media can be directly disposed.

The amount of ${ }^{3} \mathrm{H}$ in the waste from the example fuel (50 GWd/tU PWR fuel cooled between 5 and $\left.50 \mathrm{y}\right)$ will range from 3.9 to $48 \mathrm{mg} / \mathrm{tU}$ (not including $25 \%$ of the total ${ }^{3} \mathrm{H}$ assumed to remain in the cladding). For systems operating at pressures near one atmosphere, such as the tritium pretreatment equipment, the dew point concentration of water vapor over the molecular sieve is close to, or lower than, the concentration obtained when the only source of water in the off-gas is from hydrogen in the fuel. Water needs to be intentionally bled into the process to obtain appropriate decontamination factors. Usually the air fed to the TPT equipment to oxidize the fuel contains water vapor and the concentration can be augmented if necessary. It has been estimated that the amount of $\mathrm{H}_{2} \mathrm{O}$ from low humidity air would increase the amount of tritiated water by 4 to $7 \times$ (assuming $-60^{\circ} \mathrm{C}$ dewpoint air used in TPT). The deliberate addition of water into the TPT off-gas has been suggested as a possible requirement to ensure efficient recovery of the tritiated water. This could increase the waste volume by another factor of 10 . This assessment will assume a total tritiated water volume of $50 \times$ the expected concentration of ${ }^{3} \mathrm{H}_{2} \mathrm{O}$ from the fuel or 1.89 and $23.6 \mathrm{~g} / \mathrm{tU}$ tritiated water, for 50 or 5 year cooled fuel, respectively.

The molecular sieve traps need to be sized to capture not only the water arising from hydrogen isotopes released from the fuel, but also the water vapor carried by the feed gas and in-leakage streams. The water loading capacity of the molecular sieves is about $0.11-0.16 \mathrm{~g} / \mathrm{g}$.

\subsubsection{Tritium Immobilization}

As stated earlier, the short half-life of ${ }^{3} \mathrm{H}$ means that a waste form lasting only $100 \mathrm{y}$ is sufficient to immobilize it. Several waste forms were evaluated for the tritiated water:

1) The loaded MS3A without regeneration.

2) $\mathrm{CaSO}_{4}$ desiccant.

3) Solid absorber (clay or vermiculite).

4) Cement for tritiated water waste stream only.

5) Cement for combined waste streams including tritiated. 
These approaches are discussed in Section 7.2.

\subsection{Iodine}

As stated earlier, the capture and immobilization of gaseous fission products are practically linked. A brief review of iodine separations methods therefore prefaces the discussion on ${ }^{129} \mathrm{I}$ waste forms. Iodine separation is performed at a number of different points in an aqueous separations plant process: HOG, DOG, VOG, potentially cell off-gas (COG), and MOG. These off-gas streams have different flow rates and compositions and have different gaseous radionuclide control requirements, depending on how the gaseous radionuclides partition (Jubin et al. 2013). Table 2.2 summarizes the fraction of ${ }^{129}$ I partitioned to various plant off-gas streams. The iodine released is generally of the form of $\mathrm{I}_{2}(90$ to $100 \%)$ and organic iodides (e.g., $\mathrm{CH}_{3} \mathrm{I}, \mathrm{C}_{2} \mathrm{H}_{5} \mathrm{I}$, and $\left.\mathrm{C}_{4} \mathrm{H}_{9} \mathrm{I}\right)(0$ to $10 \%$ ). Up to $85 \%$ of the iodine found in the VOG streams was bound to organic compounds (Herrmann et al. 1990; Psarros et al. 1990).

Table 2.2. Ranges of Estimated Iodine Partitioning between Various Off-Gas Streams

\begin{tabular}{|l|l|l|l|l|}
\hline Location & $\begin{array}{l}\text { Percent of Iodine } \\
\text { Inventory }\end{array}$ & $\begin{array}{l}\text { I Concentration in } \\
\text { Stream }\left(\mathbf{m g} / \mathbf{m}^{\mathbf{3}}\right)\end{array}$ & $\begin{array}{l}\text { Total Flowrate } \\
\left(\mathbf{m}^{\mathbf{3}} / \mathbf{h}\right)\end{array}$ & Reference \\
\hline $\begin{array}{l}\text { Shear cell } \\
\text { off-gas }\end{array}$ & 0.15 to 0.30 & 3 to $18 \times 10^{-3}$ & 7300 & Herrmann et al. 1993 and 1997 \\
\hline $\begin{array}{l}\text { TOG (if } \\
\text { used) }\end{array}$ & 0.1 to 1 & 800 & 0.5 to 2.5 & $\begin{array}{l}\text { Goode and Stacy 1978; Goode et al. } \\
1980 ; \text { Shaffer 1983; Spencer and } \\
\text { DelCul 2010 }\end{array}$ \\
\hline DOG & 94 to 99 & 1200 to 6000 & 280 & See summary in Jubin et al. 2013 \\
\hline UDS & 0 to 6 & $\mathrm{n} / \mathrm{a}$ & $\mathrm{n} / \mathrm{a}$ & $\begin{array}{l}\text { Sakurai et al. 1991, 1992, 1997; } \\
\text { Mineo 2002 }\end{array}$ \\
\hline VOG & 1 to 2.5 & 1 to 30 & 270 to 3000 & \\
\hline MOG & 0.1 to 1 & 0.1 & 200 & Goles et al. 1981, 1992 \\
\hline
\end{tabular}

\subsubsection{Iodine Separations Technologies}

Several reviews on ${ }^{129}$ I recovery technology have been published (Holladay 1979, Jubin 1979, Hebel and Cottone 1982, Brown et al. 1983, Burger and Scheele 1983, IAEA 1987, Jubin 1988, Goosens et al. 1991, Haefner and Tranter 2007, Gombert et al. 2008, Paviet-Hartman et al. 2011, IAEA 2014). Technologies have been developed for the recovery of airborne ${ }^{129} \mathrm{I}$ based on scrubbing with caustic or acidic solutions and chemisorption on silver-coated or impregnated adsorbents. It is not the intent of this report to cover in detail the results in those studies, but only summarize their findings.

\subsubsection{Silver Adsorbents}

Various types of adsorbents for iodine have been studied and developed over the years. Natural or artificial porous material like zeolite, mordenite, alumina, and silica gels have been loaded with metals (such as $\mathrm{Ag}, \mathrm{Cd}, \mathrm{Pb})$ and/or the metal nitrate $\left(\mathrm{AgNO}_{3}\right)$, and used in performance studies. Commercially available inorganic sorbent materials include silver-exchanged faujasite $(\mathrm{AgX})$, and mordenite $(\mathrm{AgZ})$ and silver-impregnated silicic acid (AC-6120).

The development of $\mathrm{AgX}$ and $\mathrm{AgZ}$ was conducted primarily in the United States and has not advanced beyond laboratory tests for ${ }^{129}$ I recovery. Published literature surveyed by Thomas et al. (1977) indicated iodine loadings ranging from 80 to $200 \mathrm{mg}$ per gram of $\mathrm{AgX}$ or $\mathrm{AgZ}$ while maintaining decontamination factors in the range of 100 to 10000 for elemental iodine. While effective in removing iodine from gas 
streams, the $\mathrm{AgX}$ substrate decomposes in the presence of $\mathrm{NO}_{\mathrm{x}}$ and water vapor. Therefore, a more acid resistant substrate was desirable for use in the DOG application.

The AgZ sorbent has been developed specifically for application in DOG streams because of its high acid resistance. Elemental iodine loadings of $170 \mathrm{mg}$ per gram of Norton Zeolon $900 \mathrm{AgZ}$ and typical methyl iodide $\left(\mathrm{CH}_{3} \mathrm{I}\right)$ loadings of 140 to $180 \mathrm{mg}$ per gram of substrate have been obtained for tests on simulated DOG streams. An initial study of the mechanisms for $\mathrm{CH}_{3} \mathrm{I}$ adsorption into $\mathrm{AgZ}$ was recent completed. It is shown that the zeolite catalytically cleaves the $\mathrm{CH}_{3}$ - and $-\mathrm{I}$ and then captures the iodine by forming AgI in the pores of the zeolite (Nenoff et al. 2014a). The resultant AgIZ is shown to be stable to this waste stream; organic byproducts (e.g., methanol, dimethyl ether) are easily removed from the zeolite surface with flowing gas and mild heat.

Studies were undertaken at Idaho National Engineering Laboratory (INEL) to find a method to regenerate the filter bed thus reducing the quantity of silver lost to the waste stream. This work (Thomas et al. 1977; Slansky et al. 1976) showed that regeneration in high temperature $\left(400-500^{\circ} \mathrm{C}\right)$ hydrogen was possible. Burger and Scheele (1982) also indicated that recycle of the AgZ was possible, but they found variable process performance and iodine removal that declined with repeated cycles. Because of the low trapping efficiency of $\mathrm{PbX}$, iodine circulates through the system, corroding the $\mathrm{H}_{2}$ pump. The final report on $\mathrm{AgZ}$ development from INEL (Murphy et al. 1977) reported that an AgZ bed had been loaded with $\mathrm{I}_{2}$ and recycled 13 times with a $20 \%$ loss in capacity compared to the initial loading.

The most extensive development and application of iodine adsorbents have been with AC-6120 (Furrer et al. 1984; Herrmann et al. 1988; Maurel and Vigla 1987; Modolo and Odoj 1997; Sakurai and Takahashi 1994). For the WAK, AC-6120 was developed to the prototype stage for application with the DOG. The DOG passes through an $\mathrm{NO}_{2}$ absorption column and high efficiency particulate air (HEPA) filter before entering the iodide trap. Since 1975, adsorbent beds have been used to recover ${ }^{129} \mathrm{I}$ with DFs $>1000$. Some of the operating and design parameters include those used by Wilhelm et al. (1976); in the early filters, $26 \mathrm{~kg}$ of low-impregnation AC-6120 ( 7 mass\% Ag) was used at a flow rate of $148 \mathrm{~m}^{3} / \mathrm{h}$, residence time of $0.6-1.4 \mathrm{~s}$, an operating temperature of $130{ }^{\circ} \mathrm{C}$, and up to 2 volume $\%$ of $\mathrm{NO}_{\mathrm{x}}$ in the gas stream. Peak $\mathrm{NO}_{\mathrm{x}}$ concentrations of up to $20 \%$ were possible, DFs during the first 120 day service life ranged from $1.0 \times 10^{4}$ to $2.0 \times 10^{4}$. A high impregnation AC- $6120 \mathrm{H}$ material, which contains $\sim 12$ mass $\%$ $\mathrm{Ag}$, was not used in the initial iodine sorption filter at WAK because of limited availability at the time. The system was later modified to provide two filter drums in series. Up to $95 \%$ utilization of the AC6120 based on the formation of AgI was achieved in the primary filter drum and DFs over the period 1975 to 1985 were $>10^{4}$.

The AC6120H ( 12 mass\% Ag) sorbent was also tested on a side stream of the WAK VOG (Hermann et al. 1989). In this test, the iodine filter was operated for nearly one year on a $10 \%$ side-stream $\left(35 \mathrm{~m}^{3} / \mathrm{h}\right)$ from the main VOG stream with a DF $>50$. The filter was operated at $140^{\circ} \mathrm{C}$. This test showed a lower DF because of low concentration of iodine and a high fraction of organic iodide.

More recently, silver-functionalized silica aeorgels have been under development for the capture and immobilization of radioiodine (Matyas 2012a,b). This new silver absorber is attractive because of the high I capacity and potentially simple conversion to a highly durable fused silica composite waste form. Iodine capacities in the range of 45 mass\% were measured with DF's over 10000 for laboratory tests with simulated DOG gas streams (Matyas et al. 2011, Soelberg and Watson 2012). After aging in humid air at $150{ }^{\circ} \mathrm{C}$ the capacity reduction of roughly $20 \%$ was observed (Bruffey et al. 2013). This material is promising, but is at an early stage of development. 


\subsubsection{Charcoal / Activated Carbon}

Although activated carbon has been used successfully in power plants, it has several serious drawbacks for application in a nuclear reprocessing plant:

1. It has a relatively low ignition point; thus, without continuous air flow through the filter, the decay heat of trapped radioiodine could ignite the bed.

2. The bed has poor iodine retention at high temperatures and permits total iodine releases upon ignition.

3. The presence of nitrogen oxides adversely affects performance; nitrogen oxides can also lead to the production of explosive compounds within the filter bed

These factors led to the decision not to use this material in reprocessing plant off-gas systems in the past.

\subsubsection{Caustic Scrubbing}

Caustic scrubbing for ${ }^{129}$ I recovery has been applied at the Windscale, THORP, UP1, UP2 and Tokai reprocessing plants (Hebel and Cottone 1982; LAEA 1987). At the Windscale reprocessing plant, an iodine DF of 50 has been reported, while the other DFs are not reported. The organic iodides pass through the solution essentially unreacted, and $\mathrm{CO}_{2}$ and $\mathrm{NO}_{\mathrm{x}}$ deplete the scrubbing solution by forming carbonate and nitrates. Methods for immobilizing the waste were not developed.

The operating experience at the Tokai reprocessing plant indicates that, while the caustic scrubber in the DOG provides sufficient removal efficiency, that of the VOG scrubber is lower than expected. Organic compounds in the VOG stream appear to be the cause of the low DF value (IAEA 1987). The THORP plant utilizes a caustic scrubber to achieve an iodine DF of 100 (Hudson 1995). This same caustic scrubber is used to scrub $\mathrm{NO}_{\mathrm{x}}, \mathrm{Ru}_{\text {(gas) }}$, and ${ }^{14} \mathrm{C}$ with $\mathrm{DFs}$ of 100,100 , and 70 , respectively. Experimental work has demonstrated that the $\mathrm{NO}_{\mathrm{x}}$ evolved during the dissolution process is effective in maintaining the ${ }^{129} \mathrm{I}$ in the volatile molecular form. Because ${ }^{14} \mathrm{C}$ is simultaneously removed with the iodine in the caustic solution, an independent ${ }^{14} \mathrm{C}$ trapping technology could not be applied. This could complicate waste management with the requirement that a single approach would be required.

\subsubsection{Iodox}

The Iodox technology was developed for application to liquid-metal fast breeder reactor (LMFBR) fuel reprocessing where the spent fuel would have been processed within 180 days of leaving the reactor and would have required high DFs to control ${ }^{131}$ I releases $\left(>10^{4}\right)$ (Birdwell 1990; Burch et al. 1976; Clark et al. 1978; Collins and Benker 1979; Goumondy et al. 1981; Groenier and Hannaford 1975; Holladay 1979; Jubin and Lewis 1987; Kaneko et al. 1978; Kaneko et al. 1980; Kaneko et al. 1979; Mailen 1975, 1976; Yarbro et al. 1977). Decontamination factors up to $10^{6}$ were obtained in cold engineering tests. The method appeared to be equally efficient for both elemental and organic forms of iodine. A 20-22 M $\mathrm{HNO}_{3}$ in a bubble cap column was used to recover the iodine as $\mathrm{HI}_{3} \mathrm{O}_{8}$. The process required secondary steps to concentrate $13 \mathrm{M} \mathrm{HNO}_{3}$ to $22 \mathrm{M}$, recycle, concentrate acid diluted by moisture in the DOG, and concentrate the waste stream to the solid anhydroiodic acid (ERDA, 1976). Due to the highly corrosive nature of the hyperazeotropic nitric acid, the process equipment must be constructed of relatively expensive materials such as zirconium or titanium (IAEA 1987). The iodine may also be recovered as $\mathrm{Ba}\left(\mathrm{IO}_{3}\right)_{2}$.

Major advantages of the process are that no unusual chemicals are added to the reprocessing plant, both elemental and organic iodides are handled with high DFs, and the iodine products are suitable for conversion to a waste form without significant added volume. Major disadvantages are the capital cost 
associated with the materials of construction that are required (zirconium or titanium) and the need to add or produce the hyperazeotropic nitric acid (LAEA 1987).

\subsubsection{Mercurex}

This process was also developed for the treatment of the dissolver off-gas evolved during the processing of very short cooled fuels where large iodine DFs are required $\left(>10^{5}\right)$. The process used a mercuric nitrate - nitric acid solution in a packed or bubble cap column to recover the iodine as $\mathrm{HgI}_{2}$ and iodine complexes (Collard et al. 1981b; Palamalai et al. 1983; Wood and Richardson 1977). For elemental $\mathrm{I}_{2}$ and $\mathrm{CH}_{3} \mathrm{I}$, DFs of 1000 to 5000 and 100 respectively have been obtained at temperatures of $50{ }^{\circ} \mathrm{C}$. Mercurex was applied at an industrial scale at the Dounreay and Nuclear Fuel Services reprocessing plants with reported DFs of 150 and 32 for $\mathrm{I}_{2}$ and $\mathrm{CH}_{3} \mathrm{I}$, respectively (Hebel and Cottone 1982). Two scrubbers in series were installed in the Barnwell Nuclear Fuel Plant (BNFP). The DFs were claimed to be 10 and 75 (IAEA 1987).

Major advantages of the process are that no unusual materials of construction are required (stainless steel is suitable) and no special processes are required to produce the hyperazeotropic nitric acid. Major disadvantages are the toxic nature of the mercury involved and the probable need to convert the mercuryiodine compounds into a more suitable form for disposal (IAEA 1987) and relatively low DFs.

\subsubsection{Silver Reactors}

The Hanford PUREX Plant and the Savannah River Plant have for many years routinely used silver reactors to remove ${ }^{131}$ I from off-gas streams (Rodger and Reese 1969). The process involves passing the DOG through a bed of heated ceramic saddles glazed with silver nitrate and chemisorbing the iodine as silver iodide and iodate. Silver reactors have demonstrated DFs of 10 to $10^{4}$ for ${ }^{131}$ I recovery. When the silver reactor efficiency begins to fall, it can be regenerated up to 10 times by removing the accumulated material with an alkaline sodium hyposulfite wash solution, washing, and spraying the bed with a solution of $5 \underline{\mathrm{M}} \mathrm{AgNO}_{3}$.

The development of the silver reactors appeared to have specifically included long term retention or recovery of ${ }^{129} \mathrm{I}$ (they were solely to provide sufficient delay for the ${ }^{131} \mathrm{I}$ to decay before leaving the stack) and no method for immobilizing liquid waste from the process or bed change-out was examined. Strachan (1978) reported than an examination of some of the bed material in the silver reactor at Hartford showed that no ${ }^{129} \mathrm{I}$ had been retained by the reactor following several years of operation. The analysis indicated that virtually all the AgI that would have been formed had been converted to $\mathrm{AgCl}$ by a Clbearing species in the off-gas stream. Chlorine contaminants in the process chemicals were the likely sources of the chlorine.

\subsubsection{Metal Organic Frameworks}

Metal-organic frameworks (MOFs) are viewed by many as the next-generation of porous materials with promising applications in gas separations. These materials are excellent candidates for selective gas sorption for the following reasons: their ultrahigh capacity due to surface areas up to $6000 \mathrm{~m}^{2} / \mathrm{g}$, the tunability of adsorption by judicious choices of metal centers or organic ligands, and the design of pore sizes. Initial studies with ZIF-8 (2-methylimidazole zinc salt) framework for its size selective pore size (approximating $\mathrm{I}_{2}$ size) showed very strong sorption for $\mathrm{I}_{2}$. Iodine loadings of up to 125 mass\%, of which 110 mass\% is inside the pores under static conditions, have been observed for ZIF-8 (Sava et al. 2011). However, a sample of ZIF-8 was tested for iodine separation in flowing gas stream in a thin bed 
configuration (Jubin 2012). Three tests were performed with between 2.6 and 3.4 mass\% iodine uptake. sorption bed studies showed low loading levels due to slow sorption kinetics.

Subsequent studies with Cu-BTC (HKUST-1) a large pored MOF with accessible metal centers for direct $\mathrm{I}_{2}-\mathrm{Cu}$ interactions showed excellent loading of $\mathrm{I}_{2}$ (up to 150 mass $\%$ ) even in the presence of water vapor (Sava et al. 2013). This material class is very promising for fission gas capture, as it is being heavily studied worldwide for important fuel gases such as $\mathrm{H}_{2}, \mathrm{CO}_{2}$ and $\mathrm{CH}_{4}$ storage, but, remains in the early development stage for Iodine species. However, it has not yet been tested for iodine uptake in a dynamic (flowing) system.

\subsubsection{Summary}

A summary of iodine recovery processes is shown in Table 2.3. The GNEP studies selected AgZ as the most appropriate means of capturing iodine from all of the gas streams based on the high DF (for both $\mathrm{I}_{2}$ and organic iodides), high capacity, technical maturity, and tolerance to NOx (Gombert et al. 2007 and 2008; AFCF 2007; CFTC 2008; Carter et al. 2011). Since those studies were carried out, significant additional testing has been performed to fill the technical gaps they identified for AgZ including impact of aging (Bruffey et al. 2013b, 2014; Soelberg and Watson 2012; Jubin et al. 2012, 2013), coadsorption of tritium (discussed in Section 2.1), and waste form development (Garino et al. 2010, 2011, 2014; Nenoff et al. 2012, 2013a, 2013b). Also studied were alternative sorbents such as the Ag-Aero (Strachan et al. 2011b, Matyas et al. 2012) the chalcogenide aerogel (Riley and Lepry 2012; Riley et al. 2012, 2013, 2014), and the MOF (Sava et al. 2011, 2013). The results of these studies suggested that the AgZ should be the reference capture method and additional research should be performed to determine if Agfunctionalized silica aerogel gives significant advantages and, if so, to increase its technology readiness through testing and demonstration.

Table 2.3. Iodine Recovery Process Comparison

\begin{tabular}{|c|c|c|c|c|c|}
\hline $\begin{array}{c}\text { Material / } \\
\text { Process }\end{array}$ & Process Conditions & $\begin{array}{c}\text { Decontamination } \\
\text { Factor } \\
\end{array}$ & $\begin{array}{c}\text { Capacity of } \\
\text { Adsorbent } \\
\end{array}$ & $\begin{array}{c}\text { Level of } \\
\text { Development }\end{array}$ & Regeneration \\
\hline $\operatorname{AgX}$ & $\begin{array}{l}\text { Preheating of inlet gas } \\
\text { to } 150^{\circ} \mathrm{C} \\
\text { Operating Temp } 150^{\circ} \mathrm{C} \\
\mathrm{NO}_{\mathrm{x}} \text { removal needed }\end{array}$ & $10-10^{4}$ & $80-200 \mathrm{mg} \mathrm{I} / \mathrm{g}$ & $\begin{array}{l}\text { Laboratory scale } \\
\text { studies } \\
\text { Prototype and } \\
\text { large-scale } \\
\text { application }\end{array}$ & $\begin{array}{c}\text { Not stable ( } 50 \% \\
\text { loss in capacity } \\
\text { after } 5 \text { cycles) }\end{array}$ \\
\hline $\mathrm{AgZ}$ & $\begin{array}{l}\text { Preheating of inlet gas } \\
\text { to } 100-200^{\circ} \mathrm{C} \\
\text { Operating Temp } 100- \\
200{ }^{\circ} \mathrm{C} \\
\text { Pretreat } \mathrm{AgZ} \text { with } \\
\text { hydrogen to improve } \\
\text { loadings }\end{array}$ & $10-10^{4}$ & $\begin{array}{l}140-180 \mathrm{mg} \mathrm{I}_{2} / \mathrm{g} \\
\text { Norton Zeolon } \\
900 \mathrm{AgZ} \\
230 \mathrm{mg} \mathrm{I} / \mathrm{g} \mathrm{AgZ} \\
\mathrm{max} \\
60-100 \mathrm{mg} \mathrm{I} / \mathrm{g} \\
\text { currently } \\
\text { produced } \mathrm{AgZ} \\
\text { Laboratory } \\
\text { regeneration of } \\
\text { beds has been } \\
\text { demonstrated. }\end{array}$ & $\begin{array}{l}\text { Laboratory scale } \\
\text { studies }\end{array}$ & $\begin{array}{l}400 \text { to } 500{ }^{\circ} \mathrm{C} \text { with } \\
\mathrm{H}_{2}(20 \% \text { loss in } \\
\text { capacity after } 13 \\
\text { cycles) }\end{array}$ \\
\hline AC- 6120 & $\begin{array}{l}\text { Preheating of inlet gas } \\
\text { to } 130-140{ }^{\circ} \mathrm{C} \\
\text { Operating Temp } 130- \\
140{ }^{\circ} \mathrm{C} \\
\mathrm{NO}_{\mathrm{x}} \text { tolerant }\end{array}$ & $1000-10^{4}$ & $\begin{array}{l}143 \mathrm{mg} \mathrm{I} / \mathrm{g}(\max ) \\
\text { for } \mathrm{AC}-6120 / \mathrm{H} \\
(12 \% \mathrm{Ag}) \\
\text { Up to } 95 \% \text { silver } \\
\text { utilization has } \\
\text { been achieved }\end{array}$ & $\begin{array}{r}\text { Prototype and } \\
\text { large-scale } \\
\text { application }\end{array}$ & \\
\hline Ag-Aero & $\begin{array}{l}\text { Preheating of inlet gas } \\
\text { to } 150^{\circ} \mathrm{C}\end{array}$ & $\begin{array}{l}10^{4} \text { for } I_{2}, \\
\text { unknown for }\end{array}$ & $\begin{array}{c}45 \text { mass\% I } \\
(\max )\end{array}$ & $\begin{array}{l}\text { Laboratory scale } \\
\text { testing }\end{array}$ & $\begin{array}{c}\text { Single use leading } \\
\text { to fused silica }\end{array}$ \\
\hline
\end{tabular}




\begin{tabular}{|c|c|c|c|c|c|}
\hline $\begin{array}{c}\text { Material / } \\
\text { Process }\end{array}$ & Process Conditions & $\begin{array}{c}\text { Decontamination } \\
\text { Factor }\end{array}$ & $\begin{array}{l}\text { Capacity of } \\
\text { Adsorbent }\end{array}$ & $\begin{array}{c}\text { Level of } \\
\text { Development }\end{array}$ & Regeneration \\
\hline & Operating Temp $150^{\circ} \mathrm{C}$ & organic iodide & & & waste form \\
\hline Charcoal & $\begin{array}{l}\text { Impregnation with } \\
\text { chemical additives } \\
\text { sometimes useful } \\
\mathrm{NO}_{\mathrm{x}} \text { compounds must } \\
\text { be removed prior to } \\
\text { gas-solid contact }\end{array}$ & $\begin{array}{l}99.998 \% \text { removal } \\
\text { of } \mathrm{I}_{2} \text { in } 5-\mathrm{cm} \\
\text { deep bed }\end{array}$ & $\begin{array}{l}4.0-11.0 \mathrm{mg} \mathrm{I}_{2} / \mathrm{g} \\
\text { Adsorbent }\end{array}$ & $\begin{array}{l}\text { These materials are } \\
\text { not being } \\
\text { considered for } \\
\text { reprocessing } \\
\text { plant use. } \\
\text { Activated carbon } \\
\text { has been used } \\
\text { successfully for } \\
\mathrm{I}_{2} \text { control in } \\
\text { nuclear power } \\
\text { plants. }\end{array}$ & \\
\hline $\begin{array}{l}\text { Caustic } \\
\text { Scrubbing } \\
(1-2 \mathrm{M} \\
\text { aqueous } \\
\text { NaOH } \\
\text { solutions })\end{array}$ & & $\begin{array}{l}50-100 \text { for } \mathrm{I}_{2} \\
\text { Not effective for } \\
\quad \text { organic iodides } \\
\text { Recovers } \mathrm{CO}_{2}\end{array}$ & $\begin{array}{c}1-2 \mathrm{M} \mathrm{NaOH} \\
\text { removes } 90 \text { to } \\
95 \% \text { of } \mathrm{I}_{2}\end{array}$ & $\begin{array}{l}\text { Large-scale facility } \\
\text { use is reported }\end{array}$ & \\
\hline 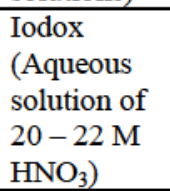 & $\begin{array}{l}\text { Ambient operating } \\
\text { temperature } \\
\text { Handles high } \mathrm{NO}_{\mathbf{x}}\end{array}$ & $\mathrm{Up}$ to $10^{6}$ & & $\begin{array}{l}\text { Demonstration in } \\
\text { cold pilot-plant } \\
\text { conditions }\end{array}$ & $\begin{array}{l}\text { Conversion of } \\
\text { anhydroiodic } \\
\text { acid to barium } \\
\text { iodate needed }\end{array}$ \\
\hline $\begin{array}{l}\text { Mercurex } \\
\text { (Aqueous } \\
\text { solution of } \\
\text { mercuric } \\
\text { nitrate and } \\
\text { nitric acid) } \\
\end{array}$ & $\begin{array}{l}\text { Operating temperature } \\
\text { of } 50^{\circ} \mathrm{C}\end{array}$ & $\begin{array}{c}>10^{5} \text { with } 12-14 \\
\mathrm{M} \text { aqueous } \\
\mathrm{HNO}_{3}\end{array}$ & & $\begin{array}{l}\text { Large-scale } \\
\text { applications are } \\
\text { documented }\end{array}$ & $\begin{array}{c}\text { Removal / recovery } \\
\text { of } \mathrm{Hg} \text { needed? }\end{array}$ \\
\hline $\begin{array}{l}\text { Silver } \\
\text { Reactors } \\
\text { (Ceramic } \\
\text { saddles } \\
\text { glazed with } \\
\text { AgNO }_{3} \text { ) }\end{array}$ & Near $200^{\circ} \mathrm{C}$ & $10-10^{4}$ & & $\begin{array}{l}\text { Large scale } \\
\quad \text { application } \\
\text { reported in US. } \\
\text { No long-term } \\
\text { iodine retention } \\
\text { on surface is } \\
\text { expected }\end{array}$ & $\begin{array}{l}\text { Bed may be } \\
\text { regenerated up } \\
\text { to } 10 \text { times by } \\
\text { removing } \\
\text { accumulated } \\
\text { iodine with a } \\
\text { basic sodium } \\
\text { hyposulfite } \\
\text { solution and } \\
\text { spraying with } \\
\mathrm{AgNO}_{3}\end{array}$ \\
\hline
\end{tabular}

\subsubsection{Iodine Waste Forms}

Iodine waste management can be performed by:

1) discharging to the sea,

2) removing the iodine from the capture media (in this case the AgZ or Ag-aero) and immobilizing either I or AgI separated from the capture media, or

3) using the capture media as a component of the final waste form.

The first option is a technically sound approach which relies on the isotopic dilution of ${ }^{129}$ I by the oceans vast reservoir of ${ }^{127} \mathrm{I}$ (Burger 1980). This practice, employed at LaHague and Sellafield, has resulted in slight ${ }^{129}$ I concentration increases in ocean sediments but well below any potential safety concerns (Lopez-Guitierrez et al. 2004; Alfimov et al. 2004; Kessler 2012). However, the approach is not compliant with current U.S. regulations. The second option generally results in a more complicated process but may result in a higher performing waste form. There are a number of methods to remove 
iodine from the AgIZ for use in waste form fabrication purposes. One example is reducing the silveriodide to silver metal using hydrogen gas at elevated temperature (this would allow for recycling of the silver sorbent).

$$
2 \mathrm{AgI}(\mathrm{s})+\mathrm{H}_{2}(\mathrm{~g}) \rightarrow 2 \mathrm{Ag}(\mathrm{s})+2 \mathrm{HI}(\mathrm{g})
$$

The HI $(\mathrm{g})$ can then be trapped in water or caustic solution (Berger et al. 1981) or trapped on another sorbent more suitable for waste form synthesis. The third option may result in a simpler process and adequate waste form(s). Both the second and third option will be considered here.

Several reviews on ${ }^{129}$ I waste forms have been published (Altomare et al. 1979; Berger et al. 1981; Hebel and Cottone 1982; IAEA 1987; Jubin 1988; Taylor 1990; Perera et al. 2004; Gombert et al. 2008; Nishimura et al. 2009; and Tanabe et al. 2010). These reviews will are briefly summarized below.

\subsubsection{Waste Form Performance Targets}

Iodine-129 is consistently found to be one of the largest dose contributors in geologic repository performance assessments due to its very long half-life $\left(1.6 \times 10^{7} \mathrm{y}\right)$ and high mobility in most geological environments (Swift and Nutt 2011; OECD 2009; Von Lensa et al. 2008). The long half-life has prompted some to suggest iodine management similar to management of stable hazardous metals (e.g., $\mathrm{Pb}, \mathrm{Hg}$, etc.).

Burger (1980) recommended that dilution in both the absolute concentration of ${ }^{129} \mathrm{I}$ and the ratio of ${ }^{129} \mathrm{I}$ : ${ }^{127} \mathrm{I}$ to be the most effective method for managing ${ }^{129} \mathrm{I}$ in a safe and predictable manner. This dilution can be accomplished by: 1) active isotopic dilution of ${ }^{129} \mathrm{I}$ with ${ }^{127} \mathrm{I}$ in the waste form, 2) dispersion of ${ }^{129} \mathrm{I}$ in the sea, or 3) disposal of iodine loaded waste form in a salt repository containing a significant ${ }^{127} \mathrm{I}$ reservoir. Although these are good practical solutions to ${ }^{129}$ I management, the decision of disposal environment will be driven by a number of factors and world experience has shown that safe and predictable disposal options for ${ }^{129} \mathrm{I}$ is achievable by deep geologic disposal without isotopic dilution. It is assumed for the purposes of this study that any generic deep geologic disposal environment may be selected for disposal of the ${ }^{129}$ I containing waste form(s).

A series of calculations were performed to estimate the impact of waste form durability on the performance of generic repositories. These calculations included generic clay/shale, hard rock (e.g., granite), and bedded salt repositories and deep borehole disposal (Vaughn et al. 2012). The general trends show:

- For cases in which the dominant dose contributing radionuclides have half-lives that are much shorter than the expected waste form lifetime, the waste form degradation rate does not have an effect.

- For cases in which the primary barrier to release, the slow diffusive pathway, dominates overall repository performance, the waste form engineered barrier has a negligible effect on repository performance.

- For cases in which the waste form lifetime is on the same order of magnitude as the radionuclide half-life and are not constrained by solubility and diffusion controls, the mean peak annual dose rates are directly proportional to both the mass of the radionuclide disposed and the fractional waste form degradation rate.

An example of this trend is shown for ${ }^{129} \mathrm{I}$ peak annual dose from a clay/shale repository as a function of waste form fractional degradation rate in Figure 2.2. There is a linear relationship between degradation 
rates and peak annual dose for fractional degradation rates below $10^{-6} \mathrm{y}^{-1}$. ${ }^{\mathrm{a}}$ For higher fractional degradation rates, there is not a significant impact. Two conclusions about chemical durability of iodine waste forms are drawn from this phenomenon:

1) ${ }^{129}$ I waste form durability is not important to repository performance if the fractional degradation rate is above $10^{-6} \mathrm{y}^{-1}$.

2) Increasing the chemical durability of the ${ }^{129}$ I-bearing waste form will decrease the peak annual dose linearly for fractional degradation rates below $10^{-6} \mathrm{y}^{-1}$.

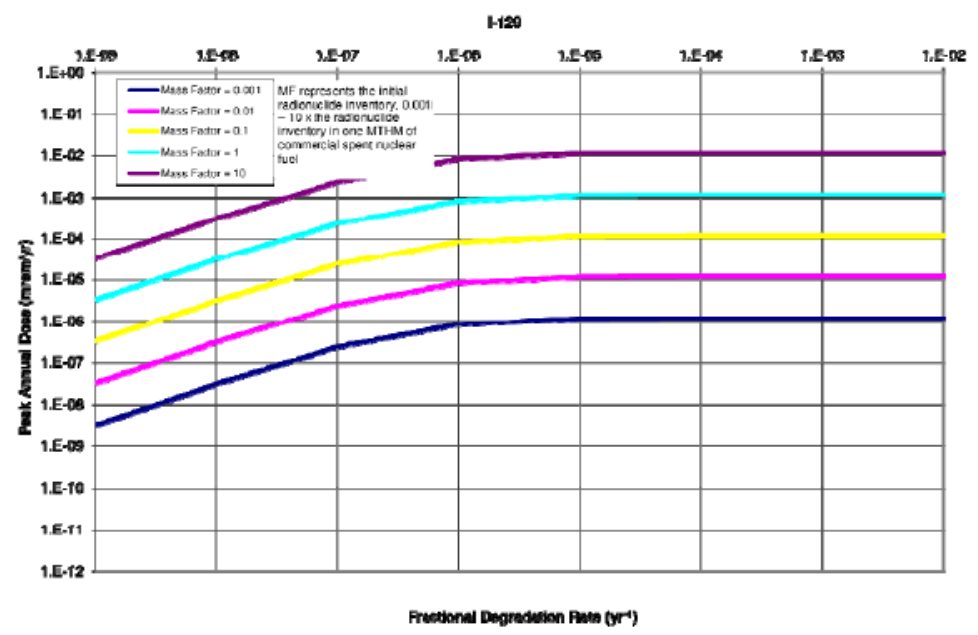

Figure 2.2. Sensitivity of Peak Annual Dose from ${ }^{129}$ I to Waste Form Fractional Degradation Rate (Vaughn et al. 2012)

A target fractional release rate for the iodine waste form is therefore set to be roughly $10^{-7} \mathrm{y}^{-1}$. An engineering study will be required to determine if waste forms with significantly different degradation rates are cost effective when compared to alternative engineering and natural barriers. The fractional degradation rate can be computed from shortest waste form physical dimension (assumed here to be 2.5 inch) and release rate under the given disposal conditions (e.g., $40^{\circ} \mathrm{C}$ ambient temperature, reducing environment, and nearly static solution conditions).

\subsubsection{Waste Forms for Separated Iodine}

Sodalite minerals, apatite glasses, bismuth oxide ceramics, and a range of different low temperature melting glasses have been proposed for immobilization of separated iodine. The majority of the waste form development has been carried out without specific regard to the method of obtaining the iodine initially, and precursor chemicals have generally included iodide or iodate salts such as $\mathrm{AgI}, \mathrm{PbI}_{2}, \mathrm{NaI}$, and $\mathrm{NaIO}_{3}$. Some examples of these waste forms are highlighted below.

\section{Direct Disposal}

Direct disposal of iodide $\left(\mathrm{AgI}, \mathrm{PbI}_{2}, \mathrm{CuI}\right.$, and $\left.\mathrm{HgI}_{2}\right)$ and iodate $\left(\mathrm{Cu}\left[\mathrm{IO}_{3}\right]_{2}, \mathrm{Ca}\left[\mathrm{IO}_{3}\right]_{2}\right.$, and $\left.\mathrm{Ba}\left[\mathrm{IO}_{3}\right]_{2}\right)$ minerals was discussed by Taylor (1990) and Burger et al. (1981). Based on these studies, the most stable of the metal iodides and iodates in most chemical environments (including cement pore water solution) is

a A fractional degradation rate is a convenient way to express the fraction of a radionuclide release from the waste form over a fixed unit of time (e.g., per year). As the waste form degrades, the effective surface area and waste form mass decrease and thus the fractional degradation rate decreases. This reduction in degradation rate is well approximated by an exponential decay with the unit of inverse years; hence the waste form "half-live" is often used as an approximation. 
AgI. Inagaki et al. studied the dissolution rate of $\mathrm{AgI}$ in reducing environments with the presence of $\mathrm{FeCl}_{2}$ (Inagaki et al. 2008) in dilute flowthrough conditions. Under these conditions, dissolution of AgI is controlled by a redox reaction with $\mathrm{Fe}^{2+}$ which is kinetically retarded by the formation of $\mathrm{Ag}^{0}$ passivation layer over the AgI particles. AgI is relatively soluble in acetate solution which is the solution used for testing by the U.S. Environmental Protection Agency (EPA) Toxicity Characteristic Leaching Procedure (TCLP) (EPA 1992). The solubility of silver acetate is $0.062 \mathrm{M}$ or $6.7 \mathrm{~g} \mathrm{Ag} / \mathrm{L}$ (Dean 1973). AgI therefore does not pass the EPA standards for land-disposal (as was confirmed for AgIZ with a resulting Ag concentration of $125 \mathrm{mg} / \mathrm{L}$ per Scheele et al. (2002)) and would require further treatment for disposal in a non-RCRA licensed facility. None of these minerals have demonstrated performance in the right order of magnitude to significantly influence peak annual dose from deep geologic disposal facilities.

\section{$\underline{\text { Sodalite }}$}

Iodide sodalite is an aluminosilicate material (ideally, $\mathrm{Na}_{8} \mathrm{Al}_{6} \mathrm{Si}_{6} \mathrm{O}_{24} \mathrm{I}_{2}$ ) that requires high pressure and temperature to be produced. Synthesis with up to 11.7 mass\% equivalent I has been demonstrated, with a theoretical waste loading of 22.0 mass\% (Babad and Strachan 1980; IAEA 1987, Sheppard et al. 2006). Hirabayash et al. (2012) developed a low-temperature method of forming sodalite from radioiodine contianing $\mathrm{AgX}$ in an autoclave at $150^{\circ} \mathrm{C}$. The solubility of the iodide sodalite was approximately $2 \times 10^{-}$ ${ }^{4} \mathrm{~mol} / \mathrm{L}$ with a normalized release rate of $10^{-4}$ to $10^{-5} \mathrm{~g} \cdot \mathrm{m}^{-2} \cdot \mathrm{d}^{-1}$ at disposal temperature (Nakazawa et al. 2001). Maddrell et al. 2014 measured the durability of iodide sodalite using MCC-1 test with an S/V of 1 $\mathrm{cm}^{-1}$, a temperature of $90^{\circ} \mathrm{C}$, and a $\mathrm{pH}$ buffered at 11 . The resulting normalized iodine release rates ranged from $0.005-0.01 \mathrm{~g} \cdot \mathrm{m}^{-2} \cdot \mathrm{d}^{-1}$. These rates are quite high, but, they have been measured under relatively extreme conditions. Taylor (1990) recommended iodide sodalite as the most appropriate iodine waste form for durability controlled release materials.

\section{Glasses}

Iodine incorporation into glass has been investigated in many different systems, for applications ranging from optical materials to batteries to nuclear waste immobilization. These studies used either iodine or iodine compounds. The primary oxide glass systems that have been studied for glass formation with iodine or iodine-containing compounds are borates (Dalba et al. 1990; Mustarelli et al. 2005; Rocca et al. 1992; Rousselot et al. 1995; Souto et al. 1994), borosilicates (Maddrell and Abraitis 2004), and tellurites (Chowdari et al. 2000). Many glass systems with oxyanions which alone form low melting point alkali salts form glass well with AgI, including molybdates (Chowdari et al. 1998; Mustarelli et al. 2005; Rousselot et al. 1995; Sanson et al. 2007a; Sanson et al. 2007b), tungstates (Mustarelli et al. 2005; Senapati and Austen Angell 1991), arsenate (Rousselot et al. 1995), and phosphates (Mustarelli et al. 2005; Rousselot et al. 1995; Sakuragi et al. 2008; Yang et al. 2014). Finally, a large portion of literature on iodine-containing glasses has focused on non-oxide, chalcogen ( $\mathrm{Ch} ; \mathrm{S}, \mathrm{Se}$, and/or Te)-containing compounds, including As-, Ge-, P-, and Zn-sulfides, selenides and/or tellurides, or other mixed-cation halides, e.g., $\mathrm{Ag}, \mathrm{K}, \mathrm{Pb}$. When put into glass, iodine is thought to enter the glass network in place of other ions like oxygen, but in some cases, the iodine appears to occupy interstitial sites in the glass network (Choi and Shin 1996).

In typical borosilicate waste glasses, solubility of iodine was initially thought to be very low but this can be attributed to low retention of iodine during the melting process (Hrma 2010), posing processing limitations for making glasses with high iodine content. Thus, low-temperature processing glasses are more common in the literature. One of the more commonly studied glass systems in the literature for incorporating $\mathrm{AgI}$ are of the family $\mathrm{AgI}-\mathrm{Ag}_{2} \mathrm{O}-\mathrm{X}$, where $\mathrm{X}$ is often a mixture of $\mathrm{P}_{2} \mathrm{O}_{5}, \mathrm{~B}_{2} \mathrm{O}_{3}, \mathrm{Bi}_{2} \mathrm{O}_{3}$, and $/$ or other additives. Mukunoki et al. (Mukunoki et al. 2007; Mukunoki et al. 2009) have developed a process for capturing I- in $\mathrm{BiPbO}_{2} \mathrm{I}$ and mixing with a low-melting $\mathrm{PbO}-\mathrm{B}_{2} \mathrm{O}_{3}-\mathrm{ZnO}$ glass for immobilizing iodine 
using a low-temperature process of $\sim 520^{\circ} \mathrm{C}$. A system of $(\mathrm{AgI})_{1-\mathrm{x}}\left(\mathrm{Ag}_{2} \mathrm{MoO}_{4}\right)_{\mathrm{x}}$ glasses where $0.2<\mathrm{x} \leq 0.4$ has been studied as well with high AgI fractions (Rocca et al. 1999).

Phosphate glass systems have particularly been investigated for nuclear waste immobilization of iodine (Sakuragi et al. 2008; Yang et al. 2014).

Due to their more covalent nature, non-oxide glasses such as chalcogenide glasses, can accommodate more iodine in their network, and thus silver sulfides containing P or As have been studied as cation conductors (Rousselot et al. 1995; Sanghera et al. 1988). Traditional chalcogenide glasses without silver have also been studied containing large fractions of iodine (Koudelka and Pisárcik 1984), particularly because iodine additions result in novel optical properties. Extremely high fractions of iodine, up to 33 $\mathrm{mol} \%$, have been reported in chalcogenide glasses, such as (As,Sb)-(S,Se,Te)-I and (Si,Ge)-(S,Se,Te)-I (Sanghera et al. 1988). In general, chalcogenide glasses have lower glass transition temperatures of 200$400^{\circ} \mathrm{C}$ versus $>500^{\circ} \mathrm{C}$ for typical silicate-based HLW glasses. Chalcohalide glass systems containing $\mathrm{PbI}_{2}$ (Lima et al. 2001; Troles et al. 2003) and CuI (Salmon and Xin 2002) have also been reported. Infrared-transmitting glass ceramics in the Ge-Ga-(S,Se)-alkali iodide (Lin et al. 2013; Tang et al. 2008; Yang et al. 2007) and lead iodide (Guo et al. 2007a; Guo et al. 2007b) systems are an area of current research for optical applications. The affinity of chalcogenide systems for iodine is the principal reason for considering them as sorbents using chalcogen-based aerogels called chalcogels.

\section{Apatite}

Apatite materials, primarily $\mathrm{Pb}_{5}\left(\mathrm{VO}_{4}\right)_{3} \mathrm{I}$, have been developed for the immobilization of radioiodine (Audubert 1997; Guy et al. 2002; Perera et al. 2003; Zhang et al. 2007; Le Gallet et al. 2010; Stennett et al. 2011). This material becomes unstable in air at temperatures above the typical sintering point of $700^{\circ} \mathrm{C}$. Therefore, layered composites (Audubert et al. 1997 and Guy et al. 2002), hot isostatic press (HIP) synthesis (Perera et al. 2003 and Zhang et al. 2007), fast microwave heating (Stennett et al. 2011), or spark plasma sintering (SPS) at low temperature (Campayo et al. 2009; Le Gallet et al. 2010) were used to contain the iodine during processing. The final waste form is suspected to release iodine via an interdiffusion or ion exchange process (Guy et al. 2002; Zhang et al. 2007; Maddrell and Abraitis 2004). Guy et al. 2002 found the initial dissolution rates vary with $\mathrm{pH}$, time, and temperature. A typical Vshaped dependence of $\log$ rate on $\mathrm{pH}$ is seen with a relatively steep slope in lower $\mathrm{pH}$ 's, a minimum near $\mathrm{pH} 8$, and a shallower slope at higher $\mathrm{pH}$ 's. The rate varies with time from an initial rate near $0.2 \mathrm{~g} \cdot \mathrm{m}^{-2} \cdot \mathrm{d}$ ${ }^{1}$ to roughly $5 \times 10^{-4} \mathrm{~g} \cdot \mathrm{m}^{-2} \cdot \mathrm{d}^{-1}$ at 400 days. An activation energy for dissolution initial dissolution rate is 37 $\mathrm{kJ} \cdot \mathrm{mol}^{-1}$.

More recently, attempts have been made to produce iodine containing oxyapatites (Campayo et al. 2011; Coulon et al. 2014). The material is fabricated by a cement-like reaction of a mixture of one mole tetracalcium phosphate, two moles tricalcium phosphate, and half a mole of sodium iodate in water. The resulting material is a porous monolithic (cement-like) solid containing primarily $\mathrm{Ca}_{10}\left(\mathrm{PO}_{4}\right)_{6}(\mathrm{OH})_{1.6}\left(\mathrm{IO}_{3}\right)_{0.4}$ with roughly 6.5 mass\% iodine. Normalized iodine losses during a $90^{\circ} \mathrm{C} \mathrm{MCC}$ 1 test (with $460 \mathrm{~cm}-1 \mathrm{~S} / \mathrm{V}$ ) were measured in DIW at $10^{-4} \mathrm{~g} \cdot \mathrm{m}^{-2} \cdot \mathrm{d}^{-1}$ (measured after two days).

\section{Layered Bismuth Oxy-iodides}

Krumhansl and colleagues have developed a hydrotalcite-like layered bismuth oxide waste form for radioiodine (Krumhansl et al. 2009; Krumhansl and Nenoff 2011; Krumhansl and Nenoff 2013). A series of materials with $\mathrm{Bi}: \mathrm{O}: \mathrm{I}$ ratios ranging from $\mathrm{BiOI}$ to $\mathrm{Bi}_{5} \mathrm{O}_{7} \mathrm{I}$ were fabricated by an aqueous precipitation process. The chemical durabilities of the materials were characterized using a 7-day static test in DIW at temperatures ranging from 20 to $90^{\circ} \mathrm{C}$. The samples with Bi:I ratios in the range of 1.67 to 2.12 performed significantly better in static leach tests compared to samples with either higher or lower Bi:I 
ratios ( $<4 \mathrm{mg} \mathrm{I} / \mathrm{L}$ ), suggesting an ideal formulation of $2 \mathrm{Bi}$ for every $\mathrm{I}$. The authors suggest that the iodine release under these conditions may be solubility controlled.

\section{$\underline{\text { Cement }}$}

Concrete has the advantages of low cost and known technology. It has been reported that the lowest leach rate would result in complete leaching in about $2 \times 10^{4} \mathrm{y}$ (IAEA 1987). This is too short of time to meet the stated performance criteria. However, it may be used to increase performance under certain conditions such as interim storage, transportation, and repository intruder conditions. Concrete has been used to provide additional protection and physical strength to $\mathrm{Ba}\left(\mathrm{IO}_{3}\right)_{2}$; a USSR fuel recycle plant of 1500 $\mathrm{t} / \mathrm{yr}$ was shown to generate about $9 \mathrm{~m}^{3}$ of concrete containing barium iodate with a leach rate of 2-6 $\times 10^{-6}$ $\mathrm{g} \cdot \mathrm{cm}^{-2} \cdot \mathrm{d}^{-1}$ (IAEA 1987). Recent Japanese studies have evaluated the use of cement to immobilize AgA and AgS (Toyohara et al. 2002; JAEA and FEPC 2007; Haruguchi et al. 2012).

Simple iodine compounds, such as AgI, were studied in cements as an immobilization form. It was found that $\mathrm{AgI}$ became unstable in slag cement due to the reduction of $\mathrm{Ag}^{+}$to $\mathrm{Ag}^{0}$ leading to release of $\mathrm{I}$. It was proposed that $\mathrm{AgNO}_{3}$ should be included in cement so as the iodine became soluble the $\mathrm{Ag}$ would also become soluble and be available for scavenging radioiodine (Atkins et al 1990). However, in the short term, $\mathrm{AgNO}_{3}$ showed very low solubilities (Atkins et al. 1990). High calcium silicate hydrogels and calcium aluminate sulphate hydrates (such as $\mathrm{Ca}_{4} \mathrm{Al}_{2} \mathrm{SO}_{4}(\mathrm{OH})_{6} \cdot 6 \mathrm{H}_{2} \mathrm{O}$ ) could maximize the immobilization of I. This can be done with a 30 to $40 \%$ slag blend with aging (Atkins and Glasser 1990).

Clark and colleagues (Clark 1977; Clark and Thompson 1977) describes incorporation of barium iodate in Portland cement for use in a liquid metal breeder reactor fuel reprocessing waste loaded to between 3 and 12 mass\% I. Burger et al. (1981) report the relative corrosion rates of $\mathrm{AgI}$ and $\mathrm{Ba}\left(\mathrm{IO}_{3}\right)_{2}$ in cement.

\subsubsection{Waste Forms for Iodine on Solid Capture Media}

\section{Cement Encapsulation}

Encapsulation of AgIZ in cement was proposed by Burger et al. (1981). They found that the AgIZcontaining cement was more than an order of magnitude more durable than an equivalently iodine loaded cement containing $\mathrm{Ba}\left[\mathrm{IO}_{3}\right]_{2}$ in dynamic leach tests; while the rates were roughly equivalent for static tests. Scheele et al. (2002) compared the TCLP responses of AgIZ (125 mg Ag/L) with grouted AgIZ $(<0.006 \mathrm{mg} \mathrm{Ag} / \mathrm{L})$. These were based on a type III cement mixture fabricated with 24 mass $\% \mathrm{H}_{2} \mathrm{O}: 51$ cement:25 AgIZ. The addition of ${ }^{127} \mathrm{I}$ (in the form of $\mathrm{CaI}_{2}$ ) as a $3: 1$ isotopic diluent was also proposed. A final cement formulation of 21 mass $\% \mathrm{H}_{2} \mathrm{O}: 42$ cement:26 AgIZ:11 CaI $\mathrm{C}_{2}$ was proposed as the final waste form. Trevorrow et al. (1983) estimate the lifetime of cemented AgIZ to be on the order of $10^{4}$ years (assuming monolithic cement in standard 55-gallon drums).

\section{Glass Encapsulation}

Nenoff and colleagues have developed a glass composite material (GCM) for the immobilization of radioiodine loaded AgZ (AgIZ) (Nenoff et al. 2008, 2011, 2012, 2014b,c,d; Garino et al. 2011). To fabricate this waste form, the AgIZ media is ground and mixed with a powdered bismuth-zinc-silicate glass frit and sintered at $550^{\circ} \mathrm{C}$. The waste loading is generally 25 mass $\%$ AgIZ. When the commercially available $\mathrm{AgZ}$ is used, then this translates to 1-2 mass\% iodine. This loading may be increased if optimal $\mathrm{AgZ}$ material (e.g., the synthetic AgZ with 18 mass\% Ag previously available from Norton) is used. The chemical durability of this product has been measured using single-pass flow-through methods under dilute conditions (Nenoff et al. 2012). Iodine is released from GCM at less than $10^{-16} \mathrm{~mol} \cdot \mathrm{cm}^{-2} \cdot \mathrm{s}^{-1}$ at 25 ${ }^{\circ} \mathrm{C}$ and $\mathrm{pH}=3$ and $\mathrm{pH}=8$. In the measured conditions, Bi-Si-Glass dissolves at rates similar to, and 
possibly lower than, traditional nuclear waste glasses. Temperature has a relatively small effect on both glass degradation and Ag and I release; maximum glass dissolution activation energies are $30 \mathrm{~kJ} / \mathrm{mol}$. The rate model for iodine release from GCM waste form is estimated at: Rate $\left(\mathrm{mol} \cdot \mathrm{cm}^{-2} \cdot \mathrm{s}^{-1}\right)=3.6 \times 10^{-}$

${ }^{12} \exp (-3608 / \mathrm{T})$. Detailed information on this waste form and the process technology are given in Section 2.2.2.5.

This specific glass frit has also been tested as a potential waste form for other was streams (Nenoff et al. 2012). Similar sintering glasses for waste encapsulation using other frit compositions have been tested and used in many applications (Gahlert and Ondracek 1988a,b; Vienna et al. 1999; Bernardo et al. 2006; Michie et al. 2008; Malek et al. 2009; and Mayzan et al. 2014).

\section{Heat Treated Silica Aerogels}

In recent years, silica aerogels have been studied for confinement of radioactive wastes due to their low cost, commercial availability, and high specific surface areas upwards of $1200 \mathrm{~m}^{2} / \mathrm{g}$ (Woignier et al. 1998, 2000; Reynes et al. 2001). As with AgZ, aerogels can act as precursors to the final glass matrix in which the waste is actually immobilized (Woignier et al. 2000). The porous network of silica aerogel has been used as a host matrix, or a sponge, for nuclear wastes (Reynes et al. 2001), where the silica aerogel was soaked in a solution containing actinides in nitrate salt form and, after drying and nitrate decomposition, the composite material is fully sintered, trapping the nuclear waste.

Matyas and colleagues are currently developing Ag-functionalized silica aerogels as iodine sorbents (Matyas et al. 2011,2012a,b, 2013; Strachan et al. 2011b). This particular sorbent is comparable to AgZ in that both have a porous oxide scaffold with $\mathrm{Ag}^{0}$ binding sites for iodine, but with the significant advantage that it can be directly consolidated to form a fused silica-based waste form with encapsulated AgI nano-particles. The durability of the waste form is expected to be controlled by the dissolution of the silica to exposing the AgI particles, and by the solubility of AgI. Fused silica durability has been studied by many researchers and is significantly higher than that of typical borosilicate waste glasses. Fresh AgAero has a capacity of roughly 45 mass $\% \mathrm{I}_{2}$. However, aging in process may reduce the capacity to as low as 22 mass\%. Denisfication by HUP at temperatures as low as $1050^{\circ} \mathrm{C}$ was demonstrated with iodine retention of $>92 \%$ and densities as high as $2.2 \times 10^{3} \mathrm{~kg} / \mathrm{m}^{3}$. Detailed information on this waste form and the process technology are given in Section 2.2.2.6.

\section{$\underline{\text { Hot Pressed Silver Sorbents }}$}

Direct conversion of solid iodine capture media into waste forms by hot-pressing, in particular by HIP, has been proposed by a number of researchers. Miyakawa et al. (2013) have developed an alumina based "Synroc" waste form by HIPing I-loaded AgA. The loaded AgA material heated under vacuum to convert $\mathrm{AgNO}_{3}$ and $\mathrm{AgIO}_{3}$ to $\mathrm{AgI}$ and the material is $\mathrm{HIPed}$ at $1200^{\circ} \mathrm{C}$ under $175 \mathrm{MPa}$ for $3 \mathrm{~h}$ (Tanabe et al. 2010). AgI particles are encapsulated in the dense $\mathrm{Al}_{2} \mathrm{O}_{3}$ grain boundaries and triple points (JAEA 2007; Tanabe et al. 2010). The bulk density of the materials is $4,050 \mathrm{~kg} / \mathrm{m}^{3}$ with roughly $8 \%$ porosity (1$3 \%$ open porosity). The release of iodine is suggested to be controlled by bulk corrosion of the $\mathrm{Al}_{2} \mathrm{O}_{3}$ phase which, in-turn, is controlled by the solubility of amorphous $\mathrm{Al}(\mathrm{OH})_{3}$ (Miyakawa et al. 2013; Tanabe et al. 2010).

Fujihara et al. (1999) HIPed AgI-containing porous silica sorbents at $1500^{\circ} \mathrm{C}$ for $3 \mathrm{~h}$ at $100 \mathrm{MPa}$ to form a synthetic rock waste form. The resulting waste form was primarily crystalline quartz with AgI found in the grain boundaries and triple points (JAEA 2007). The low solubility of quartz in disposal environment solutions suggested high iodine retention in the final waste form. Testing in dynamic solution showed that for the first roughly 50 days (at $35^{\circ} \mathrm{C}$ ) the iodine release was a function of the square root of time. After 50 days, little to no release was measured out to 300 days (JAEA 2007). 
Direct conversion of silver zeolites into a final waste form by HIPing has been developed by a number of researchers. HIPing of AgX to form sodalite was described above (Sheppard et al. 2006; Sheppard 2009; Maddrell 2014). Direct hot-pressing of AgIZ has been attempted (Jubin et al. 2014b; Jubin and Bruffey 2014). Both crushed and uncrushed AgIZ were HIPed and no obvious advantage to crushing was found. Densities in the range of 2500 to $2650 \mathrm{~kg} / \mathrm{m}^{3}$ were achieved. Under the conditions used in these tests, the majority of the resulting materials were fully amorphous. Although the results of these tests are preliminary, the approach does seem promising.

\subsubsection{Summary of Iodine Waste Forms and Recommendations}

Based on the selection of $\mathrm{AgZ}$ as the reference capture media and AgAero as the primary alternative option for iodine capture, the GCM and collapsed silica aerogel waste forms are the most appropriate baseline waste forms for iodine in this study. Both of these waste forms have a high potential to have waste form stability half-lives in the disposal facility on the same order of magnitude as the half-life of

${ }^{129} \mathrm{I}$. Both of these have a process demonstrated to fabricate a dense and durable waste form. Direct hot pressing of AgIZ should also be considered as a high potential value alternative to the GCM for AgIZ immobilization.

The GNEP waste management baseline recommended grouted AgIZ as the preferred waste form for iodine (Gombert et al. 2007). That was not selected in this study due to the relatively poor performance, waste loadings, and impacts of cement leach solutions on the performance of other materials in the disposal facility.

\subsubsection{Glass Composite Material Fabrication}

Section 2.2.1 describes the selection of $\mathrm{AgZ}$ as the reference iodine capture media in the DOG, VOG, HOG, and MOG treatment systems. In addition, $\mathrm{AgZ}$ will be used in the off-gas treatment for the iodine sorbent waste form fabrication process.

In the reference case, the iodine loaded $\mathrm{AgZ}$ is immobilized in a low-temperature glass composite material (GCM) (Nenoff et al. 2008, 2011, 2014b,c,d; Garino et al. 2011). The AgZ columns are operated with two banks in series and are alternatively used as the lead and lag bank. The lead bank is replaced when breakthrough occurs, the $\Delta \mathrm{P}$ meets the predetermined limit, or the scheduled life is achieved. The lag bank then becomes the lead bank and the newly replaced media becomes the lag bank. Any physisorbed halogens and tritium is removed from the $\mathrm{AgZ}$ by heating (to between 150 and $225^{\circ} \mathrm{C}$ ) under flowing nitrogen. The resulting gas is passed through the remaining bank. After degasing is complete, the iodine-loaded AgZ (AgIZ) media is removed from the absorber cartridge, ground, mixed with glass frit, cold-pressed, and sintered into a final GCM waste form.

The AgIZ is ground to a particle size of $<150 \mu \mathrm{m}$ (equivalent screen aperture) and mixed in a 24.7 AgIZ:74.2 frit:1.1 mass\% Ag metal flake ratio. The frit is assumed to be Ferro Corp. (Cleveland, $\mathrm{OH}$ ) number EG2922 glass powder. This is a commercially available Bi-Si-oxide glass ( $3 \mu \mathrm{m}$ average particle size, a density of $5.8 \mathrm{~g} / \mathrm{cm}^{3}$, coefficient of thermal expansion of $7.8 \times 10^{-6} /{ }^{\circ} \mathrm{C}$, from). The glass has a composition of: 7.8 mass $\% \mathrm{ZnO}, 63.4$ mass $\% \mathrm{Bi}_{2} \mathrm{O}_{3}, 5.4$ mass $\% \mathrm{Al}_{2} \mathrm{O}_{3}, 23.4$ mass $\% \mathrm{SiO}_{2}$. An organic binder of polyvinylalcohol and polyethyleneglycol is included in the mixture to add strength to the pressed green material. The mixture is uniaxially pressed into $0.179-\mathrm{m}$ diameter cylinders at roughly 70 $\mathrm{MPa}$. Each green cylinder is sintered at between 500 and $550^{\circ} \mathrm{C}$ and $30 \mathrm{MPa}$ for $1 \mathrm{~h}$. The sintered cylinders have target dimensions of $\sim 85 \%$ of the die (due to shrinkage) whose dimensions are $0.152-\mathrm{m}$ (6 inch) diameter by $63-\mathrm{mm}(2.5 \mathrm{inch})$ tall and have a density of $\sim 4.0-4.15 \times 10^{3} \mathrm{~kg} / \mathrm{m}^{3}$ (as determined by 
iodine loading levels). ${ }^{\mathrm{b}}$ Twenty sintered GCM waste forms are loaded into a $0.155-\mathrm{m}$ diameter $\times 1.34-\mathrm{m}$ (4.4 foot) tall canister. The canister is welded closed and decontaminated if necessary.

The empty off-gas cleaning cartridges are cleaned in dilute $\mathrm{HNO}_{3}$ solution then rinsed in water. The cleaned cartridges are either reloaded with $\mathrm{AgZ}$ and reused or disposed of as LLW. The air stream for the glovebox line where the grinding, mixing, and cold pressing are performed is filtered for particulate with a pulseable filter and the particulate mixed back into the next batch of GCM waste form fabrication. Gases from the glove box (after the pulsed filter) and the sintering furnace passes through a HEPA filter and an AgZ column. This process is shown schematically in Figure 2.3.

To estimate the masses and volumes of iodine-bearing GCM produced, all of the halogens being captured by the media need to be considered. Bromine is the only other halogen found in fuel meat in significant quantities. The mole ratio of $\mathrm{Br}$ to I in fuel is relatively constant with burnup in LWRs at 0.162 .

Impurities in the cold process chemicals can significantly increase halogen content. For example, $\mathrm{Cl}$ and $\mathrm{F}$ are common impurities in nitric acid with concentrations ranging from $0.08 \mathrm{ppm} \mathrm{Cl}$ and $1 \mathrm{ppm} \mathrm{F}$ for reagent grade to $100 \mathrm{ppm} \mathrm{Cl}$ in bulk $\mathrm{HNO}_{3}$ supplies ( $\mathrm{F}$ not reported in bulk $\mathrm{HNO}_{3}$ specifications).

Chlorine concentrations of up to $200 \mathrm{ppm}$ are commonly found in bulk $\mathrm{NaOH}$.

Nitric acid consumption within a processing plant is a function of a number of factors, but the largest is the ability to capture and recycle the acid within the plant. Estimates of the nitric acid requirements vary widely. Using the design of a small experimental reprocessing facility from the early $1980 \mathrm{~s}$, the acid consumption for processed fuel was projected to be $68 \mathrm{~kg} / \mathrm{t}$. Starting with the specification from tanker quantities of $\mathrm{HNO}_{3}$ with $100 \mathrm{ppm} \mathrm{Cl}$, this would result in a $\mathrm{Cl}$ loading of $6.8 \mathrm{~g} / \mathrm{tU}$. In the case of the Spent Fuel Treatment Facility, the acid consumption was estimated at $800 \mathrm{~kg} / \mathrm{tU}$ and for the Advanced Fuel Cycle Facility, the acid use was $3800 \mathrm{~kg} / \mathrm{tU}$. A simple average value is $1560 \mathrm{~kg} / \mathrm{tU}$ would result in $\mathrm{Cl}$ releases of $\sim 160 \mathrm{~g} / \mathrm{tU}$ of fuel processed. This is of the same order of magnitude as the $\mathrm{I}_{2}$ in the fuel. In fact for the low burn-up case, the ratio of $\mathrm{Cl}$ to $\mathrm{I}$ is greater than $3: 1$. For the high burn-up case this ratio is 1.6:1. This potentially increases the mass of the iodine waste form by a factor of 2.5 to 4 .

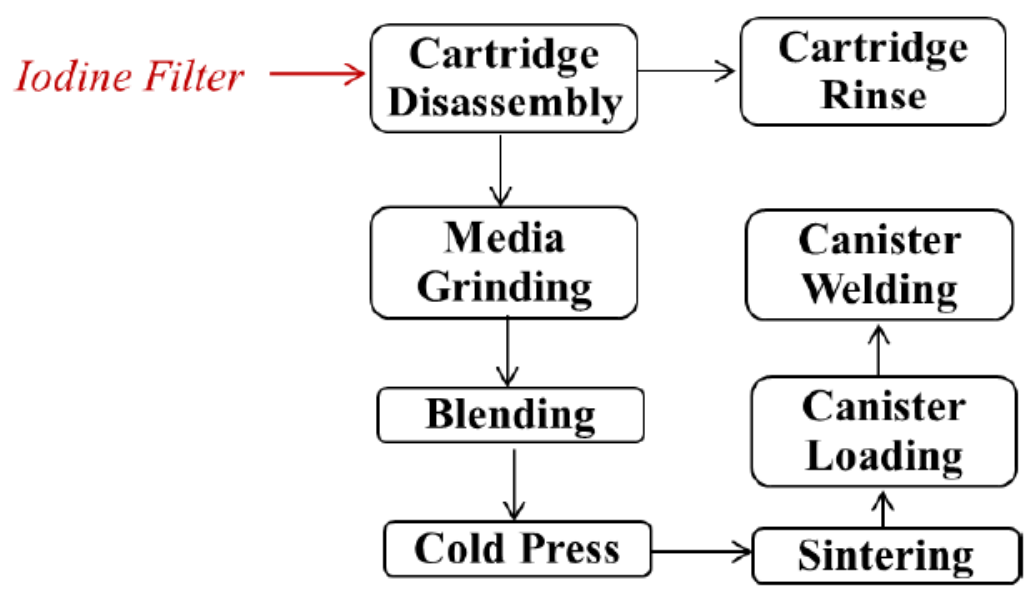

Figure 2.3. AgIZ Treatment Box Flow Diagram for the Reference Flowsheet

b These dimensions are both reasonably attainable by the process described and are consistent with all proposed disposal options including deep boreholes. 
Fresh $\mathrm{AgZ}$ has a capacity of 7 to 9 mass $\% \mathrm{I}_{2}$. However, aging in process reduces that loading by 40 to $60 \%$ (depending on water content and aging time) (Jubin et al. 2012c). After aging, the $\mathrm{I}_{2}$ capacity is roughly 4 mass\%. It is assumed that other halogens replace I on an equal molar basis and account for a fraction of the 4 mass\% limit. For the reference fuel (Table 1.1), the I inventory is $357 \mathrm{~g} / \mathrm{tU}$. Assuming $160 \mathrm{~g} / \mathrm{tU}$ total $\mathrm{Cl}(4.51 \mathrm{~mol} / \mathrm{tU})$ and $0.162 \mathrm{~mol} \mathrm{Br} / \mathrm{mol} \mathrm{I}$ in fuel, there would be $7.78 \mathrm{~mol} / \mathrm{tU}$ total halogen or an equivalent $\mathrm{I}_{2}$ mass of $988 \mathrm{~g} / \mathrm{tU}$. At 4 mass\% loading, there would be $24.7 \mathrm{~kg} / \mathrm{tU}$ AgIZ and at a nominal loading of 19 mass $\%$ AgIZ in GCM there would be $130 \mathrm{~kg} / \mathrm{tU}$ GCM. This will generate 0.030 $\mathrm{m}^{3} / \mathrm{tU}$ GCM waste form or 1.06 canisters of GCM per tU processed.

\subsubsection{Silica Aerogel Waste Form Fabrication}

A promising alternative iodine capture media is the silver-functionalized silica aerogel (AgAero). In the advanced flowsheet, AgAeros are used in the cartridge filters (Matyas et al. 2011, 2012a,b, 2013, 2014; Strachan et al. 2011b). The iodine-loaded AgAero cartridges are handled in a similar fashion to the AgIZ cartridges described above. However, due to the nature of the iodine-loaded AgAero, the final waste form is a directly sintered $\mathrm{SiO}_{2}$ glass encapsulating the iodine-loaded AgAero. This difference allows for a single step treatment that includes the disassembly of the cartridges, hot uniaxial pressing (HUPing) of the granular iodine-loaded AgAero to form cylinders that are sized to fit a disposal canister. The HUP is operated at $1200{ }^{\circ} \mathrm{C}$ and $30 \mathrm{MPa}$ for $1 \mathrm{~h}$ producing a $0.152-\mathrm{m}(6 \mathrm{inch})$ diameter $\times 63-\mathrm{mm}(2.5 \mathrm{inch})$ tall cylinder with a density of $3 \times 10^{3} \mathrm{~kg} / \mathrm{m}^{3}$. . Twenty sintered cylinders are loaded into a $0.155-\mathrm{m}$ diameter $\times$ $1.34 \mathrm{~m}$ (4.4 foot) tall canisters. The canisters are welded closed and decontaminated, if necessary. The rest of the process is the same as the reference flowsheet and is shown schematically in Figure 2.4.

Fresh AgAero has a capacity of roughly 45 mass $\% \mathrm{I}_{2}$. However, aging in process could reduce that loading. After aging, the $\mathrm{I}_{2}$ capacity ranges between 22 and 32 mass\% (Bruffey et al. 2012, 2013). It is assumed that other halogens replace I on an equal molar basis and account for a fraction of the nominal 27 mass\% average aged AgAero loading. For the reference fuel (Table 1.1) there is a total halogen equivalent $\mathrm{I}_{2}$ mass of $988 \mathrm{~g} / \mathrm{tU}$. At 27 mass\% loading, there would be $3660 \mathrm{~g} / \mathrm{tU} \mathrm{SiO}_{2}$ waste form. This generates $1.22 \times 10^{-3} \mathrm{~m}^{3} / \mathrm{tU} \mathrm{SiO} \mathrm{Si}_{2}$ waste form or 0.053 canisters of per tU processed or about 20 times less than the reference GCM.

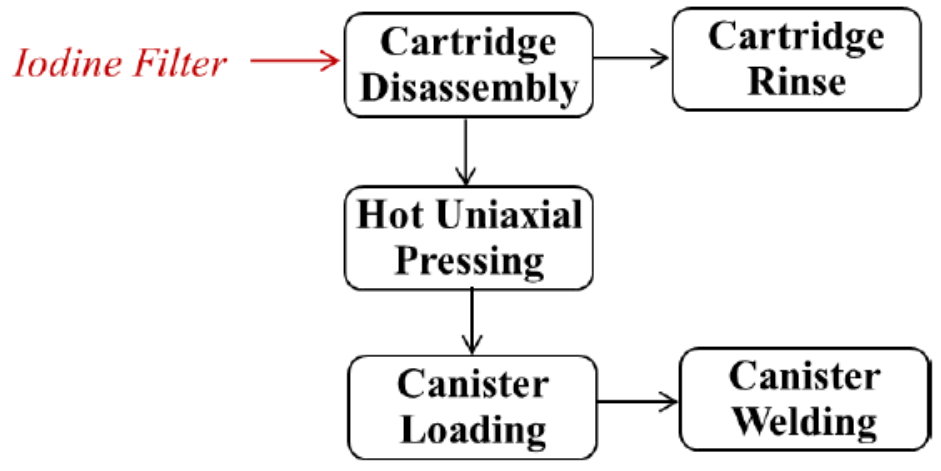

Figure 2.4. AgAero Treatment Box Flow Diagram for the Advanced Flowsheet

c These dimensions are both reasonably attainable by the process described and are consistent with all proposed disposal options including deep boreholes. 


\subsection{Krypton}

Most of the ${ }^{85} \mathrm{Kr}(>99 \%)$ remains in the spent fuel until it is sheared and dissolved. About 1 to $3 \%$ of the fission gases are released during fuel pin sheering, depending on fuel characteristics. This means that most of the ${ }^{85} \mathrm{Kr}$ would be primarily released in the DOG with a concentration in the range of hundreds of parts per million. Recovery processes are based on physical separation from the off-gas since $\mathrm{Kr}$ is chemically inert. The primary technologies for ${ }^{85} \mathrm{Kr}$ control are cryogenic distillation, fluorocarbon adsorption, and sorption on molecular sieves or charcoal. Xenon is, by the time most fuel is processed, a chemically stable fission product (the longest half-life is $36.4 \mathrm{~d}$ ) and is also removed from the off-gas streams in these processes. Xenon is present at about 10 times the $\mathrm{Kr}$ concentration.

\subsubsection{Kr Recovery Processes}

\subsubsection{Cryogenic Distillation}

Cryogenic distillation is a technology to recover rare gases that has been used commercially for many years (Baetsle and Broothaerts 1977; Chesne et al. 1977; Henrich and von Ammon 1985b; Laser et al. 1973a; Yarbro et al. 1977). The cryogenic distillation process has been successfully used at the Idaho Chemical Processing Plant (ICPP) to recover Kr (Soelberg et al. 2013). This commercial technology was not optimized for removal of $\mathrm{Kr}$ at high DFs. Further development work has been done in Belgium, France, Germany, India, and Japan on the cryogenic process (Barnert-Wiemer and Merz 1977; Bendixsen and German 1971; Bendixsen et al. 1973; Bendixsen and Knecht 1976; Bendixsen et al. 1971; Bohnenstingl et al. 1976; Casa 1977; Collard et al. 1981a; Davis and Martin 1973; Geens et al. 1981; Geens et al. 1985; Geens et al. 1986; Henrich and Von Ammon 1985a; Hutter et al. 1987; Inada et al. 1979; Keilholtz 1971; Khan et al. 1975; Laser 1976; Laser et al. 1973b; Martin 1977; Monson 1982; Offutt and Bendixsen 1969; Pence and Chou 1981; Ringel et al. 1981; Tamekiyo et al. 1983; Von Ammon 1987; Weirich 1989; Whitmell et al. 1987; Yarbro et al. 1976; Yusa et al. 1977). Reported Kr DFs were 100 to 1000 (Goossens et al. 1991).

When applied to dissolver off-gas, the gases must be pretreated to remove interfering constituents, thus ensuring system safety and operability. All gases that condense at liquid nitrogen temperatures or above have to be removed to prevent plugging of the equipment. These include $\mathrm{NO}_{\mathrm{x}}$, water vapor, and $\mathrm{CO}_{2}$. Oxygen must also be removed to avoid the formation and accumulation of ozone that is a radiolysis product of the radiation from ${ }^{85} \mathrm{Kr}$. Krypton and Xe are then removed from the off-gas stream in a stripping column by dissolution in liquid nitrogen. They are subsequently separated in purification columns, where the solvent is first removed along with most of the impurities and then the $\mathrm{Kr}$ is boiled off from the Xe.

A hot pilot plant cryogenic unit for the recovery of ${ }^{85} \mathrm{Kr}$ became active in 1988 in the Tokai reprocessing plant (Poncelet et al. 1991).

\subsubsection{Fluorocarbon Absorption}

Fluorocarbon absorption technology was developed at the Oak Ridge Gaseous Diffusion Plant and at the Kernforschungszentrum Karlsruhe (KfK) (Hebel and Cottone 1982; Henrich 1985; IAEA 1980; Little 1983). This process uses an organic solvent $\left(\mathrm{CCl}_{2} \mathrm{~F}_{2}\right.$ also known as Freon R-12) to selectively absorb noble gases from air or DOG streams; the noble gases are then stripped from the solvent by boiling.

The basis for this recovery process is the solubility difference that exists between the various gas compounds in the solvent chosen for the process. Process performance data has been obtained using tracer levels of ${ }^{85} \mathrm{Kr}$ in the column described above (Little 1983). Krypton recoveries greater than $99 \%$ have been demonstrated with concentration factors ranging between 1000 and 10000 . Following the 
removal of the R-12 vapors, the typical product stream consists of $\mathrm{CO}_{2}-78 \%, \mathrm{Xe}-13 \%, \mathrm{~N}_{2}-5.5 \%, \mathrm{Kr}-2.0 \%$, $\mathrm{O}_{2}-1.4 \%$ and $\mathrm{Ar}-0.1 \%$.

\subsubsection{Solid Sorbent Separation Processes}

Both activated carbon and zeolites have been studied to recover krypton from the DOG stream. One possible system uses a bed of synthetic silver mordenite (AgZ) at ambient temperatures to recover Xe. The "Xe free" gas is then chilled and passed onto a second hydrogen mordenite (HZ) column operated at $\sim-80^{\circ} \mathrm{C}$ where the $\mathrm{Kr}$ is absorbed. The $\mathrm{Kr}$ is recovered and concentrated on a third $\mathrm{HZ}$ column by temperature swing on the second column to $\sim 60^{\circ} \mathrm{C}$. The $\mathrm{Kr}$ is recovered from this third column again by temperature swing to a cold trap (Trevorrow et al. 1983). The Xe bed is regenerated at 200 to $250{ }^{\circ} \mathrm{C}$. Laboratory tests have shown DFs of 400 for $\mathrm{Kr}$ and 4000 for Xe (Pence and Chou 1981).

Industrial scale demonstration of an adsorptive chromatographic separation of krypton on activated charcoal at low temperatures (ACHAT) has been conducted at the research center Julich (KFA) in Germany (Ringel 1990). Krypton DFs of 1600 have been obtained and $\mathrm{Kr}$ purities in the final product of $>99 \%$.

Monson (1981) reports that AgZ has the highest $\mathrm{Kr}$ adsorption capacity and examined other less expensive zeolites for $\mathrm{Kr}$ recovery and non-cryogenic operating temperatures. His data show hydrogen mordenite $\mathrm{HZ}$ has a capacity of on the order of $1 \times 10^{-9}$ moles $\mathrm{Kr}$ per gm $\mathrm{HZ}$ at ambient temperatures. Munakata et al. (2003) have also examined the use of $\mathrm{AgZ}$ and $\mathrm{HZ}$ to recover $\mathrm{Xe}$ and $\mathrm{Kr}$ from helium carrier gas. They point out that this approach should have lower operating costs than cryogenic distillation and will avoid the possible fire hazard resulting from the accumulation of ozone in the cryogenic systems. It also has the advantage of avoiding the possible explosive reactions and fire risks associated with $\mathrm{NO}_{\mathrm{x}}$ reactions and activated carbons that have also been studied for the recovery of $\mathrm{Kr} / \mathrm{Xe}$. Loadings of $1 \times 10^{-6} \mathrm{~mol} \mathrm{Kr} / \mathrm{g} \mathrm{AgZ}$ and $2 \times 10^{-7} \mathrm{~mol} \mathrm{Kr} / \mathrm{g} \mathrm{HZ}$ were reported at a partial pressure of $\sim 5 \mathrm{~Pa}$. Xe loadings are estimated to be $2 \times 10^{-4} \mathrm{~mol} \mathrm{Xe} / \mathrm{g} \mathrm{AgZ}$ and $1.5 \times 10^{-5} \mathrm{~mol} \mathrm{Xe} / \mathrm{g} \mathrm{HZ}$ were reported at a partial pressure of $\sim 55 \mathrm{~Pa}$. Both of these loadings are at $273 \mathrm{~K}$. Thus processing of $1 \mathrm{tU}$ would require a minimum bed size of $\sim 500 \mathrm{~L}$ of $\mathrm{AgZ}$ at a packed density of $0.662 \mathrm{~g} / \mathrm{cm}^{3}$. At these conditions the bed would absorb $\sim 0.3 \mathrm{~mol}$ of $\mathrm{Kr}$ in addition to the $67.4 \mathrm{~mol}$ of $\mathrm{Xe}$. This is $\sim 5 \%$ of the $\mathrm{Kr}$.

Building from these data, and with the goal of operating the $\mathrm{Kr}$ recovery systems at or near room temperature, two solid sorbents are currently under evaluation as part of the Off-gas Sigma Team effort. These include several metal organic frameworks (MOF) materials (Strachan et al. 2011b, Thallapally et al. 2012, 2013; Cabe et al. 2014) and an engineered form of a synthetic AgZ/HZ (Garn et al. 2012, Garn and Greenhalgh 2013).

Recent sorbent development efforts resulted in a patented process for preparing engineered form sorbents incorporating synthetic $\mathrm{AgZ}$ and $\mathrm{HZ}$ mordenite powders bound in a macroporous polymer (Garn et al. 2014). The AgZ-PAN and HZ-PAN engineered forms have been tested at bench-scale using thermal swing and thermal/pressure swing combination operations. Xenon loadings for AgZ-PAN at room temperature $\left(22^{\circ} \mathrm{C}\right)$ of $3 \times 10^{-5} \mathrm{~mol} \mathrm{Xe} / \mathrm{g} \mathrm{AgZ}-\mathrm{PAN}$ have been achieved using a Xe partial pressure of $\sim 100 \mathrm{~Pa}$. Slightly elevating the feed gas pressure to $20 \mathrm{psig}$ increased Xe loading by a factor of nearly three at room temperature. Loadings measured at $220 \mathrm{~K}$ for Xe at $\sim 100 \mathrm{~Pa}$ and $\mathrm{Kr}$ at $\sim 15 \mathrm{~Pa}$ were $6 \times 10^{-4}$ mol Xe/g AgZ-PAN and $6 \times 10^{-6} \mathrm{~mol} \mathrm{Kr} / \mathrm{g}$ AgZ-PAN. Loadings for HZ-PAN at $220 \mathrm{~K}$ using the same Xe and $\mathrm{Kr}$ partial pressures were very similar to those with AgZ-PAN, suggesting the Xe/silver interaction is more prevalent at room temperature and HZ-PAN being less expensive can be effectively used to capture $\mathrm{Kr}$ at reduced temperatures. Recent thermal/pressure swing combination test results suggest $\mathrm{Kr}$ loadings for HZ-PAN at $220 \mathrm{~K}$ can be increased by a factor of three by elevating feed gas pressures to $30 \mathrm{psig}$.

Apart from AgZ and HZ, MOF's are being developed for the removal of $\mathrm{Xe}$ and $\mathrm{Kr}$ at near room temperature. Among all the MOF materials tested, a nickel dioxobenzenedicarboxylic acid (NiDOBDC, 
Thallapally et. al., 2012) based MOF and a partially fluorinated MOF with copper (FMOF-Cu, Fernandez et. al., 2012) have shown improved $\mathrm{Xe}$ and $\mathrm{Kr}$ capacities at room temperature relative to previous materials (Debasis et. al., 2015). Adsorption experiments on the NiDOBDC showed that it has a Xe adsorption capacity of $4.24 \mathrm{mmol} \mathrm{Xe} / \mathrm{g}$ at $100 \mathrm{kPa}$ and $298 \mathrm{~K}$. However, it only adsorbs $3 \mathrm{mass} \% \mathrm{Kr}$ $\left(3.57 \times 10^{-4} \mathrm{~mol} \mathrm{Kr} / \mathrm{g}\right)$ under similar experimental conditions. However, the silver nanoparticle-loaded NiDOBDC (Ag@NiDOBDC) had better Xe uptake capacity $\left(5.3 \times 10^{-3} \mathrm{~mol} \mathrm{Xe} / \mathrm{g}\right)$ and selectivity $(\mathrm{Xe} / \mathrm{Kr}$ $\approx 7$ ) over the parent framework (Liu et. al., 2014). Under the same conditions (room temperature and 100 $\mathrm{kPa}$ ) the FMOFCu adsorbed $4.5 \times 10^{-4} \mathrm{~mol} \mathrm{Xe} / \mathrm{g}$ and $3.4 \times 10^{-5} \mathrm{~mol} \mathrm{Kr} / \mathrm{g}$. However under low temperatures $\left(-40^{\circ} \mathrm{C}\right)$ the $\mathrm{FMOFCu}$ adsorbed higher $\mathrm{Kr}\left(1.75 \times 10^{-3} \mathrm{~mol} \mathrm{Kr} / \mathrm{g}\right)$ than $\mathrm{Xe}\left(1.5 \times 10^{-4} \mathrm{~mol}\right.$ $\mathrm{Xe} / \mathrm{g})$ at $100 \mathrm{kPa}$ (Fernandez et. al., 2012).

The removal efficiency and capacity of NiDOBDC and FMOF-Cu for $\mathrm{Kr}$ recovery with two adsorption beds in series at a non-cryogenic temperature $(233 \mathrm{~K})$ has been demonstrated (Liu et. al., 2014). The use of $233 \mathrm{~K}$ was strictly an artifact of the experimental set-up used here. Independently, these MOFs have been shown to have high capacities and specificities for Xe and $\mathrm{Kr}$ at temperatures $>273 \mathrm{~K}$. Passing a mixture of $400 \mathrm{ppm} \mathrm{Xe}, 40 \mathrm{ppm} \mathrm{Kr}$ in dry air through bed 1 containing NiDOBDC shows the selective capture of $\mathrm{Xe}$, the outlet gas mixture from bed 1 now containing $40 \mathrm{ppm} \mathrm{Kr}$ in air is then passed through bed 2 also containing NiDOBDC where $\mathrm{Kr}$ is removed $(0.61 \mathrm{mmol} / \mathrm{kg})$. Similar experiments performed with FMOFCu instead of NiDOBDC in bed 2 result in adsorption capacities 3.7 times for $\mathrm{Kr}(1.03$ $\mathrm{mmol} / \mathrm{kg}$ ) than from mixture containing $\mathrm{Xe}$ and $\mathrm{Kr}$. Based on these results, a two bed system used for a $1000 \mathrm{tU} / \mathrm{y}$ plant would require a $1.9 \mathrm{~m}^{3} \mathrm{Xe}$ bed and a $5.6 \mathrm{~m}^{3} \mathrm{Kr}$ bed (Cabe et al. 2014). These results show that MOF materials continue to be promising for separation of $\mathrm{Xe}$ and $\mathrm{Kr}$ from air and from each other at non-cryogenic temperatures.

Apart from MOFs, PNNL collaborated with University of Liverpool, UK to explore the applicability of porous organic cage compound (CC3) for separation of $\mathrm{Xe}$ and $\mathrm{Kr}$ at room temperature (Chen et. al, 2014). In the solid state, CC3 molecules pack to give a robust 3-dimensional pore structure with porelimiting diameter of just $3.6 \AA$. This is slightly smaller than the diameter of $\mathrm{Kr}$ (3.69 $\AA$ ) (Van Heest et al. 2012), and in principle too narrow to permit the diffusion of Xe. Therefore adsorption experiments at room temperature using $\mathrm{Xe}$ and $\mathrm{Kr}$ were carried at $100 \mathrm{kPa}$. The Xe isotherm approaches saturation at $100 \mathrm{kPa}(298 \mathrm{~K})$ with an adsorption capacity of around $2.25 \times 10^{-3} \mathrm{~mol} \mathrm{Xe} / \mathrm{g}$, corresponding to three gas molecules per CC3 cage. Similarly, the adsorption capacity of $\mathrm{Kr}$ at identical conditions was found to be $0.84 \times 10^{-3} \mathrm{~mol} \mathrm{Kr} / \mathrm{g}$. When air containing Xe (400 ppm) and $\mathrm{Kr}(40 \mathrm{ppm})$ was passed through this column (start at $10 \mathrm{~min}$ ), the Xe component was retained for more than 15 minutes, even at a flow rate of $0.67 \mathrm{~L} / \mathrm{s}$ or twice as fast as that used in the studies of NiDOBDC (Liu et. al., 2012), whereas $\mathrm{Kr}$ and the other components $\left(\mathrm{N}_{2}, \mathrm{O}_{2}\right.$, and $\left.\mathrm{CO}_{2}\right)$ broke through the column almost immediately. Under these conditions, $\mathrm{CC} 3$ adsorbs twice $(11 \mathrm{mmol} / \mathrm{kg}$ ) as much $\mathrm{Xe}$ as the leading MOF, Ni/DOBDC $(4.8 \mathrm{mmol} \mathrm{kg}$ $\left.{ }^{1}\right)$. Likewise, the $\mathrm{Xe} / \mathrm{Kr}$ selectivity for $\mathrm{CC} 3$ under these conditions is almost three times higher than for Ni/DOBDC: 20.4 versus 7.3. This is ascribed to the near-perfect fit between the cavities in CC3 and the $\mathrm{Xe}$ guests.

\subsubsection{Summary and Recommendations}

A summary of $\mathrm{Kr}$ recovery processes is shown in Table 2.4. Based on the technical maturity and effectiveness, it is recommended that cryogenic distillation be the primary process for $\mathrm{Kr}$ recovery. However, adsorption processes have shown promise to be cost effective alternatives and should be developed further and demonstrated. 
Table 2.4. Summary of Krypton Recovery Processes.

\begin{tabular}{|c|c|c|c|c|}
\hline $\begin{array}{c}\text { Material / } \\
\text { Process } \\
\end{array}$ & Process Conditions: & $\begin{array}{c}\text { Decontamination } \\
\text { Factor } \\
\end{array}$ & $\begin{array}{l}\text { Capacity of } \\
\text { Adsorbent: }\end{array}$ & $\begin{array}{c}\text { Level of } \\
\text { Development: }\end{array}$ \\
\hline $\begin{array}{l}\text { Cryogenic } \\
\text { Distillation }\end{array}$ & $\begin{array}{l}\text { All gas components that } \\
\text { are subject to } \\
\text { freezing must be } \\
\text { removed }\left(\mathrm{NO}_{\mathrm{x}}, \mathrm{H}_{2} \mathrm{O}\right. \\
\left.\text { and } \mathrm{CO}_{2}\right) \text {. } \\
\text { Oxygen must be } \\
\text { removed prior to } \\
\text { operation } \\
\text { Pretreat to }-170^{\circ} \mathrm{C} \\
\text { Pressurized system }\end{array}$ & $60-1000$ & $\begin{array}{l}\text { Variable, but depends } \\
\text { on the radiation } \\
\text { dose to workers. }\end{array}$ & $\begin{array}{l}\text { Cryogenic distillation } \\
\text { for rare gases is } \\
\text { commercial } \\
\text { technology. } \\
\text { Pilot-scale cryogenic } \\
\text { units for } \mathrm{Kr} \text { recovery } \\
\text { in the absence of } \mathrm{O}_{2} \\
\text { have been tested. }\end{array}$ \\
\hline $\begin{array}{l}\text { Fluorocarbon } \\
\text { Absorption } \\
\left(\mathrm{CCl}_{2} \mathrm{~F}_{2}, \mathrm{R}-12\right)\end{array}$ & $\begin{array}{l}\text { Three unit operations } \\
\text { are required - } \\
\text { absorption, } \\
\text { intermediate } \\
\text { stripping, and final } \\
\text { stripping. } \\
\text { Pretreat to }-150^{\circ} \mathrm{C} \\
\text { Atmospheric or below }\end{array}$ & $\begin{array}{l}100-1000 \text { for } \mathrm{Kr} \\
\mathrm{Xe} / \mathrm{Kr} \text { separation factor } \\
\quad \text { of } 10^{6} \\
\mathrm{Kr} \text { purity of }>99 \% \\
\text { Also recovers } \mathrm{CO}_{2}, \mathrm{NO}_{\mathrm{x}}\end{array}$ & Low inventory & $\begin{array}{l}\text { Technology has } \\
\text { proceeded through } \\
\text { several generations } \\
\text { of pilot-scale } \\
\text { development. }\end{array}$ \\
\hline $\begin{array}{l}\text { Solid sorbent } \\
\text { adsorption (Silver } \\
\text { and Hydrogen } \\
\text { mordenite AgZ and } \\
\text { (HZ) and activated } \\
\text { charcoal }\end{array}$ & $\begin{array}{l}\text { Cool to }-80^{\circ} \mathrm{C} \\
\text { Atmospheric or below }\end{array}$ & $\begin{array}{l}1000-\mathrm{Kr} \text { (charcoal at - } \\
\left.150^{\circ} \mathrm{C}\right), \\
400-\mathrm{Kr}\left(\mathrm{HZ} \text { at }-80^{\circ} \mathrm{C}\right) \\
\text { Separation factors } \sim 5 \% \\
\text { of } \mathrm{Kr} \text { retained with } \\
\mathrm{Xe}-\text { further } \\
\text { separations may be } \\
\text { required } \\
\end{array}$ & $\begin{array}{l}\mathrm{HZ}: 10^{-3} \mathrm{mmol} / \mathrm{kg} \text { at } \\
25^{\circ} \mathrm{C} ; 0.1 \mathrm{mmol} / \mathrm{kg} \\
\text { at } 0^{\circ} \mathrm{C} ; 25 \mathrm{mmol} / \mathrm{kg} \\
\text { at }-75^{\circ} \mathrm{C} \text { (all at } \mathrm{Kr} \\
\text { partial pressures of } \\
10 \mathrm{~Pa})\end{array}$ & $\begin{array}{l}\text { The technology has been } \\
\text { tested at small } \\
\text { engineering scale } \\
\text { Selectivity is an issue }\end{array}$ \\
\hline $\begin{array}{l}\text { Solid sorbents for } \\
\text { high temperature } \\
\text { application }\end{array}$ & $\begin{array}{l}\text { Two columns } \\
\text { containing MOFs } \\
\text { and operated at } 0 \\
{ }^{\circ} \mathrm{C} \text {. The first } \\
\text { column is used to } \\
\text { remove } \mathrm{Xe} \text {; the } \\
\text { second } \mathrm{Kr} \text {. }\end{array}$ & 100 for both $\mathrm{Xe}$ and $\mathrm{Kr}$ & $\begin{array}{l}2 \mathrm{mmol} / \mathrm{kg} \text { for } \mathrm{Xe} \\
0.8 \mathrm{mmol} / \mathrm{kg} \text { for } \mathrm{Kr}\end{array}$ & $\begin{array}{r}\text { Laboratory scale } \\
\text { development }\end{array}$ \\
\hline
\end{tabular}

\subsubsection{Krypton Stabilization}

Options evaluated include decay storage in pressure containers and immobilization in solid matrices. The target for both of these approaches is to manage ${ }^{85} \mathrm{~K}$ for less than 100 years. For the purposes of this study, the equipment used for $\mathrm{Kr}$ and Xe recovery isn't precisely identified. A DF of 400 for $\mathrm{Kr}$ and 1000 for Xe are assumed with separation factors of $99.9 \%$ for $\mathrm{Kr}$ from Xe and $95 \%$ of Xe from $\mathrm{Kr}$. 10 vol\% $\mathrm{H}_{2}$ will also remain in the gas mixture from $\mathrm{O}_{2}$ reduction. Such a process would produce a gas stream containing $540 \mathrm{~g} \mathrm{Kr}, 104 \mathrm{~g} \mathrm{Xe}$, and $1.59 \mathrm{~g} \mathrm{H}_{2}$ per tU processed for a total of $645 \mathrm{~g} / \mathrm{tU}$ for the reference fuel cooled for $5 \mathrm{y}$.

\subsubsection{Pressure Cylinders}

The simplest solution for the management of ${ }^{85} \mathrm{Kr}$ is decay storage in compressed gas cylinders. While this method provides an easy storage option, it also increases the potential release hazard. Containers must remain intact for $\sim 100$ years, resist corrosion due to the in-growth of chemically aggressive $\mathrm{Rb}$ and dissipate the decay heat. Low pressure cylinders $(50 \mathrm{~atm})$ are attractive from the stand point of reducing the risk of large gas releases in the event of cylinder rupture but, require larger storage volume. The use of high pressure cylinders $(500+$ atm, ultimately limited by heat) reduces the volume with the acceptance 
of some risk from cylinder leakage and rupture. The overall storage volume ranges from 0.95 (163 atm) to $3.7(50 \mathrm{~atm}) \mathrm{L} / \mathrm{tU}$. Secondary containment may be required for gas cylinders as it's impractical to perform $\mathrm{Kr}$ capture on a canister storage facility sweep gas.

\subsubsection{Ion Implantation}

Encapsulation in a metal matrix has been explored by the US, UK, and FRG. In the US process, the krypton is incorporated into a sputtered metal matrix at pressures on the order of $0.4 \mathrm{~Pa}$ (McClanahan et al. 1986 and Whitmell et al. 1980). The sputtered metal matrix will contain 5-6\% $\mathrm{Kr}$ on an atomic level. The product is an amorphous glassy deposit. Loadings of 16-20 liters at STP per kg metal matrix could be achieved (Thijs and Vansant, 1987). The UK process uses copper as the metal matrix and has resulted in a half scale inactive plant which the Atomic Energy Research Establishment (AERE) at Harwell has had built and designed to treat a $1500 \mathrm{t} / \mathrm{yr}$ plant. Loadings of $20-25$ liters of $\mathrm{Kr} / \mathrm{kg}$ metal could be achieved. The process developed at Karlsruhe, Germany, combines features of both the US and UK approaches, and achieves lower power requirements than the UK process. The primary differences between these processes are the nature of the products and the means of creating the plasma.

\subsubsection{Zeolite Encapsulation}

An alternative process for ${ }^{85} \mathrm{Kr}$ storage is encapsulation in a zeolite matrix. Krypton loadings of $50 \mathrm{~m}^{3}$ at STP per cubic meter solid are readily achieved at $100 \mathrm{MPa}$ in zeolite $5 \mathrm{~A}$ at $700^{\circ} \mathrm{C}$. The $\mathrm{Kr}$ is encapsulated in the zeolite structure by hot-isostatic pressing where the pores of the zeolite are sealed. The relatively low thermal conductivity of the zeolite should be considered, as it may limit the maximum Kr loading (Penzhorn et al. 1980).

\subsubsection{Summary and Recommendations}

A summary of krypton stabilization processes is shown in Table 2.5. Based on the results of these studies, it is recommended that low-pressure storage in compressed gas cylinders be assumed until full plant engineering and safety analyses can be performed. GNEP studies also recommended low-pressure gas cylinder storage for $\mathrm{Kr}$, although processing of older fuel would allow for direct release and no need for capture or storage.

Table 2.5. Summary of Krypton Stabilization Methods.

\begin{tabular}{|l|l|l|l|}
\hline Form & Loading/pressure & Volume L/tUd & Issues \\
\hline Low Pressure cylinder & $50 \mathrm{Atm}$ & 3.7 & Volume \\
\hline High Pressure cylinder & $163 \mathrm{Atm}$ & 1.1 & $\begin{array}{l}\text { Corrosion due to Rb, Pressure, Heat } \\
\text { dissipation }\end{array}$ \\
\hline Zeolite & $50 \mathrm{~m}^{3} / \mathrm{m}^{3}$ & 2.8 & High Temperature / High Pressure operation \\
\hline Ion Implantation & $20-25 \mathrm{~L} \mathrm{Kr} / \mathrm{kg}$ metal & $\begin{array}{l}0.78 \text { (assuming } \\
\text { Cu Metal } \\
\text { matrix) }\end{array}$ & $\begin{array}{l}\text { Complexity } \\
\text { Higher Cost }\end{array}$ \\
\hline \begin{tabular}{l}
$|l|$ \\
\hline
\end{tabular} \\
$\begin{array}{l}\text { a. Assumes Ideal Gas Law applies (making cylinder volumes conservatively high), and } 80^{\circ} \mathrm{C} \text { temperature due to decay heat } \\
\text { inside cylinders. } \\
\text { b. Assumes Kr/Xe separation. Could be up to 11 times greater if not separated. }\end{array}$ \\
\hline
\end{tabular}

\subsection{Carbon-14}

The required ${ }^{14} \mathrm{C}$ DF is highly dependent on fuel processed and assumptions on plant design and may be as low as 1 or as high as 10 (Jubin et al. 2012a). The estimated concentration of ${ }^{14} \mathrm{C}$ in the reference fuel (Table 1.1) is $0.3 \mathrm{~g} / \mathrm{tU}$, or in the oxidized form $0.95 \mathrm{~g} / \mathrm{tU}^{14} \mathrm{CO}_{2}$. Estimates of ${ }^{14} \mathrm{C}$ release from the 
standard TPT process is roughly $50 \%$ (Table 1.2 ). The fraction of ${ }^{14} \mathrm{C}$ released from the dissolver may be between 50 and $100 \%{ }^{\mathrm{d}}$ For the purposes of estimating waste form volumes, it is assumed that $100 \%$ of the ${ }^{14} \mathrm{C}$ is released to the DOG in the reference case and $50 \%$ is released to the TOG and the other $50 \%$ is released to the DOG in the case of the advanced flowsheet. The amounts of tramp ${ }^{12} \mathrm{CO}_{2}$ coming from shear sweep gas and dissolver air inleakage and sparging were calculated assuming air flowrates of 5,830 $\mathrm{m}^{3} / \mathrm{d}$ through the shear cell and $6650 \mathrm{~m}^{3} / \mathrm{d}$ though the dissolver (it is assumed that $\mathrm{CO}_{2}$-free air would be used in the TPT). This would result in $9.16 \mathrm{~kg} / \mathrm{d}$ of ${ }^{12} \mathrm{CO}_{2}$ or $1.83 \mathrm{~kg} / \mathrm{tU}$ (for a nominal $5 \mathrm{tU} / \mathrm{d}$ plant). The result is a dilution of ${ }^{14} \mathrm{CO}_{2}$ by ${ }^{12} \mathrm{CO}_{2}$ of roughly 1925:1.

\subsubsection{Carbon Capture}

There are a number of technologies that have been developed for $\mathrm{CO}_{2}$ removal. These include caustic scrubbing, molecular sieve adsorption, adsorbent bed fixation, and co-absorption and concentration in conjunction with $\mathrm{Kr}$ recovery and subsequent immobilization. There is sufficient cold-engineering results that indicate these methods would work. However, their practicality in radioactive application remains for the most part untested.

\subsubsection{Caustic Scrubbing}

Carbon dioxide adsorption in a caustic solution in a packed column to form carbonates is a common industrial process that has been described in detail (Bray 1977). While the process has never been applied specifically for ${ }^{14} \mathrm{C}$ recovery in the nuclear fuel cycle, the EPA indicated in 1977 that it would be the most probable candidate for application at that time (Brown et al. 1983). The baseline process is scrubbing with $\mathrm{Ca}(\mathrm{OH})_{2}$ because of the greater solubility and lower cost compared to the more efficient $\mathrm{Ba}(\mathrm{OH})_{2}$.

A double-alkali process involving $\mathrm{Na}_{2} \mathrm{CO}_{3}$ and $\mathrm{CaCO}_{3}$ is briefly described in the book edited by Goosens (1991). Carbon dioxide is initially scrubbed from the off-gas stream with an aqueous $\mathrm{NaOH}$ stream to form $\mathrm{Na}_{2} \mathrm{CO}_{3}$. The resulting solution is then reacted with lime $(\mathrm{CaOH})$ to produce a solid $\mathrm{CaCO}_{3}$ product.

\subsubsection{Caustic Slurry Scrubbing}

Limited studies have been made into the use of alkaline earth hydroxide slurry in stirred tank reactors to absorb $\mathrm{CO}_{2}$ (Notz 1980). The DF for $\mathrm{Ba}(\mathrm{OH})_{2} \cdot 8 \mathrm{H}_{2} \mathrm{O}$ is about 10 times greater than $\mathrm{Ca}(\mathrm{OH})_{2}$, which is about 10 times greater than $\mathrm{Mg}(\mathrm{OH})_{2}$. The reaction rates were determined to be controlled by transport in the aqueous phase and thus impacted by the hydrodynamic parameters of the reactor. Processing steps to recover the spent material, dry, and package in a suitable waste form remains to be completed (Brown et al. 1983).

\footnotetext{
${ }^{\mathrm{d}}$ In the THORP facility, it is reported (Chris Phillips personal communication) that $\sim 98 \%$ of the ${ }^{14} \mathrm{C}$ in the fuel is released during dissolution. However, information from AREVA indicates that only $\sim 50 \%$ of the ${ }^{14} \mathrm{C}$ is released during dissolution. The THORP dissolver is a batch design with a long residence time. The AREVA dissolver is a continuous 'bucket wheel' design which probably has a shorter residence time. The implication is that ${ }^{14} \mathrm{C}$ release during dissolution is highly dependent on residence time.
} 


\subsubsection{Molecular Sieve Adsorption}

The adsorption of $\mathrm{CO}_{2}$ on packed adsorbent beds is a common industrial process. The 4A molecular sieve has been demonstrated at laboratory scale to remove the $\mathrm{CO}_{2}$ down to the level of detection (10 ppm) from a $>90 \% \mathrm{CO}_{2}$ stream. The bed is regenerated by heating it to $200{ }^{\circ} \mathrm{C}$.

This process has not been applied to ${ }^{14} \mathrm{C}$ recovery in the nuclear fuel cycle, but process flow sheets have been proposed for full-scale application (Brown et al. 1983; DOE 1979). The adsorption technology would have to be coupled to another technology such as caustic scrubbing followed by mixing the solid product with cement to provide a solid waste form.

\subsubsection{Adsorbent Bed Fixation}

Pilot scale studies have been conducted by researchers at Ontario Hydro on a gas-solid reaction process to remove ${ }^{14} \mathrm{C}$ on beds of either $\mathrm{Ca}(\mathrm{OH})_{2}$ or $\mathrm{Ba}(\mathrm{OH})_{2} \cdot 8 \mathrm{H}_{2} \mathrm{O}$ (Chang et al. 1991; Cheh 1985; Dayal and Reardon 1992; Kabat 1979; Stasko and Vivian 1982). Engineering details for the removal of the waste from the reactor vessel and putting it into a final immobilized form such as cement remain to be done.

\subsubsection{Summary and Recommendation}

A summary of ${ }^{14} \mathrm{C}$ recovery processes is shown in Table 2.6. THORP uses a caustic scrub and then reaction with barium nitrate to precipitate barium carbonate which is grouted to produce a storable waste form. This has been successfully used since 1994 under fully radioactive conditions and while processing at the industrial scale of $5 \mathrm{tU} / \mathrm{d}$ (Hudson et al. 1995). This industrial success coupled with adequate DF and simple processes make caustic scrubbing the recommended process. $\mathrm{A} \mathrm{CO}_{2} \mathrm{DF}$ of 50 will be assumed in this study.

Table 2.6. Summary of Carbon Recovery Processes.

\begin{tabular}{|c|c|c|c|c|}
\hline Material / Process & Process Conditions & $\begin{array}{c}\text { Decontamination } \\
\text { Factor } \\
\end{array}$ & $\begin{array}{c}\text { Capacity of } \\
\text { Adsorbent }\end{array}$ & Level of Development \\
\hline Caustic scrubbing & $\begin{array}{l}\mathrm{NO}_{\mathrm{x}} \text { and iodine should be } \\
\text { removed to avoid } \\
\text { added waste volume } \\
\text { and complications. }\end{array}$ & $10-100$ & & $\begin{array}{l}\text { Common industrial } \\
\text { process }\end{array}$ \\
\hline $\begin{array}{l}\text { Caustic } \mathrm{Ca}(\mathrm{OH})_{2} \\
\text { Slurry Scrubbing }\end{array}$ & $\begin{array}{l}\mathrm{NO}_{\mathrm{x}} \text { and iodine should be } \\
\text { removed to avoid } \\
\text { added waste volume } \\
\text { and complications. }\end{array}$ & $\begin{array}{l}\mathrm{Ba}(\mathrm{OH}) 2 \cdot 8 \mathrm{H} 2 \mathrm{O} \\
\text { has } 10 \text { times DF } \\
\text { of } \mathrm{Ca}(\mathrm{OH}) 2\end{array}$ & & $\begin{array}{l}\text { Technology has proceeded } \\
\text { through several } \\
\text { generations of pilot- } \\
\text { scale development. }\end{array}$ \\
\hline $\begin{array}{l}\text { Solid sorbent } \\
\text { adsorption (molecular } \\
\text { sieve } 4 \mathrm{~A} \text { ) }\end{array}$ & $\begin{array}{l}\mathrm{NO}_{\mathrm{x}} \text { and water should be } \\
\text { removed. } \\
\text { Must be coupled with } \\
\text { caustic scrub to } \\
\text { recover trapped } \mathrm{CO}_{2} \text {. }\end{array}$ & $\begin{array}{l}>100 \\
\text { Does not adsorb } \mathrm{Kr} \\
\text { like 5A sieve at } \\
\text { ambient } \\
\text { temperatures } \\
\end{array}$ & & $\begin{array}{l}\text { Packed bed adsorption is } \\
\text { common industrial } \\
\text { practice. } \\
\text { Has not been applied to } \\
\text { nuclear applications }\end{array}$ \\
\hline $\begin{array}{l}\text { Adsorbent Bed } \\
\text { Fixation }\left(\mathrm{Ca}(\mathrm{OH})_{2}\right)\end{array}$ & & 20 & $\begin{array}{l}63 \% \text { conversion of } \\
\text { bed for }\end{array}$ & $\begin{array}{l}\text { The technology has been } \\
\text { tested at pilot / } \\
\text { engineering scale }\end{array}$ \\
\hline $\begin{array}{l}\text { Adsorbent Bed } \\
\text { Fixation } \\
\left(\mathrm{Ba}(\mathrm{OH})_{2} \bullet 8 \mathrm{H}_{2} \mathrm{O}\right)\end{array}$ & & $>3000$ & $\begin{array}{l}\text { Up to } 99 \% \\
\text { conversion of bed } \\
\text { for }\end{array}$ & $\begin{array}{l}\text { The technology has been } \\
\text { tested at small } \\
\text { engineering scale }\end{array}$ \\
\hline
\end{tabular}




\subsubsection{Carbon Stabilization}

Most of the carbon immobilization studies conducted to date have considered calcium or barium carbonate that is then mixed with cement and packaged in steel drums. ${ }^{\mathrm{e}}$ This is also the industrial process applied at THORP. Precipitation of the carbonate by calcium is less expensive than barium and avoids issues associated with the hazardous waste generated from barium handling and use. Cementation was also recommended in the GNEP studies in the cases were ${ }^{14} \mathrm{C}$ capture was considered.

The process, as described by Holladay (1978) and Goosens (1991), is to capture $\mathrm{CO}_{2}$ in a 1.5 to $1.7 \mathrm{M}$ $\mathrm{NaOH}$ solution. $\mathrm{CaOH}$ is added to the solution to precipitate $\mathrm{CaCO}_{3}$ which is concentrated to $800 \mathrm{~g} / \mathrm{L}$ $\left(\mathrm{CaCO}_{3}\right)$. The liquid phase of the $\mathrm{CaCO}_{3}$ slurry will contain a nominal $1.6 \mathrm{M} \mathrm{NaOH}$. This scrubber would also remove a portion of whatever $\mathrm{NO}_{\mathrm{x}}$ is in the gas stream. There may be some effect of dissolved ions $\left(\mathrm{Na}^{+}, \mathrm{NO}_{2}{ }^{-}, \mathrm{NO}_{3}^{-}, \mathrm{OH}^{-}\right.$, etc.) on the solubility of $\mathrm{CaCO}_{3}$. Lacking specific data $0 \%$ dissolved $\mathrm{CaCO}_{3}$ is assumed; although it is recognized that there may be some dissolved $\mathrm{CaCO}_{3}$ circulating in the scrub system.

The annual waste product from the scrubber column would be $1.6 \mathrm{t}$ of calcium carbonate containing $\sim 2 \mathrm{~kg}$ of $\mathrm{Ca}^{14} \mathrm{CO}_{3}$. The mass of this aqueous slurry is expected to be $20 \mathrm{t}$ which, if immobilized in cement at a ratio of $30 \%$ slurry to $70 \%$ cement, would generate 65 t of cement or 190 drums (200 L capacity) of waste product. To reduce the impact of non-radioactive $\mathrm{CO}_{2}$, the process could be designed to remove the $\mathrm{CO}_{2}$ from the air prior to sparging the dissolver, minimizing sparge gas flow, or using nitrogen in place of air.

Section 9 describes the cementation process and also discusses the possibility of combining the $\mathrm{CaCO}_{3}$ waste with other wastes for cementation.

\subsection{Data Gaps and Research Needs}

The development of an integrated reprocessing plant off-gas treatment system that efficiently meets all of the regulatory requirements is a significant challenge, for both aqueous and other reprocessing technologies. New materials and methods promise to improve the ability to effectively meet those requirements. However, most of these methods are not fully technically mature and the unit operations have not been integrated into a working system. The data gaps and research needs are given below first for individual unit operations and then for integrated off-gas treatment systems.

\subsubsection{Tritium}

- Demonstrate the process for obtaining a clean separation between ${ }^{129} \mathrm{I}$ and ${ }^{3} \mathrm{H}$ during treatment of prototypic simulated off-gas streams at laboratory scale. Follow-up with integrated cold- and hotoff-gas system testing described below.

- Processes under current investigation to support air/oxygen based tritium pretreatment of UNF include sorption on MS3A to sequester the tritiated water. The high concentrations of NOx in the off-gas could cause the tritium to be partially converted to tritiated nitric acid vapor. Information needed to support the $\mathrm{NO}_{2}$ pretreatment process includes, but is not limited to, the speciation of tritium in the off-gas stream (e.g, ${ }^{3} \mathrm{HHO},{ }^{3} \mathrm{HNO}_{3},{ }^{3} \mathrm{HNO}_{2}$, etc.) and the capacity of the MS3A sorbent to sequester the tritium-bearing compounds. Alternatives to MS3A may need to be identified that are more compatible with nitric or other acid gases.

e Leach tests conducted by Scheele and Burger (1982) have shown leach data indicating that $\sim 1 \%$ of the ${ }^{14} \mathrm{C}$ would be leached in 1000 years. A carbonate loading of $2.5 \mathrm{mmol}$ per gram of dry cement was tested. 


\subsubsection{Iodine}

- Determine the iodine species (e.g., $\mathrm{I}_{2}, \mathrm{HI}$, and $\mathrm{CH}_{3} \mathrm{I}$ ) expected from each of the key off-gas streams (DOG, HOG, TOG, VOG and MOG) and develop prototypic gas simulants for each of these streams.

- Demonstrate the efficiency of $\mathrm{AgZ}$ and alternate sorbents under increasing more prototypic offgas stream conditions to capture/control of the iodine species that will be present in DOG, HOG, TOG, VOG and MOG streams. The focus of this effort will be on organic iodides and very dilute streams. Data needed includes changes in capacity and capture efficiency as a function of stream conditions. Evaluate performance of Ag-functionalized aerogels for adsorbing iodine under prototypic off-gas conditions.

- Successfully stabilize iodine and/or iodine loaded sorbents in a matrix suitable for disposal. Determine "optimum" processing conditions and loading. This includes GCM for iodine loaded AgZ, HIPing of iodine loaded AgZ, and consolidation of iodine loaded AgAero. Determine composition of effluent from conversions process, i.e., iodine loss. Determine the effect of residuals, such as organics, on waste form fabrication process.

- Obtain data from the dissolution of actual UNF to evaluate the iodine evolution kinetics, the fraction remaining in solution, and the species of iodine not evolved.

- Determine long term performance of promising alternate iodine sorbents under operating conditions. Determine extent of co-adsorption on these materials.

- Determine the fate and behavior of iodine in used fuel during electrochemical reprocessing, specifically during the drawdown processes.

\subsubsection{Carbon}

- Determine the overall off-gas generation rate from a reprocessing plant using data from existing facilities. Determine what physical and chemical form contaminants are generated and released from these plants. Determine if ${ }^{14} \mathrm{C}$ capture will be required and to what efficiency.

- Perform a trade study to determine if $\mathrm{CO}_{2}$-free air should be utilized in a reprocessing facility to avoid generation of high volumes of ${ }^{14} \mathrm{C}$ related wastes.

- Determine the fate and behavior of carbon in used fuel during echem reprocessing.

\subsubsection{Krypton}

- Demonstrate a multi-bed system for the recovery of $\mathrm{Kr}$ from air at room temperature with MOF and zeolite materials. Confirm capacity, adsorption rates, desorption rates, etc. as a function of capture temperatures.

- Understand long term effects of the build-up of $\mathrm{Rb}$ in $\mathrm{Kr}-85$ storage systems. Continue the analysis of the legacy $\mathrm{Kr}-85$ capsules. Prepare new samples for extended storage.

- Demonstrate the radiation stability of $\mathrm{Kr}$ capture and storage MOFs. Need to understand long term stability when loaded with Kr-85. 


\subsubsection{Interfaces and Integration}

- Demonstrate integration of individual off-gas capture systems at bench scale or larger. Evaluate the combined system efficiency; determine sequencing, co-adsorption / interoperability issues.

- As currently envisioned, the $\mathrm{NO}_{2}$ tritium pretreatment process utilizes a closed loop of recirculating oxidant gas into which the volatile fission products would accumulate. The recovery of the volatile radionuclides from a gas matrix of this nature has never been demonstrated. The current choice for iodine recovery is silver exchanged mordenite which is acid stable but it has not been tested for iodine capture from gas streams containing more than a few \% NOx. Testing and verification of capture performance is needed. There is a need to identify and evaluate alternative media/processes to capture the iodine. This media needs to be insensitive to NOx and nitric acid vapors that will be present in the off-gas stream and be sufficiently selective to iodine. Current studies have shown significant degradation of AgZ under advanced tritium pretreatment off-gas conditions. An alternate iodine capture method for this application is needed. A molten $\mathrm{NaOH}$ scrubber has been proposed as a possible approach that would not be impacted by the oxidant in the gas stream. Other systems using silver nitrate may also be promising and will be examined for their efficacy.

- In addition to the volatile species, the behavior of the semi-volatile elements needs to be evaluated. The semivolatiles that arise in head-end pretreatment processes need to be identified, and the amounts in the off-gas stream quantified and the effects (if any) that high concentrations of the oxidant have on forming volatile compounds at relevant tritium pretreatment conditions need to be characterized. Of initial interest is the behavior of ruthenium under advance tritium pretreatment conditions.

- Perform a volatile species material balance on an intact fuel pin as the pin is processed through shearing, tritium pretreatment, and dissolution. Quantification of the release of semi-volatiles is also needed.

- Obtain data from plant operations through international collaboration on iodine emissions (origins and speciation).

- Demonstrate off-gas capture technologies on hot off-gas streams. This could be accomplished as opportunities become available in the US or through international collaborations. 


\section{AQUEOUS HIGH LEVEL WASTE STREAMS}

The HLW is composed of the following process streams from the processing steps to recover $\mathrm{U}$ and $\mathrm{Pu}$ from UNF:

- a HLW raffinate from TRUEX, which contains the alkali, alkaline earth, and transition metal fission products;

- a separate $\mathrm{Tc}$ solution from the third segment of the $\mathrm{U} / \mathrm{Pu} / \mathrm{Np}$ co-decontamination process;

- a lanthanide stream from TALSPEAK;

- undissolved solids from dissolver sludge and solution clarification, containing primarily Mo, Tc, $\mathrm{Ru}, \mathrm{Rh}, \mathrm{Pd}, \mathrm{Zr}, \mathrm{Te}, \mathrm{O}$, and $\mathrm{Pu}$.

The compositions of these streams are given in Table 1.5.

This section begins with a discussion of the waste forms that have been considered for HLW immobilization and the evaluations that have led to borosilicate glass as the preferred immobilization method with Synroc crystalline ceramic as the next option for defense HLW. Then details of the HLW vitrification process are provided. Finally, alternative candidate waste forms and processes with the potential for significant advantages over the baseline borosilicate glass are presented.

\subsection{HLW Waste Form Reviews}

Borosilicate glass in a stainless steel canister is the baseline waste form for immobilization and disposal of HLW in the U.S. and most of the rest of the world. Synroc (i.e. synthetic rock) (Ringwood et al. 1980; Ringwood et al. 1981) is a synthetic crystalline ceramic that is considered as an option to the baseline glass. Numerous other waste forms have been considered over the years for HLW immobilization.

In the U.S., the DOE and its predecessors have been conducting waste form and waste immobilization process development and evaluation dating back to the 1950's (Durham 1957; Ginell et al. 1954; Goldman et al. 1957; Hatch 1953; Manowitz and Hatch 1954; Watson et al. 1958; White and Lahaie 1955). From 1966 to 1970, the Waste Solidification Engineering Prototypes program demonstrated pot calcine, phosphate microcrystalline ceramic, phosphate glass, and borosilicate glass for immobilization of commercial HLW (Schneider and Kelly 1969, Schneider 1969, McElroy et al. 1972, Mendel and McElroy 1972).

Between 1979 and 1981, DOE conducted its National High-Level Waste Technology Program to develop and evaluate candidate waste forms for immobilization of HLW at DOE defense sites (Gray 1981). Table 3.1 lists the 17 waste forms initially considered for development and evaluation. By the end 1981, seven candidate waste forms had been selected including (Hench et al. 1981):

- Borosilicate glass

- Synroc

- Tailored ceramic

- High-silica glass

- FUETAP Concrete

- Coated particles

- Glass marbles in a lead matrix

Based on waste form evaluations conducted at the DOE national laboratories and independent laboratories, peer review assessments, a product performance evaluation, and a processability assessment, 
borosilicate glass and Synroc were selected as the reference and alternate waste forms (Hench et al. 1979, 1980a,b). The peer review was conducted by the Alternative Waste Form Peer Review Panel which ranked borosilicate glass highest and Synroc second. Building on this evaluation and conducting the National Environmental Protection Act (NEPA) process, borosilicate glass was selected for the immobilization of defense HLW at the Savannah River Site (Bernadzikowiski et al. 1982). Similar technical evaluations and NEPA processes led to selection of borosilicate glass for the commercial wastes at West Valley, NY and the defense HLW at Hanford.

Table 3.1. Candidate Waste Forms Considered for Immobilization of HLW for Disposal (Bernadzikowiski et al. 1982).

\begin{tabular}{|l|l|}
\hline Borosilicate Glass & High-Silica Glass \\
\hline Phosphate Glass & Clay Ceramic \\
\hline Glass Ceramic & Tailored Ceramic \\
\hline Synroc & Titanate Ion Exchanger \\
\hline Stabilized Calcine & Pelletized Calcine \\
\hline Normal Concrete & Hot-Pressed Concrete \\
\hline FUETAP Concrete & Matrix Forms \\
\hline Coated Sol-Gel Particles & Cermet \\
\hline Disk-Pelletized Coated Particles & \\
\hline
\end{tabular}

Lutze and Ewing (1988), in their compendium on radioactive waste forms, evaluated a similar set of waste forms and concluded that borosilicate glass and Synroc were the most highly developed waste forms available.

In the U.S., the Environmental Protection Agency (EPA) has established vitrification of HLW as the best demonstrated available technology for addressing land disposal restrictions for the Resource Conservation and Recovery Act (RCRA) hazardous metal content of the HLW (40 CFR 268.40).

Internationally, borosilicate glass is used almost exclusively for the immobilization of HLW. The French were the first to vitrify HLW in a borosilicate glass in their AVM facility in Marcoule, France (Amaury 1980; Bonniaud et al. 1975; Bonniaud et al. 1976; Bonniaud et al. 1979; Sombret 1983). Since then, HLW vitrification facilities using borosilicate glass have been constructed and operated in India, Belgium, UK, Japan, Solvakia, and Germany (see Table 3.2). The Russians are vitrifying their HLW in a phosphate glass. Australia is building a facility to process their radioactive wastes into the Synroc waste form.

Over more than 30 years of waste form evaluations for the immobilization of HLW, borosilicate glass has consistently shown to be the preferred waste form for HLW. The vitrification technology is mature and is used almost universally for treatment of commercial and defense HLW streams. It has the flexibility to treat both acidic and caustic waste streams. Borosilicate glass generally scores highest in technical maturity, robustness, and tolerance to feed variations and impurities. Synroc also consistently scores high in waste form evaluations. It has better durability than glass waste forms, is not technically as mature, it has lower tolerance to some feed variations, and it has different processing challenges compared to borosilicate glass, e.g., controlling microstructure and maintaining a durable grain-boundary phase. Synroc was selected as the baseline waste form for Mo-99 target processing waste in Australia (Moricca et al. 2012) and for Idaho calcine HLW (DOE 2009). 
Table 3.2. Glass Waste Forms used Internationally for Immobilization of HLW.

\begin{tabular}{|l|l|l|l|l|l|}
\hline \multicolumn{1}{|c|}{ Plant } & \multicolumn{1}{|c|}{ Location } & Waste & \multicolumn{1}{c|}{ Melter } & \multicolumn{1}{c|}{ Waste Form } & Startup \\
\hline AVM & Marcoule, France & HLW & HWIM & Borosilicate Glass & 1978 \\
\hline WIP & Trombay, India & HLW & HWRM & Borosilicate Glass & 1985 \\
\hline WIP & Tarapur, India & HLW & HWRM & Borosilicate Glass & 1985 \\
\hline Radon & Moscow, Russia & ILW & $\begin{array}{l}\text { LFCM } \\
\text { CCIM }\end{array}$ & $\begin{array}{l}\text { Borosilicate Glass } \\
\text { Borosilicate Glass }\end{array}$ & $\begin{array}{l}1985 \\
1999\end{array}$ \\
\hline Pamela & Mol, Belgium & HLW & LFCM & Borosilicate Glass & 1985 \\
\hline MCC & Mayak, Russia & HLW & LFCM & Alumino Phosphate Glass & 1987 \\
\hline R7 & LaHague, France & HLW & HWIM & $\begin{array}{l}\text { Borosilicate Glass } \\
\text { Borosilicate Glass }\end{array}$ & 1989 \\
\hline WVP & Sellafield, UK & HLW & HWIM & Borosilicate Glass & 1990 \\
\hline T7 & LaHague, France & HLW & HWIM & Borosilicate Glass & 1992 \\
\hline TRP & Tokai, Japan & HLW & LFCM & Borosilicate Glass & 1995 \\
\hline DWPF & Savannah River, U.S. & HLW & LFCM & Borosilicate Glass & 1996 \\
\hline WVDP & West Valley, U.S. & HLW & LFCM & Borosilicate Glass & 1996 \\
\hline VICHR & Bohunice, Slovakia & HLW & HWIM & Borosilicate Glass & 1997 \\
\hline AVS & Tarapur, India & HLW & LFCM & Borosilicate Glass & 2008 \\
\hline UVF & Ulchin, ROK & ILW & CCIM & Borosilicate Glass & 2009 \\
\hline VEK & Karlsruhe, Germany & HLW & LFCM & Borosilicate Glass & 2010 \\
\hline WIP & Kalpakkam, India & HLW & LFCM & Borosilicate Glass & 2012 \\
\hline RRP & Rokkasho, Japan & HLW & LFCM & Borosilicate Glass & TBD \\
\hline WTP & Richland, U.S. & HLW & LFCM & $\begin{array}{l}\text { Borosilicate Glass } \\
\text { Borosilicate Glass }\end{array}$ & TBD \\
\hline
\end{tabular}

\subsubsection{GNEP HLW Waste Form Recommendations}

In the GNEP studies (Gombert et al. 2007 and 2008; AFCF 2007; CFTC 2008) the HLW streams were partitioned into four separate streams using any one of the UREX + family of processes:

- $\mathrm{Cs}, \mathrm{Sr}, \mathrm{Ba}$, and Rb stream (CS/SR) separated from the HLW raffinate using CCD-PEG or FPEX process

- Transition metal fission products (TMFP) from the TRUEX raffinate

- Lanthanide fission products (LNFP) from the TALSPEAK product

- UDS from clarification combined with the soluble Tc from ion-exchange of the uranyl nitrate stream reduced to a metal form (UDS/Tc)

The GNEP baseline waste management approach was to immobilize each of these four streams in separate waste forms.

\subsection{1. $C S / S R$}

Gombert et al. (2007) evaluated aluminosilicate ceramics, glass bonded sodalite, clay-based minerals, a mix of titanates (for $\mathrm{Cs}$ and $\mathrm{Rb}$ ) and niobates (for $\mathrm{Ba}$ and $\mathrm{Sr}$ ), silicate glasses, phosphate glasses, and cermets and vitromets for immobilization of the CS/SR waste stream. The evaluation showed a preference for glass over ceramics primarily due to the respective levels of development and foreseeable problems with powder handling for this particular waste. Potential powder handling problems must be weighed against the off-gas treatment and recycle constraints for the vitrification process. Particular 
preference was later given to a high temperature melting silicate glass with relatively high glass transition temperature $\left(\mathrm{T}_{\mathrm{g}}\right)$ (Ryan et al. 2009).

\subsubsection{TMFP and LNFP}

Gombert et al. (2007) evaluated borosilicate glass, phosphate glass, various mineral forms for individual components, Synroc like titanate ceramics, composites, and metal for immobilization of the TMFP and LNFP waste streams separately or combined. The evaluation showed a preference for borosilicate glass waste form for the combined TMFP and LNFP waste stream. They identified the cold-crucible induction melter (CCIM) as the most suitable technique to process this waste. For the separated individual waste streams it was recommended that the TMFP be combined with UDS/Tc to form an iron based alloy with high performance and reduced overall waste form volume. A high-temperature borosilicate glass was recommended for the LNFP stream and for the combined CS/SR and LNFP stream. A secondary recommendation for the LNFP stream was ceramic waste forms that could be produced in a CCIM.

\subsubsection{UDS/Tc}

Gombert et al. (2007) evaluated iron and zirconium based alloys for immobilization of the aqueous UDS/Tc stream. They also considered vitrification, but, ruled it out because of the difficulty in processing noble metals and Tc in existing waste glass melters. The Fe- $\mathrm{Zr}$ alloy waste form was recommended without a specific composition.

\subsubsection{Combined Waste Stream Trade Study}

After the baseline waste forms study was complete, a trade study was performed to consider if separating aqueous HLW into component streams was a cost effective option (Gombert et al. 2008b and 2009). This study clearly showed that the cost and complexity of separations, waste form fabrication; storage; and disposal for multiple streams far exceeded the cost and complexity of disposing of the HLW in a combined single waste form. Although several cases were considered, three were ultimately highlighted as listed in Table 3.3 (Gombert et al. 2009). Figure 3.1 shows an example of the results from the study. The first plot (a) compares the volumes generated from three example cases where the case 1 has the highest volume and case 2 the lowest. The second plot (b) shows that despite the volume, case 1 costs less and case 2 costs more than the base case. The absolute costs were found to significantly vary with assumptions, but, the ordering was independent of any reasonable assumptions, including the possibility that CS/SR stream may be disposed of in near-surface disposal facility (at orders of magnitude lower cost) after a century of decay storage.

Table 3.3. Summary of Waste Forms for Three Primary Cases Considered by Gombert et al. 2009)

\begin{tabular}{|l|c|c|c|}
\hline Stream/Case & Base & $\mathbf{1}$ (Glass) & 2 (Alloy) \\
\hline CS/SR & High Temp Glass & \multirow{2}{*}{ High Temp Glass } & High Temp Glass \\
\cline { 1 - 1 } LNFP & Low Temp Glass & & Alloy \\
\hline TMFP & Alloy & Alloy & \\
\hline UDS/Tc & \multicolumn{2}{|l}{} &
\end{tabular}




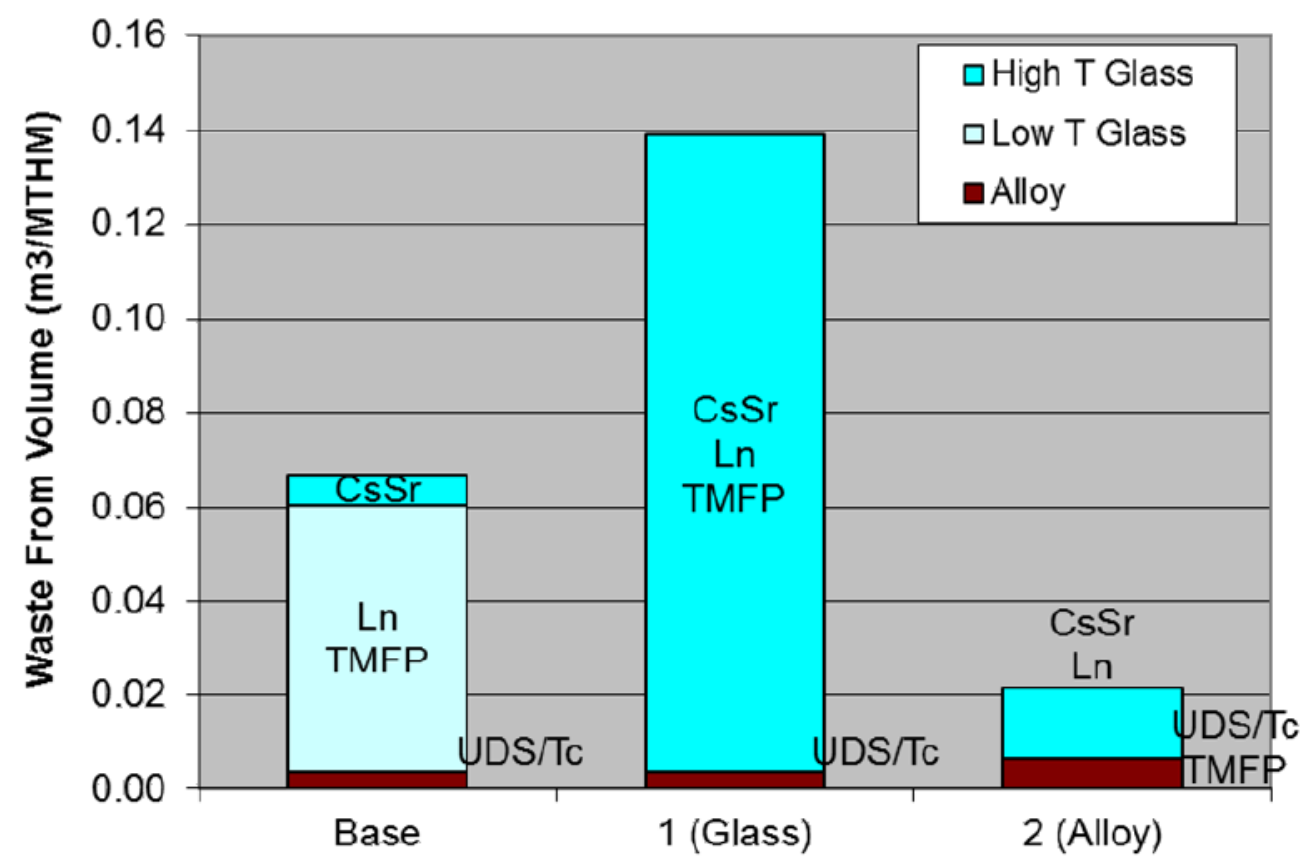

(a)

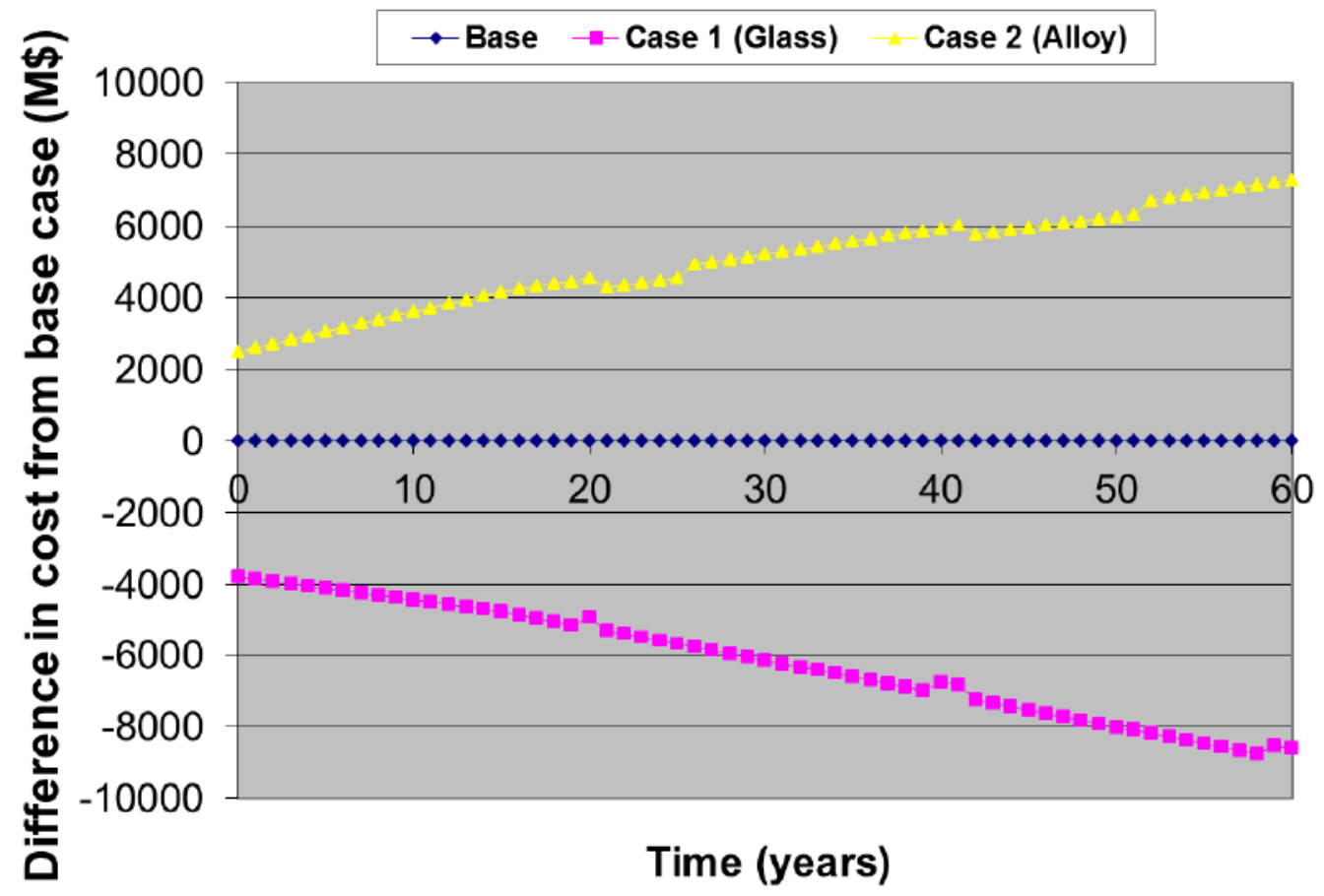

(b)

Figure 3.1. Comparison of Waste Form Volume (a) and Cost (b) for Different Combined Waste Streams (Gombert et al. 2009).

Another case, not shown in the figures, considered combining the UDS/Tc into the HLW glass to generate a single HLW waste form (the current practice in both France and Japan). The cost of this option 
compared to that of case 1 (HLW glass plus UDS/Tc in alloy) depended strongly on assumptions. With the assumption that the HLW glass melter could tolerate up to 3 mass $\%$ noble metal oxides (the current limit for LaHague; Ladirat et al. 2004), the single glass waste form was the lowest cost. Below the 3 mass\% noble metal oxides limit, either case may be more cost effective depending on cost for forming the UDS/Tc alloy, noble metal oxide limit, and HLW disposal costs.

Therefore, the management of aqueous HLW is significantly different in the study compared to the previous studies. The HLW streams are assumed to be combined and immobilized in a single waste form.

\subsection{Borosilicate Glass}

Silicate glass is solid formed from a melt usually consisting of $\mathrm{Na}_{2} \mathrm{O}, \mathrm{CaO}, \mathrm{Al}_{2} \mathrm{O}_{3}, \mathrm{~B}_{2} \mathrm{O}_{3}$, and $\mathrm{SiO}_{2}$ as the main oxide components. These glass systems are modified with the addition of the waste solids. Glass is an amorphous solid in which there is no long-range ordering of the atoms. This random nature in the glass structure allows many elements to fit into the overall glass structure without the formation of crystals. However, glass is thermodynamically unstable with respect to more crystalline phases. Thus, when placed in water or heated dry to temperatures above the glass transition, it alters to crystalline phases - alteration in the former and devitrification in the latter case. Both of these phenomena have been well studied. In the case of aqueous dissolution, the mechanisms are well understood although rates of each reaction under different conditions are still uncertain (Vienna et al. 2013). The process of devitrification is well understood although conditions under which it occurs are highly dependent on melt composition.

The unit operations for the production of glass are well defined from many years of experience. In the U.S., the waste is usually fed directly to the melter as an aqueous solution. This can be mixed with frit, a preformed glass of defined composition, as is done at the Defense Waste Processing Facility (DWPF) at the Savannah River Site (Jantzen 1988) or as a number of chemical additives, the ratios of which are determined by the composition of the waste, as was done at the West Valley Site (Chick et al. 1984; Chick et al. 1986). In France and England, the waste is calcined with additives before being added to the melter (Amaury 1980; Bonniaud et al. 1975; Bonniaud et al. 1976; Bonniaud et al. 1979; Sombret 1983). The melters usually operate at temperatures between 1000 and $1200{ }^{\circ} \mathrm{C}$. However, to achieve higher glass transition temperatures or to solubilize larger fractions of troublesome waste components higher temperature melting may be needed (e.g., 1300 to $1600^{\circ} \mathrm{C}$ ). The melt is poured directly from the melter into a steel canister. Because of the large amount of water that is evaporated and potential volatility of elements like $\mathrm{Cs}$ and $\mathrm{Tc}$, a large part of the facility footprint is devoted to off-gas processing. Semivolatile components (e.g., Tc, Cs) captured in the initial off-gas scrub are recycled back to the melter.

Borosilicate glasses have been developed for a host of different HLW compositions and processing methods. Examples of glasses for HLW produced from PUREX processing of UOX LWR fuels in France and Japan are given in Table 3.4 (Gin and Mestre 2001, Maeda et al. 2001). These compositions are similar and contain between 18 and 20 mass\% fission product oxides, although the waste loading will vary with decay heat. The heat limits for canistered glass depend on storage facility design and range from $2.5 \mathrm{~kW} / \mathrm{can}$ at La Hague to $1.3 \mathrm{~kW} / \mathrm{can}$ at Tokai (with Sellafield and Rokkasho falling within the range). It can be safely assumed that a similar glass can be fabricated from HLW raffinate produced from the compositions given in Table 1.5 . 
Table 3.4. Example HLW Compositions

\begin{tabular}{|c|c|c|}
\hline Oxide & R7/T7 & P0798 \\
\hline $\mathbf{A l}_{2} \mathbf{O}_{3}$ & 4.91 & 5.00 \\
\hline $\mathrm{B}_{2} \mathrm{O}_{3}$ & 14.02 & 14.20 \\
\hline $\mathrm{BaO}$ & 0.60 & 0.49 \\
\hline $\mathrm{CaO}$ & 4.04 & 3.00 \\
\hline $\mathrm{Cr}_{2} \mathrm{O}_{3}$ & 0.51 & 0.10 \\
\hline $\mathrm{Cs}_{2} \mathrm{O}$ & 1.42 & 0.75 \\
\hline $\mathrm{Fe}_{2} \mathrm{O}_{3}$ & 2.91 & 2.04 \\
\hline $\mathbf{L i}_{2} \mathbf{O}$ & 1.98 & 3.00 \\
\hline $\mathrm{MnO}_{2}$ & 0.72 & 0.37 \\
\hline $\mathrm{MoO}_{3}$ & 1.70 & 1.45 \\
\hline $\mathrm{Na}_{2} \mathrm{O}$ & 9.86 & 10.00 \\
\hline $\mathrm{NiO}$ & 0.74 & 0.23 \\
\hline $\mathrm{RuO}_{2}$ & 0.96 & 0.74 \\
\hline $\mathrm{SiO}_{2}$ & 45.48 & 46.60 \\
\hline $\mathrm{ZnO}$ & 2.50 & 3.00 \\
\hline $\mathrm{ZrO}_{2}$ & 2.65 & 1.46 \\
\hline$[\mathrm{Ln}, \mathrm{An}]_{2} \mathrm{O}_{3}$ & 4.91 & 6.10 \\
\hline Minors $^{(1)}$ & 0.09 & 1.46 \\
\hline \multicolumn{3}{|c|}{$\begin{array}{l}\text { (1) Minors is the sum off all components } \\
\text { comprising less than } 0.35 \text { mass } \% \text { in both } \\
\text { nominal glass compositions. }\end{array}$} \\
\hline
\end{tabular}

\subsection{Titanate-Based Ceramics}

In general, Synroc (i.e., synthetic rock) (Ringwood et al. 1980; Ringwood et al. 1981) is a synthetic crystalline ceramic comprised of geochemically stable titanate minerals, which have immobilized uranium, thorium, and other natural radioactive isotopes in the environment for millions of years. These minerals and their man-made analogs are capable of incorporating into their crystal structures nearly all of the elements present in HLW, including the fission products and actinides that need to be immobilized. Synroc can take various forms depending on its specific use and can be tailored to immobilize particular components in the HLW. As such, Synroc formulations A-F have already been developed and proven durable for a variety of radioactive waste compositions, Table 3.5.

The main titanate minerals in Synroc have traditionally been Ba-hollandite ( $\left.\mathrm{BaAl}_{2} \mathrm{Ti}_{6} \mathrm{O}_{16}\right)$, zirconolite $\left(\mathrm{CaZrTi}_{2} \mathrm{O}_{7}\right)$, and perovskite $\left(\mathrm{CaTiO}_{3}\right)$ (Lumpkin et al. 1995). Zirconolite and perovskite are the major immobilization hosts for actinides such as Pu and the rare earth elements (REE) Sc, Y, and the lanthanides; whereas perovskite is the principal immobilization host for Sr. Ba-hollandite is principally used to immobilize $\mathrm{Cs}, \mathrm{Sr}, \mathrm{K}, \mathrm{Rb}$, and $\mathrm{Ba}$. Depending on the waste composition, other minor synthetic mineral phases can be included, such as other forms of hollandite, magnetoplumbite (also for $\mathrm{Sr}$ ), pyrochlore, and rutile $\left(\mathrm{TiO}_{2}\right)$.

The principal advantage of the titanate-based ceramics is that the waste ions are incorporated (HLW loadings vary from 10-35 mass\%) in durable titanate mineral phases, which are considerably less soluble in water relative to the vitreous silicates and phosphates - especially at high temperatures and pressures. High temperatures and pressures may be of concern because of the natural intrusive water that can enter the waste storage/disposal area over long time periods. Such scenarios indicate that that the decay heat of the waste form builds natural convective flow currents for the intrusive water. This heated water, after leaching from the given waste form, flows away, cools, precipitates the leached material and then is recirculated back to the form to potentially leach some more. Testing indicates that Synroc phases, like 
their natural analogues, are resistant to these sorts of hydrothermal leaching conditions and many current standard durability tests do not take into account these thermal conditions. The same testing has also indicated that other waste forms (including glass) are not as durable under these hydrothermal conditions (e.g., Lutze et al. 1990).

Ceramic waste forms have been found to be susceptible to radiation damage - especially alpha-induced radiation damage. However, the current separations flowsheet processes that include removal of most actinide species should minimize this potential deleterious effect.

Table 3.5. Synroc Family of Compositions.

\begin{tabular}{|c|c|c|c|}
\hline Synroc Form & Phase Assemblage (mass\%) & Loading mass\% & Fabrication Process \\
\hline Synroc-A & $\begin{array}{l}40 \% \text { Ba-feldspar, } 30 \% \text { hollandite, } \\
20 \% \text { perovskite, } 10 \% \text { zirconia, } \\
\text { kalsilite, leucite or both }\end{array}$ & $10 \% \mathrm{HLW}$ & $\begin{array}{l}\text { Melting \& crystallizing at } \\
1330^{\circ} \mathrm{C}\end{array}$ \\
\hline Synroc-B & $\begin{array}{l}40 \% \text { hollandite, } 35 \% \text { zirconolite, } \\
25 \% \text { perovskite }\end{array}$ & N/A & $\begin{array}{l}\text { Hot pressing at } \\
1200-1400^{\circ} \mathrm{C}\end{array}$ \\
\hline Synroc-C & $\begin{array}{l}33 \% \text { hollandite, } 28 \% \text { zirconolite, } \\
19 \% \text { perovskite, } 15 \% \text { rutile, } \\
5 \% \text { noble metal alloy }\end{array}$ & $20 \% \mathrm{HLW}$ & Hot pressing at $1150^{\circ} \mathrm{C}$ \\
\hline Synroc-D & $\begin{array}{l}46 \% \text { spinel solid solution, } \\
19 \% \text { zirconolite, } 17 \% \text { nepheline, } \\
15 \% \text { perovskite, } 3 \% \text { hollandite }\end{array}$ & $63 \%$ HLW & $\begin{array}{l}\text { Hot pressing at } \\
1050-1100^{\circ} \mathrm{C}\end{array}$ \\
\hline Synroc-E & $\begin{array}{l}79 \% \text { rutile, } 7 \% \text { zirconolite, } \\
7 \% \text { perovskite, } 5 \% \text { hollandite, } \\
2 \% \text { pyrochlore }\end{array}$ & $7 \% \mathrm{HLW}$ & Hot pressing at $1300^{\circ} \mathrm{C}$ \\
\hline Synroc-F & $\begin{array}{l}90 \% \text { pyrochlore, } 5 \% \text { hollandite, } \\
5 \% \text { rutile }\end{array}$ & $50 \%$ U-rich HLW & Hot pressing at $1250^{\circ} \mathrm{C}$ \\
\hline Synroc-FA & $\begin{array}{l}89 \% \text { pyrochlore, } 8 \% \text { perovskite, } \\
3 \% \text { uraninite }\end{array}$ & $50 \%$ U-rich HLW & $\begin{array}{l}\text { Cold press and sintering at } \\
1250-1450^{\circ} \mathrm{C}\end{array}$ \\
\hline
\end{tabular}

As noted, ceramic waste forms offer specific advantages over glass waste forms due to the inherent thermodynamic stability of crystalline materials that can translate to improved waste form stability and long-term performance. However, bulk ceramic processing in radioactive environments can be complex and has limited the widespread use of ceramic forms for waste immobilization. The facile preparation of ceramic materials through melt and solidification processes where the solidification process resulted in a crystalline material has been demonstrated using the Cold Crucible Induction Melter (CCIM) technology (Stefanovsky et al. 2007, Demine et al. 2001, and Leturcq et al. 2001). In this manner, the bulk processing of ceramic forms would be simplified, and the advantages of a crystalline ceramic waste form can be combined with existing processing facilities and knowledge currently implemented in waste vitrification processes.

As part of the FCRD program, melt processing has been investigated as an alternative to solid-state sintering methods to produce ceramic waste forms from wastes resulting from potential advanced fuel separations processes. The assemblages of several titanate phases crystallized from the melt have been successfully demonstrated to incorporate radioactive waste elements, and the multiphase nature of these materials allows them to accommodate variation in the waste composition (Amoroso et al. 2014a). The most recent studies have shown that $\mathrm{Cr}$ additions promote the formation and stability of a Cs containing hollandite phase and preclude formation of a non-durable cesium molybdate phase (Amoroso et al. 2014a,b). Additionally, control of the reduction-oxidation (Redox) conditions further suppressed undesirable Cs-Mo coupling. Finally, additions of $\mathrm{Al}$ and $\mathrm{Fe}$ could be used to reduce the melting temperature to facilitate melter processing. Near term efforts will be focused on performing scaled melter tests to demonstrate process feasibility for the ceramic waste form melt-crystallization process. 
The waste form developed for a variant of the HLW composition assumed in this study found waste loadings of 24 mass\% and bulk densities (Archimedes) ranging from 4500 to $4800 \mathrm{~kg} / \mathrm{m}^{3}$ (Braase and May 2014). Assuming a density of $4500 \mathrm{~kg} / \mathrm{m}^{3}$, roughly $0.05 \mathrm{~m}^{3} / \mathrm{tU}$ would be produced from the reference waste stream; largely independent of cooling time.

\subsection{Phosphate Glass}

Phosphate glasses are amorphous solid materials with the waste chemically bound within the solid structure much like borosilicate glasses. However, in the case of phosphate glasses the network is primarily composed of $\mathrm{PO}_{4}$ tetrahedra instead of $\mathrm{SiO}_{4}$ tetrahedra. Two general families of phosphate glasses have been investigated for vitrifying a wide range of different radioactive wastes. In research supported by DOE, more than 500 iron phosphate glass waste form compositions have been studied over a $\sim 15$ years, by Day and colleagues at the Missouri University of Science and Technology (see Day and Ray 2013 for a summary of that work). Sodium alumino-phosphate glasses have been produced in Russia since 1987 (Bradley and Payson 1997; Romanovski 2003, Borisov et al. 1999) to vitrify HLW, producing more than 5,720 metric tons of glass over the time from 1987 to 2010 .

These glasses are primarily composed of $\mathrm{P}_{2} \mathrm{O}_{5}, \mathrm{Al}_{2} \mathrm{O}_{3}, \mathrm{Fe}_{2} \mathrm{O}_{3} / \mathrm{FeO}$, and $\mathrm{Na}_{2} \mathrm{O}$. The properties of phosphate glasses and melts tend to vary smoothly with concentrations of chemical additives. For some properties, there is a transition in property-composition relationships at an oxygen-to phosphorous atomic ratio, $[\mathrm{O}]:[\mathrm{P}]$, of approximately 3.5. Phosphate glasses have a number of advantages over silicate-based glasses. Primary among them are the relatively high solubility of chemical components that tend to be sparsely soluble in silicate melts (e.g., Cr, P, S, Mo) and relatively low melting temperatures. However, they tend to be less chemically durable, more susceptible to devitrification, and more corrosive to melter materials.

An evaluation of phosphate based glasses for GNEP found that they had significant advantages for flowsheets resulting in high sulfate wastes or high molybdate wastes as phosphate glass can contain up to roughly 4 mass $\%$ of either $\mathrm{SO}_{3}$ or $\mathrm{MoO}_{3}$ compared to roughly 1 and 2.5 mass $\%$, respectively, for standard borosilicate glasses (Ryan et al. 2009). However, wastes whose loadings in borosilicate glass are limited by either heat or noble metals $(\mathrm{Pd}, \mathrm{Ru}, \mathrm{Rh})$ would not be appropriate for phosphate glasses. For the nominal waste composition supplied in Table 1.5, the loading would be limited by noble metals and heat (for $5 \mathrm{y}$ cooled waste), giving no advantage to the phosphate glass over borosilicate glasses.

\subsection{Metal Waste Forms}

Metal waste forms were developed as part of the GNEP project for immobilization of hulls, UDS, soluble $\mathrm{Tc}$, and/or transition metal fission product stream from aqueous processing operations. Initially, the metal compositions were based on those developed for hulls and UDS from electrochemical processing of EBRII fuels: SS-15\% Zr (see Section 6 for a detailed description of EBR-II metal waste form). Several representative alloy waste form materials were made by melting simulated fuel wastes with Type $316 \mathrm{~L}$ stainless steel and tested to demonstrate fuel-waste loadings up to about $50 \%$ and the capacity to encapsulate significant amounts of oxide with the alloys. Later, an epsilon metal waste form was developed to represent direct processing of the fuel wastes without zirconium or added steel.

\subsubsection{UDS Composition Variation}

The undissolved solids (UDS) remaining after dissolution and clarification are primarily composed of three phases: 1) epsilon metal particles formed during irradiation, 2) phases precipitated from solution in 
the dissolver or clarifier, and 3) chips of hulls generated during shearing process. The epsilon $(\varepsilon)$ phase or 5-metal particles, form as primarily submicron alloy particles in UOX fuels during irradiation and remain when fuel is dissolved in concentrated $\mathrm{HNO}_{3}$ (Kleykamp and Pejsa 1984). The main components of the 5-metal particles are $\mathrm{Mo}, \mathrm{Ru}, \mathrm{Rh}, \mathrm{Tc}$, and Pd. Tellurium has also been found in $\varepsilon$-metal phases when fuel was dissolved under non-oxidizing conditions (Cui et al. 2004). Small amounts of Ag, Cd, Sn, and Sb may also be present in the alloy, but these elements are in only trace concentrations in the fuel and are difficult to detect. According to Kleykamp (1985), the composition of the 5-metal particle: “...varies considerably and depends on the fission yield, the initial $\mathrm{O} /(\mathrm{U}+\mathrm{Pu})$-ratio of the fuel, i.e., the oxygen potential, the temperature gradients in the pin, and the burn-up. As the oxygen potential of the $\mathrm{Mo} / \mathrm{MoO}_{2}$ equilibrium is similar to slightly hypostoichiometric uranium-plutonium oxide fuel, the Mo concentration in the alloys decreases continuously by oxidation of this element during irradiation due to an increase of the oxygen potential of the FBR fuel with burn-up." The relative amounts of Rh, Tc, and Pd are expected to remain fairly consistent from fuel-to-fuel.

Depending on the chemistry of the dissolver and clarifier processes, varying amounts of hydrated zirconium molybdates can precipitate and contain other elements such as $\mathrm{U}, \mathrm{Pu}, \mathrm{Ba}$, rare earths, $\mathrm{Sr}, \mathrm{Cs}$, and Te. Rao et al. (1990) identified the primary precipitates as a mixture of $\mathrm{ZrMo}_{2} \mathrm{O}_{7}(\mathrm{OH})_{2} \cdot 2 \mathrm{H}_{2} \mathrm{O}$, $\mathrm{UO}_{2} \mathrm{Mo}_{2} \mathrm{O}_{7} \cdot 1.3 \mathrm{H}_{2} \mathrm{O}, \mathrm{Pu}\left(\mathrm{MoO}_{4}\right)_{2} \cdot \mathrm{H}_{2} \mathrm{O}$ and a range of non-crystalline molybdates. Various other oxides have been observed in spent fuel, including $\mathrm{Ba}(\mathrm{U}, \mathrm{Zr}, \mathrm{Mo}) \mathrm{O}_{3},(\mathrm{Ba}, \mathrm{Cs}, \mathrm{Sr}) \mathrm{MoO}_{3},(\mathrm{Ba} \mathrm{Sr}) \mathrm{TeO}_{3}$, and $\mathrm{Pu}_{2} \mathrm{O}_{2} \mathrm{Te}$ have been identified in UDS. Lausch et al. (1994) found that 0.02 and $1.5 \%$ of the U and Pu from the original fuel partitioned to the UDS from UOX fuel dissolved in $13 \underline{\mathrm{M}} \mathrm{HNO}_{3}$. Silver iodide has also been identified in the UDS (Sakurai et al. 1991, 1992, 1997; and Herrmann et al. 1997). Whether this is a precipitation product or formed in the fuel is unknown.

Many researchers (e.g., Adachi et al. 1990, Lausch et al. 1994, Kleykamp 1990, Fortner 2007.) have detected chips of zirconium cladding and stainless steel components in the UDS. The amount of steel and cladding found in UDS will depend on shear operations.

Adachi et al. (1990) dissolved a PWR fuel (31.4 GWd/tU) in $4 \underline{\mathrm{M}} \mathrm{HNO}_{3}$ at about $100{ }^{\circ} \mathrm{C}$ under a stream of He. Their analysis of some of the undissolved solids showed that about 70 mass\% of the UDS was composed of Mo, Tc, Ru, Rh, and Pd, with the remainder being chips of cladding, etc. The solids were analyzed with XRD and SEM with associated electron probe microanalysis. The mean particle size (as measured with laser dispersion) increased from $68.4 \mathrm{~nm}$ at $2.5 \mathrm{~h}$ after dissolution to $117 \mathrm{~nm}$ at $3.5 \mathrm{~h}$ after dissolution due to aggregation of the particles. Samples of the UDS from dissolutions of from fuel rod segments that had experienced different burn-ups were dissolved for chemical analysis (Adachi et al. 1990). Those results are summarized to provide insight into the variance in the contents of Tc and other components with fuel burn-up. The calculated burn-up increases from $8.4 \mathrm{GWd} / \mathrm{tU}$ for Sample 1 at or near the end, to $17.6 \mathrm{GWd} / \mathrm{tU}$ for Samples 2, 3, and 4, to $31.4 \mathrm{GWd} / \mathrm{t}$ for Samples 5, 6, 7, and 8, to $36.1 \mathrm{GWd} / \mathrm{tU}$ for Samples 9 and 10. The amounts of UDS recovered from the dissolved segments increased with the burn-up, from about 0.01 mass $\%$ at a burn-up of $8.4 \mathrm{GWd} / \mathrm{tU}$ to about $0.4 \mathrm{mass} \%$ at a burn-up of $36.1 \mathrm{GWd} / \mathrm{tU}$. The compositions of the dissolved UDS samples are compared in Table 3.2. The concentrations of the components that comprise the insoluble 5-metal particles $\mathrm{Mo}, \mathrm{Tc}, \mathrm{Ru}, \mathrm{Rh}$, and $\mathrm{Pd}$ ) are the most consistent between segments, with the average contents being $19 \% \mathrm{Mo}, 50 \% \mathrm{Ru}, 8.6 \%$ $\mathrm{Rh}, 7.0 \% \mathrm{Pd}$, and $2.6 \% \mathrm{Tc}$. The vertical lines in Table 3.2 group the samples according to burn-up and the numbers on the graph give the average burn-up, in $\mathrm{GWd} / \mathrm{tU}$, for each group of segments. Neglecting the results for Sample 1, which was taken from the end of the rod, the relative amounts of each element are only slightly affected by the burn-up: the relative amounts of $\mathrm{Ru}$ and Pd increase with burn-up (consistent with the results from the ORIGEN2 code calculation (Croff 1983)), as does Mo to smaller extent (contrary to the ORIGEN2 calculation results), whereas the relative amounts of Tc and Rh decrease with burn-up (consistent with the ORIGEN2 calculation results). The fractions of the 5 noble metals initially in the fuel (from ORIGEN2 calculations) that were found in the UDS from sample 8 (34.1 $\mathrm{GWd} / \mathrm{tU}$ ) were $15.5 \% \mathrm{Mo}, 13.9 \% \mathrm{Pd}, 39.9 \% \mathrm{Rh}, 58.2 \% \mathrm{Ru}$, and $2.9 \% \mathrm{Tc}$ (Adachi et al. 1990). 


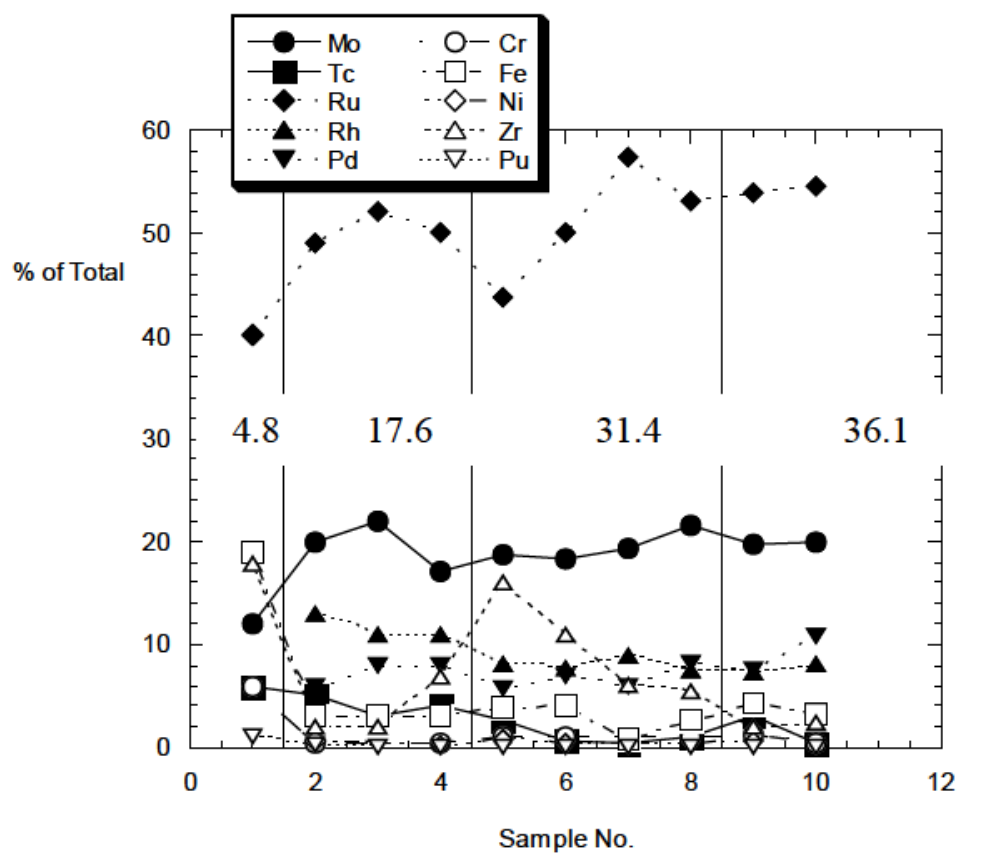

Figure 3.2. The UDS Compositions of Various Segments of Irradiated Nuclear Fuels, as percentage of total mass (Adachi et al. 1990).

Residues from LWR fuel that was dissolved in hot $\mathrm{HNO}_{3}$ were examined with surface analytical and chemical methods (Lausch et al. 1994). The UDS included an abundance of sub-micrometer-size fines and larger particles (up to $30 \mu \mathrm{m}$ ). Analysis revealed two phases: "a metallic phase mainly composed of $\mathrm{Mo}, \mathrm{Ru}$, and $\mathrm{Rh}$, and an oxidic phase with the main components $\mathrm{Zr}$ and $\mathrm{Mo}$, but containing also significant amounts of Pu" (Lausch et al. 1994). In addition to Pu, the oxide phase contained small amounts of $\mathrm{Ru}, \mathrm{Rh}, \mathrm{Tc}$, and Pd (these could be entrained 5-metal particles). The authors also mentioned the presence of large inclusions containing $\mathrm{Fe}, \mathrm{Cr}, \mathrm{Ni}$, and $\mathrm{Zr}$. The chemical composition from one sampling of the UDS fine material was reported: $48.3 \% \mathrm{Mo}, 18.8 \% \mathrm{Ru}, 3.2 \% \mathrm{Tc}, 3.0 \% \mathrm{Rh}, 2.6 \% \mathrm{Pd}$, $14.1 \% \mathrm{Zr}, 4.1 \% \mathrm{Pu}, 3.5 \% \mathrm{Te}$, and $2.4 \% \mathrm{U}$ (on a metal basis). The amounts of $\mathrm{Pu}$ and $\mathrm{U}$ measured in the dissolved UDS are consistent with the solids analyses. The fractions of the initial inventories in the fuel that remained in the undissolved residue were not reported.

Kleykamp (1988) suggested that the dissolution rate of the 5 -metal phase in $7 \underline{\mathrm{M} \mathrm{HNO}} \mathrm{HN}_{3}$ at $110{ }^{\circ} \mathrm{C}$ was in the range of 0.28 to $2.8 \mathrm{mg} /\left(\mathrm{m}^{2} \cdot \mathrm{s}\right)$ [0.01 to $\left.0.1 \mathrm{mg} /\left(\mathrm{cm}^{2} \mathrm{~h}\right)\right]$, and that at this rate, 55 to $550 \mathrm{~h}$ would have been required to completely dissolve a $10-\mu \mathrm{m}$ size particle. The size of the particles in the fuel depends on fuel density, heating rate, and burn-up. Dissolution for $8 \mathrm{~h}$ under these conditions would allow for the complete dissolution of particles $1.5 \mu \mathrm{m}$ and smaller.

Demonstrations of the fuel dissolution step of the aqueous GNEP process have been conducted wherein unclad BWR fuel $(30.1 \mathrm{GWd} / \mathrm{tU})$ was dissolved at elevated temperatures (about $\left.150{ }^{\circ} \mathrm{C}\right)$ in $5.8 \underline{\mathrm{M}} \mathrm{HNO}_{3}$ (Bakel et al. 2006), at about $100{ }^{\circ} \mathrm{C}$ in about 6.4 $\underline{\mathrm{M}} \mathrm{HNO}_{3}$ with added $2 \underline{\mathrm{M}} \mathrm{HF}$ (Pereira et al. 2006), and $600{ }^{\circ} \mathrm{C}$ TPT followed by dissolution between 90 and $95{ }^{\circ} \mathrm{C}$ for $8 \mathrm{~h}$ in $7.67 \mathrm{M} \mathrm{HNO}_{3}$ (Benker et al. 2008). An important difference in the UDS compositions for fuels dissolved with and without added HF is expected to be the amount of $\mathrm{ZrMO}_{4}$ that forms. ${ }^{\mathrm{f}}$ If a non-negligible amount of TRU is retained in the UDS, it may need to be recovered prior to processing the UDS for disposal.

f The use of $\mathrm{HF}$ in the dissolution step is discouraged to avoid complexing $\mathrm{Pu}(\mathrm{IV})$, which lowers the extraction efficiency in subsequent separation operations plus HF will increase materials challenges in plant design. 
By comparing the measured composition of the dissolver solution with the composition of ATM-105 BWR fuel that was calculated with the ORIGEN2 code, Bakel et al. (2006) concluded that the majority of the Mo (84.9\%), $\mathrm{Ag}(61.4 \%)$, and Te (52.1\%), and much of the Pu (19.8\%), Sn (10.9\%), Tc (6.2\%), Cd (2.8\%), Ba (1.7\%), Y (1.6\%), and $\mathrm{Ru}(1.2 \%)$ from the fuel remained in the residue. Trace fractions of the available $\mathrm{Sr}(0.9 \%), \mathrm{Pd}(0.6 \%), \mathrm{Zr}(0.6 \%), \mathrm{Cs}(0.5 \%), \mathrm{Rh}(0.5 \%), \mathrm{Rb}(0.3 \%)$, and $\mathrm{Np}(0.2 \%)$ were also expected to be present in the residue. Chemical dissolution and analysis of a portion of the undissolved solids gave a composition (normalized to $100 \%$ ) of about $40 \% \mathrm{Mo}, 27 \% \mathrm{Pu}, 25 \% \mathrm{Zr}, 2.8 \% \mathrm{U}, 2.5 \% \mathrm{Te}$, $0.39 \% \mathrm{Ru}, 0.31 \% \mathrm{Tc}, 0.04 \% \mathrm{Rh}$, and $0.07 \% \mathrm{Pd}$. Although the inefficient dissolution of Pu resulting from this method was unacceptable, the relative amounts of $\mathrm{Ru}, \mathrm{Rh}, \mathrm{Pd}$, and $\mathrm{Tc}$ were not expected to be significantly affected by the dissolution procedure. Small amounts of $\mathrm{Fe}, \mathrm{Cr}$, and $\mathrm{Ni}$ were present in the dissolver solution from the corrosion of the steel dissolver vessel. These metals are expected to remain in the dissolver solution and be recovered in the TRUEX raffinate waste stream.

Another portion of the same ATM-105 BWR fuel was dissolved following a modified procedure using a slightly higher nitric acid concentration with a small amount of $2 \underline{\mathrm{M}} \mathrm{HF}$ to promote the dissolution of $\mathrm{Pu}$ (Pereira et al. 2006). The composition of the UDS was estimated from the difference between the composition of the fuel calculated with ORIGIN2 and the analyzed dissolver solution. Of the more abundant radionuclides in the fuel, the majority of the Mo (93\%), and much of the Ru (47\%), Rh (39\%), $\mathrm{Zr}(33 \%), \mathrm{Pd}(29 \%), \mathrm{Tc}(24 \%), \mathrm{Te}(22 \%)$, and $\mathrm{Rb}(21 \%)$ calculated to have been in the fuel were in the undissolved residue. It was determined that about $90 \%$ of the available $\mathrm{Pu}$ was in the dissolver solution, with the balance presumed to be in the UDS. Of the less abundant nuclides, significant fractions of the available $\mathrm{Se}(54 \%), \mathrm{Ag}(45 \%)$, and $\mathrm{Cd}(26 \%)$ were present in the undissolved residue, based on analysis of the dissolver solution.

Table 3.6. Retention of Elements of Interest in UDS, as a Percent of Inventory

\begin{tabular}{|c|c|c|c|c|c|}
\hline Study & This Study & Bakel et al. 2006 & $\begin{array}{c}\text { Pereira et al. } \\
\mathbf{2 0 0 6}\end{array}$ & $\begin{array}{c}\text { Adachi et al. } \\
\mathbf{1 9 9 0}\end{array}$ & $\begin{array}{c}\text { Benker et al. } \\
\mathbf{2 0 0 8}\end{array}$ \\
\hline $\begin{array}{c}\text { Dissolution } \\
\text { conditions }\end{array}$ & $\begin{array}{l}7.32 \mathrm{M} \mathrm{HNO}_{3} \\
\text { at } 100^{\circ} \mathrm{C}\end{array}$ & $\begin{array}{c}5.8 \mathrm{M} \mathrm{HNO}_{3} \\
8 \mathrm{hr} \text { at } 150{ }^{\circ} \mathrm{C}\end{array}$ & $\begin{array}{c}6.4 \mathrm{M} \mathrm{HNO}_{3}+2 \\
\mathrm{M} \mathrm{HF} 6.5 \mathrm{hr} \text { at } \\
100{ }^{\circ} \mathrm{C}\end{array}$ & $\begin{array}{c}4 \mathrm{M} \mathrm{HNO}_{3} \\
\text { at } 100{ }^{\circ} \mathrm{C}\end{array}$ & $\begin{array}{c}600^{\circ} \mathrm{C}_{\text {volox }} \\
7.67 \mathrm{M} \mathrm{HNO}_{3} \\
8 \mathrm{hr} \text { at } \\
90-95^{\circ} \mathrm{C}\end{array}$ \\
\hline $\mathbf{A g}$ & 1 & $\mathrm{NR}^{*}$ & $\mathrm{NR}$ & $\mathrm{NR}$ & $\mathrm{NR}$ \\
\hline $\mathbf{I}$ & 17 & $\mathrm{NR}$ & $\mathrm{NR}$ & $\mathrm{NR}$ & $\mathrm{NR}$ \\
\hline $\mathbf{M o}$ & 50 & 86 & 93 & 15.5 & 20 \\
\hline $\mathbf{P d}$ & 99 & 18 & 29 & 13.9 & 99 \\
\hline $\mathbf{P u}$ & 0.02 & 18 & 10 & $0.005-0.02$ & $\mathrm{NR}$ \\
\hline $\mathbf{R h}$ & 99 & 1 & 39 & 39.9 & 38 \\
\hline $\mathbf{R u}$ & 50 & 1 & 47 & 58.2 & 50 \\
\hline $\mathbf{T c}$ & 50 & 3 & 24 & 2.9 & 50 \\
\hline $\mathbf{T e}$ & 50 & $\mathrm{NR}$ & $\mathrm{NR}$ & $\mathrm{NR}$ & $\mathrm{NR}$ \\
\hline $\mathbf{Z r}$ & 5 & 84 & 33 & $\mathrm{NR}$ & 5 \\
\hline $\mathbf{U}$ & 0.055 & $\mathrm{NR}$ & $\mathrm{NR}$ & $\mathrm{NR}$ & $\mathrm{NR}$ \\
\hline${ }^{*} \mathrm{NR}=\mathrm{not}$ reported & \multicolumn{5}{l}{} \\
\hline
\end{tabular}

The results of UDS analyses by Adachi et al. (1990), Bakel et al. (2006), Pereira et al. (2006), and Benker et al. (2008) are summarized in Table 3.6 as a percentage of the fuel contents. The estimated percentages used in this study are given for comparison. The values in Table 3.6 are meant only to provide a qualitative sense of the distributions and show the ranges resulting from similar dissolution procedures. The results for all elements vary greatly between the analyses. The large differences in the $\mathrm{Mo}$ and $\mathrm{Zr}$ contents in the studies are suspected to reflect different extents of zirconium molybdate precipitation 
under the dissolution and filtration procedures and different amounts of cladding chips. The differences in the results for $\mathrm{Ru}$ and $\mathrm{Rh}$ are not understood, but may be related to the extents to which the 5-metal particles were dissolved. Their size distributions in the fuels and the dissolution times are both expected to affect how efficiently the 5-metal particles are dissolved. Perhaps fortuitously, the dispositions of Tc and Pd are very similar in the Adachi et al. (1990) and Bakel et al. (2006) studies.

\subsubsection{Soluble Tc Reduction}

In the aqueous process, roughly half of the Tc is expected to dissolve - the balance remains in the UDS as a component of the 5-metal particles. The chemistry of the dissolver solution (a nitric acid solution) is such that all dissolved $\mathrm{Tc}$ should be oxidized to $\mathrm{Tc}^{7+}$ as pertechnetate ions $\left(\mathrm{TcO}_{4}{ }^{7}\right)$ or $\mathrm{Tc}_{2} \mathrm{O}_{7}$. The vapor pressure of $\mathrm{Tc}_{2} \mathrm{O}_{7}$ is only about $0.01 \mathrm{~Pa}$ at $100{ }^{\circ} \mathrm{C}$, which is near the dissolver temperatures that have been used in process demonstrations. At this temperature and chemistry, a small amount of Tc could volatilize as $\mathrm{Tc}_{2} \mathrm{O}_{7}$ during fuel dissolution. $\mathrm{Tc}$ as the pertechnetate ion can be recovered in the raffinate with the majority of fission products, with $\mathrm{U}$, or as a separate product, but its behavior is directly dependent on the presence or absence of the other species. Both $\mathrm{Np}$ and $\mathrm{Tc}$ are affected by the stripping reagent used for $\mathrm{Pu}$. If this is a pure reductant such as U(IV), the Np will follow the bulk $\mathrm{U}$ and the Tc will follow the Pu. However, if a reduction/complexation reagent such as acetohydroxamic acid (AHA) is used, the reverse behavior is observed, with $\mathrm{Np}$ following the $\mathrm{Pu}$ and the Tc following the bulk $\mathrm{U}$. In the current aqueous processing flowsheet, the $\mathrm{Tc}$ is partitioned to the $\mathrm{U}$ stream in the co-decontamination process (Section 1.1.2). After the initial $\mathrm{U}, \mathrm{Pu}$, and $\mathrm{Np}$ extraction, $\mathrm{TcO}_{4}{ }^{-}$co-extracts with uranium into the TBP. After uranium is stripped with dilute nitric acid, $\mathrm{TcO}_{4}{ }^{-}$is stripped from the $\mathrm{TBP}$ with $10 \mathrm{M} \mathrm{HNO}_{3}$. The Tc strip solution can be combined with the HLW raffinate stream or be treated to reduce Tc for incorporation into a metal waste form. In the case of immobilizing the Tc with the UDS into a metal waste form the process would require reduction of the $\mathrm{TcO}_{4}{ }^{-}$to $\mathrm{Tc}^{0}$.

The nitric acid-technetic acid mixture $\left(\mathrm{HTcO}_{4}+\mathrm{HNO}_{3}\right)$ is evaporated at $100^{\circ} \mathrm{C}$ to remove nitric acid. Only a small part of the technetium evaporates with the nitric acid, producing moderately pure $\mathrm{HTcO}_{4} \cdot \mathrm{H}_{2} \mathrm{O}$. The $\mathrm{HTcO}_{4} \cdot \mathrm{H}_{2} \mathrm{O}$ is diluted with water, then reacted with a formaldehyde reducing agent to destroy the remaining nitric acid and reduce technetic acid to a suspension of $\mathrm{TcO}_{2} \cdot \mathrm{nH}_{2} \mathrm{O}$. The suspension of $\mathrm{TcO}_{2} \cdot \mathrm{nH}_{2} \mathrm{O}$ is then mixed with the UDS from the clarifier, evaporated to a dry solid, then reduced to technetium metal at $900^{\circ} \mathrm{C}$ in $\mathrm{H}_{2} / \mathrm{Ar}$. This process is expected to reduce all of the soluble Tc and most of the UDS components to metal but may leave some oxides (the amount of oxide will not be more than 30 mass\% and is expected to be below 10 mass\%). Zirconium and uranium are likely to remain oxides and are expected to combined to produce $\left(\mathrm{Zr}_{x}, \mathrm{U}_{x-1}\right) \mathrm{O}_{2}$ with a fluorite structure, which has been previously studied as a candidate waste form for immobilization of actinides because of its high radiation resistance (Gong et al. 2000).

An alternative Tc recovery process from the uranium dissolved in nitric acid solution is to ion exchange. Dowex Marathon A (styrene-divinyl benzene gel with quaternary amine functional groups) and two Reillex polyvinylpyridine anion exchange resins to remove the Tc from the UREX+ solution have been evaluated in demonstrations: Reillex HPQ (poly-4-vinylpyridine, crosslinked, methyl chloride quaternary salt) and Reillex HP (poly-4-vinylpyridine, crosslinked). The HPQ resin is more selective to $\mathrm{TcO}_{4}{ }^{-}$than the $\mathrm{HP}$ resin; both are more efficient at removing $\mathrm{TcO}_{4}{ }^{-}$from solution than the Dowex Marathon exchanger. The as-received resins are pretreated with a nitric acid solution to replace $\mathrm{Cl}^{-}$on the active sites with $\mathrm{NO}_{3}{ }^{-}$, so $\mathrm{TcO}_{4}{ }^{-}$replaces some of the $\mathrm{NO}_{3}{ }^{-}$on the resin. The Tc can be recovered from the HP resin by elution using $\mathrm{NH}_{4} \mathrm{OH}$ or $\mathrm{NaOH}$. Alternatively, the Tc can be recovered and partially reduced by pyrolysis of the resin followed by steam reforming in $\mathrm{Ar} / \mathrm{H}_{2}$.

Ebert et al. (2009b) have reviewed options for recovering and immobilizing soluble Tc. 


\subsubsection{Iron-Zirconium Based Alloys}

Various Fe-Zr based alloys are expected to accommodate high levels of $\mathrm{Zr}, \mathrm{Mo}, \mathrm{Ru}, \mathrm{Rh}, \mathrm{Pd}$, and $\mathrm{Tc}$ and moderate amounts of oxide contaminants. Two alloys were developed to immobilize residual metallic wastes from the electrochemical treatment of steel-clad and Zircaloy-clad spent sodium-bonded nuclear fuels by processing the waste forms (Abraham et al. 1996, McDeavitt et al. 1998, Abraham et al. 1999). An alloy of stainless steel (SS) with 15-mass\% zirconium (SS-15Zr) was developed for waste streams that were composed predominantly of SS cladding hulls and an alloy of $\mathrm{Zr}$ with 8 mass\% SS (Zr-8SS) was proposed for waste streams that were composed predominantly of Zircaloy cladding hulls. Both of these alloys melted at $1600^{\circ} \mathrm{C}$ using existing furnace technology. The performance of the steel-based alloys was studied intensively to support EBR-II fuel processing waste immobilization (Ebert 2005) and more recently as a potential waste form for UDS and soluble Tc under the GNEP project (Ebert 2008, 2010, 2012; Ebert et al. 2009, 2011; Frank et al. 2012; Olson and Frank 2012; Mausolf et al. 2012). Alloying waste metals with stainless steels generates multi-phase materials comprised of Fe-Mo-Cr, Fe- $\mathrm{Zr}-\mathrm{Ni}$, and Pd-Zr-Ni intermetallics and a steel-like solid solution phase that sequester particular waste elements. Both Tc and Mo report to the Fe-Mo-Cr intermetallic and steel-like solid solution phases. Tc is not found in the Zr-bearing intermetallics that host the $U$ and other actinides. Alloy waste forms can be formulated to generate sufficient amounts of the host phases required to accommodate all of the radionuclides in the waste streams. For example, the lower $U$ contents expected in processed metallic wastes (less than $0.003 \%$ based on Table 1.15) will require less $\mathrm{Zr}$ in the waste forms than do EBR-II wastes, which may contain up to $11 \% \mathrm{U}$ (this includes DU added to down-blend the waste form to LEU levels). The smaller amounts of added $\mathrm{Zr}$ increase the waste loading but do not hinder processing or decrease waste form durability. The measured corrosion behavior and approach to modeling radionuclide release from Fe- $\mathrm{Zr}$ based waste forms is discussed in Section 6.

\subsubsection{Epsilon Metal}

Use of an alloy waste form having a composition similar to the epsilon ( $(\varepsilon)$-metal particles formed during UOX irradiation was investigated for immobilization of the UDS and soluble Tc (Crum and Strachan 2013). Evidence of $\varepsilon$-metal particles were found in the natural reactors located in Gabon, Africa (Gauthier-Lafaye et al. 1996), and Utsunomiya and Ewing (2006) presented evidence that ${ }^{99} \mathrm{Tc}$ migrated only a few centimeters over about 2 billion years although most had been converted to an arsenide. This natural analog data provides evidence that $\varepsilon$-metal may be an attractive waste form to immobilize Tc and $\mathrm{Pd}$, which have long-lived isotopes important to repository performance ${ }^{99} \mathrm{Tc}\left(\mathrm{t}_{1 / 2}=2.13 \times 10^{5} \mathrm{y}\right)$ and ${ }^{107} \mathrm{Pd}$ $\left(\mathrm{t}_{1 / 2}=6.5 \times 10^{6} \mathrm{y}\right)$.

The $\varepsilon$-metal waste form can be fabricated from $100 \%$ waste by consolidating the reduced UDS and soluble Tc, as described in 3.5.2. Two technologies were found to efficiently densify this waste form: HIP and spark-plasma sintering (SPS) (Rohatgi and Strachan 2011, Crum et al. 2012). In both processes pressure and elevated temperatures are combined to densify the metal into a dense and durable waste form. In the HIP process, the waste metal is placed in a metal canister that is evacuated and sealed. The sealed canister is heated under pressure $\left(200 \mathrm{MPa}\right.$ at $\left.1500^{\circ} \mathrm{C}\right)$ to make the final waste form. The final diameter of the HIP cans are as close to inside diameter of the $0.61 \mathrm{~m}$ (OD) canister as possible while leaving enough clearance so that they can be loaded reliably. The estimated design margins are roughly $1.5 \%$ (or $10 \mathrm{~mm}$ ) in diameter and $2 \%$ (or $60 \mathrm{~mm}$ ) in stacked height. The design compressed can height is $0.14 \mathrm{~m}$ and each HIP contains roughly $435 \mathrm{~g}$ of $\varepsilon$-metal with a waste form volume of $0.036 \mathrm{~m}^{3}$ and a HIP can displacement in the canister of $0.040 \mathrm{~m}^{3}$. With this size can, twenty one cans fill a full height $(3 \mathrm{~m})$ disposal canister. Based on an estimated partitioning of the components to the epsilon metal waste form and an assumed density of $12 \times 10^{3} \mathrm{~kg} / \mathrm{m}^{3}$, the process would generate $35 \mathrm{HIP}$ cans per year and 1.67 disposal canisters per year for a $1000 \mathrm{tU} / \mathrm{y}$ plant processing roughly $50 \mathrm{GWd} / \mathrm{tU}$ fuel. The HIP method is 
in the advanced stages of development for nuclear applications in both the U.S. (Balls and Williams 2011; CWI 2009, 2011a, b; EM-TEG 2011; Kluk et al. 2011) and Australia (Carter et al. 2009; Cheung et al. 2012).

Alternately, the SPS process, which is similar to HIP but differs in how the heating occurs, can be used to process the $\varepsilon$-metal. In the SPS process, a batch of $\varepsilon$-metal powder is placed into a graphite die and a direct electric current is pulsed through the graphite die and powder being consolidated to heat each particle from within. The process has a very large initial heating rate that takes the billet temperature to $1525^{\circ} \mathrm{C}$ in seconds. The temperature is reduced slightly and held to complete the alloying and consolidation process. As the samples cools to $1190^{\circ} \mathrm{C}$, pressure is applied causing the pellet temperature to increase and producing a product similar to the HIP process, but without the external canister. The pressures for SPS are lower than for HIP.

Work performed on the $\varepsilon$-metal waste form to date has been done non-radioactively, by substituting $\operatorname{Re}$ for Tc (Strachan et al. 2010; Strachan et al. 2011a). This work shows the $\varepsilon$-metal waste form can be produced by either the SPS or HIP technologies even when dealing with rhenium's high meltingtemperature, as a surrogate for Tc (Rohatgi and Strachan 2011). Other results show that it is possible to fabricate an $\varepsilon$-metal waste form with up to 35 mass\% oxides $\left(\mathrm{ZrO}_{2}\right)(\mathrm{Crum}$ et al. 2013).

Initial durability testing results show the $\varepsilon$-metal waste form is orders of magnitude more durable than borosilicate glass. An alloy composition of 55Ru-20Mo-10Rh-10Pd-5Tc (referred to as EWF-1) was made by arc-melting a mixture of powders to represent epsilon phases in the fuel that is also representative of the $\varepsilon$-metal waste form. Although arc-melting is not a practical production method, it provides a homogenized and densified alloy suitable for investigating the corrosion and Tc release behaviors. Electrochemical corrosion tests indicate the alloy corrodes actively at a low, but measurable, Tc release rate. For example, Figure 3.3 shows linear releases of Tc and other alloy constituents in potentiostatic tests conducted in an acidic brine solution at imposed potentials of $70 \mathrm{mV}$ and $140 \mathrm{mV}$ (Ebert and Cruse 2014). Tc is released preferentially at a rate that quickly becomes constant at $1.6 \times 10^{-3}$ $\mathrm{g} \mathrm{m}^{-2} \mathrm{~d}^{-1}$. Because it is not expected to passivate due to the absence of $\mathrm{Cr}$, and because the pertechnetate ion is highly soluble, the long-term behavior of an $\varepsilon$-metal waste form will be much simpler to model than other waste forms (multi-phase steel alloys or glass). 


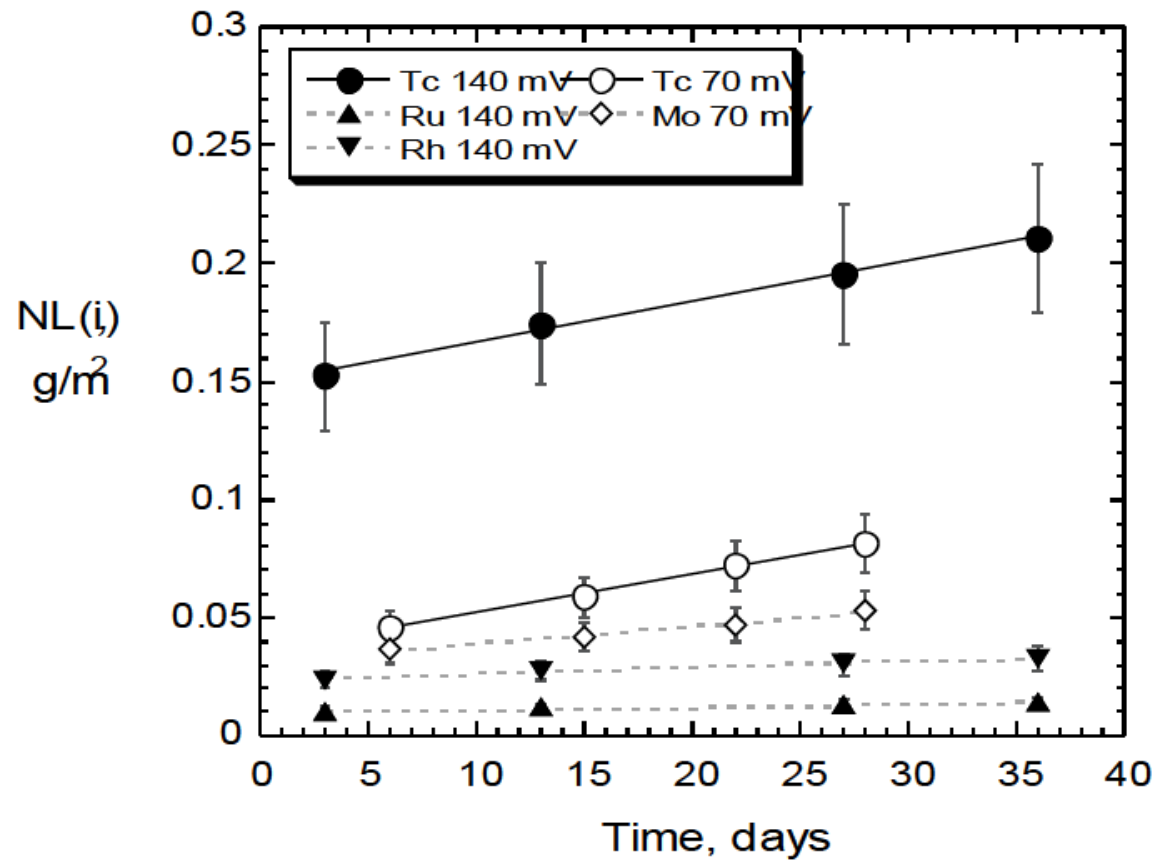

Figure 3.3. Results of Electrochemical Tests with Alloy EWF-1 in Acidic Brine.

In the future, several key questions must be addressed to mature the $\varepsilon$-metal waste form including the development of the technology (preferably guided by a technology maturation plan), development and parameterization of a $\varepsilon$-metal corrosion model, and a revised cost-benefit analyses to help determine the practicality of deploying such a waste process as compared to immobilizing Tc and UDS in the HLW glass or other waste form.

\subsection{Glass Ceramics}

Multi-phase borosilicate-based glass ceramics were investigated as an alternative waste form for immobilizing the combined HLW stream (Crum et al. 2012b,c; 2014). Homogeneous (e.g., single phased borosilicate glass) has been limited by the following component concentration rules:

- $\mathrm{MoO}_{3} \leq 2.5$ mass $\%$

- $\mathrm{RuO}_{2}+\mathrm{PdO}+\mathrm{Rh}_{2} \mathrm{O}_{3} \leq 3$ mass $\%$

- $\mathrm{Cs}_{2} \mathrm{O}+\mathrm{BaO}+\mathrm{SrO}+\mathrm{Rb}_{2} \mathrm{O}+\mathrm{Ln}_{2} \mathrm{O}_{3} \leq 45$ mass $\%(\mathrm{Ln}=$ lanthanide elements plus yttrium $)$

- Decay heat at time of fabrication $\leq 15.1 \mathrm{KW} / \mathrm{m}^{3}$ glass (assuming a $0.43 \mathrm{~m}$ diameter canister)

Glass ceramics provide the opportunity to target chemically durable crystalline phases, e.g., powellite, oxyapatite, cerianite, and pollucite that will incorporate $\mathrm{MoO}_{3}$ as well as other waste components such as lanthanides, alkalis, and alkaline earths at levels twice the solubility limits of a single-phase glass. In addition, a glass ceramic could provide higher decay heat tolerance. The 3 mass $\%$ of noble metal oxides rule is associated with CCIM operation and may not change based on the waste form to be processed. However, the other constraints become more relaxed when changing to a glass ceramic waste form.

Such glass ceramics were developed and tested at crucible scale to determine the loading potential, thermal stability, and ability to form when glass is naturally cooled in the canister to form the final waste form (Crum 2014). The reference glass ceramic studied consists of 6.25 mass $\% \mathrm{MoO}_{3}$ and allows for a 
centerline canister temperature of roughly twice that of a homogeneous glass. With a decay heat limit of $\sim 32 \mathrm{~kW} / \mathrm{m}^{3}$, the loading of glass ceramics is roughly twice that of glass. Figure 3.4 compares the waste loading of homogeneous glass with that of glass ceramics as a function of cooling time since discharge of the fuel (assuming a $50 \mathrm{GWD} / \mathrm{tU}$ burn-up and a flowsheet with the UDS in a separate stream). For the first roughly $40 \mathrm{y}$, the loading of both waste forms are limited by heat and then become chemistry limited at constant values of roughly 19 mass\% (glass) and 55 mass\% (glass ceramics).

Crum et al. (2014) found that the same phases crystallize over a range of cooling rates from $4 \times$ slower to $4 \times$ faster than the canister centerline cooling rate (Figure 3.5), with the morphology changing as expected, with larger crystals forming at slower cooling rates. Measuring the rheology of the melt, Crum et al. $2012 \mathrm{c}$ found that melting could be performed in the range of 1250 to $1350{ }^{\circ} \mathrm{C}$ with crystallization occurring at and below $1100^{\circ} \mathrm{C}$ (Figure 3.6). Above $1100^{\circ} \mathrm{C}$, the melt showed Newtonian rheology while below $1100^{\circ} \mathrm{C}$, a Bingham plastic behavior was seen with increasing yield stress with decrease in temperature.

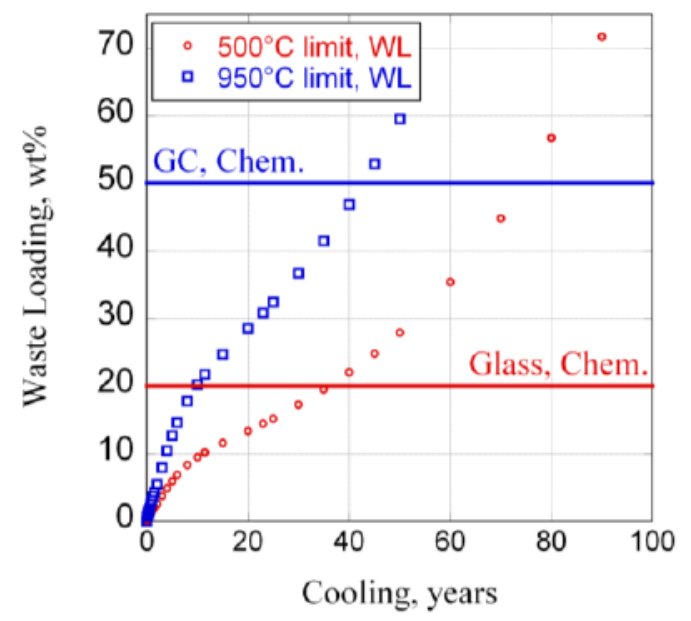

Figure 3.4. Comparison of Waste Loadings between Glass and Glass Ceramics.

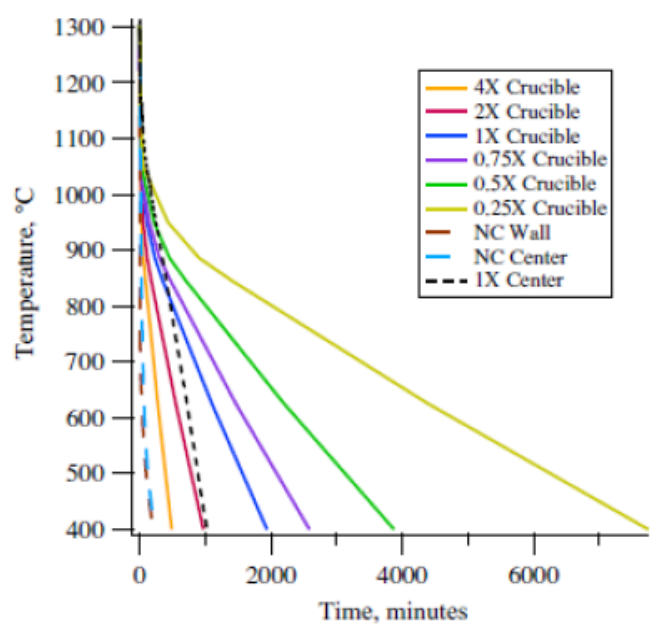

\begin{tabular}{|c|c|c|c|c|c|}
\hline $\begin{array}{l}\text { Cooling } \\
\text { rate }\end{array}$ & $\begin{array}{c}\text { Oxyapatite, } \\
\mathrm{Ca}_{2} \mathbf{L n}_{8} \mathrm{Si}_{6} \mathbf{O}_{26}\end{array}$ & $\begin{array}{c}\text { Pow ellite, } \\
\mathrm{CaMoO}_{3}\end{array}$ & $\left(\mathrm{Zr}_{1-x} \mathrm{Ce}_{x}\right) \mathrm{O}_{2}$ & $\operatorname{Ln}_{3} \mathrm{BSi}_{2} \mathrm{O}_{10}$ & Glass \\
\hline $0.25 x$ & 15.1 & 8.2 & 0 & $\overline{\mathrm{NA}}$ & 76.6 \\
\hline $0.25 x$ & 12.2 & 8.5 & 1.0 & 1.2 & 77.0 \\
\hline $0.5 x$ & 14.6 & 7.8 & 0 & 0 & 77.6 \\
\hline $0.5 x$ & 12.8 & 8.7 & 1.2 & 1.2 & 75.9 \\
\hline $0.75 x$ & 14.7 & 8.4 & 0 & 0 & 76.9 \\
\hline $0.75 x$ & 13.8 & 9.2 & 1.2 & 0.7 & 74.8 \\
\hline $1 x$ & 15.3 & 9.2 & 0 & 0 & 75.6 \\
\hline $1 \mathrm{x}$ & 12.3 & 7.9 & 1.9 & 0.9 & 76.8 \\
\hline $2 x$ & 14.9 & 13.0 & 0 & 0 & 72.1 \\
\hline $2 x$ & 13.2 & 8.3 & 1.2 & 0.8 & 76.4 \\
\hline $4 x$ & 12.2 & 12.5 & 0 & 0 & 75.2 \\
\hline $4 x$ & 11.3 & 7.3 & 0.8 & 1.0 & 79.5 \\
\hline
\end{tabular}

Figure 3.5. Phase Formation as a Function of Cooling Rate (in times of expected natural canister cooling rate, Crum et al. 2012c) 


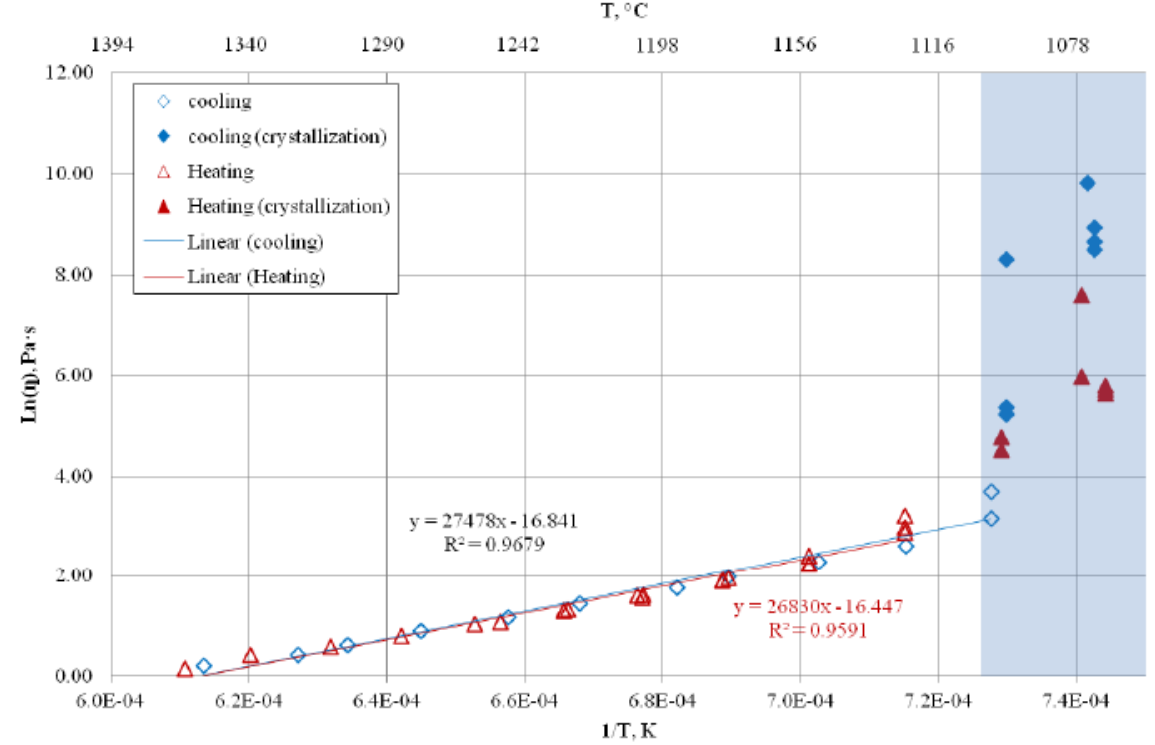

Figure 3.6. Viscosity of Glass Ceramics Melt as a Function of Inverse Temperature (Crum et al. 2014).

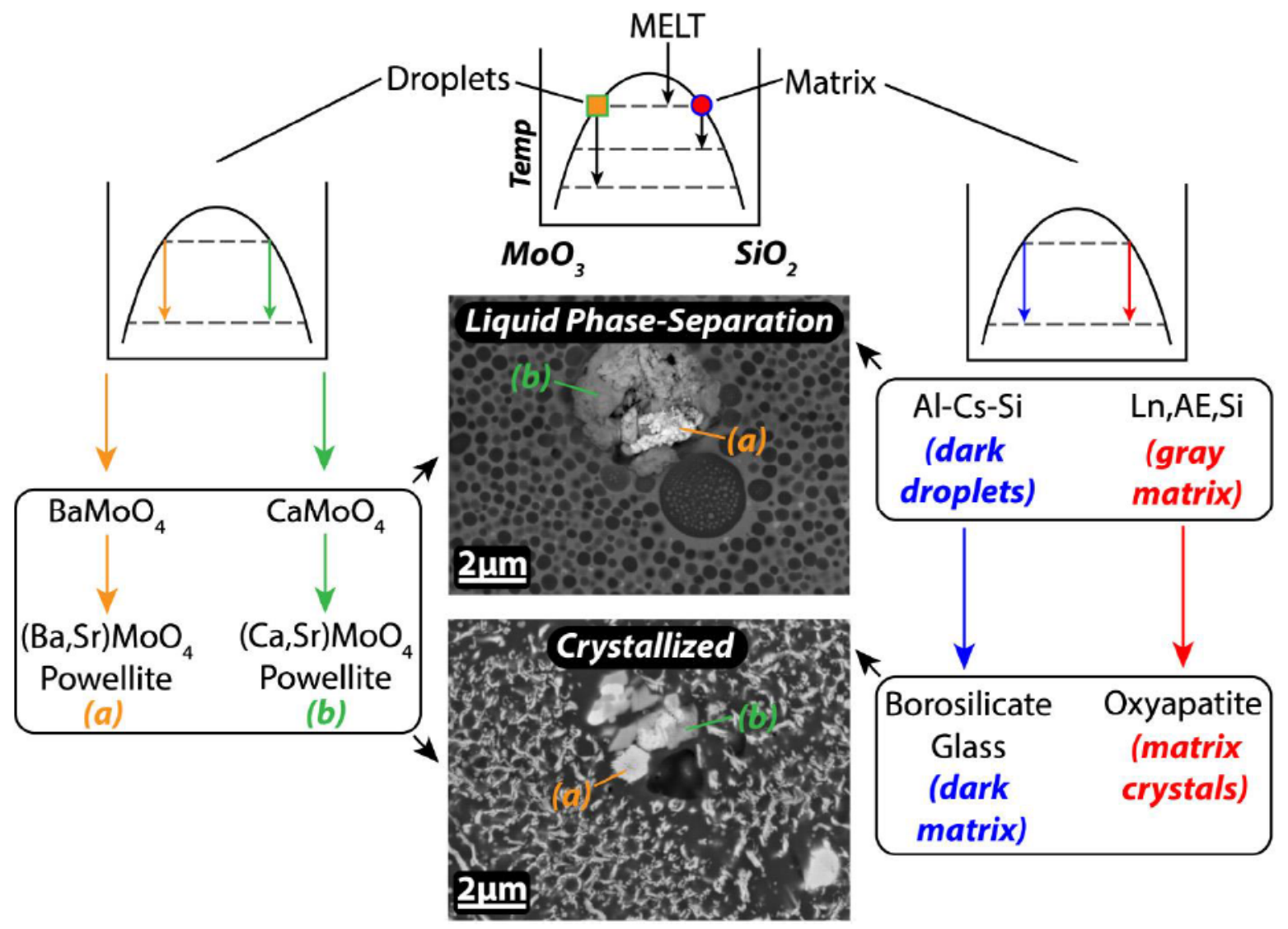

Figure 3.7. Model for Phase Change in Model Glass Ceramic (Crum et al. 2014) 
The reference formulation was melted in an initial cold crucible induction melter (CCIM) test (Crum et al. 2014). The test was successful and produced several small scale (4 inch diameter) cans of waste form that were cooled to mimic different cooling rates that might be experienced at full scale (a nominal full scale canister center cooling $(\times)$, a $2 \times$ rate, and an ambient (fast) cooling). As with the laboratory tests, the phases characterized in the samples showed relatively little variation in the amount of each phase formed for the three cooling rates of $4 \times$ and slower, and three different can.

To better understand the phase formation process, Crum et al. (2014) analyzed phases quenched from heat treatments at progressively lower temperatures. The results suggest two separate immiscible liquid phase separation events followed by crystallization of oxyapatite and powellite from each separate immiscible liquid as shown in Figure 3.7.

As a relatively immature technology, glass ceramics must be further developed and demonstrated before adoption. A technology maturation plan has been developed to guide ongoing research and develop the technology to a sufficient point to be ready for implementation (Vienna et al. 2012).

\subsection{High Level Waste Form Recommendations}

Several HLW forms have been developed and tested over the years. To date, only borosilicate glass and sodium-alumino-phosphate glass have been produced at full scale, with most HLW (as judged by years of production, number of sites, mass of glass, and total activity immobilized) being immobilized in borosilicate glass. It is a good and well understood waste form and process with few drawbacks. It is therefore recommended that glass be the reference waste form for HLW.

Several other waste forms show potential advantages over the reference borosilicate glass waste form. Chief among them are titanate-based ceramics and glass ceramics. The titanate-based waste form will have higher durability and performance that is less dependent on disposal environment (Lutze et al. 1990). However there are technological challenges in safely and reliably fabricating the waste form. Development of a melt processed titanate-based ceramics form/process would allow for the advantages of proven process technology with the benefits of a Synroc waste form. Glass ceramics can increase the loading of glass and thereby reduce the cost of fabrication, storage, transportation, and disposal. Cost analyses have found that higher loading glasses may require longer storage prior to disposal (up to $100 \mathrm{y}$ ). However, there is still a cost benefit. Also, there is potential advantage to glass waste forms from long cooled fuel (and glass ceramics) to separately immobilize UDS (to avoid noble metal limits in the melter). To immobilize UDS, a metal alloy is the most developed and likely most suitable waste form. It is yet to be determined if $\varepsilon$-metal or SS-based alloy would be more effective. Tests are in progress to inform that decision.

\subsection{High-Level Waste Vitrification Process}

The main steps in the HLW vitrification process are receipt and preparation of the waste for feeding to the melter including addition of the glass forming frit, feeding the waste/frit to the glass melter, melting the materials to form the desired waste form (e.g., glass, glass ceramics, titanate ceramics), treating the gaseous effluents from the melting process, pouring the waste form into a disposal canister, and cooling and decontaminating the filled canisters for storage and disposal. The key process steps of feed preparation, melting, and canister filling are described in more detail below.

\subsubsection{Waste Feed Preparation}

Three waste feed streams are combined into a waste feed adjustment vessel in targeted proportions: 
i) concentrated TRUEX raffinate and TALSPEAK lanthanides product (Section 1.1.3),

ii) UDS in a $\sim 4-m a s s \%$ solids slurry with a $0.1 \underline{\mathrm{M}} \mathrm{HNO}_{3}$ base liquid (Section 1.1.1),

iii) combined concentrated decontamination, wash, and recycle streams.

A nominal combined waste stream composition is given in Table 1.5.

The combined HLW is mixed, sampled, analyzed, and transferred to the melter feed preparation vessel. The HLW is mixed with glass frit, a reductant, and any necessary additives to trim to the desired melter feed composition in the melter feed preparation vessel. The nominal frit composition and resulting waste form composition are given in Table 3.7. The frit composition is targeted for a waste loading of 13.7 mass\% that varies with the composition and thermal output of the HLW. For the case used, $50 \mathrm{GWD} / \mathrm{tU}$ as 5-y cooled fuel, the waste loading in glass is limited by decay heat. If the fuel is allowed to cool sufficiently such that decay heat does not limit waste loading, then the waste loading in glass is chemically limited by $\mathrm{MoO}_{3}$ content of 17.9 mass\% for the same fuel and reprocessing assumptions.

Sucrose is added as a reductant and to react with $\mathrm{HNO}_{3}$ in the feed to form $\mathrm{N}_{2}$ and $\mathrm{CO}_{2}$ (Goles et al. 2002, 2001):

$$
20 \mathrm{HNO}_{3}+2 \mathrm{C}_{12} \mathrm{H}_{22} \mathrm{O}_{11} \rightarrow 10 \mathrm{~N}_{2}+24 \mathrm{CO}_{2}+32 \mathrm{H}_{2} \mathrm{O}+\mathrm{O}_{2}
$$

In reality, the reaction does not go to completion and $\mathrm{NO}$ and $\mathrm{NO}_{2}$ are generated from the reaction. The 10:1 mole ratio between nitrate and sucrose has been found to be nearly the ideal ratio for Idaho sodium bearing waste vitrification (Goles et al. 2001, 2002), which is representative of a high nitrate acidic waste vitrified in a liquid-fed test melter.

Table 3.7. Summary of Waste, Frit and Glass Compositions (mass\% of oxides)

\begin{tabular}{|c|c|c|c|}
\hline Oxide & Waste & Additives & Glass \\
\hline $\mathbf{A l}_{2} \mathbf{O}_{3}$ & 0.00 & 6.16 & 5.31 \\
\hline $\mathrm{B}_{2} \mathbf{O}_{3}$ & 0.00 & 16.76 & 14.47 \\
\hline $\mathbf{L i}_{2} \mathbf{O}$ & 0.00 & 3.30 & 2.85 \\
\hline $\mathrm{Na}_{2} \mathrm{O}$ & 0.00 & 11.92 & 10.29 \\
\hline $\mathrm{SiO}_{2}$ & 0.00 & 53.76 & 46.40 \\
\hline $\mathrm{ZnO}$ & 0.00 & 3.60 & 3.11 \\
\hline $\mathrm{BaO}$ & 5.29 & 0.00 & 0.72 \\
\hline $\mathrm{CaO}$ & 0.00 & 4.49 & 3.88 \\
\hline Cs2O & 7.63 & 0.00 & 1.04 \\
\hline$[\mathbf{L n}, \mathbf{A n}]_{2} \mathbf{O}_{3}$ & 35.07 & 0.00 & 4.80 \\
\hline $\mathrm{MoO}_{3}$ & 13.95 & 0.00 & 1.91 \\
\hline NMO & 14.70 & 0.00 & 2.01 \\
\hline $\mathrm{ZrO}_{2}$ & 13.98 & 0.00 & 1.92 \\
\hline Others & 9.39 & 0.00 & 1.29 \\
\hline Total & 100.00 & 100.00 & 100.00 \\
\hline mass\% loading & 13.70 & 86.30 & 100.00 \\
\hline kg Oxide/tU & 54.22 & 342 & 396 \\
\hline $\mathrm{m}^{3} / \mathrm{tU}$ & & & 0.152 \\
\hline
\end{tabular}

\subsubsection{Melting Process}

Vitrification processes vary in the way that the melter waste is prepared, dried, and fed to the melter, the melter construction materials, and how the melter is heated. The two feeding methods are: 1) liquid waste mixed with frit and fed directly into the melter and 2) the waste is first calcined (with the reductant) and the calcine and frit are metered separately into the melter. The former is used in the U.S., FRG, China, and Japan while the latter is used in France and England (Vienna 2010). The advantage of the calcine method is that the feed is dried and the nitrates are reacted in a more efficient process, as compared to 
liquid or slurry feed in which the waste is dried and the nitrates destroyed in the melter. The primary disadvantage of the calcination method is the high maintenance requirements with a high-temperature rotating unit with a beater bar that must maintain gas tightness. The liquid feeding method has the primary disadvantage of a lower processing rate due to the need for drying and nitrate reaction in the melter. In contrast, the primary advantage is the simplicity of design and reduced maintenance requirements.

The five melter options are (Vienna 2010):

1. The liquid-fed, Joule-heated, ceramic melter (LFCM) in which liquid waste is the feed and heat is supplied by passing electrical current through the low electrical conductivity melt, thereby generating Joule-heat (resistance heating). This melter has the advantages that the ceramic refractories have low corrosion rates and, thus, have long service life (on the order of ten years or more), they can be scaled to very large sizes and therefore very large throughputs. The disadvantages are the temperature limits imposed by electrode stability (typically $\leq 1200^{\circ} \mathrm{C}$ for Inconel 690 electrodes) and the large melter size that must eventually be disposed of as highly radioactive waste.

2. The hot-walled, induction melter (HWIM) is a metal can that is heated by low-frequency induction (coupled directly to the metal melt container). The heat is transferred from the container to the waste calcine plus glass frit or waste calcine plus glass additives to form the glass melt. The advantages of this melter are the simplicity of design, no electrical conductivity constraints, and small size. The primary disadvantages are the inability to scale up beyond roughly $0.5 \mathrm{~m}$ (for the narrowest dimension) without significant reduction in heating efficiency, the low temperature limits ( $\leq 1100^{\circ} \mathrm{C}$ for high Ni alloys, but higher for platinum alloys), and the low melter life (typically $<1$ y). These two disadvantages both significantly reduce the throughput rate and thereby are typically only deployed with calciners to increase the waste processing rate.

3. The cold-crucible induction melter (CCIM) is fabricated from segmented, water cooled, metal tubes (or sleeves). A radio frequency current passes through induction coils surrounding the melter. This current inductively couples directly to the glass melt creating a current in the melt that generated Joule-heating. The cooled wall maintains a solid glass shell as the "melt contact" material. The advantages of this melter are high melting temperatures $\left(1500^{\circ} \mathrm{C}\right.$ or higher if needed and appropriately designed), high resistance to corrosive melts, tolerance to solid inclusions, small size, high specific throughput, and the ability to completely cool and empty. The disadvantages are small maximum size ( $\leq 1.4 \mathrm{~m}$ diameter), the need to manage radio frequency, and low energy efficiency.

4. The hot-walled resistance heated melter (HWRM) is similar to the HWIM with the exception that the heat is supplied to the canister by resistance heating. The advantages and disadvantages are very similar to the HWIM.

5. The in-can melter (ICM) is a version of the HWIM or HWRM in which the melt is not cast out of the melter but instead, the melt container is removed from the heat source and becomes the disposal canister. The advantage of this melter, as compared to the HWIM and HWRM is that the melter can be used for more corrosive melts as the lifetime is a single melt, and the ability to process multi-phase materials with problematic melt rheologies as the melt is never cast (e.g., no noble metal limts).

Table 3.8 summarizes the current HLW melting methods and Table 3.2 summarizes the application of these melter technologies for nuclear waste glass production. 
Table 3.8. Summary of Melt Process Methods

\begin{tabular}{|c|c|c|c|}
\hline Concept & Melter Feed & $\begin{array}{c}\text { Glass Contact } \\
\text { Material }\end{array}$ & Heating Method \\
\hline $\begin{array}{l}\text { Liquid Fed, Ceramic } \\
\text { Melter (LFCM) }\end{array}$ & $\begin{array}{l}\text { Mix frit/additives to HLW, } \\
\text { directly feed slurry onto melt } \\
\text { surface }\end{array}$ & Ceramics & $\begin{array}{l}\text { Joule-heat the melt using } \\
\text { submerged electrodes }\end{array}$ \\
\hline $\begin{array}{l}\text { Hot Walled Induction } \\
\text { Melter (HWIM) }\end{array}$ & $\begin{array}{l}\text { Calcine waste, meter waste and } \\
\text { frit onto melt surface }\end{array}$ & Metal & $\begin{array}{l}\text { Inductively heat the metal } \\
\text { container (low frequency) }\end{array}$ \\
\hline $\begin{array}{l}\text { Cold Crucible } \\
\text { Induction Melter } \\
\text { (CCIM) }\end{array}$ & $\begin{array}{l}\text { Calcine waste, meter waste and } \\
\text { frit onto melt surface, or direct } \\
\text { liquid feed }\end{array}$ & Solid Glass & $\begin{array}{l}\text { Inductively heat the melt (radio } \\
\text { frequency) }\end{array}$ \\
\hline $\begin{array}{l}\text { Hot Walled } \\
\text { Resistance Melter } \\
\text { (HWRM) }\end{array}$ & $\begin{array}{l}\text { Meter frit and HLW onto melt } \\
\text { surface }\end{array}$ & Metal & Resistively heat the metal \\
\hline $\begin{array}{l}\text { In-Canister Melter } \\
\text { (ICM) }\end{array}$ & $\begin{array}{l}\text { Calcine waste, meter waste and } \\
\text { frit onto melt surface, or direct } \\
\text { liquid feed }\end{array}$ & $\begin{array}{l}\text { Metal or } \\
\text { graphite }\end{array}$ & $\begin{array}{l}\text { Resistance or low frequency } \\
\text { induction heat }\end{array}$ \\
\hline
\end{tabular}

For the purposes of this application, a liquid-fed CCIM has been selected as the baseline technology. The high temperature processing and tolerance to solid inclusions will allow for advanced waste forms and allow for sufficient processing rate mitigate the need for calcination.

The liquid melter feed is mixed and fed to a CCIM operating at roughly $1300{ }^{\circ} \mathrm{C}$. As the melter feed enters the melter, it flows across the melt surface and dries to form a cold cap which insulates the melt and reduces the loss of semi-volatile components. The $1300^{\circ} \mathrm{C}$ melt heats and eventually dissolves the material at the bottom of the cold cap to increase the mass of the melt. The melt is periodically cast into a stainless steel canister where it cools to form a solid glass waste form. In normal operating conditions, each pour is no more than a third of the melt volume. An estimate of glass produced is between 300 (for 50 year cooled fuel) and 570 (for 5 year cooled fuel) MT per year based on an overall fuel reprocessing rate of $1000 \mathrm{MT} / \mathrm{y}$. The specific throughput rate of a liquid fed CCIM with similar high-nitrate feed isn't currently known. However, it is estimated in the range from 900 to $2000 \mathrm{~kg} / \mathrm{m}^{2} / \mathrm{d}$ of glass based on the results of:

- liquid-fed Joule heated melter test with high nitrate SBW glass at $1150{ }^{\circ} \mathrm{C}$ ranging from 900 to $1000 \mathrm{~kg} / \mathrm{m}^{2} / \mathrm{d}$ (Goles et al. 2002, 2001);

- liquid-fed CCIM tests with U.S. defense HLWs ranging from 1000 to $2000 \mathrm{~kg} / \mathrm{m}^{2} / \mathrm{d}$ (Marra 2013);

- liquid-fed Joule heated melt tests with U.S. defense HLWs ranging from 800 to $2000 \mathrm{~kg} / \mathrm{m}^{2} / \mathrm{d}$ (see for example Matlack 2007, 2008);

- calcine-fed full scale pilot CCIM facility operating at Marcoule with simulated commercial HLW of $2900 \mathrm{~kg} / \mathrm{m}^{2} / \mathrm{d}$ (Naline et al. 2010);

- liquid-fed CCIM test at INL with an initial estimate of commercial HLW to generate a glass ceramic obtained a rate of $\sim 1500 \mathrm{~kg} / \mathrm{m}^{2} / \mathrm{d}$ (Maio 2013, 2014).

With this range of glass volume and melter-specific throughput, it is assumed that a vitrification process consists of two CCIMs scaled between 0.62 and $1.13 \mathrm{~m}$ as shown in Table 3.9. These scales assume a total online efficiency (TOE) of $70 \%$, which translates to 255 days a year of processing. The $70 \% \mathrm{TOE}$ is a reasonable assumption, if there is sufficient vessel capacity to decouple the separations and vitrification processes by $\sim 30$ days. This range of scale is well within the range for which CCIMs are efficient, for example: the LaHague R7 CCIM is $0.65 \mathrm{~m}$ (Naline et al. 2010), the Ulchin CCIM is $0.85 \mathrm{~m}$ (Park 2010), and the Marcoule test CCIMs range up to $1.1 \mathrm{~m}$ (Bonnetier et al. 2003). Larger commercial (e.g., nonnuclear) applications of CCIM in specialty materials manufacturing have been used successfully at Ferro 
corporation with a $1.2 \mathrm{~m}$ diameter CCIM (since 1998) (Boen et al. 1998). Also, detailed design of a 1.4$\mathrm{m}$ diameter CCIM was conducted for implementation in the Defense Waste Processing Facility (DWPF) (Lauzel and Thurin 2009).

Table 3.9. Maximum Melter Feed Concentrations, grams of glass per liter of melter feed.

\begin{tabular}{|c|c|c|}
\hline Fuel Age, $\mathbf{Y}$ & Dilute & Concentrated \\
\hline 5 & 112 & $500^{(\mathrm{a})}$ \\
\hline 50 & 59 & 461 \\
\hline \multicolumn{3}{|c|}{ (a) Melter feed in $>500 \mathrm{~g} / \mathrm{L}$ may be } \\
problematic for production. Therefore, a limit \\
of $500 \mathrm{~g} / \mathrm{L}$ is assumed. \\
\hline
\end{tabular}

The feed components entering the melter reacts and individual components partition differently between the melt (and ultimately glass) and the off-gas stream. Partitioning to the off-gas is by two primary mechanisms: volatilization and particulate and aerosol entrainment.

\subsubsection{HLW Glass Canister}

The melt exiting the melter is poured directly into a stainless steel canister that becomes part of the final waste package. Three canister dimensions are currently being assumed for HLW management in the U.S., France, the U.K., and Japan:

- The universal container for vitrified waste (UC-V) is used in France, the U.K., and Japan. It is the smallest of the three current canisters options ( $1.3 \mathrm{~m}$ tall and $0.43 \mathrm{~m}$ wide). It has the advantages of better heat removal (for the potential of higher waste loading) and a lower height (that allows for shorter hot cell and easier mechanical manipulation). It has the disadvantages of less effective volume utilization (canisters are typically filled to roughly $0.3 \mathrm{~m}$ of capacity), and more canisters for handling.

- The West Valley Demonstration Project (WVDP) or the distinct (but similarly sized) Defense Waste Processing Facility canister is taller and slightly wider than the UC-V $(3 \mathrm{~m}$ tall and $0.6 \mathrm{~m}$ wide). So, this canister has better fill efficiency, requires a taller hot cell, presents more challenging handling, has less effective heat removal, and requires the handling of fewer glassfilled canisters.

- The WTP canister is the same diameter as the WVDP canister, but is the tallest of the three canisters at $4.5 \mathrm{~m}$. This canister requires the tallest hot cell and the most difficult manipulations. But, this canister also has the highest volumetric fill efficiency and requires the handling of the fewest canisters in production, storage, transportation, and disposal.

Table 3.10 summarizes these three canister options. There are, of course, an infinite number of potential canister options including 8.5 inch $(0.216 \mathrm{~m})$ diameter canisters appropriate for deep borehole disposal. The UC-V canister has been selected for the purposes of this study. Without a detailed facility design, the advantages of heat dissipation favor this canister over the larger diameter canisters resulting in $1.65 \times$ increase in waste loading for $5 \mathrm{y}$ cooled fuel. 
Table 3.10. Summary of Evaluated HLW Canister Options for Glass for $1000 \mathrm{tU} / \mathrm{y}$ Reprocessing Plant

\begin{tabular}{|c|c|c|c|}
\hline Parameter & $\overline{\mathrm{UC}-\mathrm{V}}$ & WVDP & WTP \\
\hline Diameter, $\mathbf{m}$ & 0.43 & 0.61 & 0.61 \\
\hline Height, $m$ & 1.34 & 3 & 4.5 \\
\hline Volume, $\mathbf{m}^{3}$ & 0.195 & 0.877 & 1.315 \\
\hline Fill Volume, $\mathrm{m}^{3}$ & 0.156 & 0.75 & 1.17 \\
\hline Empty mass, kg & 90 & 500 & 700 \\
\hline Glass density, $\mathrm{kg} / \mathrm{m}^{3}$ & 2600 & 2,600 & 2600 \\
\hline Glass mass, kg & 400 & 1980 & 3040 \\
\hline Canisters/y assuming 5-y cooled fuel (t/y glass) & $989(401)$ & $339(661)$ & $217(661)$ \\
\hline Canisters/y assuming $50-y$ cooled fuel (t/y glass) & $748(302)$ & $155(302)$ & $99(302)$ \\
\hline
\end{tabular}

The HLW glass canisters are cast in "lifts" or pours of between roughly 145 and $550 \mathrm{~kg}$ of glass per lift (depending on melter scale). The lift size is estimated assuming a melter height of $0.7 \mathrm{~m}$ and a melt height before and after a lift of $\sim 0.525$ and $\sim 0.35 \mathrm{~m}$, respectively. This lift size maintains roughly $2 / 3$ of the melt in the melter at all times to improve process stability. A UC-V canister requires between 1 and 3 lifts to fill.

The HLW glass canisters are decontaminated prior to storage and transportation. Three primary means are used to decontaminate canisters: 1) frit blasting, 2) chemical etching, 3) high-pressure spray, and 4) $\mathrm{CO}_{2}$ pellet blasting. For the purposes of this study, it is assumed that $\mathrm{CO}_{2}$ pellet blasting is used, since this method is the least impacted by high decay heat from the canistered waste form and minimizes the amount of secondary waste.

\subsubsection{Glass Ceramics}

An alternate flowsheet is considered with glass ceramics and a second HLW form for the UDS and soluble technetium streams which are not sent to the vitrification process. An example glass frit and its associated glass ceramic waste form formulation are listed in Table 3.11.

Table 3.11. Summary of Waste, Frit, and Glass Ceramic Compositions (mass\%).

\begin{tabular}{|l|r|r|r|}
\hline Oxide & Waste & Additives & $\begin{array}{r}\text { Glass } \\
\text { Ceramic }\end{array}$ \\
\hline $\mathbf{A l}_{2} \mathbf{O}_{3}$ & 0.00 & 11.81 & 6.50 \\
\hline $\mathbf{B}_{\mathbf{2}} \mathbf{O}_{3}$ & 0.00 & 14.54 & 8.00 \\
\hline $\mathbf{C a O}$ & 0.00 & 7.74 & 4.26 \\
\hline $\mathbf{L i}_{2} \mathbf{O}$ & 0.00 & 3.54 & 1.95 \\
\hline $\mathbf{N a}_{2} \mathbf{O}$ & 0.00 & 2.73 & 1.50 \\
\hline $\mathbf{S i O}_{\mathbf{2}}$ & 0.00 & 59.63 & 32.81 \\
\hline $\mathbf{Z r O}_{2}$ & 16.58 & 0.00 & 7.46 \\
\hline $\mathbf{M o O}_{3}$ & 9.12 & 0.00 & 4.10 \\
\hline$(\mathbf{A c}, \mathbf{L n})_{2} \mathbf{O}_{3}$ & 44.31 & 0.00 & 19.93 \\
\hline$(\mathbf{B a}, \mathbf{S r}) \mathbf{O}$ & 10.37 & 0.00 & 4.66 \\
\hline$(\mathbf{C s}, \mathbf{R b})_{2} \mathbf{O}$ & 11.33 & 0.00 & 5.10 \\
\hline Noble Metal Oxides & 5.50 & 0.00 & 2.48 \\
\hline Others & 2.79 & 0.00 & 1.25 \\
\hline Total & 100.00 & 100.00 & 100 \\
\hline Mass\% Loading & 45 & 55 & 100 \\
\hline kg Oxide/tU Processed & 41.47 & 50.73 & 92.20 \\
\hline $\mathbf{m}^{3} /$ tU Processed & & & 0.030 \\
\hline
\end{tabular}


At an anticipated glass ceramic waste loading range of 19.4 to 54.5 for wastes from 5 - and 50 -y cooled fuels, respectively, the anticipated canister production rate and melter scales are shown in Table 3.12 and Table 3.13. For the glass ceramic waste form, only a single CCIM operating at $70 \% \mathrm{TOE}$ is assumed (where for the glass waste form two CCIMs are assumed).

Table 3.12. Summary of Evaluated HLW Canister Options for Glass Ceramic Vitrification

\begin{tabular}{|l|r|r|r|}
\hline \multicolumn{1}{|c|}{ Parameter } & \multicolumn{1}{c|}{ UC-V } & \multicolumn{1}{c|}{ WVDP } & \multicolumn{1}{c|}{ WTP } \\
\hline Glass ceramic mass, $\mathbf{~ k g / c a n ~}$ & 476 & 2288 & 3569 \\
\hline Glass ceramic density, kg/m $\mathbf{m}^{3}$ & 3050 & 3050 & 3050 \\
\hline Canisters/y 5y cooled fuel (t/y glass) & $451(214)$ & $152(348)$ & $97(348)$ \\
\hline $\begin{array}{l}\text { Canisters/y 50y cooled fuel (t/y } \\
\text { glass) }\end{array}$ & $160(76)$ & $33(76)$ & $21(76)$ \\
\hline
\end{tabular}

Table 3.13. Summary of Glass Ceramic Production Rate and Melter Scales (assuming a single line with concentrated feed)

\begin{tabular}{|l|c|c|}
\hline Parameter & \multicolumn{2}{|c|}{ Fuel Age } \\
\hline Cooling Time & $\mathbf{5} \mathbf{~}$ & $\mathbf{5 0} \mathbf{~}$ \\
\hline Mass/1000 tU processed & $214 \mathrm{t}$ & $76 \mathrm{t}$ \\
\hline Melter feed concentration, $\mathbf{g} / \mathbf{L}$ & 348 & 118 \\
\hline Specific melter throughput, $\mathbf{~ k g} / \mathbf{m}^{2} / \mathbf{d}$ & 425 & 1253 \\
\hline Melter diameter, $\mathbf{m}$ & 0.95 & 0.95 \\
\hline
\end{tabular}

\subsection{Data Gaps and Research Needs}

The development of an integrated reprocessing plant/HLW process system that efficiently meets all of the regulatory requirements is a significant challenge. New higher performing waste forms are now possible with additional development and challenges in waste processing need to be addressed. The data gaps and research needs are separated by waste form below.

\subsubsection{Borosilicate Glass}

Borosilicate HLW glass is the most demonstrated and deployed HLW waste form worldwide. However, the process in this study has proposed combining new advancements in the technology that have not been combined and demonstrated yet.

- The use of a liquid-fed CCIM and a coupled MOG system capable of meeting all the U.S. off-gas treatment requirements needs to be demonstrated and modified as necessary.

- The performance of HLW glass is still the subject of significant uncertainty (Vienna et al. 2013). The development of an international consensus long-term glass corrosion model is a high-priority research endeavor that will allow for a technically defensible and not overly conservative assessment of glass performance in a range of likely geologic disposal environments.

- The glass formulation needs to be optimized for application to the specific waste stream and facility constraints.

\subsubsection{Borosilicate Glass Ceramics}

A technology maturation plan has been developed for the glass ceramic waste form and vitrification process (Vienna et al. 2012). This maturation plan describes the high priority data gaps and research needs in detail. They can be summarized as follows: 
- Complete an evaluation of the waste to be treated.

- Laboratory scale glass ceramic testing to refine the formulation and develop a composition and thermal history envelope for which the waste form is adequate.

- Melter and off-gas testing with simulants to develop the process for forming the waste form and determine the appropriate processing parameters and range of processability.

- Complete preliminary design of a waste process to guide pilot testing and engineering studies.

- Integrated pilot testing of the waste process to collect engineering data.

- Develop a waste compliance plan that describes how the multiphase glass ceramic waste form will be qualified for disposal.

- Perform waste form durability testing to determine the mechanisms for radionuclide release, develop a long-term performance model framework, and parameterize the performance model.

\subsubsection{Titanate-Based Ceramics}

- Optimize the melting and crystallization process to obtain desired product quality while minimizing volatility. This will require composition optimization, cold cap control, pouring/cooling optimization, off-gas recycle strategies, etc.

- Perform detailed characterization to determine elemental partitioning in phases, grain boundaries, etc. to facilitate product control strategy and product qualification.

- Develop a fundamental understanding of product durability including durability of individual end member phases, minority phases and grain boundary phases as related to durability of multiphase product.

- Develop a waste compliance plan that describes how the multiphase ceramic waste form will be qualified for disposal.

\subsubsection{Metal Waste Forms for UDS and Tc}

- Develop the process for $\varepsilon$-metal and Fe-based alloy fabrication to include the reduction of Tc from nitrate solution and the consolidation process.

- Generate sufficient data on the Fe-based alloy and the $\varepsilon$-metal and other HLW forms (e.g., glass ceramics and titanate-based ceramics) and perform trade study to determine the potential benefits and costs of separating the UDS and Tc for immobilization in a separate form.

- Develop a model for the long-term performance of metal waste forms potentially containing oxide inclusions valid for a range of disposal environments.

- Demonstrate the fabrication process for metal waste forms.

- Develop a waste compliance plan that describes how the multiphase alloy waste form will be qualified for disposal.

- Determine the process and composition range for qualified and processable waste forms. 


\section{HULLS AND HARDWARE FROM LWR FUEL}

\subsection{Waste Stream Definition}

The waste streams that are considered in this section include the cladding hulls and the hardware that is part of the boiling water reactor (BWR) and pressurized water reactor (PWR) fuel assemblies. Although various assembly designs will be processed, an example of the hulls and hardware assembly composition is given in Table 4.1. These include Zircaloy-2 and Zircaloy-4 cladding used in PWR and BWR assemblies, respectively, and other components made of Zircaloy-2 and -4, various stainless steels, and various Inconels. The overall compositions of the combined materials were assumed to be those of the reference assemblies. Table 4.2 lists the compositions of representative alloys.

Table 4.1. Example List of Non-Fuel Parts in Typical UNF Assemblies (OCRWM 2008)

\begin{tabular}{|c|c|c|}
\hline Part & Material & kg/assembly \\
\hline \multicolumn{3}{|c|}{ Pressurized Water Reactor } \\
\hline Cladding (208 rods) & Zircaloy-4 & 115 \\
\hline Nozzles & SS CF3M & 15.6 \\
\hline Spring retainer & SS CF3M & 0.91 \\
\hline Hold down spring & Inconel-718 & 1.8 \\
\hline Upper end plug & SS 304 & 0.06 \\
\hline Nuts & SS 304L & 0.66 \\
\hline Spacers & Inconel-718 & 7.2 \\
\hline Guide tubes & Zircaloy-4 & 8.0 \\
\hline Grid supports & Zircaloy-4 & 0.64 \\
\hline Instrument tube & Zircaloy-4 & 0.64 \\
\hline Plenum springs & Inconel-718 & 0.042 \\
\hline Plenum spacer & Inconel-718 & 1.04 \\
\hline \multicolumn{3}{|c|}{ Boiling Water Reactor } \\
\hline Cladding (64 rods) & Zircaloy-2 (or SS $348 \mathrm{H}$ ) & 37.2 \\
\hline Tie plates & SS 304 & 6.77 \\
\hline Compression spring & Inconel X-750 & 0.580 \\
\hline Channel & Zircaloy-4 & 38.6 \\
\hline Water rod & Zircaloy-2 (or SS $348 \mathrm{H}$ ) & 121 \\
\hline Getters & SS 304 & 0.617 \\
\hline Plenum springs & SS 304/Inconel X-750 & 1.700 \\
\hline Spacer grids & Zircaloy-4 (or Inconel X-750) & 1.950 (or 0.325$)$ \\
\hline
\end{tabular}

The cleaned hulls and hardware contain neutron activation products generated in the reactor: activation products with short half-lives include ${ }^{55} \mathrm{Fe},{ }^{60} \mathrm{Co}$, and ${ }^{63} \mathrm{Ni}$, and activation products with long half-lives include ${ }^{14} \mathrm{C},{ }^{59} \mathrm{Ni},{ }^{93} \mathrm{Nb}$, and ${ }^{99} \mathrm{Tc}$. The hulls contain TRU and FP embedded in the inner 60 to $150 \mu \mathrm{m}$ of the hull surface due to alpha recoil ejecting fuel components into the zirconium. These affect the handling and disposal of the wastes. Based on results from calculations on the combined materials in the cladding and hardware from both BWR and PWR assemblies, both the hulls and hardware will exceed the Class C waste limits (Gombert et al. 2007). This is due primarily to activation products in the SS hardware and TRU in the hulls. An effort to leach the hulls and render them less than Class C waste was ineffective (Rudisill 2008). The ${ }^{90} \mathrm{Sr}$ and ${ }^{137} \mathrm{Cs}$ concentrations were reduced to below the Class B limits after removing $120 \mu \mathrm{m}$ of the hull surfaces by leaching in HF. The TRU concentrations significantly decreased in the first $40 \mu \mathrm{m}$, but remained above the Class C limits $(100 \mathrm{nCi} / \mathrm{g})$ after etching to as deep as $180 \mu \mathrm{m}$. 
Table 4.2. Representative Compositions of Stainless Steels and Zircaloys, mass\%

\begin{tabular}{|c|c|c|c|c|c|}
\hline Element & Type HT-9 $^{\mathrm{a}}$ & Type 304 & Type 316 & Zircaloy-2 $^{\text {b }}$ & Zircaloy-4 $^{\mathrm{b}}$ \\
\hline $\mathrm{C}$ & 0.21 & 0.08 (max.) & 0.08 (max.) & 0.027 & 0.027 \\
\hline $\mathrm{Cr}$ & 11.94 & $18-20$ & $16-18$ & $0.05-0.15$ & \begin{tabular}{|l|}
$0.07-0.13$ \\
\end{tabular} \\
\hline $\mathrm{Fe}$ & balance & balance & Balance & $0.07-0.20$ & \begin{tabular}{|l|}
$0.18-0.24$ \\
\end{tabular} \\
\hline Mn & 0.69 & $2.0(\max )$ & 2.0 (max.) & 0.0050 & 0.0050 \\
\hline Mo & 1.03 & - & $2-3$ & 0.0050 & 0.0050 \\
\hline $\mathbf{N i}$ & 0.62 & $8-12$ & $10-14$ & $0.03-0.08$ & 0.0070 \\
\hline $\mathbf{P}$ & 0.013 & 0.045 (max.) & 0.045 (max.) & - & - \\
\hline $\mathbf{S}$ & - & 0.03 (max.) & 0.03 (max.) & - & - \\
\hline $\mathbf{S i}$ & 0.30 & $1.0(\max )$. & $1.0(\max )$. & 0.012 & \begin{tabular}{|l|}
0.012 \\
\end{tabular} \\
\hline Sn & - & - & - & $1.20-1.70$ & $1.20-1.70$ \\
\hline W & 0.48 & - & - & - & - \\
\hline $\mathrm{Zr}$ & - & - & - & balance & balance \\
\hline
\end{tabular}

Most of the hardware will be separated from the cladding prior to chopping for dissolution, and the cladding hulls will be separated from oxide fuel either by dissolution or by TPT (if performed). The separated cladding may contain small amounts of undissolved fuel, adhering actinide and fission product contaminants, and corrosion and deposition products (crud), all of which will be removed from the hulls in a separate cleaning process before hull disposal.

The reference fuel will contain $254 \mathrm{~kg} / \mathrm{tU}$ of Zircaloy-4 cladding and $47 \mathrm{~kg} / \mathrm{tU}$ of SS parts.

\subsection{Management Approaches for Hulls and Hardware}

Traditionally, hulls and hardware have been managed together. The most common approaches to managing these wastes are to wash (and/or leach) and then 1) embed in cement for disposal, 2) dispose directly, or 3) compact and dispose. A number of alternative approaches have been identified in Management of Cladding Hulls and Fuel Hardware (IAEA 1985):
a. Rolling compaction and cementation
b. Embedding in graphite
c. Compaction with malleable metals (powder metallurgical encapsulation)
d. Compaction and encapsulation in low temperature metals
e. Glass encapsulation
f. Cryogenic crushing and encapsulation
g. Oxidation and conversion to ceramic waste forms (e.g., zircon)
h. Oxidation and cementation
i. Hot pressing
j. Melting to a $\mathrm{Zr}-\mathrm{Fe}$ alloy

An additional option of zirconium separation using reactive gases has been under development in Canada and the U.S. (Collins et al. 2011). Although these methods are not being currently implemented, many show promise for improved waste management compared to the reference technologies.

Decisions on the treatment of hulls and hardware must consider aspects of safety (e.g., fires initiated by $\mathrm{Zr}$ metal fines), environmental impacts (e.g., tritium release during thermal or chemical processing), cost (e.g., comparing the cost of higher disposal volumes with the cost to build and operate a process unit), and waste form performance (e.g., the difference in radionuclide releases from processed and unprocessed 
hulls). Figure 4.1 shows schematically the process options for hulls and hardware. Several options are discussed in the following sections.

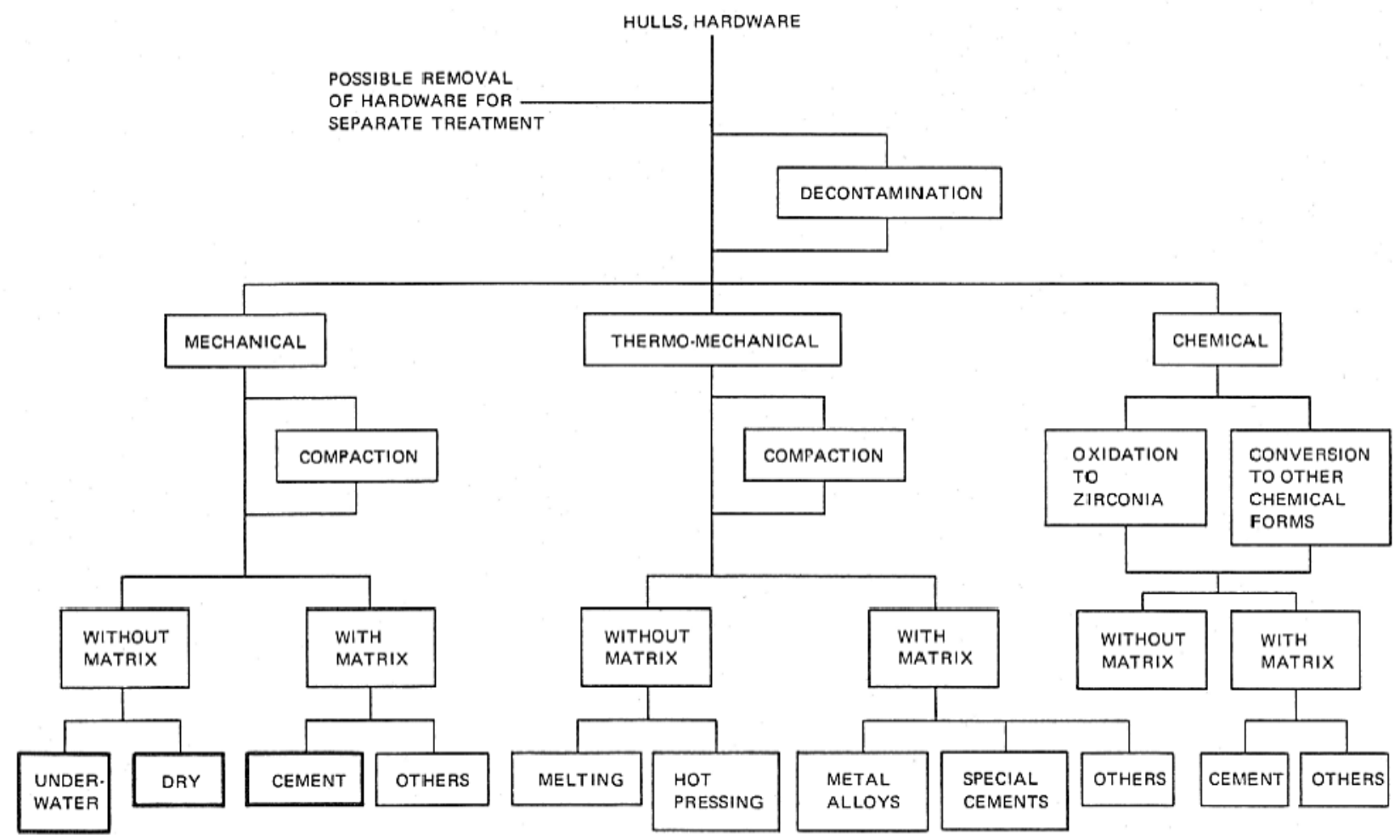

Figure 4.1. Schematic of Process Options for Hulls and Hardware from (IAEA 1985).

\subsubsection{Cementation}

The main advantages of immobilization by physical encapsulation in cement are:

- inexpensive and readily available cements;

- simple and low-cost processing at ambient temperature;

- cement matrix acts as a diffusion barrier and provides sorption and reaction sites;

- suitable for sludge, liquors, emulsified organic liquids and dry solids;

- good thermal, chemical and physical stability of waste-form;

- alkaline chemistry which ensures low solubility for many key radionuclides;

- non-flammability of waste-form;

- good waste-form compressive strength which facilitates handling;

- easily processed remotely;

- flexible, can be modified for particular waste-form.

Ordinary portland cement (OPC) is the most common type of cement used for immobilizing liquid and wet solid wastes worldwide. Several OPC-based mixtures are currently used to improve the characteristics of waste-forms and overcome the incompatibility problems associated with the chemical composition of certain types of radioactive waste. Composite cement systems may substitute pozzolan materials such as blast furnace slag (BFS) and pulverised fuel ash (PFA) for a portion of the OPC for cost 
reduction, energy saving, and potentially superior long-term performance. As well as the wasteform matrix, OPCs will be used in structural components of any repository (such as walls and floors) and are potential backfill materials. Consequently, an understanding of their durability in an underground environment even without waste is important.

Composite cements are used in the UK for $\amalg W$ encapsulation. BNFL uses a 9:1 ratio of BFS:OPC to reduce heats of hydration which would otherwise limit container volumes. Large containers (e.g., $500 \mathrm{~L}$ drums) can therefore be safely used without concern of over whether heating from setting reactions would cause water to boil off. Sellafield cements the cladding hulls waste by first determining the radionuclide inventory then metering the hulls into a drum with cement comprised of ordinary portland cement (OPC), blast furnace slag (BFS), and water formulated to meet processability and product quality constraints (Lewis and Barlow 1991). The $500 \mathrm{~L}$ drum is vibrated as hulls and cement are added to reduce void space and ensure adequate encapsulation of individual pieces.

Waste-cement mixtures may be prepared either directly in the container (in-drum mixing) which is the final product container, or prior to pouring into the container (in-line mixing). After in-drum mixing, the cement-waste mixture is allowed to set, the container is capped with a different composition cement to minimize void spaces and to avoid surface contamination, and a lid is fitted. A simplified process flow diagram for a cement in-drum system is shown in Figure 4.2.

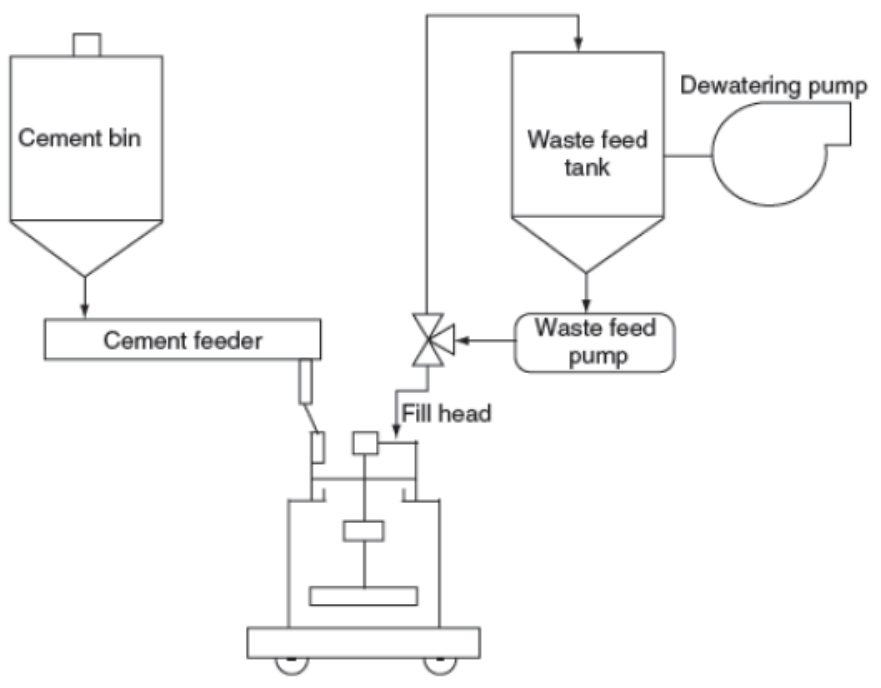

Figure 4.2. Schematic of In-drum Mixing (Ojovan and Lee 2005)

A reusable mixer may be used and removed before the container is capped and the mixture sets or a disposable mixer may be used and left in the container. The latter is referred to as the lost paddle approach and involves the use of a paddle that is inexpensive to fabricate but capable of producing a homogeneous mix. A disadvantage of a reusable mixer is that the residue on the mixing paddle must be removed and the paddle washed to prevent area and container contamination. Tumble mixing is a cementation process that does not use mixing paddles. In-line mixing processes combine the waste, any additives, water and cement before they are placed into a disposal container. In this process, the cement and the waste are separately metered into the mixer. The cement is fed by a screw feeder, while the waste is fed by a positive displacement pump. The cement-waste mix is released directly from the mixer into the container. The level of cement/waste in the container is monitored, possibly by ultrasonic or contact probes. The container is then sealed, decontaminated, monitored and sent for storage. The waste tank and mixer can be flushed through after each run. If desired, the rinsing water can be stored and used to 
prepare the feed slurry for the next run. In-line type cementing facilities use different types of mixer such as mechanical, hydraulic and small volume vortex induction mixers. Figure 4.3 shows examples of waste encapsulated via in-line cementation at the BNFL waste encapsulation plant at Sellafield, UK.

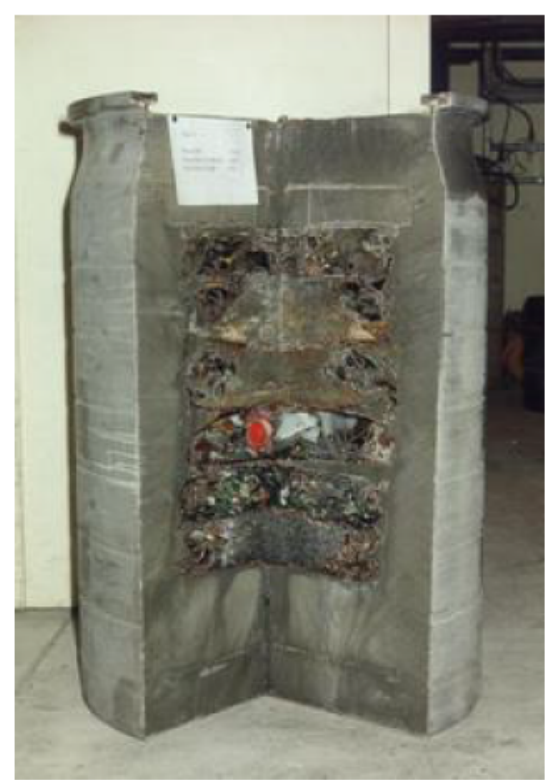

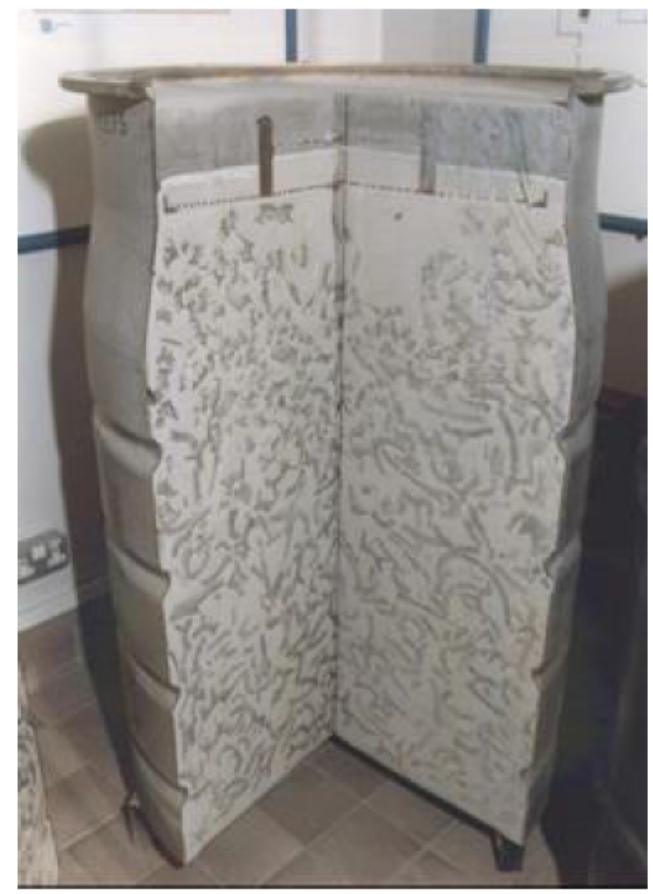

(b)

(a)

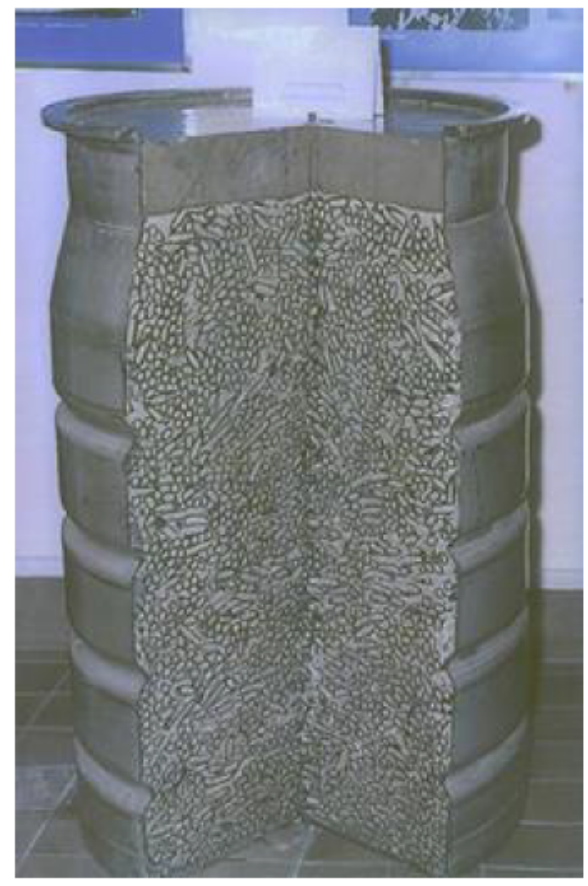

(c)

Figure 4.3. Examples of Composite Cement Waste Forms Fabricated at Sellafield. Waste in (a) is Compacted ILW Solids, in (b) is Magnox (Mg Alloy) Fuel Cladding Swarf and in (c) is Zircaloy Cladding Hulls from UOX Fuel

Operating cementation facilities are complex in design and operation, as they include a number of additional important technological operations to ensure reliable immobilization and final product quality. Additional vibration of drums enables void filling and use of dense cement pastes. Various additives are 
used to enhance workability and increase waste loading. For example, vermiculite, bentonite, clinoptilolite and shales enhance radionuclide retention enabling immobilization of specific waste streams by cementation.

\subsubsection{Super Compaction}

Super-compaction of hulls and hardware was a process developed jointly by France and Germany in the 1980's and 1990's. AREVA adopted super-compaction of metal wastes at the LaHague UP2-800 and UP3 plants using a process called Atelier de Compactage des Coques (ACC). The ACC began full operation in 2002 at the La Hague facility. The ACC process reduced the packaged volume of hulls, hardware and metallic technical wastes by a factor of 4 compared to the cementation process previously employed.

In this process, hulls and hardware are removed from the continuous dissolver and washed. Washed metal is loaded wet into $1-\mathrm{m}$ diameter $\times 1.5-\mathrm{m}$ tall drums and stored until processed at ACC. Drums of hulls in water are analysed for materials control and accountability (MC\&A) before being loaded into the separator that initially separates hulls from end pieces and then loads them into an $80-\mathrm{L}$ can. The separator consists of two concentric rotating coils. The first is very coarse and collects the end pieces while the second is fine and collects the hulls. They move the respective materials to the end of the coil and meter them into a can in the appropriate order with hulls surrounding the end pieces for effective compaction. The dimensions of the 80-L can are roughly 2 feet tall and 2 inches less than the diameter of the UC-C standard can (which is 1.4 feet). The can is dried at $\sim 200^{\circ} \mathrm{C}$ in $\mathrm{N}_{2}$ flowing through a port in the can bottom to a $-26^{\circ} \mathrm{C}$ dew point. It is sealed and pressed under $\mathrm{N}_{2}$ atmosphere in a $2500 \mathrm{t}$ uniaxial press die at $200 \mathrm{MPa}$ (see Figure 4.4a). The resulting pucks (see Figure 4.4b) are placed on a turn table and selected based on height and fissile content $(<300 \mathrm{~g}$ fissile per container) for loading into a UC-C. The UC-C has a corrugation on the inside that holds the pucks in place and aligned (see Figure 4.4c). The UC-C is welded and measured for MC\&A. The pucks are roughly $65 \%$ dense and the can is filled to roughly $95 \%$ of the volume.

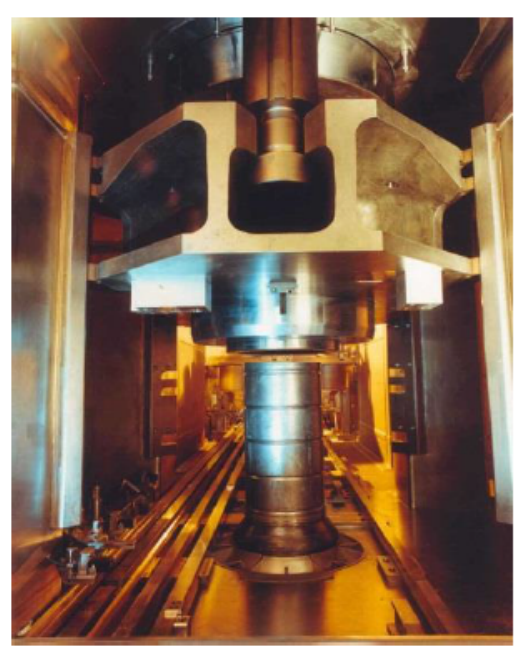

(a)

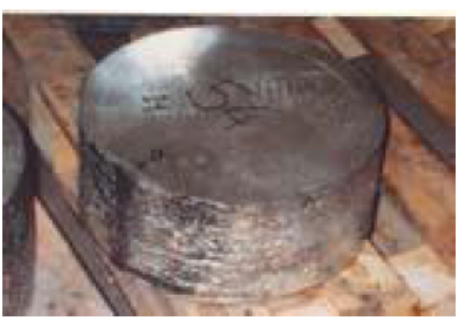

(b)

Figure 4.4. Example Metal Waste Form (a) Compaction Unit, (b) Puck, and (c) Cross-section of UC-C Canister (Courtesy of AREVA)

The corrosion of metallic hulls and stainless steel hardware was investigated by the Agence Nationale Pour la Gestion des Déchets Radioactifs (ANDRA), concluding (ANDRA 2005): 
"... the total release of radionuclides would take place over 15,000 years in the case of inconel, 70,000 years in the case of stainless steel and approximately 100,000 years in the case of Zircaloy cladding..."

\subsection{Metal Melting}

As described in Section 6, melting has been proposed for both zirconium and SS hulls treated by electrochemical processing. The same process is applicable to hulls from aqesous reprocessing and won't be repeated here.

Others have investigated melting of hulls, either directly (Perthier and Al. 1994) or with lower temperature melting elements (Mazoyer and Vernaz 1986). Berthier et al. melted the hulls using a $(\mathrm{Ca}, \mathrm{Ba}) \mathrm{F}_{2}$ flux in a cold crucible melter (Berthier et al. 1994). Mazoyer and Vernaz melted a eutectic composition of $21.5 \mathrm{Cu}$ mole $\%$ and $78.5 \mathrm{~mole} \% \mathrm{Zr}$ at $1150^{\circ} \mathrm{C}$ and embedded the resulting alloy in glass (Mazoyer and Vernaz 1986).

\subsubsection{Reactive Gas Purification of $\mathrm{Zr}$}

Recycle of the nuclear grade $\mathrm{Zr}$ has the potential to significantly reduce the UNF waste components that require emplacement in a geologic repository. For example, the reference reprocessing facility would produce more compacted hulls/hardware canisters than HLW glass canisters (Areva 2012). If $\mathrm{Zr}$ were removed and the residue reintroduced into the dissolver or HLW glass, 50\% fewer canisters would be produced for the same amount of fuel processed (assuming hardware and metallic technological wastes still produce $\sim 15 \%$ of the canisters). For the process to be successful, the recovered zirconium product must contain radionuclide concentrations that are inconsequential to the use of zirconium in future nuclear applications, recognizing that the recovered zirconium will inherently contain one radioactive isotope, ${ }^{93} \mathrm{Zr}$, which has a half-life of $\sim 1.5$ million years and a weak beta emission. At a minimum, the recovered zirconium must meet specifications for disposal as LLW.

Reactive gas processes were tested for chemically decladding fuel including chlorination and hydrochlorination (Zircex) (Bond et al. 1992). A "Hot-Wire" or "Crystal Bar" iodization process was operated at Western Zirconium for natural Zr purification from 1982-1991 (Van Arkel and De Boer 1925). More recently, Collins further tested the reactive gas processes to purify $\mathrm{Zr}$ from irradiated fuel hulls (Collins et al. 2010, 2012, 2014). They tested $\mathrm{I}_{2}, \mathrm{Cl}_{2}$, and $\mathrm{HCl}$ processes according to:

$$
\begin{gathered}
\text { clad }+2 \mathrm{I}_{2}(\mathrm{~g}) \stackrel{350^{\circ} \mathrm{C}}{\longrightarrow} \mathrm{ZrI}_{4}(\mathrm{~g})+\text { ash }:: \mathrm{ZrI}_{4}(\mathrm{~g}) \stackrel{1500^{\circ} \mathrm{C}}{\longrightarrow} \mathrm{Zr}(\mathrm{s})+2 \mathrm{I}_{2}(\mathrm{~g}) \\
\operatorname{clad}+2 \mathrm{Cl}_{2}(\mathrm{~g}) \stackrel{350^{\circ} \mathrm{C}}{\longrightarrow} \mathrm{ZrCl}_{4}(\mathrm{~g})+\text { ash }:: \mathrm{ZrCl}_{4}(\mathrm{~g}) \stackrel{150^{\circ} \mathrm{C}}{\longrightarrow} \mathrm{ZrCl}_{4}(\mathrm{~s}) \\
\mathrm{clad}+4 \mathrm{HCl}(\mathrm{g}) \stackrel{350^{\circ} \mathrm{C}}{\longrightarrow} \mathrm{ZrCl}_{4}(\mathrm{~g})+2 \mathrm{H}_{2}(\mathrm{~g})+\mathrm{ash}:: \mathrm{ZrCl}_{4}(\mathrm{~g}) \stackrel{150^{\circ} \mathrm{C}}{\longrightarrow} \mathrm{ZrCl}_{4}(\mathrm{~s})
\end{gathered}
$$

The product of these reactions is either $\mathrm{Zr}$ metal or solid $\mathrm{ZrCl}_{4}$. The solid $\mathrm{ZrCl}_{4}$ is a direct input to the $\mathrm{Zr}$ hulls manufacturing process. These three processes were evaluated both experimentally and through process modelling and it was concluded that the direct chlorination process was the most promising (Collins et al. 2012). 
The chlorination process (Figure 4.5) is based on the formation of volatile zirconium tetrachloride salt at $>350{ }^{\circ} \mathrm{C}$, followed by sublimation (volatilization) of the salt to condensers where it condenses to an intermediate product.

The product salt will likely require further purification to remove volatile and entrained impurities. A reducing atmosphere $\left(\mathrm{N}_{2} / \mathrm{H}_{2}\right)$ may be necessary for the purification treatment to prevent volatilization of impurities.

The non-volatile impurities, primarily zirconia but including traces of radioactive fuel components, would remain in the salt formation reactor and be removed as ash. Treatment of the ash (likely with $\mathrm{NO}_{2}$ or electrochemically) would be required to convert any non-volatile chloride salts to nitrate salts and remove residual chlorine. This would be necessary to allow the ash to be further treated in the separations process without excessive corrosion of the separations and waste treatment equipment. The dechlorinated ash would be dissolved in the dissolver along with fresh fuel.

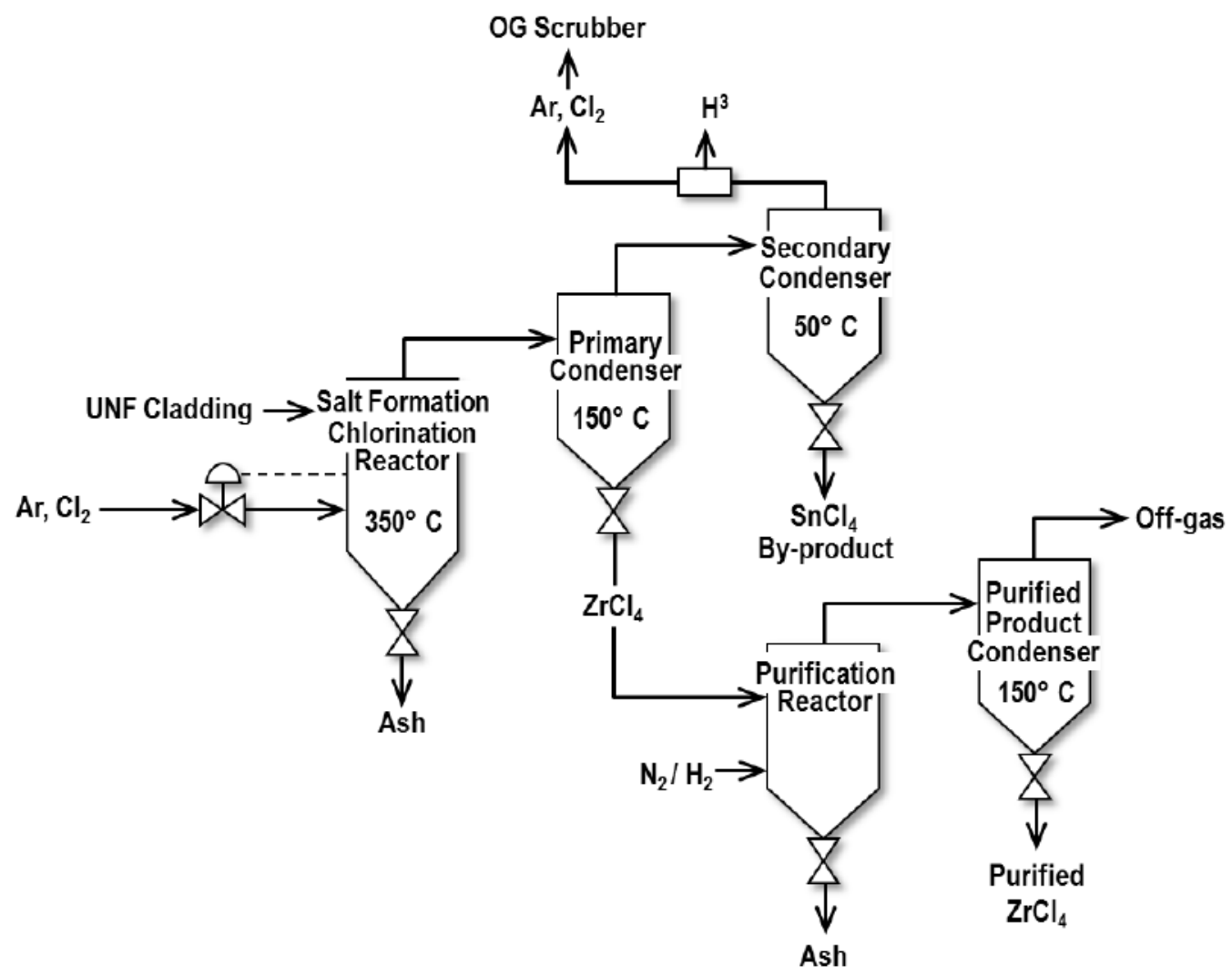

Figure 4.5. Process Flow Diagram for Zirconium Recovery Chlorination Process.

Chemical impurities that require removal for reuse in nuclear fuel cladding include TRU and FP, alloying elements ( $\mathrm{Sn}, \mathrm{Nb}, \mathrm{Fe}, \mathrm{Ni}$, and $\mathrm{Cr}$ ), and non-metals, such as $\mathrm{N}, \mathrm{O}$, and $\mathrm{C}$. Methods and strategies need to be developed to capture any volatile radioactive contaminants that are not easily condensed, such as tritium, from the off-gas stream and to disposition these materials as well as the non-volatile "ash". Industrial-scale processes are used to purify zirconium from ores, convert it to zirconium tetrachloride salt, and then convert the salt to a purified zirconium metal "sponge" (Figure 4.6). The recycled zirconium tetrachloride recovered from UNF cladding can be converted to metal sponge by the same process (Figure 4.6). Alloying agents are added and a series of metallurgical processes (heating, 
extruding, rolling, and milling with intermittent annealing steps) are used to fabricate Zircaloy fuel cladding tubes.

Although technical challenges remain, the process shows promise and should be developed further. The nuclear grade $\mathrm{Zr}$ generated from this process will contain roughly $0.03 \%{ }^{93} \mathrm{Zr}$ (a low energy $\beta$ with a $1.5 \times 10^{6} \mathrm{y}$ half-life) and some level of other radioactive impurites and so will likely require a separate forming and product line.

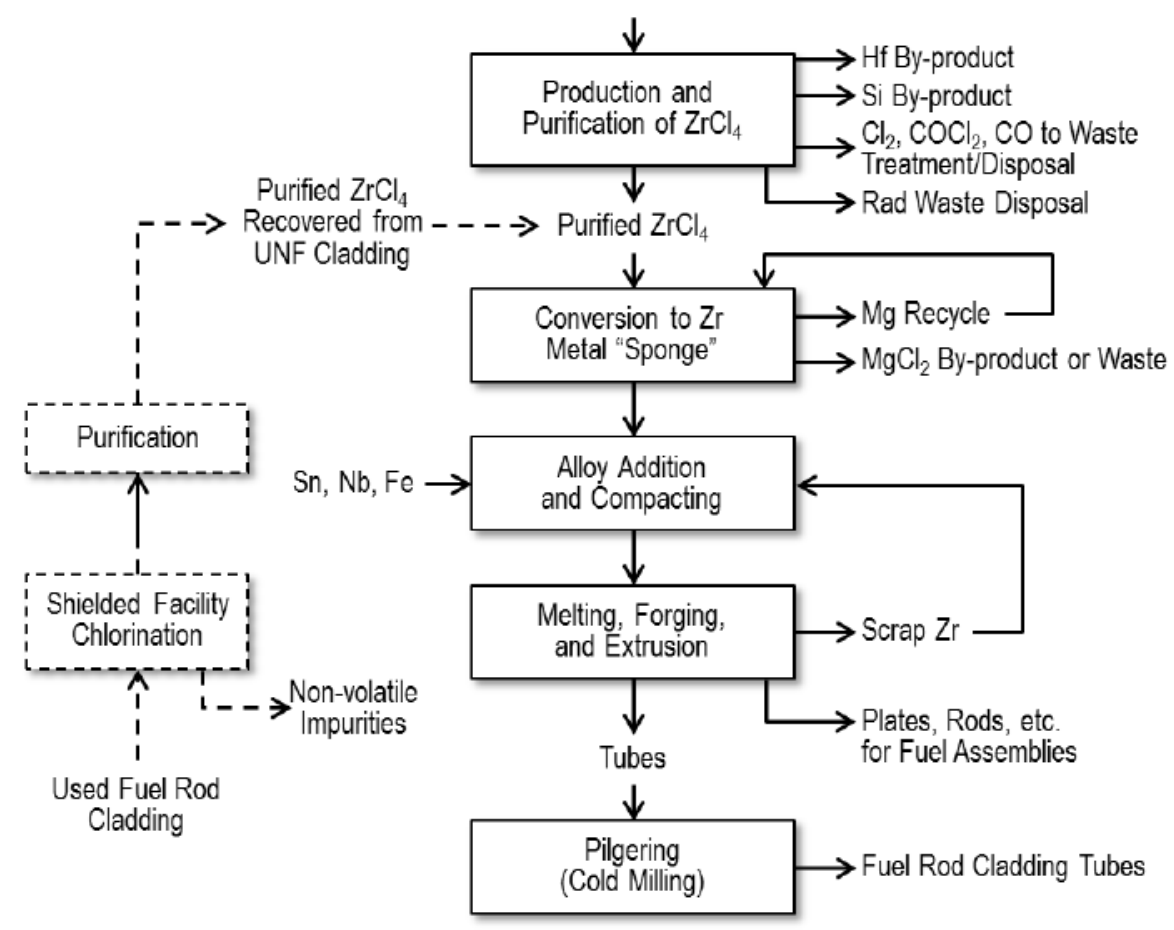

Figure 4.6. Potential Insertion of Purified Recycle Zirconium Tetrachloride into the Process for Zirconium Alloy Cladding Manufacture.

\subsection{Hulls and Hardware Management Recommendation}

The most mature technology for hulls and hardware management are cementation and super-compaction. Both are low temperature processes with significant industrial experience. While cementation increases the waste form volume and may significantly limit disposal options (due to the impact of cement on disposal facility $\mathrm{pH}$ and chemistry), super-compaction reduces the volume (estimated $4 \times$ reduction compared to cementation). It is therefore recommended that super-compaction of the combined hulls and hardware stream as the reference technology. The resulting waste would be placed in canisters for deep geologic disposal.

Zirconium purification by chlorination has the potential to significantly reduce the disposal load of highly radioactive wastes from reprocessing and should be further developed. A roadmap of testing activities was completed by Collins et al. (2012b) and should be followed. 


\subsection{Data Gaps and Research Needs}

- Develop and demonstrate a process for reactive gas separation of $\mathrm{Zr}$ for recycle or LLW management.

- Develop and demonstrate a method for managing the chlorinated ash from reactive gas $\mathrm{Zr}$ purification. It's been proposed that the ash would be treated to remove the chloride and returned to the dissolved fuel stream.

- Determine fate of residual ${ }^{3} \mathrm{H}$ in cladding, determine the ability to remove tritium from the cladding during the chlorination process, and evaluate the capture and disposal of ${ }^{3} \mathrm{HCl}$ after $\mathrm{Zr}$ purification. In industrial production of chlorine, $\mathrm{HCl}$ is removed from gas streams by water washing. $\mathrm{HCl}$ is highly soluble in water but chlorine is not. The wet chlorine is then dried with sulfuric acid. It may be possible to use a molecular sieve in place of sulfuric acid to dry the $\mathrm{Cl}$ stream. This has not been demonstrated. Once the water becomes concentrated in $\mathrm{HCl}\left({ }^{3} \mathrm{H}\right)$, it could be grouted (or neutralized and grouted).

- Determine the performance characteristics of the compacted hulls, generate and parameterize a long-term corrosion model, and develop a waste form compliance plan. 


\section{ELECTROCHEMICAL SALT HLW}

\subsection{Glass-Bonded Sodalite}

The glass-bonded sodalite waste form - usually referred to as the ceramic waste form (CWF) - that was developed to immobilize high-level radioactive waste salts generated during the electrometallurgical treatment of spent sodium-bonded nuclear fuel utilizes sodalite to contain $\mathrm{NaCl}$ from the waste salt and borosilicate glass to encapsulate that sodalite in a physically durable monolithic waste form (Pereira et al. 1999, Simpson et al. 2001). Zeolite-4A is used to occlude the waste salt that is the working fluid in the Echem process. The zeolite with the occluded salt is mixed with a low melting temperature glass and heated to a temperature at which the salt-loaded zeolite first converts to sodalite then becomes encapsulated in a glass matrix. This product is specific to the chloride salts generated during Echem processing of fuel, but, could be used for a number of the wastes generated from salt processing described in Section 1.2.1.

The glass phase serves three important purposes in the waste form: (1) it encapsulates the micron-sized lanthanide and actinide oxides that are produced during the occlusion step (when the salt is contacted by small amounts of residual water in the zeolite) and the halite inclusions that form during waste form processing; (2) Na from the glass is exchanged with other alkali metal and alkaline earth cations in the salt (most importantly fission products) allowing their incorporation in the glass phase; and (3) the glass provides additional Na to sequester excess chloride as sodalite or halite. The glass phase provides the chemical durability that controls the release of both radionuclides that are dissolved in the glass and radionuclides in phases that are encapsulated by the glass. The primary role of the sodalite phase in the waste form is to host the chloride so the radionuclide cations can dissolve in the glass; iodide is the only radionuclide contained in the sodalite and halide phases.

\subsubsection{Zeolite Salt Occlusion}

The CWF is produced when waste salt from the electrorefiner that contains fission products is combined with (occluded in the pores of) zeolite $4 \mathrm{~A}\left[\mathrm{Na}_{12}\left(\mathrm{AlSiO}_{4}\right)_{12}\right.$, on a dry basis]. The salt-occluded zeolite (SLZ) is then mixed with borosilicate glass frit and consolidated in an electric furnace. The zeolite reacts with the $\mathrm{NaCl}$ in the waste salt to form sodalite according to the reaction:

$$
\underset{\text { zeolite } 4 \mathrm{~A}}{\mathrm{Na}_{12}\left(\mathrm{AlSiO}_{4}\right)_{12}}+\underset{\text { halite }}{4 \mathrm{NaCl}} \rightarrow \underset{\text { sodalite }}{2 \mathrm{Na}_{8}\left(\mathrm{AlSiO}_{4}\right)_{6} \mathrm{Cl}_{2}}
$$

The production of sodalite is a stoichiometrically related to the amounts of zeolite $4 \mathrm{~A}$ and halite in the salt. The sodalite phase hosts the chloride (and iodide) in the waste form, whereas the radionuclide cations in the salt waste replace $\mathrm{Na}^{+}$in the glass to maintain charge balance. Iodide, as a halogen like chlorine, can substitute for chloride and is the only radionuclide contained in the sodalite in significant quantity.

One option being considered is the draw-down of lanthanides from the salt waste and inclusion of those lanthanides in the CWF. The metal granules contained in the salt from LN-drawdown process. The incorporation of lanthanide metals in the CWF has not been fully developed or tested, but conceptually they can be added to the occlusion process. The misch metal particles would then be oxidized during the salt occlusion process by residual water in the zeolite, as are actinide and rare earth chlorides in the waste salt. 


\subsubsection{Glass Encapsulation}

The borosilicate glass (a) encapsulates sodalite and $\mathrm{NaCl}$ (halite) inclusions in a physically durable monolithic waste form, (b) encapsulates the micron-sized lanthanide and actinide oxides that are produced during the occlusion step (the lanthanide and actinide chlorides react with small amounts of residual water in the zeolite), (c) provides $\mathrm{Na}$ from the glass for exchange with other alkali metal and alkaline earth cations in the salt (most importantly the fission products), allowing their incorporation in the glass phase, and (d) provides additional $\mathrm{Na}$ to supplement the amount of $\mathrm{Na}$ present in the salt waste to sequester excess chloride as sodalite or halite. The glass phase provides the chemical durability that controls the release of radionuclides that are either dissolved in the glass or in oxide phases that are encapsulated by the glass.

\subsubsection{Excess Halite Inclusions}

The formation of nepheline during CWF production decreases the amounts of sodalite formed and waste salt immobilized. A small amount of $\mathrm{NaCl}$ in excess of that needed to form sodalite during waste form production is desirable to minimize sodalite decomposition to nepheline according to:

$$
\begin{array}{ccc}
\mathrm{Na}_{8}\left(\mathrm{AlSiO}_{4}\right)_{6} \mathrm{Cl}_{2} \leftrightarrow & 2 \mathrm{NaCl}+1.5 \mathrm{Na}_{4}\left(\mathrm{AlSiO}_{4}\right)_{4} \\
\text { Sodalite } & \text { Halite Nepheline }
\end{array}
$$

Excess $\mathrm{NaCl}$ forms halite inclusions in the waste form that are distributed throughout the glass phase. Small amounts of halite inclusions are not detrimental to the chemical durability of the glass phase because they do not affect the glass composition or the performance of the waste form. Halite inclusions do dissolve quickly when contacted by water, and increase the surface area that becomes exposed to groundwater during glass degradation, but this is a minor effect. When the CWF is properly formulated, the halite does not contain significant amounts of radionuclides except for iodine. In-order to gain access to the inclusions, water must first dissolve the encapsulating glass phase. In terms of waste form performance, the release of $\mathrm{I}^{-}$from halite inclusions is equivalent to the release of $\mathrm{I}^{-}$from the glass that dissolved to expose the inclusions. Tolerating a small amount of halite inclusions would accept a minor decrease in waste form durability to gain a large benefit of waste loadings to be increased from roughly $8 \%$ to $12 \%$ for a minor (Ebert 2010 ).

\subsubsection{Waste Loading}

The loading of radionuclides in the waste form depends on the concentration of radionuclides in the salt, the concentration of salt in the waste form, and any addition of elemental lanthanides that might be separated from the salt to enable salt purification and recycle and then added back to the waste stream prior to waste form processing. ${ }^{\mathrm{g}}$ The salt waste loading is limited primarily by (a) the chloride content of the salt, and secondarily by (b) the Na content of the salt, (c) the Na content of the glass, needed for ion exchange with other cations in the salt, and (d) the amount of glass needed to encapsulate the sodalite and accommodate inclusion phases formed during processing (halite and mixed oxides of lanthanides and actinides). For salts with high concentrations of heat-generating isotopes (e.g., ${ }^{90} \mathrm{Sr},{ }^{134} \mathrm{Cs}$, and ${ }^{137} \mathrm{Cs}$ ), waste loading may be limited by the thermal stability of the CWF or heat limits imposed by the storage and disposal systems. An initial evaluation of CWF for electrochemical salts showed that the maximum centerline temperature for the baseline 20.5 inch diameter canister was $329^{\circ} \mathrm{C}$, well below the CWF stability temperature. Less-than-maximum waste loadings may be desired to manage heat during waste form storage and disposal activities.

$\mathrm{g}$ The concentration of radionuclides and the concentration of salt in the waste form provide alternative definitions of the waste loading. 
The overall salt loading of 8 mass\% in the CWF from Experimental Breeder Reactor-II (EBR-II) UNF reprocessing was a conservatively low administrative limit based on the desire to minimize the amount of halite formed. It is now known that additional halite is not detrimental to performance, and that acceptable waste forms can likely be made with higher salt loadings (Ebert 2010). These higher salt loadings require Na to be provided by the glass, and if that is still not sufficient, from additional sources of $\mathrm{Na}$.

The waste loading is usually limited by the amount of $\mathrm{Na}$ available in the salt and in the glass, or added to the system to generate enough sodalite and halite to accommodate chloride in the salt. Other alkali metals in the salt are not effective in generating sodalite and instead exchange with $\mathrm{Na}$ in the glass or react form other phases (e.g., Cs-pollucite, Sr-celsian, Li-aluminosilicate). The Na released from the glass into the salt is available for sodalite and halite formation. The Na content of the glass must be adequate to accommodate the exchanges with other cations in the salt (unless another phase is formed or unless Na is added from another source). The glass may become totally depleted of Na during waste form processing (Frank 2004; O'Holleran 1999). This will halt sodalite production and the incorporation of waste salt into the CWF.

Waste forms can be formulated utilizing other mineral phases to accommodate cations in the salt that exceed solubilities in the glass and limit the salt waste loading. For example, pollucite and celsian can be used to accommodate $\mathrm{Cs}$ and $\mathrm{Sr}$ and avoid unacceptably large amounts of radionuclide-bearing salt being distributed throughout the waste form (Ebert 2010).

\subsubsection{Thermal Loading}

The impact of self-heating of the CWF is estimated using a previous study of the effects of heat treatment on the phase composition and chemical durability to evaluate the impact of production upsets (Ebert et al. 2005). Two CWF products made with reference salt and glass contents were subjected to heat treatments at 400 and $500{ }^{\circ} \mathrm{C}$ for durations up to 1 year, and at $600,700,800$, and $850^{\circ} \mathrm{C}$ for durations up to $100 \mathrm{~h}$. The CWF had been produced at $915^{\circ} \mathrm{C}$, so the higher temperatures certainly exceed the $\mathrm{T}_{\mathrm{g}}$ of the binder glass, although the value of $\mathrm{T}_{\mathrm{g}}$ was not known.

Heating at the highest temperatures had only a small effect on the crystalline phase composition; the amount of halite increased to as much as 3.7 mass\%, and nepheline was detected in samples treated at 800 and $850^{\circ} \mathrm{C}$. This suggested that a small fraction of the sodalite decomposed to form nepheline at these temperatures.

The effects of the heat treatments on the durability of the glass phases of CWF samples were determined using product consistency tests (PCTs). The releases of $\mathrm{Cl}, \mathrm{B}, \mathrm{Na}$, and $\mathrm{Si}$ in the PCTs were not affected by the heat-treatment conditions. The long-term effects of self-heating on the physical and chemical stability of the CWF are, therefore, considered to be negligible.

\subsubsection{Ceramic Waste Form Process}

The cost for the CWF fabrication process was estimated on the same basis of $\$ 5.4 \mathrm{M}$ per $15 \times 15 \mathrm{ft}$ hot cell work area described above. The EBR-II salt management process flowsheet was used to estimate the space and equipment needs for CWF fabrication (Bateman et al. 2007; Morrison and Bateman 2010; Morrison et al. 2010; Priebe and Bateman 2008; Simpson et al. 2001).

Salt will be crushed to roughly $10-\mathrm{mm}$ diameter particles in a jaw crusher. This operation was demonstrated to effectively crush a 7-cm diameter rod of salt in seconds. The crushed salt is then ground to $<250 \mu \mathrm{m}$ diameter particles. Roughly $10 \mathrm{~kg}$ of ground salt is then loaded into a V-blender with an appropriate amount of dried and ground (45-250 $\mu \mathrm{m}$ diameter) zeolite $4 \mathrm{~A}$ at a ratio of $\sim 70 \mathrm{~kg}$ zeolite/10 
$\mathrm{kg}$ salt. The mixture of materials is heated to $\sim 500{ }^{\circ} \mathrm{C}$ and mixed for $\sim 80 \mathrm{~h}$ to occlude the salt into the zeolite pore-structure. The batch is then cooled and the appropriate amount of glass frit is added $(\sim 27 \mathrm{~kg}$ glass frit/ $80 \mathrm{~kg} \mathrm{SLZ}$ ) and the batch is mixed for another hour at room temperature.

The blended batch of SLZ and glass is transferred to a sintering can comprised of three roughly $1-\mathrm{m}$ segments that are roughly $0.52-\mathrm{m}$ in diameter, as shown in Figure 5.1. The three segments are used to accommodate the $\sim 2.5 \times$ volume reduction that occurs when the reactants form the CWF. The canister will have a segmented $6.35-\mathrm{cm}$ diameter lifting rod in the center that will become embedded in the CWF as it is made and consolidated in the bottom segment of the sintering can. Several batches of the SLZ/glass mixture ( $110 \mathrm{~kg}$ each) are loaded into the canister until a sufficient amount of material is obtained to fill the bottom segment with CWF $(\sim 455 \mathrm{~kg})$. A weighted cover plate is placed on the top of the batch and the three-segment canister is loaded into a sintering furnace. The batch is heated at 1 ${ }^{\circ} \mathrm{C} / \mathrm{min}$ to $500{ }^{\circ} \mathrm{C}$ and held for sufficient time $(\sim 60 \mathrm{~h})$ to equilibrate the temperature throughout the material before the frit begins to soften. In the next step, the batch is heated at $0.5^{\circ} \mathrm{C} / \mathrm{min}$ to $925^{\circ} \mathrm{C}$ and held at that temperature for sufficient time $(\sim 75 \mathrm{~h})$ to react all the components to form a glass-bonded sodalite waste form in the bottom segment having a density within $10 \%$ of the theoretical density, which is $2340 \mathrm{~kg} / \mathrm{m}^{3}$. The final step is the controlled cool down which is optimized to avoid cracking of the $\mathrm{CWF}$ while maintaining the total furnace time of $250 \mathrm{~h}$. The canister is removed from the furnace and the top two segments of the sintering can are removed remotely. Only the bottom portion containing the CWF will be disposed, while the top two portions are reused for the next batch (each segment advancing down in the stack of three segments). The weight is removed from the bottom segment containing the CWF, but the plate is left in the can as a spacer between successive CWF products that will be placed in a disposal canister. Four 1.09-m-tall segments (containing $1.01 \mathrm{~m}$ of CWF) are placed in a 4.4-m-tall disposal canister. Each sintering can segment with CWF is attached to the segment below it by a Jgroove fitting in the sintering can. The outer canister is welded closed and transferred to a canister storage building until shipment to a geologic repository for disposal.

Although the 20.5 -inch $(0.52 \mathrm{~m})$ diameter canister was used as a reference in this study, smaller canisters appropriate for deep borehole disposal (e.g., $8.5 \mathrm{inch}$ ) are also possible. The heating cycle time is expected to reduce with the square of canister diameter (Bateman and Solbrig 2006). 


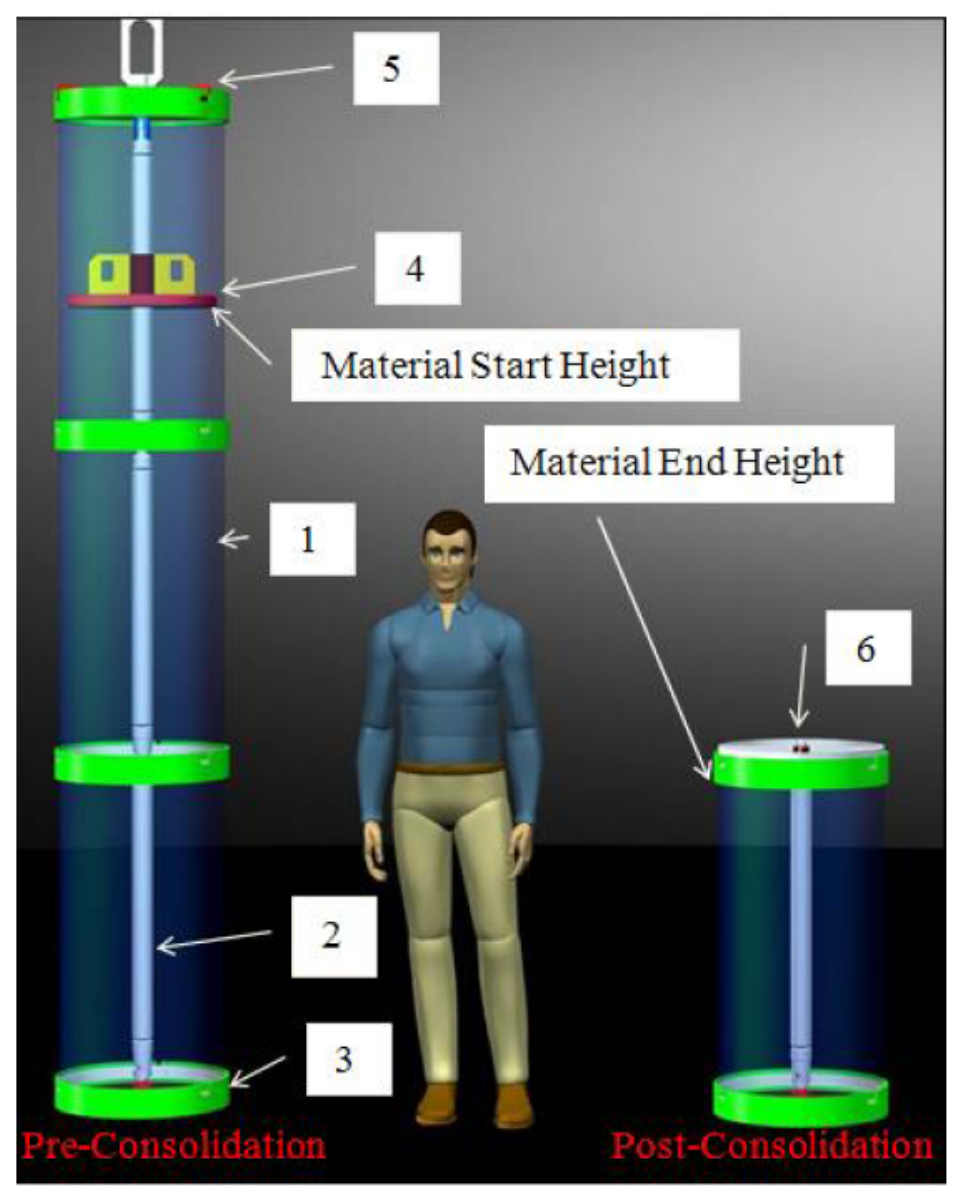

Figure 5.1. Rendered Model of the CWF Container, from Morrison et al. (2010)

\subsubsection{Mass and Volume Estimates}

The total mass and volume of CWF generated during fuel processing is strongly dependent on the fraction of eutectic $(\mathrm{Li}, \mathrm{K}) \mathrm{Cl}$ salt that is immobilized with the fission products and sodium chlorides. Simpson (2013) evaluated factors affecting the amount of waste form produced from electrochemical reprocessing of metal SFR UNF and concluded that the key variable affecting the amount of salt waste form was the fission product concentration limit for processing.

He commented that the ultimate concentration of fission products and sodium in the salt "...could be based upon the liquidus temperature of the salt, heat from decay, or contamination of actinide products..." A convenient measure for this limit is the "impurity content," which is effectively the combined concentrations of fission product and sodium chlorides in the salt at time of immobilization. Two options are available. Either fuel can be processed until the impurity content limit is reached and the salt is disposed or the separations processes can be used to concentrate the impurities in a small amount of salt that is dispose and recycle the purified salt back to the electrorefiner. An evaluation of the impact of the impurity content of the salt when it is removed from the electrorefiner for treatment on the cost of waste form fabrication, storage, and disposal showed that the overall cost decreases linearly with the impurity content until an impurity content near 55 mass $\%$ is reached, at which point the cost levels off to roughly a constant value established by the need to manage the decay heat in the disposal system (Figure 5.2). This represents a waste salt composed of 55 mass $\%$ fission product and sodium chlorides and 45 mass\% eutectic salt. Using the data from Gutknecht (2012), the impact of impurity content on the 
liquidus temperature $\left(T_{L}\right)$ of the salt was estimated. The salt $T_{L}$ reaches the nominal ER operating temperature of $500^{\circ} \mathrm{C}$ at an impurity content of 53 mass $\%$. Therefore, salt waste form volume estimates assume all of the fission products and bond sodium processed with the cladding formed chloride salts and accumulated to $50 \mathrm{mass} \%$ in the salt before processing. This is only slightly lower than the impurity content giving the maximum cost benefit.

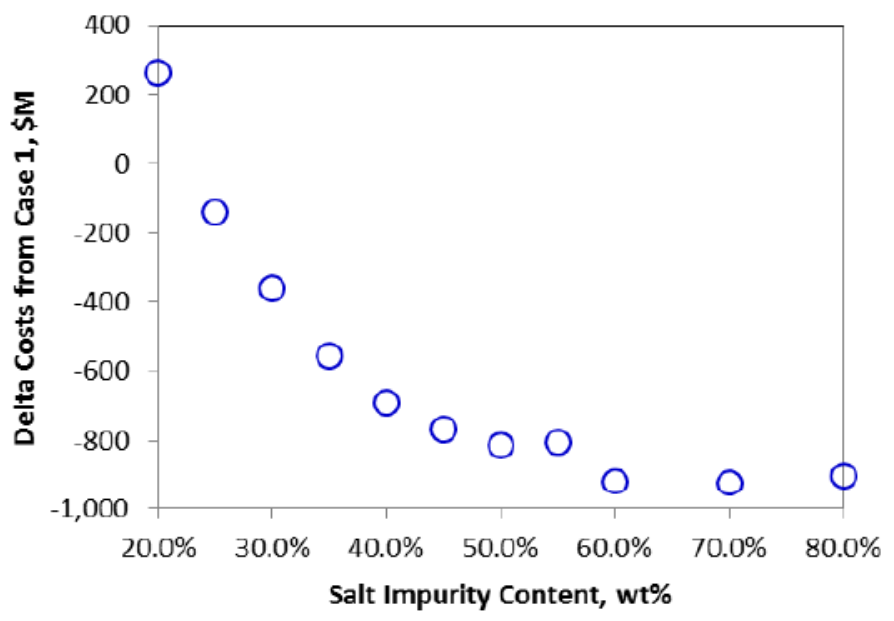

Figure 5.2. Example CWF Related Process Cost as a Function of Impurity Content (for a 20 tHM reprocessing plant)

A $20 \mathrm{tHM} / \mathrm{y}$ plant will produce $5,300 \mathrm{~kg}$ of waste salt comprised of $55.87 \mathrm{mass} \% \mathrm{Cl}$ for disposal annually. Table 5.1 lists the masses and volumes of CWF that would be produced with this salt for formulations with 20 and 25 mass\% borosilicate glass that allow for $0,2.5$, and 5 mass \% halite in the final waste forms.

Table 5.1. Ceramic Waste Form Mass and Volume for $20 \mathrm{tHM} / \mathrm{y}$ Reprocessing

\begin{tabular}{|c|c|c|c|c|c|c|}
\hline Case & 1 & 2 & 3 & 4 & 5 & 6 \\
\hline BSG, mass\% & 25 & 25 & 25 & 20 & 20 & 20 \\
\hline Halite, mass \% & 0 & 2.5 & 5 & 0 & 2.5 & 5 \\
\hline CWF Mass, kg/y & 54,000 & 43,600 & 36,400 & 50,700 & 41,300 & 34,800 \\
\hline Density, $\mathrm{kg} / \mathrm{m}^{3}$ & 2112 & 2109 & 2106 & 2104 & 2100 & 2097 \\
\hline CWF Volume, $\mathrm{m}^{3} / \mathrm{y}$ & 25.6 & 20.7 & 17.3 & 24.1 & 19.6 & 16.6 \\
\hline Number of canisters/y & 30.0 & 24.3 & 20.3 & 28.2 & 23.0 & 19.5 \\
\hline
\end{tabular}

\subsection{Alternative Waste Forms for Immobilization of Salt Processing Wastes}

Glass bonded sodalite is the baseline waste form for immobilization of the waste salts and radionuclides from the electrometallurgical treatment of spent sodium-bonded fuel. Tellurite glass and an alternative type of glass-bonded sodalite made with a solution-based process are being developed. These waste forms are discussed below. 


\subsubsection{Tellurite Glass}

Tellurite glasses were introduced in the 1950s by Stanworth (1952). They are of general interest in the glass community because of their potential as optoelectronic materials for fiber optics communications and optical devices. The glasses have low melting temperatures (in the range of 600 to $800{ }^{\circ} \mathrm{C}$ ), moderate glass transition temperatures $\left(300\right.$ to $400{ }^{\circ} \mathrm{C}$ ), and high densities relative to borosilicate glasses (because of the relatively heavy element composition). From a waste management perspective, tellurite glasses are attractive because of the relatively high solubility of mixed chlorides in the glass and a flexible glass network that can accommodate the fission products in the wastes.

Scoping tests were conducted with tellurite glasses with $\mathrm{PbO}, \mathrm{Al}_{2} \mathrm{O}_{3}+\mathrm{B}_{2} \mathrm{O}_{3}, \mathrm{WO}_{3}, \mathrm{P}_{2} \mathrm{O}_{5}$, and $\mathrm{ZnO}$ as possible network modifiers (Riley et al. 2012a). From those studies, a $\mathrm{TeO}_{2}-\mathrm{PbO}$ glass with a molar ratio $\mathrm{TeO}_{2} / \mathrm{PbO}$ of 4.96 in the Te-Pb-O- $X \mathrm{Cl}_{20}$ system (where $X$ includes alkali, alkaline earth, and lanthanide cations at a $20 \%$ fission products loading) was identified as potential host phase for immobilization of the salt wastes. In a subsequent study, waste loadings of as high as 14 mass\% salt waste were achieved before phase separation was observed in the glass (McCloy et al. 2013). The normalized release of Na in the PCT for a lead tellurite glass with 10 mass $\%$ salt was $0.478 \mathrm{~g} / \mathrm{m}^{2}$. ${ }^{\mathrm{h}}$ This compares with $6.81 \mathrm{~g} / \mathrm{m}^{2}$ for the EA reference glass used as a standard for HLW borosilicate glasses and $0.6 \mathrm{~g} / \mathrm{m}^{2}$ for the typical U.S. HLW glasses, and $0.89 \mathrm{~g} / \mathrm{m}^{2}$ for CWF made by pressureless consolidation (Ebert 2005). The Toxicity Characteristic Leaching Procedure (TCLP) was conducted to assess the ability of the 10 mass\% saltloaded lead tellurite glass to meet land disposal restrictions in 40 CFR 268. Leachate concentrations for $\mathrm{Ba}$ and $\mathrm{Pb}$ were 0.010 and $2.20 \mathrm{mg} / \mathrm{L}$. These values are below the EPA toxicity limits of $100 \mathrm{mg} / \mathrm{L}$ for Ba and $5 \mathrm{mg} / \mathrm{L}$ for $\mathrm{Pb}$.

\subsubsection{Solution-Based Approaches for Making Sodalite}

As described above, the glass-bonded sodalite waste form is fabricated by blending the waste salt with zeolite $4 \mathrm{~A}$, heating at $500{ }^{\circ} \mathrm{C}$, mixing in the borosilicate glass binder, and consolidating by heating at $915^{\circ} \mathrm{C}$ for several days. The resulting waste loading ranges from 7.5 to roughly 11 mass \% after the addition of the glass binder. Alternative fabrication methods are being explored to synthesize sodalite with a near-room temperature process using a solution-based approach. This approach was originally intended to provide an alternative processing route with a product similar to the baseline CWF. Within the context of this study, goals were to maximize the sodalite fraction (i.e., maximize waste loading), minimize the void space, and reduce the processing costs. Past work includes investigating organic silica sources, germania as a replacement for silica, various $\mathrm{Na}_{2} \mathrm{O}$ - and $\mathrm{Al}_{2} \mathrm{O}_{3}$-additives, and alternative sintering aids and sintering techniques.

Recently, a solution-based method to making high-density sodalite pellets has been investigated (Riley et al. 2012b, Lepry et al. 2013). Three solution-based formulations were evaluated to make sodalite with the same simulated $X \mathrm{Cl}_{20}$ salt. The formulations used gibbsite $\left(\mathrm{Al}(\mathrm{OH})_{3} ; \mathrm{SM}-1\right)$, sodium aluminate $\left(\mathrm{NaAlO}_{2}\right.$; SM-2), and metakaolin $\left(\mathrm{Al}_{2} \mathrm{Si}_{2} \mathrm{O}_{7} ; \mathrm{SM}-3\right)$ as the precursors for the sodalite fabrication according to the simplified equations:

SM-1 (gibbsite) process: $6 \mathrm{NaOH}+6 \mathrm{Al}(\mathrm{OH})_{3}+2 \mathrm{NaCl}+6 \mathrm{SiO}_{2} \rightarrow \mathrm{Na}_{8}\left(\mathrm{AlSiO}_{4}\right)_{6} \mathrm{Cl}_{2}+24 \mathrm{OH}^{-}$

SM-2 (sodium aluminate) process: $6 \mathrm{NaAlO}_{2}+2 \mathrm{NaCl}+6 \mathrm{SiO}_{2} \rightarrow \mathrm{Na}_{8}\left(\mathrm{AlSiO}_{4}\right)_{6} \mathrm{Cl}_{2}$

SM-3 (metakaolin) process: $6 \mathrm{NaOH}+3 \mathrm{Al}_{2} \mathrm{Si}_{2} \mathrm{O}_{7}+2 \mathrm{NaCl}+1.5 \mathrm{O}_{2} \rightarrow \mathrm{Na}_{8}\left(\mathrm{AlSiO}_{4}\right)_{6} \mathrm{Cl}_{2}+6 \mathrm{OH}^{-}$

The general process steps are:

h Note that the PCT was performed using a glass to solution mass ratio of 0.1 (per the ASTM procedure). Since this glass has roughly double the density compared to typical $\mathrm{HLW}$ glasses, the effective glass surface area-to-solution volume ratio would be roughly half that of a $\mathrm{HLW}$ glass. 
- prepare the precursor materials by dissolving in water or caustic solution as appropriate at $70^{\circ} \mathrm{C}$

- $\operatorname{mix}$ the precursor solution(s) with the waste salt at room temperature

- dry overnight at $105^{\circ} \mathrm{C}$

- grind to a powder and add a sintering aid as appropriate

- press the powder into pellets at room temperature

- fire the pellets at temperatures between 650 and $950{ }^{\circ} \mathrm{C}$

The resulting products are characterized with respect to density, porosity, mineralogy, surface area, and chemical durability using the PCT (Riley et al. 2012b, Lepry et al. 2013).

The results from this study showed that each formulation had advantages and disadvantages: the SM-3 material had modest densities and low sodalite production and the SM-2 materials had very high sodalite production and modestly high densities. The sodium aluminate precursor fabrication route appeared to be the most effective with some specimens consisting of pure sodalite. The densities were also high at $\sim 90 \%$ of theoretical.

\subsection{Data Gaps and Research Needs}

- What limits the useful life of ER salt is not currently understood. The highest priority is to develop a detailed understanding of the useful life of the salt through a combination of modeling and experiments. Once it is determined what limits the useful life, research can then be performed to optimize processing operation to utilize the salt to the greatest extent practical.

- The process for CWF fabrication includes multiple steps, significant operator time, and handling of fine particles of highly radioactive material. This process should be simplified by optimizing the process or developing new waste processes and/or waste forms.

- The loading of salt in the waste form is limited to between 7 and 12 mass\% (total salt). Waste forms that can accommodate higher waste loading with efficient processes and provide adequate chemical durability should be investigated and compared to the baseline process.

- Large scale non-radioactive and small scale radioactive tests should be performed on the optimized waste forms and processes.

- Durability models, data, and qualification approaches need to be developed for optimized waste form(s).

- Methods for obtaining the salt from the electrorefiner and crushing it for further processing are needed.

- Methods for managing the bond sodium in fuel pin plenums (that will contain sufficient quantity of iodine to require management as HLW) need to be devised and tested. 


\section{ELECTROCHEMICAL UNDISSOLVED SOLIDS AND HULLS}

A metal waste form was developed for management of UDS and hulls from Echem process (Abraham et al. 1996, McDeavitt et al. 1998, Abraham et al. 1999). Initial formulations were considered for steel and Zircaloy hulls based on production requirements and the Fe-Zr phase diagram shown in Figure 6.1. To make the waste form, the hulls and UDS are loaded into a graphite crucible which is placed in a furnace and melted under inert atmosphere at $\sim 1600{ }^{\circ} \mathrm{C}$ (McDeavitt et al. 1998). The ingot is cooled in the furnace and then transferred to a canister as shown in Figure 6.2. The line drawn at $1600^{\circ} \mathrm{C}$ on the phase diagram in Figure 6.1 indicates composition regions where alloy waste forms can be made with waste streams dominated by steel and Zircaloy cladding. Two nominal compositions that were demonstrated as part of the EBR-II waste form development are highlighted: $85 \mathrm{Fe}-15 \mathrm{Zr}$ and $8 \mathrm{Fe}-92 \mathrm{Zr}$ (Ebert 2005).

Metal waste form fabrication has been successfully demonstrated using the nominal iron rich formulation with two active metal ingots fabricated (Westphal et al. 2013). Waste form production is currently planned to continue.

Work proceeded to develop the SS-15Zr material for steel hulls. The metallic fuel to be treated contained about $10 \% \mathrm{Zr}$ that remained in the metal waste stream and additions of only small amounts of trim $\mathrm{Zr}$ were required to achive the eutectic composition. According to the $\mathrm{Fe}-\mathrm{Zr}$ phase diagram, the SS-15Zr feed was expected to solidify as two major phases: $\alpha-\mathrm{Fe}$ and $\mathrm{Zr}_{6} \mathrm{Fe}_{23}$ intermetallic. However, the presence other constituents in the steel hulls and waste and the kinetics controlling the formation of those phases result in a phase assemblage with additional intermetallics. The typical microstructure of a $316 \mathrm{SS}-15 \mathrm{Zr}$ alloy, shown in Figure 6.3a, is comprised of well-mixed domains of an iron solid solution similar to 316 (dark phase) and a $\mathrm{ZrFe}_{2}$-like intermetallic (light phase) with regions of high $\mathrm{U}$ content (lightest phase). Both phases contain significant amounts of other elements from the steel and waste stream. The iron solid solution phase is the host phase for Tc and the intermetallic is the host phase for U. The same constituent phases were formed in alloys made recently with HT-9 steel and less Zr and U to represent alloys for waste streams such a that given in Table 1.15. Alloys were made with $\mathrm{U}: \mathrm{Zr}$ mole ratios near $1: 1,1: 2$, and $3: 1$ to study the effect on the phases formed and waste form durability (Olson 2012). These waste forms are dominated by an iron solid solution phase having a composition very similar to HT-9 with Fe-Zr-U and Pd-Zr-U intermetallics distributed throughout the steel phase. For example, the microstructure of an alloy HT-9SS-2Zr-5U, which has a 1:1 mole ratio, is shown in Figure 6.3b. Note that the laboratory-sized waste forms were successfuly processed at $1650{ }^{\circ} \mathrm{C}$ for $1 \mathrm{~h}$ from a surrogate waste stream with 83 mass\% HT-9, 15\% noble metal waste, and only 2 mass $\% \mathrm{Zr}$. 


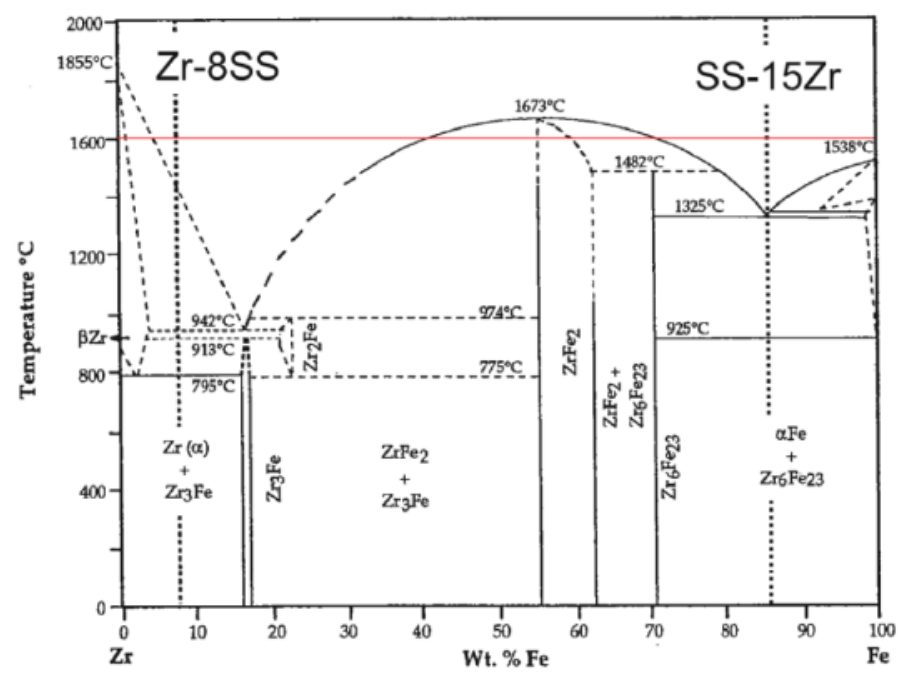

Figure 6.1. Zr-Fe Phase Diagram Based on (Arias 1988; McDeavitt et al. 1998)

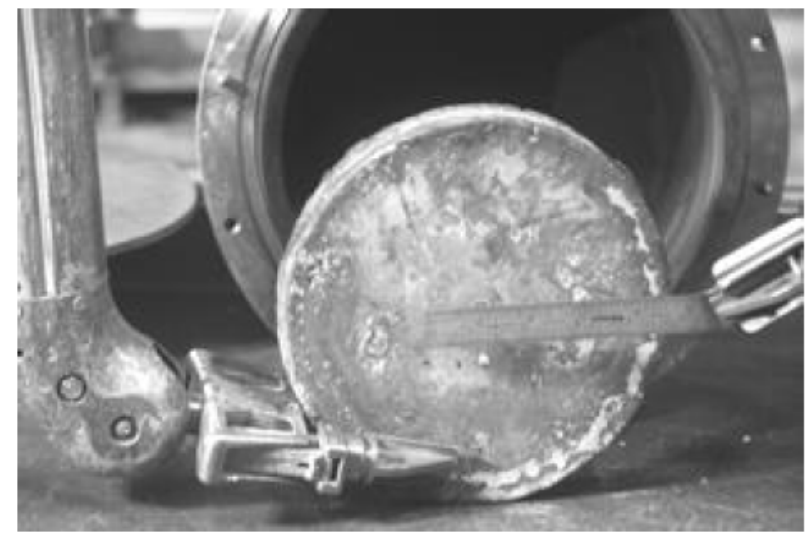

Figure 6.2. Photograph of Metal Waste Form Sample, from (Ebert 2005)
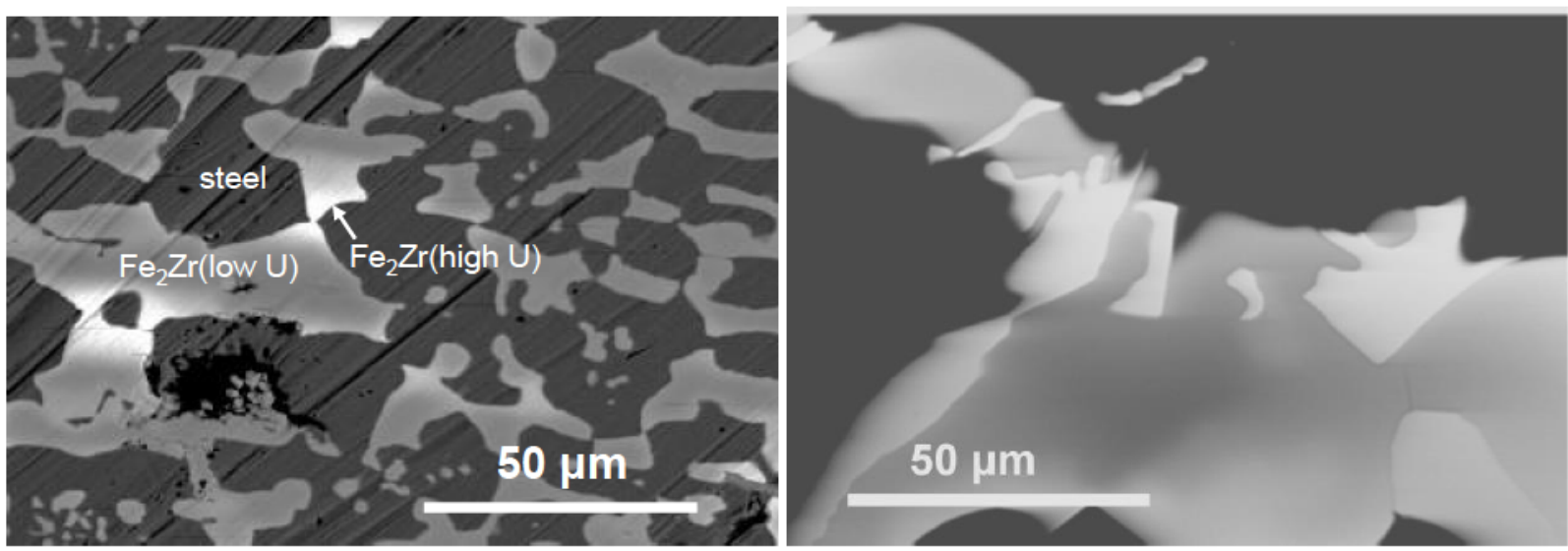

Figure 6.3. Microstructures of (a) 316SS-15Zr-10U Alloy Showing Steel and $\mathrm{ZrFe}_{2}$ Intermetallic Phases with Brighter Areas Having High U Concentration and (b) HT-9SS-2Zr-5U with the Same Fe-Zr-U Intermetallic Phases (Olson 2012). 
Early analyses of the chemical durability of the $316 \mathrm{SS}-15 \mathrm{Zr}$ waste form included immersion tests to directly measure the releases of $\mathrm{Tc}$ and $\mathrm{U}$ as the waste form corroded and routine electrochemical measurements to evaluate polarization resistance and galvanic couples of clean surface (Ebert 2005). This approach showed the metal waste form performance could be bounded by the HLW glass model in the Yucca Mountain safety analysis (Ebert 2005). This was a purely empirical approach with no mechanistic basis.

Recent studies have established scientific basis for developing an improved degradation model to provide radionuclide source terms for use in performance assessments (Cunnane 2009, 2010; Ebert 2014). That model is based on electrode kinetic theory to describe the oxidation reactions that free radionuclides and host elements from the alloy and the passivation of the alloy surface that significantly attenuates corrosion. The stability of the passivation layer that forms on steel-based waste forms and its capacity for regeneration are important factors affecting the long-term corrosion behavior. An experimental method has been developed (see discussion in Section 4.5.3) wherein electrochemical measurements are combined with solution analyses made during the experiments to correlate the releases of Tc and U into solution with the electrochemical response and with microscopy of the corroded specimen to identify the actively corroding phases (Ebert and Kolman 2013; Ebert 2014).

Experiments conducted in various electrolyte solutions that span the range of seepage waters in possible disposal systems and redox conditions provide model parameter values for calculating long-term radionuclide release rates. Corrosion is usually dominated by one phase that dissolves anodically and the others act as cathodes, depending on the corrosion potential imposed by the solution. For example, Figure 6.4a shows the surface of a 75SS-15Zr-10U alloy corroded in an acidic solution at a fixed potential of $70 \mathrm{mV}$ in which some domains of the U-rich Fe-Zr phase have completely dissolved while the neighboring steel phases and other areas of the electrode were unreacted. Small particles of U-bearing corrosion products are present on the surface. Residual stresses in the alloy and defects generated during surface preparation can cause localized corrosion to occur on even small electrodes. Figure $6.4 \mathrm{~b}$ shows the surface of a similar alloy made with less 316 stainless steel, $\mathrm{Zr}$, and U, and with noble metal fuel wastes $\mathrm{Mo}, \mathrm{Ru}, \mathrm{Rh}$, and $\mathrm{Pd}$ that was reacted under the same conditions without visible corrosion. The presence of these noble metals in the waste streams appears to benefit the waste form.

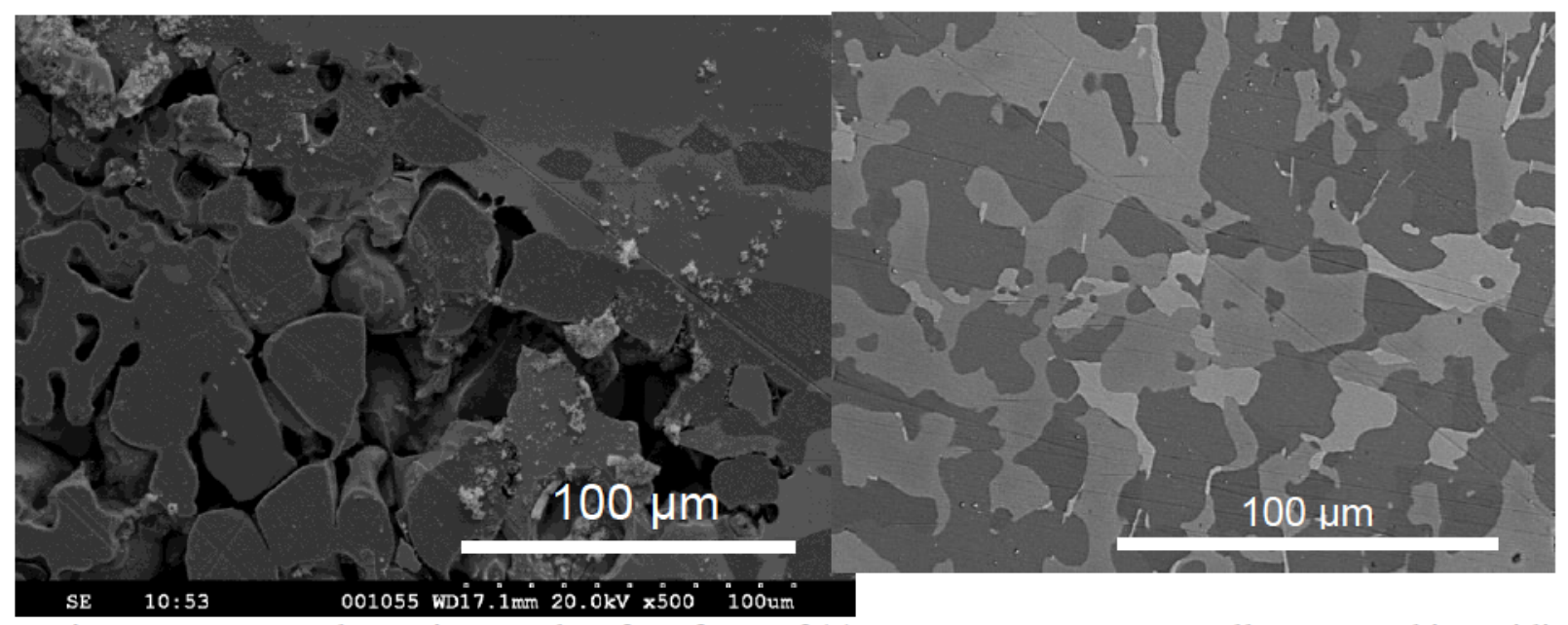

Figure 6.4. SEM Photomicrographs of Surfaces of (a) 75SS-15Zr-0NM-10U Alloy Reacted in Acidic Solution Showing Preferential Dissolution of Fe-Zr-U Intermetallic and (b) 60SS-12Zr-26NM-2U Alloy Reacted under the Same Conditions with No Visible Corrosion. 
The presence of multiple phases and the composition of those phases affect the corrosion behavior of alloyed waste forms and the release of radionuclides from those phases, and localized corrosion further complicates the modeling of the degradation behavior. An alloy waste form degradation model is being developed to provide radionuclide source term values for use in performance assessment calculations for potential engineered waste disposal systems (Ebert 2014). Radionuclide release occurs as the waste form corrodes by an oxidative-dissolution process in which the radionuclide and surrounding host metal are first oxidized and then the oxides dissolve. The oxidation occurs through electrochemical reactions with the solution contacting the alloy surface; the oxidation rate depends on the amounts of redox-sensitive species in the solution and the relative stabilities of the constituent alloy phases. The solution composition affects the radionuclide release rates electrochemically through the effects of redox-active components on the oxidation rate and chemically through the effects of $\mathrm{pH}$ and complexation on radionuclide solubility. Dissolved chloride is key chemical component of the solution that destabilizes passive layers formed on Cr-bearing phases.

Electrode kinetic theory provides the scientific basis for developing the degradation model, but is too complicated to implement directly to model multi-phase alloy waste forms. Instead, a semi-empirical modeling approach is being followed in which experimentally-measured values are used to determine analytical dependencies of the corrosion and dissolution rates on environmental variables and represent the effects of passivation and oxide dissolution on the release of radionuclides. Electrochemical test methods have been designed specifically to provide data needed to determine environmental dependencies and measure parameter values. Tests are being conducted with several representative alloys in various solution compositions representing a wide range of disposal environmental conditions, including acidic, neutral, and alkaline solutions with and without $\mathrm{NaCl}$, a range of $\mathrm{NaCl}$ brine solutions, various dissolved oxygen and hydrogen concentrations, and various temperatures (Ebert and Kolman 2013). Tests are conducted using electrodes fashioned from several representative alloys for extended periods of several weeks to measure the effects of forming passive corrosion layers on the oxidation rate. The release of radionuclides (primarily Tc and $\mathrm{U}$ ) into solution is measured periodically during the tests to correlate the radionuclide release rates with the active and passive oxidation rates and maturation of passivating layer. After the experiments, the corroded electrodes are examined with SEM to identify which phase was active during the experiment.

The alloy degradation model includes terms representing the electrochemical behavior of the bare surface, the stabilizing effect of a passivation layer, and the resistance to dissolution on the radionuclide release rate. All terms are sensitive to the corrosion environment and relate the rate of interest (the radionuclide source term) to the release mechanism. The bare surface behavior depends on the redox potential established by the groundwater and galvanic interactions between constituent phases of the waste form, the passivation term depends on the $\mathrm{Cr}$ content of the waste form and the $\mathrm{Cl}$ content of the groundwater, and dissolution term depends on the oxidation state of the radionuclide. Passivation can attenuate the bare surface oxidation rate by two or three orders of magnitude and can be promoted by adding trim $\mathrm{Cr}$ to the waste form. Electrode kinetics theory provides confidence that the behavior measured in experiments represents long-term corrosion behavior.

\subsection{Data Gaps and Research Needs}

Significant development has been made on 300 -series stainless steel based waste forms, but work has just started with the newer HT-9 based formulations. The required testing includes formulation of the base metal alloy, composition envelop definition, performance model development, durability parameter testing, waste form compliance strategy development, process testing, and technology maturation. The results of initial scoping tests indicate the testing and modeling approaches developed using tests with 316-based alloys will be directly applicable to alloys made with HT-9 stainless steel. 


\section{TRITIUM REMOVAL AND ENRICHMENT TECHNOLOGIES}

Future nuclear fuel reprocessing facilities will be required to reduce tritium released to the environment. There are several alternatives for reducing the release of ${ }^{3} \mathrm{H}$ from the wastewater of a reprocessing plant. These alternatives include recycling of wastewater combined with treatment to reduce volume of tritiated waste with subsequent long term containment (waste disposal) or storage. Recycling of wastewater alone has a limited effect due to increased risk to the workers and limited need for relatively clean contaminated water or nitric acid. Direct disposal of solidified tritiated waste water is feasible, but it creates large volumes if the ${ }^{3} \mathrm{H}$ is mixed with dissolver solutions, process condensates, and other waste streams and therefore most of the reprocessing streams. Volume reduction alternatives include technologies for heavy water reactor water clean-up, reactor coolant clean-up, and fusion reactor ${ }^{3} \mathrm{H}$ removal systems, but these removal processes are expensive to install and operate. Containment or disposal alternatives include injection of tritiated waste-water into suitable deep geological formations or large water sources, solidification and burial, intermediate length monitored storage (hundreds years) of concentrated tritium to allow for use of tritium or decay products such as ${ }^{3} \mathrm{He}$ to replace the dwindling supply from the Darlington and Wolsung tritium reclamation facilities (Kouzes et al. 2010, 2011; Ni et al. 2013; Pickrell et al. 2013).

The baseline capture method from reprocessing plants is by conversion of elemental tritium $\left({ }^{3} \mathrm{H}_{2}\right.$ and $\left.{ }^{3} \mathrm{HH}\right)$ to water $\left({ }^{3} \mathrm{H}_{2} \mathrm{O}\right.$ and $\left.\mathrm{H}^{3} \mathrm{HO}\right)$ and collection of all tritiated water by condensation and absorption on a molecular sieve. The molecular sieve collected water can solidified with cement, bitumen or other materials. Water may also be treated to remove other radioactive contaminants, such as ${ }^{14} \mathrm{C}$, that may affect waste designation and disposal alternatives.

Other facilities purify the ${ }^{3} \mathrm{H}$ to significantly reduce storage volume, at the expense of additional processing, for long-term storage as a solid tritide and for future use of the tritium or the ${ }^{3} \mathrm{He}$ decay product. The significant volume reduction increases the safety of the subsequent steps such as transport, interim storage and final disposal of tritiated waste. Furthermore, additional treatment decreases the corresponding overall waste management cost, although the cost for enrichment is very high. Results from groundwater treatment studies at the Hanford Site or LWR coolant treatment studies have not been implemented because of cost. Based on the stage of large-scale development, combined electrolysis with catalytic exchange systems should be the baseline process combined with large scale distillation columns as an alternative first step. However, a cost-to-benefit analysis is needed to justify the processing cost compared with direct disposal.

The analysis presented here assumes a reprocessing plant with a capacity of $1000 \mathrm{tU} / \mathrm{y}$. The waste-water stream with the largest ${ }^{3} \mathrm{H}$ content includes the dissolver solution, collected condensate from the dissolution process, and waste treatment process. The acid solutions are assumed to be recycled with a periodic purge to minimize tritium buildup. The purge stream and the condensate from the acid recycle process contain significant quantities of tritium. The waste water source is primarily collected from aqueous dissolution and the solvent extraction process.

The estimated sources of the ${ }^{3} \mathrm{H}$ are provided in Table 7.1 for PWR fuel with a burn-up of $50 \mathrm{GWd} / \mathrm{tU}$ as an example. The tritium inventories that need to be treated depend on the dissolution processes and how the zircaloy cladding and associated tritides, which form in the zircaloy during reactor operations and on the fuel manufacturing processes (Jubin et al. 2012b). For the purposes of mass balances used in this report it's assumed that $25 \%$ of the ${ }^{3} \mathrm{H}$ resides in the cladding and $75 \%$ in the fuel. 
Table 7.1. Tritium Source Terms for $50 \mathrm{GWd} / \mathrm{tU}$ PWR Fuel.

\begin{tabular}{|l|c|c|c|c|}
\hline \multicolumn{1}{|c|}{ Component } & \multicolumn{2}{c|}{ Activity, $\mathbf{C i} / \mathbf{t} \mathbf{U}$} & \multicolumn{2}{c|}{ Mass, g/tU } \\
\hline Cooling & $\mathbf{5 y}$ & $\mathbf{5 0} \mathbf{y}$ & $\mathbf{5 y}$ & $\mathbf{5 0} \mathbf{y}$ \\
\hline${ }^{3} \mathrm{H}$ (fission) & 468 & 37 & 0.048 & 0.0039 \\
\hline${ }^{3} \mathrm{H}$ (activation) & 158 & 13 & 0.016 & 0.0013 \\
\hline Total $^{3} \mathrm{H}$ & 626 & 50 & 0.065 & 0.0052 \\
\hline
\end{tabular}

Three options for managing ${ }^{3} \mathrm{H}$ are considered:

1) Tritium can be removed before dissolution by the tritium pretreatment process resulting in a low volume $(2-25 \mathrm{~g} / \mathrm{tU}$ or 0.002 to $0.025 \mathrm{~L} / \mathrm{tU})$ of highly concentrated tritiated water. See Section 2.1 for a detailed discussion.

2) Manage the high-volume water streams discharged from the plant. If all of the water were to be released from the facility, the releases from a baseline plant would be expected to be approximately $5000 \mathrm{~kg} / \mathrm{tU}$ and exceed ${ }^{3} \mathrm{H}$ release limits without some controls (Willis et al. 2013). The concentration of ${ }^{3} \mathrm{H}$ in the reprocessing facility waste water stream without enrichment is estimated to be between 10 and $100 \mathrm{Ci} / \mathrm{m}^{3}$. The criteria for discharge to the environment are $1.0 \times 10^{-7} \mathrm{Ci} / \mathrm{m}^{3}$ for air discharge and $1 \times 10^{-3} \mathrm{Ci} / \mathrm{m}^{3}$ for water discharge at the site boundary (10CFR20), assuming total dose limits don't further restrict discharge. Most of the discharged water would have sufficient tritium concentrations to require immobilization and disposal. There is the possibility of limiting the volume of water with ${ }^{3} \mathrm{H}$ concentrations that exceed the discharge limit by plant design and operating strategy as described by Areva (2013). This approach may reduce the high-tritium water volume to less than $300 \mathrm{~kg} / \mathrm{tU}$.

3) The ${ }^{3} \mathrm{H}$ can be concentrated into a small volume stream by ${ }^{3} \mathrm{H}$ enrichment processes described in the following subsection.

\subsection{Method for Enrichment of Tritium in Waste Water}

Several methods have been used to enrich the ${ }^{3} \mathrm{H}$ in a small volume water stream. This subsection surveys some of the approaches.

\subsubsection{Combined Electrolysis and Catalytic Exchange}

Combined electrolysis catalytic exchange (CECE) is one of several processes based on the hydrogen exchange in water that favors formation of liquid tritiated water when liquid $\mathrm{H}_{2} \mathrm{O}$ is contacted with tritiated hydrogen $\left({ }^{3} \mathrm{HH}\right.$ or $\left.{ }^{3} \mathrm{H}_{2}\right)$ gas (Sienkiewicz and Lentz 1988):

$$
{ }^{3} \mathrm{HH}(\mathrm{g})\left[{ }^{3} \mathrm{H}_{2}\right]+\mathrm{H}_{2} \mathrm{O}(\mathrm{l}) \rightarrow \mathrm{H}^{3} \mathrm{HO}(\mathrm{l})+\mathrm{H}_{2}(\mathrm{~g})\left[{ }^{3} \mathrm{HH}\right]
$$




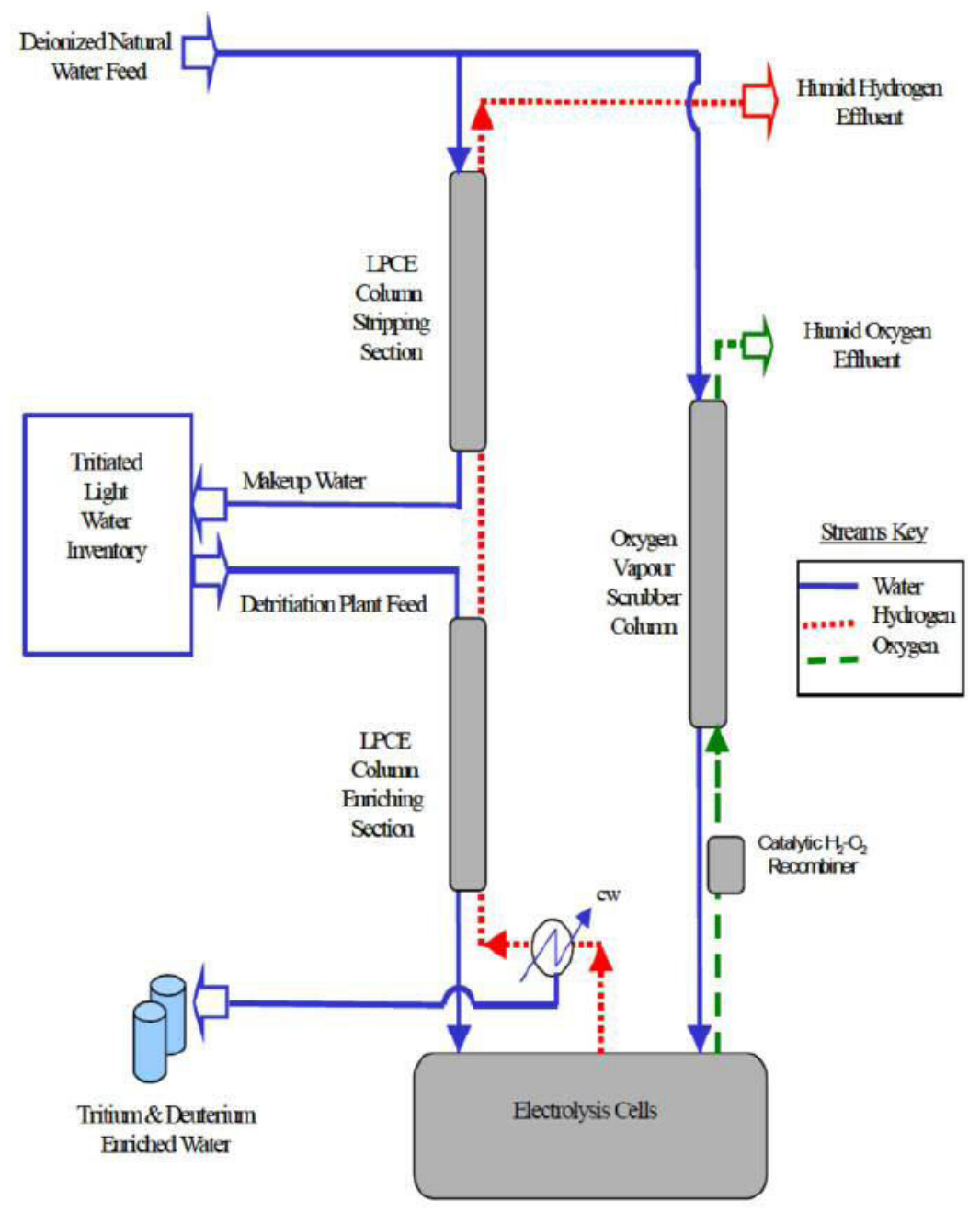

Figure 7.1. Example CECE Process Schematic (from Willis et al. 2013).

The CECE process, schematically shown in Figure 7.1, has a high isotopic separation factor at near ambient temperature and pressure operating conditions. A catalyst is required for the reaction to proceed at an appreciable rate and the development of improved hydrophobic catalysts in recent years has been key to the commercial success of the process.

The process requires electrolysis of all feed water plus some deionized water used for stripping (approximately 1.4 times the feed flow is electrolyzed). Therefore, the energy costs are significant for large throughput.

A CECE-type pilot plant to recover ${ }^{3} \mathrm{H}$ from light water was built and operated in Japan for over $14 \mathrm{y}$ in connection with the Fugen reactor. The plant capacity was $3.6 \mathrm{~L} / \mathrm{d}$ of feed, and tritiated water was concentrated by a factor of $10^{4}$ (Isomura et al. 1988).

Additionally, CECE systems are used for ${ }^{3} \mathrm{H}$ separation from heavy water in the Darlington facility in Canada (Sood et al. 1990) and the Wolsung facility in South Korea (Ahn 2006, Ni et al. 2013). The processing rates are lower than required for the reprocessing facility design basis, but are the same order of magnitude. The systems are well developed and there is a great deal of operating experience with them. Enhancements to the system are being continually developed and would be available for light water tritium separations. Some design work is being conducted in support of the International Thermonuclear Experimental Reactor (ITER) and Joint European Torus (JET) fusion reactor programs 
(Sood et al. 1995). The Canadian and Korean facilities do not require ultra-clean heavy water and allow higher concentrations in the water stream than would be required for discharge to the environment from a reprocessing facility. Purified tritium for long term storage is also collected and used rather than dispose of as waste. The total quantity of tritium produced at CANDU heavy water reactors is significantly higher than at light water reactors. Cryogenic distillation is used for final purification of the ${ }^{3} \mathrm{H}$. Considering the reduced total quantity, purification for reuse is considered financially unsound.

Electrolytic cells are an important part of the CECE process. Recent development and testing is focused on use of a solid polymer electrolyte and membranes. This reduces the cell size to about $1 / 3$ that of the more conventional alkaline cells. Active development and testing of improved electrolytic cells is ongoing at several sites (Ogata 2003, 2005; Cristescu et al. 2006; and Michling 2008).

A successful demonstration of the CECE process was as part of the Atomic Energy Canada, Limited (AECL) Prototype CIRCE Plant demonstration project at Hamilton, Ontario Canada (Klem 2004). A 7.5 $\mathrm{kA}$ electrolysis cell and a 2-inch diameter column with a total water flow of approximately $1.5 \mathrm{~L} / \mathrm{h}$ is used at the pilot plant. During testing, a detritiation factor exceeding 30000 was achieved (Miller 2001).

A cost estimate by AECL (Miller 1999) prepared for the SRS provides a rough costs that may be expected. With escalation to 2009 , the costs approached $\$ 0.50 / \mathrm{L}(\$ 2 / \mathrm{gal})$.

\subsubsection{Bithermal}

The Bithermal process for ${ }^{3} \mathrm{H}$ recovery consists of cold-stripping and cold-enriching columns and hotenriching and hot-stripping columns stacked in a vertical orientation with hydrogen gas flowing upward countercurrent to the aqueous streams. Tritiated water to be treated is introduced between the coldstripping and cold-enriching columns. Three conditions are important to maximizing separation factors: 1) use of an active hydrophobic catalyst, 2) temperature control to enhance the stripping and enriching conditions, and 3) high pressure. However, some catalysts developed for CECE are unsuitable because the upper temperature limit is about $100^{\circ} \mathrm{C}$, which is lower than the optimum temperature for the Bithermal process (Andreev et al. 2007). In the upper "cold stripper" section, non-tritiated water is used to absorb tritium from the circulating hydrogen. The resulting hydrogen gas, essentially free of tritium is recirculated to the hot-stripping column to remove ${ }^{3} \mathrm{H}$ from the wastewater before discharge. The ${ }^{3} \mathrm{H}$-rich product stream is withdrawn from between the cold and hot enrichment columns. The columns are operated at near $5 \mathrm{MPa}$ pressure to achieve maximum separation factors. The hot enrichment and stripping column sections are operated at about $443 \mathrm{~K}\left(170^{\circ} \mathrm{C}\right)$, and the cold-stripping and coldenrichment column sections are operated at about $323 \mathrm{~K}\left(50^{\circ} \mathrm{C}\right)$. A prototype unit was installed and operated successfully at the Prototype Combined Industrial Reforming and Catalytic Exchange (CIRCE) demonstration project at Hamilton, Ontario Canada (Klem 2004).

Concerns with the Bithermal process include: 1) the containment of tritiated water and tritiated hydrogen gas under high pressure, 2) safety with the use of high-pressure hydrogen gas in the process, and 3) the fact that the process has not been used on a large industrial scale. In addition, the process flows are more difficult to control than those in the CECE process.

\subsubsection{Water Distillation and Rectification}

Water distillation of tritiated water is the simplest separation method. It relies on the boiling point difference $\left(1.5^{\circ} \mathrm{C}\right)$ between tritiated water and ordinary water. The method is used at heavy water plants for the first crude separation of deuterium from protium. However, due to the low relative volatility $\left[\mathrm{p}\left(\mathrm{H}_{2} \mathrm{O}\right) / \mathrm{p}\left({ }^{3} \mathrm{HHO}\right)=1.056\right]$ and the high throughput $(7 \mathrm{~L} / \mathrm{s})$, water distillation requires $>200$ theoretical plates), a high reflux ratio ( $>25)$, and multiple large-diameter distillation columns $(>7.3 \mathrm{~m})$. The high reflux rate means the process consumes approximately thirty times more energy than single-pass 
evaporation. Some economy may be gained by mechanical vapor recompression of the overheated steam from the column to heat the reboiler, but adds to the contaminated equipment inventory requiring maintenance. Rough sizing for a plant to handle $\sim 0.7 \mathrm{~kg} / \mathrm{s}$ could include a primary column 30 meters (100 feet) high and $7 \mathrm{~m}$ in diameter with secondary columns $24 \mathrm{~m}$ high and $2.4 \mathrm{~m}$ in diameter. Water distillation is used as heavy water upgraders for the CANDU reactors to remove tritium and increase deuterium concentrations (Sood et al. 1990).

Water distillation was proposed for tritium removal from reactor coolant in US at similar rates to systems used for heavy water production. An integrated system in which water distillation, palladium metal membrane separation, and thermal diffusion is used has been developed at GE-Hitachi Nuclear Energy (GE) and installed at a commercial site in the UK where small volumes of radiochemicals are produced (Geniesse and Stegen 2009).

\subsubsection{Girdler Sulfide}

Like the Bithermal hydrogen water process, the Girdler Sulfide (GS) process uses cold and hot columns and a recirculating gas to drive the separation process (Miller and Van Alstyne 1994). However, in the GS process hydrogen sulfide is the recirculating gas and no catalyst is required. The GS process is described in more detail in Jeppson et al. (1997).

In the Miller (1999) evaluation, the GS process was judged to cost somewhat more than the CECE process or a bithermal hydrogen-water process for the specific scenarios evaluated.

\subsubsection{Cryogenic Distillation}

This process is only used for small quantities of highly purified tritium already and is operated as a distillation column at very low temperatures. The process requires elemental hydrogen and no water in the system.

\subsubsection{Thermal Cycle Absorption Process}

The thermal cycle adsorption process (TCAP) separative capacity is comparable to a batch cryogenic distillation system. The system has been used for many years at Savannah River for relatively high concentration of tritium in a hydrogen stream. The system is a semi-continuous chromatographic process for isotope separation that utilizes palladiums large isotopic effect (an effect that decreases with temperature). The chromatographic separation utilized thermal absorption and desorption cycle to separate the hydrogen isotopes. The system consists of a packed active column and a larger column of diatomaceous earth called a plug flow reverser. Palladium coated on a high surface area diatomaceous earth is used as the active packing material. Savannah River uses a $\mathrm{LaNi}_{4.25} \mathrm{Al}_{0.75}$ for hydrogen storage during the processing to help maintain the compact size. The system operates under moderate conditions with a high hydrogen density to maintain a small compact system. The operation of the system could be modified to detritiate very low ${ }^{3} \mathrm{H}$ concentration streams of hydrogen. The overall system size, cost, and operating conditions would need be determined and tested. The system could be combined with other technologies for ${ }^{3} \mathrm{H}$ separation and for converting tritiated water to hydrogen gas (Horen and Lee 1991).

\subsubsection{Integrated Systems}

At GE-Hitachi Nuclear Energy (GE), several integrated system concepts for processing tritium contaminated wastes have been developed. These systems are designed to reduce environmental emissions and, in some cases, recover ${ }^{3} \mathrm{H}$ for beneficial use. The initial integrated process was installed at 
the GE manufacturing site located near Cardiff, UK and resulted in a large reduction in ${ }^{3} \mathrm{H}$ discharges to the environment (Bonnett et al. 2008).

\subsubsection{Summary and Recommendations}

There are several process and option for tritium handling depending on site characteristics and energy costs. A summary of the technologies deployed at significant scale is shown in Table 7.2 (Sood et al. 1995). As essentially isotopic enrichment technologies, each of these systems can be scaled to concentrate the ${ }^{3} \mathrm{H}$ as high as desired for waste management. The ultimate extent of concentration will depend on relative costs of construction and operation of the enrichment facility and the waste form fabrication, storage, and disposal.

Table 7.2. Tritium Removal Technologies in Commercial Use - Operating and Proposed Facilities

\begin{tabular}{|c|c|c|c|}
\hline Facility & Technologies & $\begin{array}{c}\text { Input Capacity, } \\
\mathbf{k g} / \mathbf{h r}\end{array}$ & $\begin{array}{c}\text { Input }{ }^{3} \mathbf{H}, \\
\mathbf{C i} / \mathbf{k g}\end{array}$ \\
\hline $\mathrm{D}_{2} \mathrm{O}$ Upgraders & Distillation & $40-300$ & $1-30$ \\
\hline Bruce $\mathrm{D}_{2} \mathrm{O}$ Plant & Distillation & 1000 & $\begin{array}{c}\text { No }{ }^{3} \mathrm{H} \text { gas, } \\
{ }^{2} \mathrm{HHO}\end{array}$ \\
\hline Darlington, TRF & VPCE & 360 & 30 \\
\hline Grenoble & VPCE & 21 & 3 \\
\hline AECL Test & LPCE & 6 & 23 \\
\hline Chalk River, TEP & LPCE & 20 & 35 \\
\hline Mound & CECE & 0.24 & "high" \\
\hline Mol & CECE & 1.6 & $2 \times 10^{-6}$ \\
\hline KFK & CECE & 1 & 0.1 \\
\hline FUGEN & CECE & 1 & 4 \\
\hline Wolsung & LPCE & 100 & Not reported \\
\hline
\end{tabular}

The least expensive disposal is for mixing with surrounding water source, if available, to meet the site boundary release limits. If that is not possible, the CECE process has the most experience. The CECE process has high electrical costs and requires handling significant quantities of hydrogen gas. Based on the stage of large-scale development, CECE systems should be the baseline process combined with large scale distillation columns as an alternative first step. However, a cost-to-benefit analysis is needed to justify the processing cost compared with direct disposal.

For the purposes of this report it is assumed that the ultimate enrichment achieved is that described by Willis et al. (2013). That study assumed an $800 \mathrm{tU} / \mathrm{y}$ plant operating for $300 \mathrm{~d} / \mathrm{y}$ and treating 15 to 17 $\mathrm{m}^{3} / \mathrm{d}$ of tritiated water. The CECE process would produce 20 to $50 \mathrm{~L} / \mathrm{d}$ concentrated product ( 85 to 220 $\mathrm{Ci} / \mathrm{kg}^{3} \mathrm{H}$ ). These represent a 340 to $750 \times$ concentration of high ${ }^{3} \mathrm{H}$ water. It is assumed that the process will be operated to minimize the high-tritiated water requiring treatment to the values estimated by AREVA (2013) $(300 \mathrm{~kg} / \mathrm{tU})$ followed by CECE concentration by $500 \times$ resulting in $0.6 \mathrm{~kg} / \mathrm{tU}$ tritiated water for immobilization.

\subsection{Tritiated Water Immobilization}

Tritium management approaches considered in this report include:

1) Capture of tritiated water from the gas stream of a TPT process on MS3A followed by release at elevated temperature and condensation as a tritiated water stream. This option would generate roughly $10 \mathrm{~g} / \mathrm{tU}$ of tritiated water form immobilization. 
2) Immobilization of high volume aqueous stream from reprocessing which would generate between 300 and $5000 \mathrm{~kg} / \mathrm{tU}$ of tritiated water for immobilization.

3) Concentrating tritiated water from the high volume aqueous stream to a low volume tritiated water stream which would generate roughly 0.6 to $10 \mathrm{~kg} / \mathrm{tU}$ of tritiated water for immobilization.

The relatively short half-life of ${ }^{3} \mathrm{H}$ (12.26 y) shows that the performance of the waste form for tritiated water in near surface (i.e., low-level waste, LLW) disposal need only be on the order of $100 \mathrm{y}$. Normal cement waste forms are appropriate for the immobilization of LLW for on the order of 1000's of years. The GNEP studies recommended the tritiated water from the TPT process be immobilization in cement (Gombert et al. 2007). Although the cement waste forms are known to last for 1000's of years, the high mobility of water in cement is likely too high for adequate protection (Eichholz 1988, NEA 1980, and Tits et al. 2003) and additional barriers to ${ }^{3} \mathrm{H}$ release will be required. Plastic or steel high integrity containers (HIC) are likely to be required for disposal for cement waste forms. These containers are regularly used and are certified for more than the $100 \mathrm{y}$ required life. Later waste form volume studies therefore assumed the cemented tritiated water was to be disposed of in 10-L poly-bottle HIC's (Carter et al. 2011). If HIC's are used then cementation becomes optional, absorbents such as vermiculite or clay may be sufficient to immobilize tritiated water contained in HICs. The NEA study on tritiated water management concluded that the incorporation of tritiated water in cement with secondary containment is preferred unless the tritium is highly enriched, in which case zirconium hydride is favored (NEA 1980).

There is also the potential to make commercial use of the separated ${ }^{3} \mathrm{H}$. Tritium is currently used as a component in "self-powered" lights, as a tracer/label for medical research, and as a material in fusion research. Tritium is also used in nuclear weapons. The global nonmilitary tritium market is estimated at about 400 g per year. Ontario Power operates a tritium removal facility that produces about $2.5 \mathrm{~kg}$ of tritium per year which overwhelms the current market. Unless there is an increase in demand for tritium, it is unlikely to enter into the commercial market. Another potential indirect market exists for ${ }^{3} \mathrm{He}$, the decay product of ${ }^{3} \mathrm{H}$. This isotope of $\mathrm{He}$ is used in neutron detectors and the supply of this critical isotope is low (Kouzes et al. 2010; Kouzes et al. 2011; Ni et al. 2013; Pickrell et al. 2013). Currently there are limited sources for this isotope. It is possible that the HIC system could be designed for eventual recovery of ${ }^{3} \mathrm{He}$ following sufficient decay time.

For the purposes of this report, it is assumed that tritiated water is cemented and stored in HIC's. Grouting is a well-developed technology for stabilizing a variety of waste forms. No problems are anticipated for this method of disposing of a purified tritiated water stream (assuming other cocontaminants do not change the waste classification, such as ${ }^{129} \mathrm{I}$ ).

Because tritiated water is one of the streams being immobilized, care must be taken to avoid evaporative losses to high-volume off-gas streams. A low-water cement is therefore fabricated in a sealed drum system. The total water to solids ratio (mass water per mass combined ordinary portland cement [OPC], fly ash [FA], and blast furnace slag [BFS]) of roughly 0.25 is required to fully complete the hydration reactions in most cements. However, it is difficult to mix and move cements with such low ratios. A ratio of typical cements range from 0.4 to 0.7 which give a good mix of properties. Low water cements are formed to increase the strength and also reduce evaporation during processing. Low water cements have ratios between 0.25 and 0.4 and often include additives to improve mixing and flow such as plasticizers. A tritiated water to solids ratio of 0.3 will be assumed for the final cement.

A sealed in-drum cementation process, such as MOSS (Figure 7.2), is appropriate for use (Gesser et al. 2000). By this process, dry blends of OPC, BFS, and FA are blended and pre-staged in the drum with a disposable mixer blade. The liquids and slurried solid encapsulates are added to the dry solid blend in the drum and mixed by agitating the disposable mixer through a seal. The cement is allowed to set and sampled as necessary. Assuming a loading of tritiated water of roughly $30 \mathrm{mass} \%$ in the final cement, waste form that fills $90 \%$ of the drum volume, and a density of roughly $1.9 \times 10^{3} \mathrm{~kg} / \mathrm{m}^{3}$, the anticipated masses and volume of cemented tritiated water are summarized in Table 7.3. 
It is likely that the tritiated water (with or without sorbent) will be combined with other LLWs into a combined waste stream cement. This is discussed in Section 9.

Table 7.3. Tritium Cement Masses and Volume Summaries

\begin{tabular}{|l|l|l|l|}
\hline Tritiated Water Stream & Water mass, $\mathbf{k g} / \mathbf{t U}$ & Cement mass, $\mathbf{k g} / \mathbf{t U}$ & $\begin{array}{l}\text { Cement volume, } \\
\mathbf{m}^{\mathbf{3}} / \mathbf{t U}\end{array}$ \\
\hline Tritium pretreatment off-gas & 0.002 to 0.025 & 0.0063 to 0.079 & $\begin{array}{l}3.3 \times 10^{-6} \text { to } 4.1 \times \\
10^{-5}\end{array}$ \\
\hline High volume aqueous discharge & 5000 & 15000 & 0.8 \\
\hline Optimized high-volume aqueous discharge & 300 & 500 & 0.16 \\
\hline $\begin{array}{l}\text { Isotopic enriched high-volume water } \\
\text { discharge }\end{array}$ & 0.6 to 10 & 2 to 33 & 0.001 to 0.018 \\
\hline
\end{tabular}




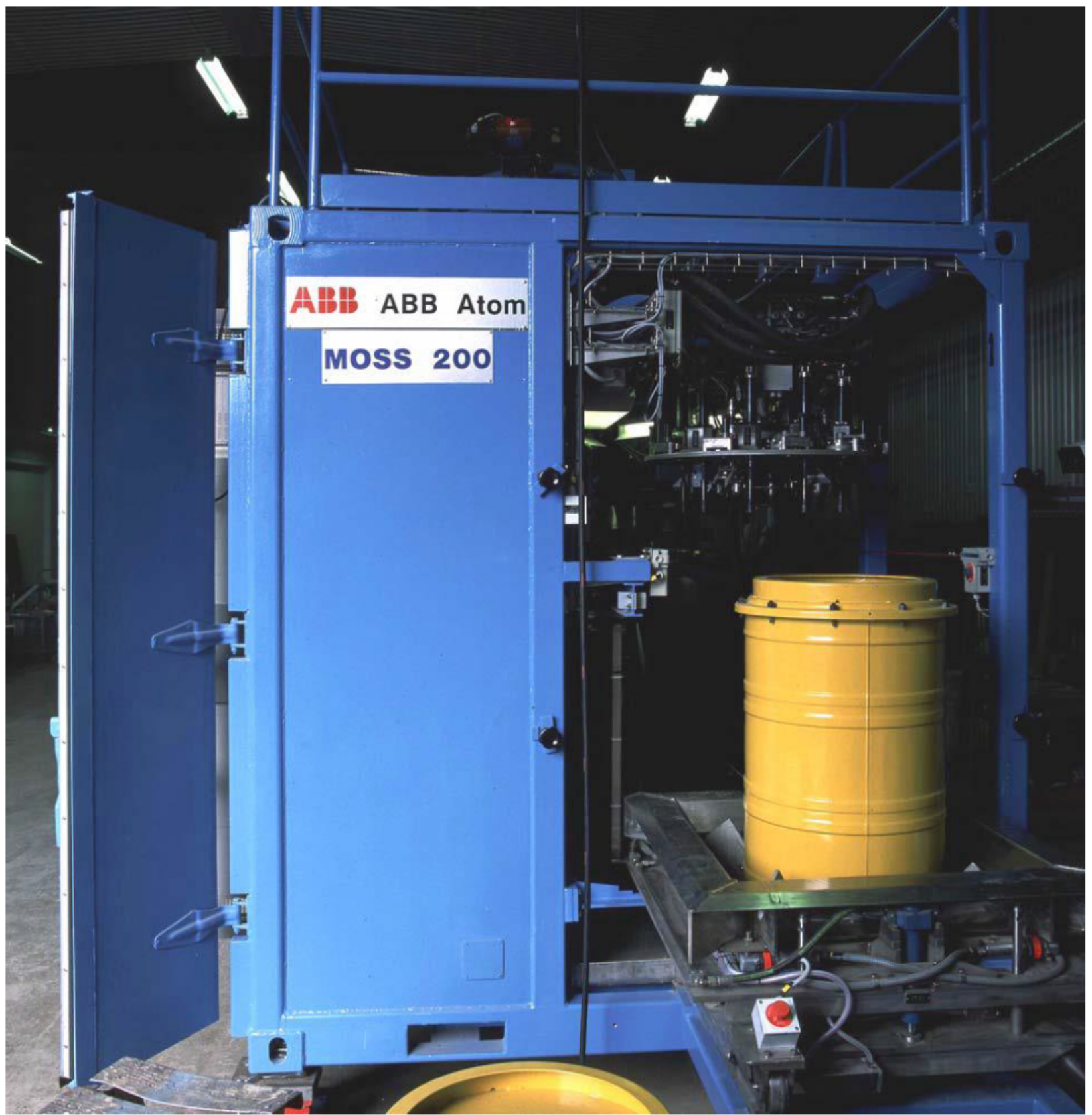

Figure 7.2. Photo of the MOSS unit with "lost-stirrer" to be utilized at Rossendorf (Gesser et al. 2000)

\subsection{Data Gaps and Research Needs}

- Demonstration of CECE and distillation on streams with low ${ }^{3} \mathrm{H}$ concentrations. The current technologies have been developed for higher ${ }^{3} \mathrm{H}$ concentration feed streams.

- Development of efficient process for large volume low concentration ${ }^{3} \mathrm{H}$ streams to reduce treatment costs. 
- Process demonstration for direct disposal of inexpensive media used for water capture at high efficiencies and high loadings.

- Collect sufficient design data and perform a cost benefit analysis to determine the most cost effective solution to ${ }^{3} \mathrm{H}$ management in an appropriately scaled plant. 


\section{SECONDARY WASTES}

For the purposes of this report, secondary wastes are generated during the handling of radioactive materials. These include wastes generated during operations and maintenance activities and wastes generated during routine operations to control the spread of contamination (i.e. job control wastes).

\subsection{Types of Secondary Wastes}

Operations wastes can include:

- Used multi-purpose canisters (MPCs)

- Fuel cask and canister decontamination wipes and filters

- Filtered solids

- Pool sludge

- Dewatered resins

- Solvent residues

- Containers from waste solidification processes

- Miscellaneous chemical wastes

- Solidified waste waters

- Spent ion exchange resins

- Packaging wastes

Maintenance wastes include:

- Failed instruments and electronic equipment

- Manipulator boots, arms, and counterweights

- Failed piping and valves

- Failed process vessels

- Failed pumps and agitators

- Various failed process-specific equipment

Job control wastes include:

- Gloves

- Shoe covers

- Protective clothing

- Step-off pads

- Containment hut material

Secondary wastes are classified according to their activity level as described in 10 CFR 61. Class A wastes have the lowest activity level, followed by Class B, Class C, and Greater Than Class C (GTCC). If the wastes also contain hazardous organic and/or inorganic chemicals, then they are called "mixed" Class A, Class B, Class C, or GTCC wastes.

\subsection{Secondary Waste Volumes}

Jones and Carter (2013) documented a comparison of estimated quantities of process and secondary wastes from a future UNF recycling facility and from MOX and fast reactor fuel fabrication facilities. This section summarizes the waste volume estimates from the Jones and Carter (2013) study. The reader 
is referred to that document and the references therein for detailed discussions of the assumptions and factors considered in their analysis.

Estimates of secondary waste volumes were compiled from four sources. DOE had contracted with two industrial partners, AREVA and Energy Solutions, to provide information based on their operating experiences. AREVA and Energy Solutions provided secondary waste volume estimates for recycling, MOX fabrication, and fast reactor fuel fabrication cases. Two estimates were available from the Used Fuel Disposition (UFD) Campaign within DOE-NE. The first UFD estimate is based on work done at the Savannah River Site (SRS) for the GNEP program to conduct Engineering Alternative Studies (EAS) and Follow-On Engineering Alternative Studies (FOEAS) for fuel recycling processes (Jones 2011a). This is designated as UFD/EAS in the waste volume tables that follow. The second UFD estimate is based on a later study in which the as-generated waste volumes were the same but the final waste volumes were reclassified according to radionuclide content of the waste streams (Jones 2012). This later estimate is designated as UFD-2012 in the tables that follow. Secondary waste estimates for MOX fuel fabrication were documented in a separate UFD study by Jones (2011b). There are no UFD-2012 waste volume estimates for MOX or fast reactor fuel fabrication, and there are no UFD waste volume estimates for fast reactor fuel fabrication.

Table 8.1 provides a summary of the ranges of secondary waste volumes for the cases of UNF recycling, MOX fuel fabrication, and fast reactor fuel fabrication. The recycling waste volumes are based on a 50 $\mathrm{GWd} / \mathrm{tU}, 5$-year cooled LWR used fuel. The volumes are normalized to $1 \mathrm{tU}$ from an $800 \mathrm{tU} / \mathrm{y}$ facility. The waste volumes shown for the MOX and fast reactor fuel fabrication are estimated from processing $800 \mathrm{t}$ of UNF per year (Jones and Carter 2013).

Table 8.2 and Table 8.3 provide the estimated secondary waste volumes for an $800 \mathrm{t} / \mathrm{y}$ UNF recycling facility. Three cases are presented:

- UNF-1: LWR uranium oxide fuel, $50 \mathrm{GWd} / \mathrm{tU}$ burnup, 5-year cooled

- UNF-2: LWR uranium oxide fuel, $50 \mathrm{GWd} / \mathrm{tU}$ burnup, 50-year cooled

- UNF-4: a blend of $90 \mathrm{tHM} / \mathrm{y}$ MOX (UNF-3) and $710 \mathrm{tU} / \mathrm{y}$ of UNF-1

where UNF-3 is a LWR MOX fuel, $50 \mathrm{GWd} / \mathrm{t}$ of initial heavy metal burnup, 5-year cooled.

Table 8.2 shows the estimated secondary waste volumes for a UNF recycling facility for the three fuel cases from the four studies. Table 8.3 shows the estimated secondary waste volumes based on the functional processing steps within the recycling facility.

Table 8.4 shows the estimated secondary waste volumes for a MOX fuel fabrication facility and Table 8.5 shows the estimated secondary waste volumes for a fast reactor fuel fabrication facility. 
Table 8.1. Summary of Secondary Waste Volumes for Fuel Recycling, MOX Fuel Fabrication and Fast Reactor Fuel Fabrication (from Jones and Carter 2013)

\begin{tabular}{|c|c|c|c|}
\hline \multirow[t]{2}{*}{$\begin{array}{l}\text { Functional } \\
\text { Area }\end{array}$} & \multirow[t]{2}{*}{$\begin{array}{l}\text { Waste } \\
\text { Classification }\end{array}$} & \multicolumn{2}{|c|}{$\begin{array}{c}\text { Waste Volume } \\
\left(\mathrm{m}^{3} / \mathbf{M T}\right)\end{array}$} \\
\hline & & Low & High \\
\hline \multicolumn{4}{|l|}{ Recycling $^{\mathbf{a}}$} \\
\hline & Class A & 2.96 & 3.86 \\
\hline & Class B & 0 & 1.73 \\
\hline & Class C & 0.12 & 1.45 \\
\hline & Total Class A/B/C & 3.59 & 7.59 \\
\hline & GTCC & 0.02 & 1.04 \\
\hline & Mixed Class A/B/C & 0 & 0.08 \\
\hline & Mixed GTCC & 0 & 0.06 \\
\hline \multicolumn{4}{|c|}{ MOX Fuel Fabrication $^{b}$} \\
\hline & Class A & 0.12 & 0.16 \\
\hline & Class B & - & - \\
\hline & Class C & - & - \\
\hline & Total Class A/B/C & 0.12 & 0.64 \\
\hline & GTCC & 0.03 & 2.79 \\
\hline & Mixed Class A/B/C & - & - \\
\hline & Mixed GTCC & - & - \\
\hline \multicolumn{4}{|c|}{ Fast Reactor Fuel Fabrication $^{b}$} \\
\hline & Class A & 0.08 & 0.09 \\
\hline & Class B & - & - \\
\hline & Class C & - & - \\
\hline & Total Class A/B/C & 0.08 & 0.09 \\
\hline & GTCC & 0.006 & 0.17 \\
\hline & Mixed Class A/B/C & - & - \\
\hline & Mixed GTCC & - & 0.006 \\
\hline \multicolumn{4}{|c|}{$\begin{array}{l}{ }^{\mathrm{a}} \text { Based on a recycling facility capacity of } 800 \mathrm{MT} / \mathrm{year} \\
{ }^{\mathrm{b}} \text { Normalized to same recycling capacity of } 800 \mathrm{MT} / \mathrm{year} \text {. } \\
\text { Actual capacity is lower and is based on processing quantity } \\
\text { of Pu from } 800 \mathrm{MT} \text { of UNF. }\end{array}$} \\
\hline
\end{tabular}


Table 8.2. Estimated Secondary Waste Volumes $\left(\mathrm{m}^{3}\right)$ by Waste Classification for $800 \mathrm{tU} / \mathrm{y}$ Recycling Facility (from Jones and Carter 2013)

\begin{tabular}{|c|c|c|c|c|c|c|c|c|c|c|c|}
\hline \multirow{2}{*}{$\begin{array}{c}\text { Waste } \\
\text { Classification }\end{array}$} & \multicolumn{4}{|c|}{ UNF1 } & \multicolumn{4}{|c|}{ UNF2 } & \multicolumn{3}{|c|}{ UNF4 (Blended UNF) } \\
\hline & UFD/EAS & UFD 2012 & AREVA & $\begin{array}{c}\text { Energy } \\
\text { Solutions }\end{array}$ & UFD/EAS & $\begin{array}{l}\text { UFD } \\
2012\end{array}$ & AREVA & $\begin{array}{c}\text { Energy } \\
\text { Solutions }\end{array}$ & UFD/EAS & AREVA & $\begin{array}{c}\text { Energy } \\
\text { Solutions }\end{array}$ \\
\hline Class A & - & 3091 & 2779 & 2372 & - & 3673 & 3439 & 3244 & - & 2779 & 2372 \\
\hline Class B & - & 1386 & 0 & 0 & - & 1273 & 0 & 0 & - & 0 & 0 \\
\hline Class C & - & 1157 & 95 & 1713 & - & 741 & 95 & 1713 & - & 136 & 1696 \\
\hline Total Class A/B/C & 6068 & 5633 & 2875 & 4085 & 6668 & 5687 & 3535 & 4957 & 6068 & 2915 & 4068 \\
\hline GTCC & 259 & 832 & 69 & 18 & 259 & 1233 & 69 & 18 & 259 & 86 & 18 \\
\hline Mixed Class A/B/C & 28 & 61 & 0 & 0 & 28 & 61 & 0 & 0 & 28 & 0 & 0 \\
\hline Mixed GTCC & 45 & 0.1 & 0 & 0 & 45 & 0.1 & 0 & 0 & 45 & 0 & 0 \\
\hline Total & 6400 & 6527 & 2944 & 4103 & 7000 & 6981 & 3604 & 4975 & 6400 & 3002 & 4087 \\
\hline
\end{tabular}

Table 8.3. Estimated Secondary Waste Volumes $\left(\mathrm{m}^{3}\right)$ by Functional Area for $800 \mathrm{tU} / \mathrm{y}$ Recycling Facility (from Jones and Carter 2013)

\begin{tabular}{|c|c|c|c|c|c|c|c|c|c|c|c|}
\hline \multirow{2}{*}{$\begin{array}{c}\text { Functional } \\
\text { Area }\end{array}$} & \multicolumn{4}{|c|}{ UNF1 } & \multicolumn{4}{|c|}{ UNF2 } & \multicolumn{3}{|c|}{ UNF4 (Blended UNF) } \\
\hline & UFD/EAS & UFD 2012 & AREVA & $\begin{array}{c}\text { Energy } \\
\text { Solutions }\end{array}$ & UFD/EAS & $\begin{array}{l}\text { UFD } \\
2012\end{array}$ & AREVA & $\begin{array}{c}\text { Energy } \\
\text { Solutions }\end{array}$ & UFD/EAS & AREVA & $\begin{array}{c}\text { Energy } \\
\text { Solutions }\end{array}$ \\
\hline $\begin{array}{l}\text { Receipt \& } \\
\text { Storage } \\
\end{array}$ & 277 & 232 & 108 & - & 877 & 831 & 768 & 872 & 277 & 108 & - \\
\hline Head End & 164 & 217 & 137 & 2.8 & 164 & 219 & 137 & 2.8 & 164 & 142 & 2.8 \\
\hline Separations & 574 & 633 & 93 & 86 & 574 & 621 & 93 & 86 & 574 & 98 & 86 \\
\hline Solidification & 442 & 283 & 134 & - & 442 & 283 & 134 & - & 442 & 178 & - \\
\hline $\begin{array}{l}\text { Acid } \\
\text { Recovery } \\
\end{array}$ & 57 & 68 & 1060 & - & 57 & 68 & 1060 & - & 57 & 1060 & - \\
\hline $\begin{array}{l}\text { Liquid } \\
\text { Effluent } \\
\text { Processing }\end{array}$ & 1272 & 1276 & 1295 & 3590 & 1272 & 1276 & 1295 & 3590 & 1272 & 1295 & 3573 \\
\hline Vitrification & 265 & 321 & 103 & 9.8 & 265 & 306 & 103 & 9.8 & 265 & 105 & 9.8 \\
\hline Off-gas & 12 & 12 & - & - & 12 & 12 & - & - & 12 & - & - \\
\hline $\begin{array}{l}\text { Balance of } \\
\text { Plant }\end{array}$ & 3337 & 3485 & 14 & 415 & 3337 & 3365 & 14 & 415 & 3337 & 15 & 415 \\
\hline Total & 6400 & 6527 & 2944 & 4103 & 7000 & 6981 & 3604 & 4975 & 6400 & 3002 & 4087 \\
\hline
\end{tabular}


Table 8.4. Estimated Secondary Waste Volumes $\left(\mathrm{m}^{3}\right)$ for MOX Fuel Fabrication (from Jones and Carter 2013)

\begin{tabular}{|l|c|c|c|}
\hline $\begin{array}{c}\text { Waste } \\
\text { Classification }\end{array}$ & UFD $^{\mathbf{a}}$ & AREVA $^{\mathbf{b}}$ & $\begin{array}{c}\text { Energy } \\
\text { Solutions }\end{array}$ \\
\hline Class A & - & 99 & 130 \\
\hline Class B & - & - & - \\
\hline Class C & - & - & - \\
\hline Total Class A/B/C & 510 & 99 & 130 \\
\hline GTCC & 2229 & 238 & 24 \\
\hline Mixed Class A/B/C & - & - & - \\
\hline Mixed GTCC & - & - & - \\
\hline Total & 2739 & 436 & 284 \\
\hline $\begin{array}{l}\text { a } 5.25 \mathrm{tPu} / \mathrm{y} \\
\mathrm{b} 9.3 \mathrm{tPu} / \mathrm{y}, 77.8 \mathrm{tU} / \mathrm{y} \\
\mathrm{c} 100 \mathrm{tHM} / \mathrm{y}\end{array}$ \\
\hline
\end{tabular}

Table 8.5. Estimated Secondary Waste Volumes $\left(\mathrm{m}^{3}\right)$ for Fast Reactor Fuel Fabrication (from Jones and Carter 2013)

\begin{tabular}{|l|c|c|}
\hline $\begin{array}{l}\text { Waste } \\
\text { Classification }\end{array}$ & AREVA $^{\mathbf{a}}$ & $\begin{array}{c}\text { Energy } \\
\text { Solutions }^{\mathbf{b}}\end{array}$ \\
\hline Class A & 70 & 66 \\
\hline Class B & - & - \\
\hline Class C & - & - \\
\hline Total Class A/B/C & 70 & 66 \\
\hline GTCC & 133 & 4.4 \\
\hline Mixed Class A/B/C & - & - \\
\hline Mixed GTCC & - & 4.7 \\
\hline Total & 203 & 75 \\
\hline $\begin{array}{l}\text { a } 7.0 \mathrm{tPu} / \mathrm{y}, 21 \mathrm{tU} / \mathrm{y} \\
{ }^{7} 40 \mathrm{tHM} / \mathrm{y}\end{array}$ \\
\hline
\end{tabular}

These secondary waste volumes were estimated without additional treatments to reduce volume or mass, just for the purpose of lowering storage, transportation, and disposal costs. A study was performed to evaluate how much the different classes of secondary waste could be reduced in volume and mass through waste treatment, for the purpose of determining if these waste treatments can lower the total secondary waste treatment, storage, and disposal costs (Jones 2013). The study estimated amounts of secondary wastes generated from recycling used $60 \mathrm{GWd} / \mathrm{tU}$ LWF fuel, cooled 5 years and 30 years, in an $800 \mathrm{tU} / \mathrm{yr}$ co-extraction reprocessing facility, both with and without added waste treatment to reduce storage, transportation, and disposal volumes. Features and results of this study include:

- Waste treatment processes that were considered for applicability to different secondary streams included compaction, solidification (stabilization via absorption, cementation, and other solidification), macroencapsulation, thermal desorption, and thermal treatment.

- Streams that were not amenable to volume-reduction treatment were not treated. Out of a total of 381 secondary waste streams, 297 were able to be volume-reduced in this study.

- Volume reduction resulted in raising the waste classification (for example, from Class A to Class $\mathrm{C}$, or from Class C to greater-than-class-C (GTCC) for some streams (13 streams for the 5-yrcooled fuel case, and 7 streams for the 30 -yr-cooled fuel case). 
- Even with the increases in the waste classification for some streams, the overall volume (and cost) for the different classes of wastes were reduced, as shown in Table 8.6. Through volumereducing treatments, the secondary waste volumes in the above tables could be cost-effectively reduced by an estimated volume average of about $3.5 \times$, although the different individual streams and waste classifications have higher and lower volume reductions.

- The total cost to treat, store, transport, and dispose secondary waste was estimate to be about $2 / 3$ of the cost to directly dispose the waste without volume-reduction treatments (recognizing that both the volume and cost estimates could vary with more specific and detailed estimates that should accompany any actual reprocessing facility designs).

Table 8.6. Estimated Used Fuel Reprocessing Secondary Waste Total Packaged Volume Reductions That Could Be Cost-Effective Considering Total Treatment, Storage, Transportation, and Disposal Costs.

\begin{tabular}{|l|c|c|}
\hline $\begin{array}{c}\text { Waste } \\
\text { Classification }\end{array}$ & $\begin{array}{c}\text { 5-year-cooled 60 GWd/tU fuel } \\
\text { Class A }\end{array}$ & 30-year-cooled 60 GWd/tU fuel \\
\hline Class B & 4.8 & 4.8 \\
\hline Class C & $\begin{array}{c}0.99 \text { (1.01x volume increase as required to } \\
\text { meet transportation or disposal } \\
\text { requirements) }\end{array}$ & 1.0 (no volume change) \\
\hline GTCC & 3.0 & 2.4 \\
\hline Mixed Class A & 4.4 & 4.8 \\
\hline Mixed Class B & 1.1 & 1.6 \\
\hline Mixed Class C & 1.9 & 3.6 \\
\hline Mixed GTCC & 1.6 & 1.6 \\
\hline Total & $\begin{array}{c}0.63 \text { (1.6x volume increase as required to } \\
\text { meet transportation or disposal } \\
\text { requirements) }\end{array}$ & $\begin{array}{c}0.63 \text { (1.6x volume increase as required to meet } \\
\text { transportation or disposal requirements) }\end{array}$ \\
\hline
\end{tabular}

\subsection{Data Gaps and Research Needs}

The estimated cost to transport and dispose of GTCC waste is at least 2-3 times higher than the cost for any other waste classification. Treatment of GTCC waste prior to disposal significantly reduces the final cost of disposal. This suggests there could be benefit if some research and development, policy changes, etc. were focused on GTCC waste. 


\section{CEMENTATION OF COMBINED WASTE STREAMS}

A number of waste streams can be combined into a cement waste form or cemented separately including tritium. The streams of interest are generally LLWs and the decision on if they should be combined is dependent on their radionuclide concentrations, specific processing requirements, and disposal class. For the purposes of the waste volume summary for representative reprocessing flowsheets in this report, the streams that are destined to cementation will be combined into a single stream and cemented for ultimate disposal. The radionuclide inventory estimates will ultimately determine their disposal class or will point for the need to optimize the waste generation, treatment, and disposal for selected streams. The primary streams to be cemented include:

- evaporated salt wastes from solvent cleanup (the lower contamination fraction not needed for HLW glass making)

- decanted $\mathrm{CaCO}_{3}$ slurry from ${ }^{14} \mathrm{C}$ capture

- tritiated water from ${ }^{3} \mathrm{H}$ capture of the TPT gas stream (if used)

- concentrated tritiated water from routine purge of water recycle after ${ }^{3} \mathrm{H}$ concentration (in the reference flowsheet)

Different cement formulations are used for different waste streams. However the most compositionally challenging formulations are associated with the immobilization of high salt wastes. Examples of the cements formulated for salt-stone at the Savannah River Site and Cast Stone (a containerized version of cement for a similar low-activity waste stream) proposed for use at the Hanford Site were used to estimate soda loading in cement (Cozzi 2005; Cozzi et al. 2011; Langton 1985; Serne and Westsik 2011; Westsik et al. 2013). The cement formulations for high soda streams are summarized in Table 9.1. The target and maximum [Na] for saltstone are 6.0 and $6.44 \underline{\mathrm{M}}$, respectively, while the maximum [Na] for caststone is $7.8 \underline{\mathrm{M}}$. Both formulations use a six parts of free water to ten parts of dry additives blend and generate waste forms with densities between 1.8 and $2.0 \times 10^{3} \mathrm{~kg} / \mathrm{m}^{3}$. The similarities in these compositions suggest that an average composition be used for this study.

Table 9.1. High-Soda Cement Blend Formulations, dry mass\%

\begin{tabular}{|l|c|c|c|}
\hline \multicolumn{1}{|c|}{ Formulation } & Salt-stone & Cast Stone & Recommended \\
\hline Ordinary Portland Cement (OPC) & 10 & 8 & 9 \\
\hline Fly Ash (FA) & 45 & 45 & 45 \\
\hline Blast Furnace Slag (BFS) & 45 & 47 & 46 \\
\hline Target [Na], $\underline{M}$ & 6.0 & 7.8 & 6.9 \\
\hline Free water per unit dry additives (by mass) & 0.6 & 0.6 & 0.6 \\
\hline
\end{tabular}

Cements for high soda waste have also been used to simultaneously microencapsulate solid wastes with solid contents of up to 30 mass\% (Zakharova et al. 2007). In this case, the encapsulated solid is not fully described but is listed only as dry residue from concentrate bottoms of nuclear power plant operating wastes. The Chinese encapsulate 21 to 35 mass\% ion exchange resin (on a dry basis) in high soda cement formulations (IAEA 2013).

In the UK, BNFL encapsulates the following in 9:1 BFS and OPC mixtures occasionally with additional $\mathrm{NaOH}$ : fine and coarse magnox sludge, bead and granular phenolformaldehyde resin, ammoniated divinylbenzene resin, inorganic filter media and aids, granular carbon, inorganic ion exchange material, magnox alloy splitters, borated wastes such as ion exchange resins, PWR primary ion exchange resin, silica gel resin, and PWR wastes such as boric acid concentrate (Streatfield 2001). 
The South Africans immobilize tritium in mixtures of OPC and vermiculite (50:50 and 70:30), asphalt (70:30), bitumen (70:30), lime (90:10), fumed silica (70:30), and BFS (70:30) (IAEA 2014). Some of these cement mixtures immobilize tritium and simultaneously encapsulate between 10 and 30 mass\% of graphite dust, sludges, loaded chabazite and loaded resorcinol formaldehyde (RF) resin (IAEA 2014).

It is premature to determine if the cement waste forms for individual streams (tritiated water, $\mathrm{CaCO}_{3}$, salt wastes, and various additional liquid and solid secondary wastes) should be segregated and immobilized separately. So, in this study a single cement waste form is assumed. This waste form is used to immobilize sodium solutions at [Na] of $6.9 \underline{\mathrm{M}}, 30$ mass $\%$ dry solid encapsulate (including $\mathrm{CaCO}_{3}$ ), and 30 mass $\%$ tritiated water. The resulting cement waste form is summarized in Table 9.2. The evaporated solvent wash and high volume tritiated water streams dominate the cement generated. The $\mathrm{CaCO}_{3}$ could be combined with either of these streams that are limited by total water volume $(0.6 \mathrm{~kg}$ water $/ \mathrm{kg}$ cement for solvent wash and $0.3 \mathrm{~kg}$ tritiated water $/ \mathrm{kg}$ cement) while $\mathrm{CaCO}_{3}$ is limited by 30 mass\% solid inclusions). Additional solid secondary waste can also be included in the cement for evaporated solvent wash or high volume tritiated water.

Because tritiated water is one of the streams being immobilized, care must be taken to avoid evaporative losses to high-volume off-gas streams, thereby creating a very much larger gas volume to treat. Therefore an in-drum, cementation process, such as MOSS described in Section 7.2, is recommended. The cement is assumed to generate a waste form that fills $90 \%$ of the drum volume and have a density of roughly 1.9 $\times 10^{3} \mathrm{~kg} / \mathrm{m}^{3}$.

Table 9.2. Summary of Cement Waste Form Volume and Mass

\begin{tabular}{|l|c|c|c|c|c|c|}
\hline Stream & $\begin{array}{c}\text { Total flow, } \\
\mathbf{k g} / \mathbf{t U}\end{array}$ & $\begin{array}{c}\mathbf{~ N a} \\
\mathbf{M o l} / \mathbf{L}\end{array}$ & $\begin{array}{c}\mathbf{C a C O}_{3} \\
\mathbf{k g} / \mathbf{t U}\end{array}$ & $\begin{array}{c}\text { Solvent, } \\
\mathbf{k g} / \mathbf{t U}\end{array}$ & $\begin{array}{c}\text { Cement WF } \\
\mathbf{k g} / \mathbf{t U}\end{array}$ & $\begin{array}{c}\text { Cement WF } \\
\text { volume, } \mathbf{~ m}^{\mathbf{3}} / \mathbf{y}\end{array}$ \\
\hline $\begin{array}{l}\text { Evaporated solvent } \\
\text { wash }\end{array}$ & 1564 & 0.4 & 26.5 & 313 & 2600 & 1370 \\
\hline $\mathbf{C a C O}_{3}$ & 39.5 & 1.6 & 20.4 & 0 & 81 & 43 \\
\hline Tritiated water & & & & & & \\
\hline TPT off-gas & 0.02 & 0 & 0 & 0 & 0.07 & 0.035 \\
\hline $\begin{array}{l}\text { High volume } \\
\text { water }\end{array}$ & 5000 & 0 & 0 & 0 & 16700 & 8770 \\
\hline Optimized water & 300 & 0 & 0 & 0 & 1000 & 526 \\
\hline $\begin{array}{l}\text { Enriched high } \\
\text { volume water }\end{array}$ & 5 & 0 & 0 & 0 & 16.7 & 8.77 \\
\hline
\end{tabular}

\subsection{Data Gaps and Research Needs}

- Cementation is a mature technology. Cement performance modeling and measurements is the subject of an ongoing U.S. research effort (see for example IAEA 2013). Application of the results of these studies will ultimately be important to the success of cementation for closed U.S. fuel cycles. Formulation of low-water cements specifically for the combined waste streams from a closed fuel cycle will be necessary along with process demonstrations.

- Solvent wash solution waste is a very high volume waste stream and optimization of the wash process and perhaps other methods to manage the waste stream should be evaluated to minimize the volume of cement waste form generated. 


\section{SUMMARY AND CONCLUSIONS}

This study evaluates waste management approaches for nuclear fuel cycle facilities in comparison to the objectives of implementing an advanced fuel cycle in the U.S. under current legal, regulatory, and logistical constructs. The study rests heavily on the GNEP IWMS (Gombert et al. 2008) as a general strategy and associated WTBS (Gombert et al. 2007). The approaches used in the IWMS are equally valid to the current waste management study. However, the flowsheet details have changed significantly from those considered under GNEP. In addition, significant additional waste management technology development has occurred since the GNEP waste management studies were performed. This study updates the information found in the WTBS, summarizes the results of more recent technology development efforts, and describes waste management approaches as they apply to reasonable example reprocessing flowsheets. Many of the waste management technologies discussed also apply to other potential flowsheets that involve reprocessing. These applications have been discussed where the data are more readily available.

The report summarizes the waste arising from aqueous reprocessing of a typical light-water reactor (LWR) fuel to separate actinides for use in fabricating metal SFR fuel and from electrochemical reprocessing of the metal SFR fuel to separate actinides for recycle back into the SFR in the form of metal fuel. The primary streams considered and the recommended waste forms include:

- Tritium separated from either a low volume gas stream or a high volume water stream. The recommended waste form is low-water cement in HICs.

- Iodine-129 separated from off-gas streams in aqueous processing. There are a range of potentially suitable waste forms. The reference case is a GCM formed by the encapsulation of the AgZ getter material in a low-temperature glass. A number of alternatives with distinct advantages are also considered, including a fused silica waste form with encapsulated nano-sized AgI crystals.

- Carbon-14 separated from LWR fuel treatment off-gases and immobilized as $\mathrm{CaCO}_{3}$ in a cement waste form.

- Krypton-85 separated from LWR and SFR fuel treatment off-gases and stored as a compressed gas.

- An aqueous reprocessing HLW raffinate waste which is immobilized by the vitrification process in one of three forms: a single phase borosilicate glass, a borosilicate based glass ceramic, or a multi-phased crystalline ceramic (e.g. Synroc).

- An UDS fraction from aqueous reprocessing of LWR fuel that is either included in the borosilicate HLW glass or is immobilized in the form of a metal alloy if glass ceramics or titanate-based ceramics are used as the HLW raffinate waste form.

- Zirconium-based LWR fuel cladding hulls and SS fuel assembly hardware that are washed and super-compacted for disposal or purified by reactive gas separations and either reused or disposed as LLW.

- Electrochemical process salt HLW which is incorporated into a glass bonded sodalite waste form known as the CWF.

- Electrochemical process UDS and SS cladding hulls which are melted into an iron-based alloy waste form.

Mass and volume estimates for each of the recommended waste forms based on the source terms are reported. The resulting waste form masses and volumes are summarized in Table 10.1 for LWR fuel and Table 10.2 for FR fuel. 
Table 10.1. Estimated Reprocessing Waste Masses and Volumes for a 1000 tU/y Aqueous Used Fuel Reprocessing Facility (50 GW/tU burnup LWR fuel).

\begin{tabular}{|l|l|r|r|l|}
\hline Stream & Waste form & $\begin{array}{r}\text { Mass, } \\
\mathbf{k g} / \mathbf{t U}\end{array}$ & $\begin{array}{r}\text { Vol, } \\
\mathbf{L} / \mathbf{t}\end{array}$ & Comment \\
\hline Tritium & & & & \\
\hline TPT off-gas & low water cement & 0.07 & 0.035 & water:cement ratio of 0.3 \\
\hline High volume water & low water cement & 16700 & 8770 & water:cement ratio of 0.3 \\
\hline Optimized water & low water cement & 1000 & 526 & water:cement ratio of 0.3 \\
\hline Isotope enriched & low water cement & 16.7 & 8.77 & water:cement ratio of 0.3 \\
\hline Iodine & & & & \\
\hline AgZ & glass composite material & 100 & 24.5 & total halogen:I ratio rounded to 3 \\
\hline AgAero & fused silica-AgI & 3.66 & 1.22 & total halogen:I ratio rounded to 3 \\
\hline Krypton & Low pressure gas & 0.646 & $3.7 \times 10^{-3}$ & 50 atm \\
\hline & High pressure gas & 0.646 & $1.1 \times 10^{-3}$ & 163 atm \\
\hline & Zeolite & 0.646 & $2.8 \times 10^{-3}$ & HIP \\
\hline & Metal matrix & 0.646 & $7.8 \times 10^{-4}$ & Cu matrix \\
\hline Carbon & Cement & 81 & 43 & water:cement ratio of 0.3 \\
\hline High level waste & & & & \\
\hline LNFP+TMFP+UDS+Tc & Borosilicate glass & 401 & 154 & 5 y cooled fuel \\
\hline LNFP+TMFP+UDS+Tc & Borosilicate glass & 302 & 116 & 50 y cooled fuel \\
\hline LNFP+TMFP & Glass ceramics & 214 & 70 & 5 y cooled fuel \\
\hline LNFP+TMFP & Glass ceramics & 76 & 25 & 50 y cooled fuel \\
\hline LNFP+TMFP & Titanate ceramics & 173 & 38 & \\
\hline UDS+Tc & e-metal & 9.71 & 0.81 & \\
\hline UDS+Tc & Fe-metal & 19.4 & 2.43 & \\
\hline Hulls and Hardware & & & & \\
\hline Hulls + Hardware & Supercompacted & 301 & 67.6 & $66 \%$ volume \\
\hline Hardware only & Supercompacted & 47 & 8.9 & $66 \%$ volume \\
\hline Zr recycle & Recycled & & & wastes TBD \\
\hline
\end{tabular}

Table 10.2. Estimated Reprocessing Waste Masses and Volumes for a $20 \mathrm{tU} / \mathrm{y}$ Electrochemical Used Fuel Reprocessing Facility (100 GW/tHM burnup SFR fuel).

\begin{tabular}{|c|c|c|c|c|}
\hline Stream & Waste form & $\begin{array}{r}\text { Mass, } \\
\mathrm{kg} / \mathrm{tHM}\end{array}$ & $\begin{array}{r}\text { Vol, } \\
\text { L/tHM }\end{array}$ & Comment \\
\hline \multirow[t]{3}{*}{ HLW Salt } & CWF Nominal & 2,700 & 1,280 & 25 mass $\%$ BSG, 0 mass $\%$ Halite \\
\hline & High-loaded CWF & 1,740 & 980 & 20 mass $\%$ BSG, 2.5 mass $\%$ Halite \\
\hline & $\mathrm{TeO}_{2}$-based glass & 3,920 & 810 & Density $4,830 \mathrm{~kg} / \mathrm{m}^{3}$ \\
\hline Ducts, Plenums, etc... & Supercompacted & 3,310 & 630 & $66 \%$ volume \\
\hline Hulls and noble metals & Melted Fe-metal & 530 & 67 & \\
\hline \multirow[t]{4}{*}{ Krypton } & Low pressure gas & 0.688 & $3.94 \times 10^{-3}$ & $50 \mathrm{~atm}$ \\
\hline & High pressure gas & 0.688 & $1.17 \times 10^{-3}$ & $163 \mathrm{~atm}$ \\
\hline & Zeolite & 0.688 & $2.98 \times 10^{-3}$ & HIP \\
\hline & Metal matrix & 0.688 & $8.31 \times 10^{-4}$ & Cu matrix \\
\hline
\end{tabular}

In addition to the above listed primary waste streams, a range of secondary process wastes are generated by aqueous reprocessing of LWR fuel, metal SFR fuel fabrication, and electrochemical reprocessing of SFR fuel. These secondary wastes have been summarized and volumes estimated by type and classification.

The important waste management data gaps and research needs have been summarized for each primary waste stream and selected waste process. 


\section{REFERENCES}

10 CFR 20. Standards for Protection against Radiation, U.S. Nuclear Regulatory Commission, Washington, D.C.

10 CFR 61. Licensing Requirements for Land Disposal of Radioactive Waste, U.S. Nuclear Regulatory Commission, Washington, D.C.

40 CFR 168. Land Disposal Restrictions, U.S. Environmental Protection Agency, Washington, D.C.

40 CFR 190. Environmental Radiation Protection Standards for Nuclear Power Operations, U.S. Environmental Protection Agency, Washington, D.C.

Abraham, D.P., S.M. Mcdeavitt, and J. Park. 1996. "Microstructure and Phase Identification in Type 304 Stainless Steel-Zirconium Alloys," Metall. Mater. Trans. A, 27A(8):2151-2159. 10.1007/BF02651870.

Abraham, D.P., J.W. Richardson, Jr., and S.M. McDeavitt. 1997. "Laves Intermetallics in Stainless SteelZirconium Alloys," Mater. Sci. Eng., A, A239-240:658-664. 10.1016/S0921-5093(97)00649-7.

Abraham, D.P., S.M. McDeavitt, D.D. Keiser, S.G. Johnson, M.L. Adamic, S.A. Barker, T.D. Disanto, S.M. Frank, J.R. Krsul, M. Noy, J.W. Richardson, and B.R. Westphal. 1999. Metal Waste Form Handbook, ANL-NT-121, Argonne National Laboratory, Argonne, IL.

Ackerman, J.P., T.R. Johnson, L.S.H. Chow, E.L. Carls, W.H. Hannum, and J.J. Laidler. 1997. "Treatment of Wastes in the Ifr Fuel Cycle," Progress in Nuclear Energy, 31(1/2):141-154.

Adachi, T., M. Ohnuki, N. Yoshida, T. Sonobe, W. Kawamura, H. Takeishi, K. Gunji, T. Kimura, T. Suzuki, and A. et. 1990. "Dissolution Study of Spent PWR Fuel: Dissolution Behavior and Chemical Properties of Insoluble Residues," J. Nucl. Mater., 174(1):60-71. 10.1016/0022-3115(90)90421-I.

AFCF. 2007. Product Solidification, Waste Solidification, and Off-Gas Unit Operations Mass Balance Basis, GNEP-AFCF-WAST-PC-RT-2007-000332, Advanced Fuel Cycle Facility Project, Idaho Falls, ID.

Ahn, D.-H., S. Paek, H.-J. Choi, K.-R. Kim, H. Chung, S.P. Yim, and M.S. Lee. 2006. "Development of Water Detritiation Process Using the Hydrophobic Platinum Catalyst," Waste Management 2006, Tucson, AZ.

Alfimov, V., A. Aldahan, G. Possnert, and P. Winsor. 2004. "Anthropogenic iodine-129 in seawater along a transect from the Norwegian coastal current to the North Pole," Marine Pollution Bulletin, 49:10971104.

Amaury, P. 1980. "Solidification and Storage of High Activity Nuclear Waste from Reprocessing: The AVM Process," Uranium Nucl. Energy, 4:193-201.

Amoroso, J., J.C. Marra, M. Tang, Y. Lin, F. Chen, D. Su, and K.S. Brinkman. 2014a. "Melt Process Multiphase Ceramic Waste Forms for Nuclear Waste Immobilization," Journal of Nuclear Materials, 454(1-3).

Amoroso, J., J. Marra, S.D. Conradson, M. Tang, and K. Brinkman. 2014b. "Melt Processed Single Phase Hollandite Waste Forms for Nuclear Waste Immobilization: $\mathrm{Ba}(1.0) \mathrm{Cs}(0.3) \mathrm{A}(2.3) \mathrm{Ti}(5.7) \mathrm{O}(16) ; \mathrm{A}=\mathrm{Cr}$, $\mathrm{Fe}, \mathrm{Al}, "$ Journal of Alloys and Compounds, 584:590-599. DOI 10.1016/j.jallcom.2013.09.087. 
Andreev, B.M., E.P. Magomedbekov, A.A. Raitman, M.B. Pozenkevich, Y.A. Sakharovsky, and A.V. Khoroshilov. 2007. Separation of Isotopes of Biogenic Elements in Two-Phase Systems. Elsevier, Amsterdam, The Netherlands.

Areva. 2013. Task 9 Report - Improving the Estimates of Waste from Recycling, Sub-Task 5: Final Technical Report, RPT-3007827-001, AREVA Federal Services, Charlotte, NC.

ASTM. 2008. Standard Test Method for Determining the Chemical Durability of Nuclear Waste Glasses: The Product Consistency Test (PCT), ASTM C1285 - 02(2008), American Society for Testing and Materials, West Conshohocken, Pennsylvania.

Atkins, M. and F.P. Glasser. 1990. "Encapsulation of Radioiodine in Cementitious Waste Forms," Scientific Basis for Nuclear Waste Management XIII, Vol. Materials Research Society Symposium Proceedings, Vol. 176, 15-22 pp. Materials Research Society, Pittsburgh, PA.

Atkins, M., A. Kindness, F.P. Glasser, and I. Gibson. 1990. "The Use of Silver as a Selective Precipitant for ${ }^{129} \mathrm{I}$ in Radioactive Waste Management," Waste Management, 10:303-308.

Baetsle, L.H. and J. Broothaerts. 1977. "Reprocessing Off-Gas Treatment Research in Belgium." In Seminar on Radioactive Effluents from Nuclear Fuel Reprocessing Plants. Schule für Kerntechnik Kernforschungszentrum, Karlsruhe, Germany.

Bakel, A.J., D.L. Bowers, K.J. Quigley, M.C. Regalbuto, J.A. Stillman, and G.F. Vandegrift. 2006. "Dissolution of Irradiated Nuclear Fuel from the Big Rock Point Reactor." In Separations for the Nuclear Fuel Cycle in the $21^{\text {st }}$ Century, Vol 933, pp. 71-88. American Chemical Society, Washington, DC.

Balls, V.J. and R.C. Williams. 2011. Letter, "Use of Existing IWTU Hot Cells for Cdp HIP Treatment of HLW Calcine White Paper," to Idaho Cleanup Project, Idaho Falls, ID.

Barnert-Wiemer, H. and E. Merz. 1977. "Off-Gas Treatment in HTR Fuel Reprocessing," in Seminar on Radioactive Effluents from Nuclear Fuel Reprocessing Plants, AED-CONF-77-473-027, Karlsruhe, Germany.

Bateman, K.J. and C.W. Solbrig. "Using Center Hole Heat Transfer to Reduce Formation Times for Ceramic Waste Forms from Pyroprocessing," 14th International Conference on Nuclear Engineering, ICONE14, Paper number 89794, Miami, FL.

Bateman, K.J., C.J. Knight, and C.W. Solbrig. 2007. Current Status of Ceramic Waste Form Development, INL/INT-06-11736, Rev. 1, Idaho National Laboratory, Idaho Falls, ID.

Bendixsen, C.L. and F.O. German. 1971. Operation of the ICPP Rare Gas Recovery Facility During Fiscal Year 1970, Allied Chem. Corp., Idaho Chemical Processing Plant, Idaho Falls, ID.

Bendixsen, C.L., F.O. German, and R.R. Hammer. 1973. 1972 Operation of the ICPP (Idaho Chemical Processing Plant) Rare Gas Recovery Facility, Allied Chem. Corp., Idaho Chemical Processing Plant, Idaho Falls, ID.

Bendixsen, C.L. and D.A. Knecht. 1976. Separation and Storage of Krypton. In Proceedings NTIS, 
Bendixsen, C.L., G.F. Offutt, and B.R. Wheeler. 1971. "Cryogenic Rare Gas Recovery in Nuclear Fuel Reprocessing," Chem. Eng. (New York), 78(22):55-57.

Bernadzikowski, TA, JS Allender, DE Gordon, TH Gould Jr, and JA Stone. 1982. The Development, Evaluation, and Selection of Candidate High-Level Waste Forms, DP-MS-82-47, Savannah River laboratory, Aiken, SC.

Bernardo, E., M. Varrasso, F. Cadamuro, and S. Hreglich. 2006. "Vitrification of wastes and preparation of chemically stable sintered glass-ceramic products," Journal of Non-Crystalline Solids, 352:4017-4023.

Birdwell, J.F. 1990. "Iodine and $\mathrm{NO}_{\mathrm{x}}$ Behavior in the Dissolver Off-Gas and IODOX Systems in the Oak Ridge National Laboratory Integrated Equipment Test Facility," the $21^{\text {st }}$ DOE/NRC Nuclear Air Cleaning Conference, US Department of Energy, Washington, DC.

Boen, R., C. Ladirat, M. Bonnal, and D. Delage. 1998. "Fusion De Verre Par Induction En Creuset Froid: Perspectives D'applications Industrielles Exemples D'utilisation De La Technologie À L'élaboration Des Émaux," International Conference on Electromagnetic Processing of Materials (EMP) 1997, Paris,

France.

Bohnenstingl, J., M. Heidendael, M. Laser, S. Mastera, and E. Merz. 1976. "Cryogenic Separation of Krypton and Xenon from Dissolver Off-Gas," in Proceedings of Symposium on The Management of Radioactive Wastes from the Nuclear Fuel Cycle, IAEA, p. 129-137, ISBN 92-0-020276-4, Vienna, Austria.

Bonnetier, A., J.F. Hollebecque, J. Lacombe, R. Do Quang, and P. Rivat. 2003. "Development of an Advanced Cold Crucible for Direct Induction Melting of Glass," 4th International Conference on Electromagnetic Processing of Materials, Lyon, France.

Bonnett, I., A. Busigin, and A. Shapiro. 2008. "Tritium Removal and Separation Technology Developments," Fusion Sci. Technol., 54(1):209-214.

Bonniaud, R., C. Sombret, and A. Barbe. 1976. "Continuous Vitrification of Radioactive-Wastes," Chemical Engineering Progress, 72(3):47-48.

Bonniaud, R., C. Sombret, L. Rozand, A. Barbe, P. Auchapt, and J.A. Coste. 1976. "French Industrial Plant AVM for Continuous Vitrification of High Level Radioactive Wastes," AIChE Symp. Ser., 72(154, Radioact. Wastes Nucl. Fuel Cycle):145-150.

Bonniaud, R.A., A.F. Jouan, and C.G. Sombret. 1979. "Status of the French AVM Vitrification Facility," in Waste Management 1979, Tucson, AZ.

Borisov, G.B., A.S. Polyakov, and O.A. Mansourov. 1999. "Safety Issues of Russian Ep-500 Ceramic Melter and the Feasibility of Its Usage to Vitrify Pu-Containing Materials," Nuclear Materials Safety Management Vol II, 27:85-94.

Braase, L. and W.E. May. 2014. Material Recovery and Waste Form Development FY 2014 Accomplishments Report, FCRD-MRWFD-2015-00004, Idaho National Laboratory, Idaho Falls, ID.

Bray, G.R. 1977. Assessment of Carbon-14 Control Technology and Costs for the LWR Fuel Cycle, Environmental Protection Agency, Washington, DC. 
Brown, R.A., J.D. Christian, and T.R. Thomas. 1983. Airborne Radionuclide Waste Management Reference Document, ENICO-1133, Exxon Nuclear Idaho Company, Idaho Falls, ID.

Bruffey, S.H., K.K. Anderson, R.T. Jubin, and J.F. Walker. 2012. Aging and Iodine Loading of SilverFunctionalized Aerogels, FCRD-SWF-2012-000256, Oak Ridge National Laboratory, Oak Ridge, TN.

Bruffey, S.H., K.K. Anderson, J.F. Walker, and R.T. Jubin. 2013. Humid Aging and Iodine Loading of Silver Functionalized Aerogels, FCRD-SWF-2013-000258, Oak Ridge National Laboratory, Oak Ridge, TN.

Bruffey, S.H., J.F. Walker, R.T. Jubin, and K.K. Anderson. 2013b. Dry Air Aging of Iodine-Loaded Silver Mordenite, FCRD-SWF-2013-000259, Oak Ridge National Laboratory, Oak Ridge, TN.

Bruffey, S.H., R.T. Jubin, K.K. Anderson, and J.F. Walker. 2014. Aging of Iodine-Loaded Silver Mordenite in $\mathrm{NO}_{2}$, FCRD-SWF-2014-000465, Oak Ridge National Laboratory, Oak Ridge, TN.

Buhl, J.-C. 1996. "The Properties of Salt-Filled Sodalites. Part 4. Synthesis and Heterogeneous Reactions of Iodate-Enclathrated Sodalite $\mathrm{Na}_{8}\left[\mathrm{AlSiO}_{4}\right]_{6}\left(\mathrm{IO}_{3}\right)_{2}-\mathrm{X}\left(\mathrm{OH}, \mathrm{H}_{2} \mathrm{O}\right)_{\mathrm{X}} ; 0.7<\mathrm{X}<1.3$," Thermochim. Acta, 286(2):251-262. 10.1016/0040-6031(96)02971-1.

Burch, W.D., O.O. Yarbro, W.S. Groenier, and M.J. Stephenson. 1976. Retention of Gaseous Fission Products in Reprocessing LMFBR Fuels, IAEA-AG-63-2, International Atomic Energy Agency, Vienna, Austria.

Burger, L.L. and R.D. Scheele. 1983. The Status of Radioiodine Control for Nuclear Fuel Reprocessing Plants, PNL-4689, Pacific Northwest Laboratory, Richland, WA.

Burger, L.L., R.D. Scheele, and K.D. Weimers. 1981. Selection of a Form for Fixation of Iodine-129, PNL-4045, Pacific Northwest Laboratory, Richland, WA.

Carter, M.L., H.J. Li, Y.J. Zhang, A.L. Gillen, and E.R. Vance. 2009. "Hiped Tailored Pyrochlore-Rich Glass-Ceramic Waste Forms for the Immobilization of Nuclear Waste," Scientific Basis for Nuclear Waste Management XXXII, Vol. 1124, 195-206 pp. Materials Research Society.

Casa, A.F. 1977. "Treatment of Gaseous Wastes from Reprocessing Plants," Not. Com. Naz. Energ. Nucl. (Italy), 23(2):71-75.

CFTC. 2008. Follow-on Engineering Alternative Studies Summary Report, GNEP-CFTC-PMO-MI-DV2008-00087, Consolidated Fuel Treatment Center, Aiken, SC.

Chang, S.D., C.H. Cheh, and P.J. Leinonen. 1991. Demonstration of Carbon-14 Removal at CANDU Nuclear Generating Stations, 0270-6482, Ontario Hydro, Ontario, Canada.

Cheh, C.H. 1985. "Removal of Carbon-14 from Nitrogen Annulus Gas," in Proceedings of the 18th DOE Nuclear Air Cleaning Conference, Vol. 2:1283-1299.

Chen, L. Reiss, P. S. Chong, S. Y. Holden, D. Jelfs, K. E. Hasell, T.Little, M. A.Kewley, A. Briggs, M. E. Stephenson, A. Thomas, K. M. Armstrong, J. A. Bell, J. Busto, J. Noel, R. Liu, J. Strachan, D. M. Thallapally, P. K. Cooper, A. I. 2014. Separation of rare gases and chiral molecules by selective binding in porous organic cages, Nature Materials, 13, 954-960. 
Chesne, A., P. Miquel, J.P. Goumondy, and A. Leseur. 1977. "Progress Report on French Research and Development in the Treatment of Off-Gases from Reprocessing Plants." In Seminar on Radioactive Effluents from Nuclear Fuel Reprocessing Plants. Schule für Kerntechnik Kernforschungszentrum, Karlsruhe, Germany.

Cheung, C.K.W., E.R. Vance, M.W.A. Stewart, D.R.M. Brew, W. Bermudez, T. Eddowes, and S. Moricca. 2012. "The Intermediate Level Liquid Molybdenum-99 Waste Treatment Process at the Australian Nuclear Science and Technology Organisation," ATALANTE 2012, Procedia Chemistry.

Chick, L.A., W.M. Bowen, R.O. Lokken, J.W. Wald, L.R. Bunnell, and D.M. Strachan. 1984. West Valley High-Level Nuclear Waste Glass Development: A Statistically Designed Mixture Study, PNL4992, Pacific Northwest National Laboratory, Richland, Washington.

Chick, L.A., R.O. Lokken, D.M. Strachan, and W.M. Bowen. 1986. "Development of a West Valley Nuclear Waste Glass by Empirical Modeling," Bulletin of the American Ceramic Society, 65(2):114-118.

Cho, Y.Z., H.C. Yang, H.C. Eun, E.H. Kim, and I.T. Kim. 2006. "Characteristics of Oxidation Reaction of Rare-Earth Chlorides for Precipitation in LiCl-KCl Molten Salt by Oxygen Sparging" Nuclear Science and Technology, 43(10):1280-1286.

Choi, B.K. and K.H. Shin. 1996. "Ionic conductivity and Raman spectroscopic investigations of $\mathrm{B}_{2} \mathrm{O}_{3}$ $\mathrm{Na}_{2} \mathrm{O}-\mathrm{Na}_{2} \mathrm{I}_{2}$ glasses," Physics and Chemistry of Glasses, 37 (3):87-91.

Choi, J.H., I.H. Cho, H.C. Eun, H.S. Park, Y.Z. Cho, K.R. Lee, G.I. Park, S.H. Kim, C.H. Shin, and J.K. Kim. 2014. "Fabrication and Physical Properties of Lanthanide Oxide Glass Wasteform for the Immobilization of Lanthanide Oxide Wastes Generated from Pyrochemical Process" Journal of Radioanalytical and Nuclear Chemistry, 299:1731-1738. DOI: 10.1007/s10967-013-2863-6.

Chowdari, B.V.R., K.L. Tan, and F. Ling. 1998. "Characterization of $\mathrm{xCuI} \cdot(50-\mathrm{x}) \mathrm{AgI} \cdot \mathrm{yCu}_{2} \mathrm{MoO}_{4} \cdot(50-\mathrm{y}) \mathrm{CuPO}_{3}$ glasses," Solid State Ionics, 107(1-2):89-103. DOI: 10.1016/s0167-2738(97)00521-3.

Chowdari, B.V.R., K.L. Tan, and F. Ling. 2000. "Synthesis and characterization of $\mathrm{Cu}_{2} \mathrm{O} \cdot \mathrm{TeO}_{2}$ and $\mathrm{CuI} \cdot \mathrm{Cu}_{2} \mathrm{O} \cdot \mathrm{TeO}_{2}$ glasses," J. Mater. Sci., 35:2015-2027.

Clark, W.E. 1977. "The Isolation of Radioiodine with Portland Cement Part 1: Scoping Leach Studies," Nuclear Technology, 36:215-221.

Clark, W.E., W.B. Howerton, B.M. Benjamin, and W.H. Baldwin. 1978. "The Oxidation and Degradation of Short-Chain Aliphatic Compounds by Hyperazeotropic Nitric Acid," Nucl. Sci. Eng., 66(1):110-117.

Clark, W.E. and C.T. Thompson. 1977. "Immobilization of Iodine in Concrete," U.S. Patent No. $4,017,417$.

Collard, G.E.R., L.P.M. Geens, P.J. Vaesen, and W.R.A. Goossens. 1981a. "Experimental Development and Design Aspects of a Krypton-85 Removal Distillation Unit," in Proceedings of the $16^{\text {th }}$ DOE Nuclear Air Cleaning Conference, Vol. 2, pp. 1072-1082.

Collard, G.E.R., D. Hennart, J. Van Dooren, and W.R.A. Goossens. 1981b. "Iodine Trapping and Conditioning in the Mercurex System," in Proceedings of the $16^{\text {th }}$ DOE Nuclear Air Cleaning Conference, Vol. 1, pp. 552-565. 
Collins, E.D. and D.E. Benker. 1979. Iodox Process Tests in a Transuranium Element Production Campaign, ORNL/TM-6182, Oak Ridge National Laboratory, Oak Ridge, TN.

Cozzi, A.D. 2005. Properties of Saltstone Prepared Containing H-Canyon Waste, WSRC-TR-200500149, Savannah River National Laboratory, Aiken, SC.

Cozzi, A.D., E.K. Hansen, T.M. Jones, and Y.R. Safford. 2011. Bench Scale Saltstone Process Development Mixing Study, SRNL-STI-2011-00346, Savannah River National Laboratory, Aiken, SC.

Cristescu, I., I.R. Cristescu, L. Dorr, M. Glugla, D. Murdoch, and S. Welte. 2006. "Long Term Performances Assessment of a Water Detritiation System Components," Fusion Engineering and Design, 81(1-7):839-844. DOI 10.1016/j.fusengdes.2005.07.027.

Croff, A.G. 1983. "ORIGEN2 - A Versatile Computer Code for Calculating the Nuclide Compositions and Characteristics of Nuclear-Materials," Nuclear Technology, 62(3):335-352.

Crum, J.V., D.M. Strachan, and M. Zumhoff. 2012a. Initial Evaluation of Processing Methods for an Epsilon Metal Waste Form, FCR\&D-SWF-2012-000108, Pacific Northwest National Laboratory, Richland, WA.

Crum, J.V., L. Turo, B.J. Riley, M. Tang, and A. Kossoy. 2012b. "Multi-Phase Glass-Ceramics as a Waste Form for Combined Fission Products: Alkalis, Alkaline Earths, Lanthanides, and Transition Metals," Journal of the American Ceramic Society, 95(4):1297-1303.

Crum, J.V., C.P. Rodriguez, J.S. Mccloy, J.D. Vienna, and C.-W. Chung. 2012c. Glass Ceramic Formulation Data Package, PNNL-21471, Pacific Northwest National Laboratory, Richland, WA.

Crum, J.V. and D.M. Strachan. 2013. Epsilon Metal Summary Report Fiscal Year 2013, FCRD-SWF2013-000292, Pacific Northwest National Laboratory, Richland, WA.

Crum, J.V., D.M. Strachan, A. Rohatgi, and M.R. Zumhoff. 2013. "Epsilon Metal Waste Form for Immobilization of Noble Metals from Used Nuclear Fuel," Journal of Nuclear Materials, 441:103-112.

Crum, J.V., V. Maio, J.S. Mccloy, C. Scott, B.J. Riley, B. Benefiel, J.D. Vienna, K. Archibald, C. Rodriguez, V. Rutledge, Z.H. Zhu, J.V. Ryan, and M.J. Olszta. 2014. "Cold Crucible Induction Melter Studies for Making Glass Ceramic Waste Forms: A Feasibility Assessment," Journal of Nuclear Materials, 444:481-492.

Cui, D., J. Low, C.J. Sjostedt, and K. Spahiu. 2004. "On Mo-Ru-Tc-Pd-Rh-Te Alloy Particles Extracted from Spent Fuel and Their Leaching Behavior under Ar and H-2 Atmospheres," Radiochimica Acta, 92(9-11):551-555.

Cunnane, J.C. 2009. Initial Conceptual Model and Planned Testing Approach - Metal Waste Form, FCRD-WAST-2010-000014, Argonne National Laboratory, Argonne, IL.

Cunnane, J.C. 2010. Conceptual Model and Results of Corrosion Experiments, FCRD-WAST-2010000162, Argonne National Laboratory, Argonne, IL.

CWI. 2009. Calcine Disposition Project Calcine Treatment Options Summary, RPT-650, Rev 0, Idaho Cleanup Project, Idaho Falls, ID. 
CWI. 2011a. Calcine Disposition Project Technology Maturation Plan, PLN-1482, Rev 2, Idaho Cleanup Project, Idaho Falls, ID.

CWI. 2011b. Contractor Project Execution Plan for the Calcine Disposition Project, PLN-2431, Rev 4, Idaho Cleanup Project, Idaho Falls, ID.

Dalba, G., P. Fornasini, and F. Rocca. 1990. "Short Range Order in AgI:Ag $\mathrm{O}_{2}: \mathrm{B}_{2} \mathrm{O}_{3}$ Glasses: Results from EXAFS and Related Techniques," Journal of Non-Crystalline Solids, 123(1-3):310-314.

Davis, J.S. and J.R. Martin. 1973. "A Cryogenic Approach to Fuel Reprocessing Gaseous Radioactive Waste Treatment.” In Proceedings of the Symposium on Noble Gases, pp 302-313, Las Vegas, NV.

Day, D.E. and C.S. Ray. 2013. A Review of Iron Phosphate Glasses and Recommendations for Vitrifying Hanford Waste, Missouri University of Science and Technology, Rolla, MO.

Dayal, R. and E.J. Reardon. 1992. "Cement-Based Engineered Barriers for Carbon-14 Isolation," Waste Manage, 12(2-3):189-200. 10.1016/0956-053X(92)90048-N.

Debasi, B. et. al., Potential of Metal Organic Frameworks for Separation of Xenon and Krypton. Accounts of Chemical Research, DOI: 10.1021/ar5003126

Demine, A.V., N.V. Krylova, P.P. Polyektov, I.N. Shestoperov, T.V. Smelova, V.F. Gorn, and G.M. Medvedev. 2001. "High Level Liquid Waste Solidification Using a 'Cold' Crucible Induction Melter," Scientific Basis for Nuclear Waste Management XXIV, Vol. 663, 27-33 pp. Materials Research Society, Warrendale, PA.

DOE. 1979. Technology for Commercial Radioactive Waste Management, US Department of Energy, Washington, DC.

DOE. 2009. Amended Record of Decision: Idaho High-Level Waste and Facilities Disposition Final Environmental Impact Statement Revised by State 12/21/09, Federal Register Doc. E9-31151, U.S. Department of Energy, Washington, D.C.

Dubberly, A.E., K. Yoshida, C.E. Boardman, and T. Wu. 2000 "Superprism Oxide and Metal Fuel Core Designs," in Proceedings of the 8th International Conference on Nuclear Engineering, ICONE 8, American Society of Mechanical Engineers, Baltimore, MD.

Durham, R.W. 1957. "Fission Product Disposal in Glass." in Proceedings of Fixation of Radioactivity in Stable, Solid Media, AEC TID-7550, pp. 8-9, U.S. Atomic Energy Commission, Washington, D.C.

Ebert, W.L. 2005. Testing to Evaluate the Suitability of Waste Forms Developed for Electrometallurgically-Treated Spent Sodium-Bonded Nuclear Fuel for Disposal in the Yucca Mountain Repository, ANL-05/43, Argonne National Laboratory, Argonne, IL.

Ebert, W.L. 2008. Immobilizing Gnep Wastes in Pyrochemical Process Waste Forms, GNEP-WASTPMO-MI-DV-2008-000150, Argonne National Laboratory, Argonne, IL.

Ebert, W. 2010. Formulating a Glass-Bonded Mineral Waste Form for Waste Salts with High Cs and Sr Contents, AFCI-WAST-2010-000173, Argonne National Laboratory, Argonne, IL. 
Ebert, W.L. 2014. Radionuclide Source Term Model for Metallic Waste Forms. FCRD-SWF-2014000224, Argonne National Laboratory, Argonne, IL.

Ebert, W.L. 2012. Development of a Corrosion Model for Metal Waste Forms: FY2012 Status Report, FCRD-SWF-2012-000158, Argonne National Laboratory, Argonne, IL.

Ebert, W.L., D.W. Esh, S.M. Frank, K.M. Goff, M.C. Hash, S.G. Johnson, M.A. Lewis, L.R. Morss, T.L. Moschetti, T.P. O'holleran, M.K. Richmann, J. Riley, W. P., L.J. Simpson, W. Sinkler, M.L. Stanley, C.D. Tatko, D.J. Wronkiewicz, J.P. Ackerman, K.A. Arbesman, K.J. Bateman, T.J. Battisti, D.G. Cummings, T. Disanto, M.L. Gougar, K.L. Hirsche, S.E. Kaps, L. Leibowitz, J.S. Luo, M. Noy, H. Retzer, M.F. Simpson, D. Sun, A.R. Warren, and V.N. Zyryanov. 1999. Ceramic Waste Form Handbook, ANL-NT-119, Argonne National Laboratory, Argonne, IL.

Ebert, W., N. Deitz, and D. Janney. 2005. Effects of Heat-Treatment and Formulation on the Phase Composition and Chemical Durability of the EBR-II Ceramic Waste Form, ANL-05/32, Argonne National Laboratory, Argonne, IL.

Ebert, W., M. Williamson, and S. Frank. 2009a. Immobilizing Tc-Bearing Waste Streams in an IronBased Alloy Waste Form, AFCI-WAST-PMO-MI-DV-2009-000160, Argonne National Laboratory, Argonne, IL.

Ebert, W., J. Fortner, I. Shkrob, and G. Jarvinen. 2009b. Options for Recovering and Immobiliziong the Tc Dissolved During Oxide Fuel Dissolution, AFCI-WAST-PMO-MI-DV-2009-000161, Argonne National Laboratory, Argonne, IL.

Ebert, W., S. Frank, L. Olson, E. Buck, and D. Zagidulin. 2011. Reference Alloy Waste Form RAW-1, FCRD-WAST-2011-000185, Argonne National Laboratory, Argonne, IL.

Ebert, W.L., T.A. Cruse, and J.A. Fortner. 2012. Electrochemical Measurements with RAW-1(Tc), FCRDSWF-2012-000200, Argonne National Laboratory, Argonne, IL.

Ebert, W.L. and D. Kolman. 2013. Alloy Waste Form Testing Strategy Roadmap, FCRD-SWF-2013000226, Argonne National Laboratory, Argonne, IL.

Ebert, W.L. and Cruse, T.A. 2014. Unpublished data. Argonne National Laboratory.

Eichholz, G.G. 1988. Tritium Penetration through Concrete, Project E25-626, Georgia Institute of Technology, Atlanta, GA.

EM-TEG. 2011. EM-TEG Report on the Idaho Calcine Disposition Project, Environmental Management Technical Expert Group, U. S. Department of Energy, Office of Environmental Management, Washington, D.C.

EPA. 2010a. Chapter 40. Environmental Protection Agency: Part 61--National Emission Standards for Hazardous Air Pollutants. Subpart H-National Emission Standards for Emissions of Radionuclides Other Than Radon from Department of Energy Facilities. 92 - Standard, 40CFR61.92. US Environmental Protection Agency, Washington, DC.

EPA. 2010b. Protection of Environment: Chapter I--Environmental Protection Agency: Part 190-Environmental Radiation Protection Standards for Nuclear Power Operations, 40CFR190.10. US Environmental Protection Agency, Washington, DC. 
Fernandez, C. A., J. Liu, P.K. Thallapally, and D.M. Strachan. 2012. "Switching Kr/Xe Selectivity with Temperature in a Metal Organic Framework,” J. Am. Chem. Soc., 134:9046-9049.

Fortner, J. 2007. Characterization of Undissolved Solids from Fuel Dissolution for UREX+ Demonstration. Argonne National Laboratory, Argonne, IL

Fortner, J.A. and W.L. Ebert. 2012. Status of Static Corrosion Tests with RAW-1(Tc), FCRD-UFD-2012000202, Argonne National Laboratory, Argonne, IL.

Frank, S.M. 2011. Development and Characterization of New High-Level Waste Forms for Achieving Waste Minimization from Pyroprocessing, I-NERI-2007-004-K, INL/EXT-11-23352, Idaho National Laboratory, Idaho Falls, ID.

Frank, S. to T.P. O'Holleran. 2004. "Product Consistency Test and Density Measurement Results from Surrogate CWF Inter-Granular Glass Material” ANL-W Memo ENT-MS-(SMF)-04-005, August 26, 2004, Argonne National Laboratory, Idaho Falls, ID.

Frank, S.M., W.L. Ebert, and L. Olson. 2012. Final Report on Test Alloy Fabrication and Oxide Addition Studies, FCRD-SWF-2012-000234, Idaho National Laboratory, Idaho Falls, ID.

Fredrickson, G. 2014. "Estimation of Composition of Salt Waste from Near-Term Pyroprocessing Flowsheet," Idaho National Laboratory Interoffice Memo to T.A. Todd, dtd. August 4, 2014, Idaho National Laboratory, Idaho Falls, ID.

Fujihara, H., T. Murae, R. Wada, and T. Nishimura. 1999. "Fixation of radioactive iodine by hot isostatic pressing," 7th International Conference on Radioactive Waste Management and Environmental Remediation, ICEM '99, 1-5 pp. Nagoya, Japan.

Furrer, J., K. Jannakos, A. Linek, J.G. Wilhelm, and H. Braun. 1984 Dissolver-Offgas Cleaning in A Reprocessing Plant: Problems and Solutions. In Proceedings of Proceedings of International Topical Meeting, Fuel Reprocessing and Waste Management., The American Nuclear Society, LaGrande Park, IL.

Furrer, J., J.G. Wilhelm, and K. Jannukos. 1979 Aerosol and Iodine Removal System for the Dissolver Off-Gas in a Large Fuel Reprocessing Plant. In Proceedings of the $15^{\text {th }}$ DOE/NRC Nuclear Air Cleaning Conference, Harvard Air Cleaning Laboratory, Boston, MA.

Gahlert, S. and G. Ondracek. 1988a. "Powder Technology Vitrification of Highly Radioactive-Waste from Light-Water-Reactor (Lwr) and Fast-Breeder Reactor Reprocessing," Collection of Papers from the 7th Status Report of the Waste Treatment and Reprocessing Project: pp 453-463.

Gahlert, S. and G. Ondracek. 1988b. "Sintered Glass." In Radioactive Waste Forms for the Future, eds. W. Lutze and R.C. Ewing, pp. 161-192. North-Holland, Amsterdam.

Garino, T.J., T.M. Nenoff, J.L. Krumhansl, and D.X. Rademacher. 2011. "Low-Temperature Sintering Bi-Si-Zn-Oxide Glasses for Use in Either Glass Composite Materials or Core/Shell ${ }^{129}$ I Waste Forms," Journal of the American Ceramic Society, 94(8):2412-2419. 
Garn, T. G., M. Mitchell, R. Greenhalgh, and J. D. Law. 2012. FY-12 INL Krypton Capture Activities Supporting the Off-Gas Sigma Team, FCR\&D-SWF-2012-000252, Idaho National Laboratory, Idaho Falls, ID.

Garn, T.G. and M.R. Greenhalgh. 2013. Pressure Swing and Thermal Swing Adsorption Capacity Comparisons for $\mathrm{Kr}$ and Xe Using AgZ-PAN and HZ-PAN Sorbents, FCRD-SWF-2013-000273, Idaho National Laboratory, Idaho Falls, ID.

Garn, T.G., J.D. Law, M. Greenhalgh, and T.J. Tranter. 2014. "A Composite Media for Fluid Stream Processing, a Method of Forming the Composite Media, and a Related Method of Processing a Fluid Stream," United States Patent No. 8,686,083.

Gastellum, J.A., B.E. Ford, and J.T. Carter. 2012. Reprocessing Waste Spreadsheet Model Documentation, FCRD-UFD-2012-000138, PNNL-21621, Pacific Northwest National Laboratory, Richland, WA.

Gauthier-Lafaye, F., P. Holliger, and P.L. Blanc. 1996. "Natural Fission Reactors in the Franceville Basin, Gabon: A Review of the Conditions and Results of a 'Critical Event' in a Geologic System," Geochimica et Cosmochimica Acta, 60(23):4831-4852.

Geens, L., G. Collard, W.R.A. Goossens, and P.J. Vaesen. 1981. Experience Gained in the Cryodistillation Unit for Krypton Removal, BLG-547, Belgionucleaire, Mol, Belgium

Geens, L.P., G.E.R. Collard, W.R.A. Goossens, and L.H. Baetsle. 1985. "Krypton Recovery from Reprocessing Off-Gases by Cryogenic Distillation," Radioact. Waste Manage. Nucl. Fuel Cycle, 6(34):219-235.

Geens, L.P., W.R.A. Goossens, and J. Marien. 1986. Capture of Kyrpton by Cryogenic Distillation, EUR10515, S.C.K./C.E.N., Mol, Belgium

Geniesse, D. J., and G. E. Stegen. 2009. 2009 Evaluation of Tritium Removal and Mitigation Technologies for Wastewater Treatment, DOE/RL-2009-18, Areva Federal Services, Richland, WA.

Gesser, C., G. Hedin, H. Johansson, B. Torstenfelt, and T. Waltersten. 2000. "Versatile Cement Solidification of Low- and Intermediate Level Radwaste with the Moss System," Waste Management 2000, Tucson, AZ.

Gin, S. and J.P. Mestre. 2001. "Son 68 Nuclear Glass Alteration Kinetics between pH 7 and pH 11.5," Journal of Nuclear Materials, 295(1):83-96.

Ginell, W.S., J.J. Martin, and L.P. Hatch. 1954. "Ultimate Disposal of Radioactive Wastes," Nucleonics, 12(12):14-18.

Goldman, M.I., J.A. Servizi, R.A. Lauderdale, and R. Eliassen. 1957. "Fixation of Fission Products in Ceramic Glazes." In Proceedings of Fixation of Radioactivity in Stable, Solid Media, CONF-15, pp. 388, US Atomic Energy Commission, Washington, D.C.

Goles, R.W. and A.J. Schmidt. 1992. "Evaluation of Liquid-Fed Ceramic Melter Off-Gas System Technologies for the Hanford Waste Vitrification Plant," PNL-8109, Pacific Northwest Laboratory, Richland, WA. 
Goles, R.W., J.A. Del Debbio, R.J. Kirkham, B.D. Macisaac, J.A. McCray, D.D. Siemer, and N.R. Soelberg. 2002. Test Summary Report INEEL Sodium-Bearing Waste Vitrification Demonstration RSM01-2, PNNL-13869, Pacific Northwest National Laboratory, Richland, WA.

Goles, R.W., J.M. Perez, B.D. Macisaac, D.D. Siemer, and J.A. Mccray. 2001. Test Summary Report INEEL Sodium-Bearing Waste Vitrification Demonstration RSM-01-1, PNNL-13522, Pacific Northwest National Laboratory, Richland, WA.

Gombert, D., R. Counce, A. Cozzi, J.V. Crum, W.L. Ebert, C.M. Jantzen, J. Jerden, R. Jubin, M.D. Kaminski, V. Maio, J.C. Marra, T.M. Nenoff, R.D. Scheele, H.D. Smith, B. Spencer, D.M. Strachan, and J.D. Vienna. 2007. Global Nuclear Energy Partnership Integrated Waste Management Strategy Waste Treatment Baseline Study, GNEP-WAST-AI-RT-2007-000324, Idaho National Laboratory, Idaho Falls, ID.

Gombert, D., J. Carter, A. Cozzi, R. Jones, G. Matthern, M. Nutt, S. Priebe, and K.B. Sorenson. 2008. Global Nuclear Energy Partnership Integrated Waste Management Strategy, GNEP-WAST-WAST-AIRT-2008-000214, Idaho National Laboratory, Idaho Falls, ID.

Gong, W.L., W. Lutze, and R.C. Ewing. 2000. "Zirconia Ceramics for Excess Weapons Plutonium Waste," Journal of Nuclear Materials, 277(2-3):239-249. http://dx.doi.org/10.1016/S00223115(99)00195-6.

Goode, J.H. and R.G. Stacy. 1978. Head-End Reprocessing Studies with H. B. Robinson-2 Fuel, ORNL/TM-6037, Oak Ridge National Laboratory, Oak Ridge, TN.

Goode, J.H., R.G. Stacy, and V.C.A. Vaughen. 1980. Comparison Studies of Head-End Processing Using Three LWR Fuels, ORNL/TM-7103, Oak Ridge National Laboratory, Oak Ridge, TN.

Goossens, W.R.A., G.G. Eichholz, and D.W. Tedder. 1991. "Treatment of Gaseous Effluents at Nuclear Facilities," in Radioactive Waste Management Handbook 2, Harwood Academic Publishers, Chur.

Goumondy, J.P., P. Miquel, and E. Zellner. 1981. Removal Processes of Iodine in Reprocessing Plants, Commissariat à l'énergie atomique et aux énergies alternatives, Bagnols-sur-Cèze, France.

Gray, P. L. 1981. The National Long-Term High-Level Waste Technology Program, presented at the Winter Meeting of the American Nuclear Society, DP-MS-81-57, E. I. du Pont de Nemours \& Co. Savannah River Laboratory, Aiken, SC.

Groenier, W.S. and B.A. Hannaford. 1975. Engineering Evaluation of the Iodox Process. 2. Removal of Iodine from Air Using a Nitric Acid Scrub in a Bubble-Cap Column. 3. Correlation of Mass-Transfer Data. 4. Process Sensitivity to Impurities, ORNL-TM-4701, Oak Ridge National Laboratory, Oak Ridge, TN.

Guo, H., H. Tao, Y. Zhai, S. Mao, and X. Zhao. 2007a. "Raman spectroscopic analysis of $\mathrm{GeS}_{2}-\mathrm{Ga}_{2} \mathrm{~S}_{3}-$ $\mathrm{PbI}_{2}$ chalcohalide glasses," Spectrochimica Acta Part A: Molecular and Biomolecular Spectroscopy, 67(5):1351-1356. DOI: 10.1016/j.saa.2006.10.023.

Guo, H., Y. Zhai, H. Tao, Y. Gong, and X. Zhao. 2007b. "Synthesis and properties of $\mathrm{GeS}_{2}-\mathrm{Ga}_{2} \mathrm{~S}_{3}-\mathrm{PbI}_{2}$ chalcohalide glasses," Materials Research Bulletin, 42(6):1111-1118. DOI: 10.1016/j.materresbull.2006.09.007. 
Gutknecht, T.Y. 2012. "Thermal Analysis of Surrogate Simulated Molten Salts with Metal Chloride Impurities for Electrorefining Used Nuclear Fuel," Masters of Science, University of Idaho, Moscow, ID.

Han, Y.D. 2013. Operating Experience and Effect of the Wolsung Tritium Removal Facility: LAEA Workshop in Buenos Aires, Argentina, November 2013, International Atomic Energy Agency, Vienna, Austria.

Haruguchi, Y., S. Higuchi, M. Obata, T. Sakuragi, R. Takahashi, and H. Owada. 2013. "A study on Iodine Release Behavior from Iodine-Immobilizing Cement Solid," Scientific Basis for Nuclear Waste Management XXXVI, Vol. Materials Research Society Symposium Proceedings Vol. 1518, 85-90 pp. Materials Research Society, Cambridge, England.

Hatch, L.P. 1953. "Ultimate Disposal of Radioactive Wastes," American Scientist, 41:410-421.

Hebel, W., and G. Cottone, eds. 1982. Management Modes for Iodine-129, Harwood Academic Publishers. Switzerland.

Hebel, W., and G. Cottone, eds. 1983. Methods of Krypton-85 Managment, Harwood Academic Publishers. Switzerland.

Hench, L.L., R.J.Charles, A.R.Cooper, R.C.Ewing, J.R.Hutchins, D.W.Readey, F.L. Versnyder, and S.M.Widerhorn. 1979. The Evaluation and Selection of Candidate High Level Waste Forms. Alternative Waste Form Peer Review Panel Report No. 1, US Department of Energy, Washington, DC.

Hench, L.L., R.J.Charles, A.R.Cooper, R.C.Ewing, J.R.Hutchins, D.W.Readey, F.L. Versnyder, and S.M.Widerhorn. 1980a. The Evaluation and Selection of Candidate High Level Waste Forms. Alternative Waste Form Peer Review Panel Report No. 2, US Department of Energy, Washington, DC.

Hench, L.L., R.J.Charles, A.R.Cooper, R.C.Ewing, J.R.Hutchins, D.W.Readey, F.L. Versnyder, and S.M.Widerhorn. 1980b. The Evaluation and Selection of Candidate High Level Waste Forms. Alternative Waste Form Peer Review Panel Report No. 3, US Department of Energy, Washington, DC.

Henrich, E. 1985. "Selective Absorption of Noble Gases in Freon-12 at Low Temperatures and Atmospheric Pressure," the $18^{\text {th }}$ DOE Nuclear Air Cleaning Conference (CONF-840806), US Department of Energy, Washington, DC.

Henrich, E. and R. Von Ammon. 1985a. "Concept of Off-Gas Purification in Reprocessing Plants," Atomkernenerg./Kerntech., 46(2):81-88.

Henrich, E. and R. von Ammon. 1985b. "Das Konzept Der Abgasreingung in Wiederaufarbeitungsanlgen," Atomkernenergie, Kerntechnik, 46(2):81-88.

Herrmann, B., V. Motoi, H. Fies, B. Stojanik, J. Furrer, and R. Kaempffer. 1988. "Testing an Iodine Filter for the Vessel Offgas of the German Industrial-Scale Reprocessing Plant," the $20^{\text {th }}$ DOE/NRC Nuclear Air Cleaning Conference, Vol. 1, 234-245 pp. The Harvard Air Cleaning Laboratory, Cambridge, MA.

Herrmann, F.J., V. Motoi, B. Herrmann, A.V. Schoor, D.Fang, and B. Fies. 1990. "Retention and Measurement of Iodine-129 and Organiciodine in the Offgas Streams of the Karlsruhe Reprocessing Plant WAK." In Proceedings of $21^{\text {st }}$ DOE/NRC Nuclear Air Cleaning Conference, Harvard Air Cleaning Laboratory, Boston, MA. 
Herrmann, F.J., V. Motoi, B. Herrmann, D. Fang, L. Finsterwalder, K.D. Kuhn, A. Van Shoor, C. Beyer, J. Furrer, and W. Knoch. 1993. "Minimizing of Iodine-129 Release at the Karlsruhe Reprocessing Plant WAK (CONF-902083)." In Proceedings of the $22^{\text {nd }}$ DOE/NRC Nuclear Air Cleaning and Treatment Conference, The Harvard Air Cleaning Laboratory, Cambridge, MA.

Herrmann, F.J., B. Herrmann, K.D. Kuhn, A. Van Schoor, M. Weishaupt, J. Furrer, and W. Knoch. 1997. "Control of Radio-Iodine at the German Reprocessing Plant WAK During Operation and after Shutdown," the $24^{\text {th }}$ DOE/NRC Nuclear Air Cleaning and Treatment Conference (NUREG/CP-0153, CONF-960715), 618-627 pp. The Harvard Air Cleaning Laboratory, Cambridge, MA.

Holladay, D. W. 1978. Experiments with a Lime Slurry in a Stirred Tank for the Fixation of Carbon-14 Contaminated $\mathrm{CO}_{2}$ from Simulated HTGR Fuel Reprocessing Off-Gas, ORNL/TM-5757, Oak Ridge National Laboratory, Oak Ridge, TN.

Holladay, D.W. 1979. A Literature Survey: Methods for the Removal of Iodine Species from Off-Gases and Liquid Waste Streams of Nuclear Power and Nuclear Fuel Reprocessing Plants, with Emphasis on Solid Sorbents, ORNL/TM-6350, Oak Ridge National Laboratory, Oak Ridge, TN.

Holtslander, W.J., T.E. Harrison, and D.A. Spagnolo. 1990. "The Chalk River Tritium Extraction Plant," Fusion Engineering and Design, 12(3):357-363. http://dx.doi.org/10.1016/0920-3796(90)90008-T.

Horen, A.S. and M.W. Lee. 1992. "Metal Hydride Based Isotope Separation - Large-Scale Operations," Fourth National Topical Meeting on Tritium Technology in Fission, Fusion, and Isotopic Applications, Vol. 21, 282-286 pp. Albuquerque, NM.

Hrma, P.R. 2010. Retention of Halogens in Waste Glass, PNNL-19361, Pacific Northwest National Laboratory, Richland, WA.

Hudson, P. I., C. P. Buckley, and W. W. Miller. 1995. "The Development and Design of the Off-Gas Treatment System for the Thermal Oxide Reprocessing Plant (THORP) at Sellafield," in Proceedings of the 23rd DOE/NRC Nuclear Air Cleaning and Treatment Conference, p. 333-351.

Hutter, E., J. Amend, R. Von Ammon, W. Bumiller, and G. Neffe. 1987. Final Results and Consequences of the Development of a Cryogenic Krypton Separation System, 0270-6482, Kernforschungszent. Karlsruhe G.m.b.H.

IAEA. 1980. Separation, Storage and Disposal of Krypton-85, TRS-199, International Atomic Energy Agency, Vienna, Austria.

IAEA. 1987. Treatment, Conditioning and Disposal of Iodine-129, TRS-276, International Atomic Energy Agency, Vienna, Austria.

IAEA. 2013. The Behaviours of Cementitious Materials in Long Term Storage and Disposal of Radioactive Waste - Results of a Coordinated Research Project, TECDOC-1701, International Atomic Energy Agency, Vienna, Austria.

IAEA. 2014. Treatment of Radioactive Gaseous Waste, TECDOC-1744, International Atomic Energy Agency, Vienna, Austria. 
Inada, E., N. Miura, O. Kuriyama, H. Tobita, S. Motoyama, and N. Tsunoda. 1979. Fundamental Research on Pretreatment Process for Krypton-85 Recovery System. (IV). Adsorption Experiments of Krypton, Xenon and Carbon Dioxide on Some Adsorbents at Low Temperatures.

Isomura, S., K. Suzuki, and M. Shibuya. 1988. "Separation and Recovery of Tritium by Hydrogen-Water Isotopic Exchange Reaction," Fusion Technol., 14(2, Pt. 2A):518-523.

JAEA and FEPC. 2007. Second Progress Report on Research and Development for TRU Waste Disposal in Japan, JAEA-Review 2007-010, FEPC TRU-TR2-2007-01, Japan Atomic Energy Agency and The Federation of Electric Power Companies of Japan, Tokai-mura, Japan.

Jantzen, C.M. 1988. Glass Compositions and Frit Formulations Developed for DWPF, DPST-88-952, Savannah River Laboratory, Aiken, SC.

Jeppson, D.W., R.K. Biyani, and J.B. Duncan. 1997. 1997 Evaluation of Technologies for Removal and Mitigation of Tritium for Hanford Site Waste Waters, DOE/RL-97-54, Rev. 0, COGEMA Engineering Corporation for U. S. Department of Energy, Richland Operations Office, Richland, WA.

Jeon, M.K., J.M. Shin, J.J. Park, and G. Il Park. 2012. "Simulation of Cs Behavior During the High Temperature Voloxidation Process Using the HSC Chemistry Code," Journal of Nuclear Materials, 430(1-3):37-43. DOI 10.1016/j.jnucmat.2012.06.040.

Johnson, J.A., G.D. Delcul, B.B. Spencer, E.D. Collins, and R.D. Hunt. 2013. Kinetics of $\mathrm{NO}_{2}$ Reactions with Uranium Oxides, FCRD-SWF-2013-000164, Oak Ridge National Laboratory, Oak Ridge, TN.

Jones, R.H. 2011a. Low Level Waste Disposition - Quantity and Inventory, FCRD-USED-2010-000033, Rev. 2, Savannah River National Laboratory, Aiken, SC.

Jones, R.H. 2011b. Low Level Waste Inventory from MOX Fuel Fabrication, FCRD-USED-2011-000059, Savannah River National Laboratory, Aiken, SC.

Jones, R.H. 2012. Low Level Waste Disposition - LLW Treatment/Management Data Input, FCRD-UFD2012-000185, Rev. 1, Savannah River National Laboratory, Aiken, SC.

Jones, R.H, 2013, Low Level Radioactive Waste Disposition - LLW Treatment/Management Data Input, FCRD-UFD-2013-000195, Rev. 1, Savannah River National Laboratory, Aiken, SC.

Jones, R.H. and J.T. Carter. 2013. Comparison of Waste Estimates from Recycling and Fuel Fabrication, FCRD-UFD-2013-000178, Savannah River National Laboratory, Aiken, SC.

Jubin, R.T. 1979. A Literature Survey of Methods to Remove Iodine from Off-Gas Streams Using Solid Sorbents, ORNL/TM-6607, Oak Ridge National Laboratory, Oak Ridge, TN.

Jubin, R.T. 1983. "Organic Iodine Removal from Simulated Dissolver Off-Gas Streams Using Partially Exchanged Silver Mordenite," 17th Annual Department of Energy Nuclear Air Cleaning Conference, Vol. 1, 183-198 pp. U.S. Department of Energy, Denver, CO.

Jubin, R.T. 2012. Summary of FY 2012 Off-Gas Sigma Team Activities, FCRD-SWF-2012-000331, Oak Ridge National Laboratory, Oak Ridge, TN. 
Jubin, R.T., G.D. Delcul, J.M. Giaquinto, E.S. Meyers, D.W. Ramey, R.S. Owens, and B.B. Spencer. 2009. "AFCI Fuel Reprocessing R\&D: Performance of Coupled End-to-End Integrated Voloxidation and Dissolver Off-Gas Treatment " Global 2009, Paper 9264. American Nuclear Society.

Jubin, R.T. and B.E. Lewis. 1987. Demonstration of the Iodine and Nitrogen Oxide (NOx) Removal Systems in the Oak Ridge National Laboratory (ORNL) Integrated Equipment Test (Iet) Facility, 02706482, Oak Ridge National Laboratory, Oak Ridge, TN.

Jubin, R.T., D.W. Ramey, R.S. Owens, E.S. Meyers, B.B. Spencer, P.D. Bailey, and J.M. Giaquinto. 2010. "Control of Volatile Radionuclides from the Dissolution of Used Nuclear Fuel - 10224," Waste Management 2010, Paper no. 10224 pp. Phoenix, AZ.

Jubin, R.T., N.R. Soelberg, D.M. Strachan, and G. Ilas. 2012a. Position Paper on Practicable Performance Criteria for the Removal Efficiency of Volatile Radionuclides, FCRD-SWF-2012-000091, Oak Ridge National Laboratory, Oak Ridge, TN.

Jubin, R.T., N.R. Soelberg, D.M. Strachan, and G. Ilas. 2012b. Fuel Age Impacts on Gasous Fission Product Capture During Separations, FCRD-SWF-2012-000091, Oak Ridge National Laboratory, Oak Ridge, TN.

Jubin, R. T., D. W. Ramey, B. B. Spencer, K. K. Anderson, and S. M. Robinson. 2012c. "Impact of Pretreatment and Aging on the Iodine Capture Performance of Silver-Exchanged Mordenite," In Proceedings of Waste Management 2012, Paper \# 12314, Phoenix, AZ.

Jubin, R.T., D.M. Strachan, and N.R. Soelberg. 2013. Iodine Pathways and Off-Gas Stream Characteristics for Aqueous Reprocessing Plants - A Literature Survey and Assessment, FCRD-SWF2013-000308, Oak Ridge National Laboratory, Oak Ridge, TN.

Jubin, R.T. and S.H. Bruffey. 2014. "High-Temperature Pressing of Silver-Exchanged Mordenite into a Potential Iodine Waste Form - 14096," Waste Management 2014, Paper number 14096, Phoenix, AZ

Jubin, R.T., D.M. Strachan, G. Ilas, B.B. Spencer, and N.R. Soelberg. 2014a. "Radioactive Semivolatiles in Nuclear Fuel Reprocessing," FCRD-SWF-2014-000601, Oak Ridge National Laboratory, Oak Ridge, TN.

Jubin, R.T., S.H. Bruffey, and K.K. Patton. 2014b. Expanded Analysis of Hot Isostatic Pressed IodineLoaded Silver-Exchanged Mordenite, FCRD-SWF-2014-000278, Oak Ridge National Laboratory, Oak Ridge, TN.

Kabat, M.J. 1979. "Monitoring and Removal of Gaseous Carbon-14 Species," Proceedings of the $15^{\text {th }}$ DOE Nuclear Air Cleaning Conference, Vol. 1, pp. 208-230. Cambridge, MA.

Kaneko, H., K. Miura, N. Yoshiki, H. Takeda, and T. Hoshino. 1978. Removal of Iodine Species by Concentrated Nitric Acid. (II). Fundamental Experiment by the Use of a Packed Column, PNCT-831-7802, pp. 84-90, Power Reactor and Nuclear Fuel Development Corp., Tokyo, Japan.

Kaneko, H., H. Muramoto, H. Takeda, T. Hoshino, and T. Segawa. 1980. "Iodine Removal in the PUREX Reprocessing Process," in Symposium on Fast Reactor Fuel Reprocessing, pp 185-194, Society of Chemical Industry, Dounreay, UK. 
Kaneko, H., N. Yoshiki, H. Takeda, and T. Hoshino. 1979. "Removal of Iodine Species with Concentrated Nitric Acid. (III). Fundamental Experiment of Iodine Concentration," In International Symposium on Fast Reactor Fuel Reprocessing, pp. 185. Dounreay, U.K.

Keilholtz, G.W. 1971. "Krypton-Xenon Removal Systems," Nucl. Safety, 12(6):591-599.

Keiser, D.D., D.P. Abraham, W. Sinkler, J.W. Richardson, and S.M. Mcdeavitt. 2000. "Actinide Distribution in a Stainless Steel-15 Mass\% Zirconium High-Level Nuclear Waste Form," J. Nucl. Mater., 279(2,3):234-244. 10.1016/S0022-3115(00)00002-7.

Kessler, G. 2012. Sustainable and Safe Nuclear Fission Energy, Technology and Safety of Fast and Thermal Nuclear Reactors. Springer, Heidelberg, Germany.

Khan, A.A., D.S. Deshingkar, and K. Ramarathinam. 1975. Krypton-85 Enrichment by AdsorptionDesorption Process, BARC-859, Bhabha Atomic Research Centre, Bombay, India

Klem, M.J. and G.E. Stegen. 2004. 2004 Evaluation of Tritium Removal and Mitigation Technologies for Wastewater Treatment, DOE/RL-2004-11, Rev. 0, COGEMA Engineering Corporation for U.S. Department of Energy, Richland Operations Office, Richland, WA.

Kleykamp, H. 1985. "The Chemical-State for the Fission-Products in Oxide Fuels," Journal of Nuclear Materials, 131(2-3):221-246.

Kleykamp, H. 1988. "The Chemical-State of the Fission-Products in Oxide Fuels at Different Stages of the Nuclear-Fuel Cycle," Nuclear Technology, 80(3):412-422.

Kleykamp, H. 1987. "Composition after Dissolution in $\mathrm{HNO}_{3}$ of the Residue of KNK-II-I Fuel," Atomwirtschaft-Atomtechnik, 32(5):235-236.

Kleykamp, H. and R. Pejsa. 1984. "X-Ray Diffraction Studies on Irradiated Nuclear-Fuels," Journal of Nuclear Materials, 124:56-63.

Kluk, A.F., H.C. Johnson, C.P. Mcginnis, M. Rinker, S.L. Ross, H.G. Sutter, and J. Vienna. 2011. Preliminary Technology Readiness Assessment of the Calcine Disposition Project, U. S. Department of Energy, Washington, D.C.

Koudelka, L. and M. Pisárcik. 1984. "Raman spectra and structure of As-S-I system glasses," Journal of Non-Crystalline Solids, 64(1-2):87-94.

Kouzes, R.T., K.E. Conlin, J.H. Ely, L.E. Erikson, W.J. Kernan, A.T. Lintereur, E.R. Siciliano, D.L. Stephens, D.C. Stromswold, R.M. Van Ginhoven, and M.L. Woodring. 2010. "Alternatives to ${ }^{3} \mathrm{He}$ for Neutron Detection for Homeland Security," Annu. Meet. Proc. Inst. Nucl. Mater. Manage.,

51st:kouze1/1-kouze1/9.

Kouzes, R.T., J.H. Ely, A.T. Lintereur, E.K. Mace, D.L. Stephens, and M.L. Woodring. 2011. "Neutron Detection Gamma Ray Sensitivity Criteria," Nucl. Instrum. Methods Phys. Res., Sect. A, 654(1):412-416. 10.1016/j.nima.2011.07.030.

Krumhansl, J.L., T.M. Nenoff, D. Haefner, and R.T. Jubin. 2009. "Novel Bismuth-Based Inorganic Oxide Waste Forms for Iodine Storage," Global 2009, Paper number 9282 pp. European Nuclear Society, Paris, France. 
Krumhansl, J.L. and T.M. Nenoff. 2011. "Hydrotalcite-like layered bismuth-iodine-oxides as waste forms," Applied Geochemistry, 26(1):57-64. DOI: 10.1016/j.apgeochem.2010.11.003.

Krumhansl, J.L. and T.M. Nenoff. 2013. "Mixed-Layered Bismuth-Oxygen-Iodine Materials for Capture and Waste Disposal of Radioactive Iodine," United States Patent No. US 8,383,021 B1.

Ladirat, C., J. Lacombe, R. Do Quang, and A. Prod'homme. 2004. "Advanced Cold Crucible Melter Pilot Plant Characteristics and First Results on Hllw Surrogates," Waste Management 2004, 4223 pp. Tucson, AZ.

Lambregts, M.J. and S.M. Frank. 2003. "Characterization of Cesium Containing Glass-Bonded Ceramic Waste Forms," Microporous and Mesoporous Materials, 64(1-3):1-9.

Langton, C.A. 1985. "Physical Properties of Saltstone: A Savannah River Plant Waste Form," Scientific Basis for Nuclear Waste Management VIII, Vol. 44, 859-864 pp. Materials Research Society, Pittsburg, PA.

Laser, M. 1976. Separation, Storage, and Disposal of Krypton-85: Status and Projects, KFA, Juelich.

Laser, M., H. Beaujean, J. Bohnenstingl, P. Filss, M. Heidendael, S. Mastera, E. Merz, and H. Vygen. 1973a. "Off-Gas Treatment and Krypton Disposal in HTGR-Fuel Element Reprocessing." In Proceedings of Symposium on the Management of Radioactive Wastes from Fuel Reprocessing, Organisation for Economic Co-operation and Development, Paris, France.

Laser, M., H. Beaujean, J. Bohnenstingl, P. Filss, M. Heidendael, S. Mastera, E. Merz, and H. Vygen. 1973b. "Off-Gas Treatment and Krypton Disposal in HTGR [High-Temperature Gas-Cooled Reactor] Fuel Element Reprocessing.” In Proceedings OECD Publ. Cent., Paris, France.

Lausch, J., R. Berg, L. Koch, M. Coquerelle, J.P. Glatz, C.T. Walker, and K. Mayer. 1994. "Dissolution Residues of Highly Burnt Nuclear Fuels," J. Nucl. Mater., 208(1-2):73-80. 10.1016/0022-3115(94)901996.

Lauzel, J. and F. Thurin. 2009. Summary of Art CCIM Phase II-A CCIM Sizing Studies, SGN9139000025, Societe Generale Pour Les Techniques Nouvelles (SGN), Paris, France.

Lepry, W.C., B.J. Riley, J.V. Crum, C.P. Rodriguez, and D.A. Pierce. 2013. "Solution-Based Approaches for Making High-Density Sodalite Waste Forms to Immobilize Spent Electrochemical Salts," Journal of Nuclear Materials, 442:350-359.

Leturcq, G., T. Advocat, K. Hart, G. Berger, J. Lacombe, and A. Bonnetier. 2001. "Solubility Study of Ti, Zr-Based Ceramics Designed to Immobilize Long-Lived Radionuclides," American Mineralogist, 86(78):871-880.

Lima, S.M., A.A. Andrade, T. Catunda, R. Lebullenger, F. Smektala, Y. Jestin, and M.L. Baesso. 2001. "Thermal and optical properties of chalcohalide glass," Journal of Non-Crystalline Solids, 284(1-3):203209. DOI: 10.1016/S0022-3093(01)00403-3.

Lin, C., G. Qu, Z. Li, S. Dai, H. Ma, T. Xu, Q. Nie, and X. Zhang. 2013. "Correlation Between Crystallization Behavior and Network Structure in GeS2-Ga2S3-CsI Chalcogenide Glasses," Journal of the American Ceramic Society, 96(6):1779-1782. DOI: 10.1111/jace.12394. 
Little, D.K. 1983. "Noble Gas Removal and Concentration by Combining Fluorocarbon Absorption and Adsorption Techniques," the $17^{\text {th }}$ DOE Nuclear Air Cleaning Conference (CONF-820833), US Department of Energy, Washington, DC.

Liu, J., Strachan, D. M., Thallapally, P. K., 2014. Enhanced noble gas adsorption in Ag@MOF-74Ni, Chemical Communications, 50, 466-468.

Liu, J., Fernandez, C. A., Martin P. F., Strachan, D. M., Thallapally, P. K., 2014. A Two-Column Method for the Separation of $\mathrm{Kr}$ and Xe from Process Off-Gases. Industrial \& Engineering Chemistry Research, $53,12893-12899$.

Liu, J., Strachan, D. M., Thallapally, P. K., 2012. Metal Organci Frameworks for Removal of Xe and Kr from Nuclear Reprocessing Plants. Langmuir, 28, 11584-11589.

Lopez-Gutierrez, J.M., M. Garcia-Leon, C. Schnabel, M. Suter, H.A. Synal, S. Szidat, and R. GarciaTenorio. 2004. "Relative influence of 129I sources in a sediment core from the Kattegat area," Science of the Total Environment, 323 195-210.

Lumpkin, G.R., K.L. Smith, and M.G. Blackford. 1995. "Development of Secondary Phases on Synroc Leached at $150^{\circ} \mathrm{C}$.," Materials Research Society Symposium Proceedings, 353:855-862.

Lutze, W. and R.C. Ewing. 1988. Radioactive Waste Forms for the Future. North-Holland Press, New York, New York.

Lutze, W., B. Grambow, and R.C. Ewing. 1990. "Performance of Borosilicate Glass, Synroc, and Spent Fuel as Nuclear Waste Forms," In Waste Management 1990, pp. 847-851, Tucson, AZ.

Maddrell, E.R. and P.K. Abraitis. 2004. "A comparison of wasteforms and processes for the immobilization of iodine-129," Mater. Res. Soc. Symp. Proc., 807(Scientific Basis for Nuclear Waste Management XXVII):261-266.

Maddrell, E., A. Gandy, and M. Stennett. 2014. "The Durability of Iodide Sodalite," J. Nucl. Mater., 449(1-3):168-172. 10.1016/j.jnucmat.2014.03.016.

Maeda, T., T. Banba, K. Sonoda, Y. Inagaki, and H. Furuya. 2001. "Release and Retention of Uranium During Glass Corrosion," Journal of Nuclear Materials, 298(1-2):163-167. DOI 10.1016/S00223115(01)00587-6.

Mailen, J.C. 1975. Use of Chemical Equilibrium Data to Calculate Iodox Column Operations, ORNL/TM-5077, Oak Ridge National Laboratory, Oak Ridge, TN.

Mailen, J.C. 1976. "Use of Chemical Equilibrium Data to Calculate Iodox Column Operations," Nucl. Technol., 30(3):325-332.

Maio, V. 2013. email, "Re: Melting Rate," to J.D. Vienna, INL, Idaho Falls, ID.

Maio, V. 2014. Glass-Ceramic High Level Waste Form Processability with Cold Crucible Induction Melter Technology, FCRD-SWF-2014-000256, Idaho National Laboratory, Idaho Falls, ID. 
Malagani, J. P., et al. 1978. "Conductive Electrique et Spectres de Diffusion Raman des Verres Mixtes Ag $\mathrm{PO}_{3} \mathrm{MI}_{2}$ Avec $\mathrm{M}=\mathrm{Co}, \mathrm{Hg}, \mathrm{Pb}$. Correlation Entre Conductivite et Structure," Mat. Res. Bull. 13, 317. Manowitz, B. and L.P. Hatch. 1954. "Processes for High-Level Waste Disposal," Nuclear Engineering, 50(12):144-152.

Malek, M., M.R. Khani, P. Alizadeh, and H. Kazemian. 2009. "Composite wasteform based on SiO2$\mathrm{PbO}-\mathrm{CaO}-\mathrm{ZrO} 2-\mathrm{TiO} 2-(\mathrm{B} 2 \mathrm{O} 3-\mathrm{K} 2 \mathrm{O})$ parent glass with zircon as the second component," Ceramics International, 35:1689-1692.

Marra, J.C. 2013. Review of DOE-EM Cold Crucible Induction Melter Testing Conducted from 20012012, SRNL-STI-2013-00696, Savannah River National Laboratory, Aiken, SC.

Martin, J.R. 1977. "Radioactive Krypton Gas Separation," Patent No. US4045191A.

Matlack KS, H Gan, W Gong, IL Pegg, CC Chapman, and I Joseph. 2007. High Level Waste Vitrification System Improvements. VSL-07R1010-1, Vitreous State Laboratory, The Catholic University of America, Washington, D.C. Also published as ORP-56297

Matlack KS, H Gan, M Chaudhuri, WK Kot, W Gong, T Bardakci, IL Pegg, and I Joseph. 2008. Melt Rate Enhancement for High Aluminum HLW Glass Formulations. VSL-08R1360-1, Vitreous State Laboratory, The Catholic University of America, Washington, D.C., Also published as ORP-44236

Matyáš, J., G.E. Fryxell, B.J. Busche, K. Wallace, and L.S. Fifield. 2011. "Functionalized Silica Aerogels: Advanced Materials to Capture and Immobilize Radioactive Iodine," Ceramic Materials for Energy Applications, 21-32 pp. American Ceramic Society, Westervill, OH.

Matyas, J., G.E. Fryxell, B.J. Busche, K. Wallace, and L.S. Fifield. 2012a. "Functionalized Silica Aerogels: Advanced Materials to Capture and Immobilize Radioactive Iodine," Ceramic Transactions, Vol. 236, American Ceramic Society, Westerville, OH.

Matyas, J., M.J. Robinson, and G.E. Fryxell. 2012b. "The Effect of Temperature and Uniaxial Pressure on the Densification Behavior of Silica Aerogel Granules," Ceramic Materials for Energy Applications II, Vol. 33, 121-125 pp. American Ceramic Society, Westerville, OH.

Matyas, J. and R.K. Engler. 2013. Assessment of Methods to Consolidate Iodine-Loaded SilverFunctionalized Silica Aerogel, PNNL-22874, Pacific Northwest National Laboratory, Richland, WA.

Maurel, J.M. and D. Vigla. 1987 "Behaviour of a Sorbent Material (AC 6120) for Iodine Removal in the Presence of Nitrogen Oxide." In Proceedings of the 19th DOE/NRC Nuclear Air Cleaning Conference (NUREG/CP-0086-VI)(Conf-860820), U.S. Nuclear Regulatory Commission, Washington, D.C.

Mausolf, E., F. Poineau, and K. Czerwinski. 2012. Synthesis, Corrosion, and Morphological Results of Cr-Doped Steel Alloys, FCRD-SWF-2012-000176, University of Nevada Las Vegas, Las Vegas, NV.

Mayzan, M.Z.H., M.C. Stennett, N.C. Hyatt, and R.J. Hand. 2014. "Graphite immobilisation in iron phosphate glass composite materials produced by microwave and conventional sintering routes," Journal of Nuclear Materials, 454:343-351.

McCloy, J.S., B.J. Riley, A.S. Lipton, C.F. Windisch, N.M. Washton, M.J. Olszta, and C.P. Rodriguez. 2013. "Structure and Chemistry in Halide Lead-Tellurite Glasses," Journal of Physical Chemistry C, 117(7):3456-3466. 
McDeavitt, S.M., D.P. Abraham, and J.Y. Park. 1998. "Evaluation of Stainless Steel-Zirconium Alloys as High-Level Nuclear Waste Forms," Journal of Nuclear Materials, 257:21-34.

Mendel, J. E., and J. L.McElroy. 1972. Waste Solidification Program, Volume 10, Evaluation of Solidied Waste Products, BNWL-1666, Battelle-Northwest, Richland, WA.

McElroy, J.L., K.J. Schneider, J. N. Hartley, J. E. Mendel, G. L. Richardson, R. W. McKee, and A. G. Blasewitz. 1972. Waste Solidification Program Summary Report, Volume 11, Evaluation of WESP High Level Waste Solidification Processes, BNWL-1667, Battelle Pacific Northwest Laboratories, Richland, WA.

Michie, E.M., R.W. Grimes, and A.R. Boccaccini. 2008. "Hot-pressed phosphate glass-ceramic matrix composites containing calcium phosphate particles for nuclear waste encapsulation," Journal of Material Science, 43:4152-4156.

Michling, R., I. Cristescu, L. Dorr, T. Fanghanel, S. Welte, and W. Wurster. 2008. "Behavior of Solid Polymer Membrane Electrolyzers in Use with Highly Tritiated Water," Fusion Science and Technology, 54(2):470-474.

Miller, A. I. and H. M. Van Alstyne. 1994. Heavy Water: A Distinctive and Essential Component of $C A N D U$, AECL-10962, Atomic Energy of Canada, Limited, Chalk River, Ontario.

Miller, A. I. 1999, Tritium Treatment Technologies for Groundwater Remediation at Savannah River Site, WSRC-OS-98-00127, prepared by Chalk River Laboratories and Atomic Energy of Canada, Limited, for Westinghouse Savannah River Company, Aiken, SC.

Miller, A. I., S. L. Celovsky, A. E. Everatt, W. R. C. Graham, and J. R. R. Tremblay. 2001. "Reply to Questions Regarding Tritium Removal Technologies," Letter to D. L. Penwell, March 7, 2001, Atomic Energy of Canada, Limited, Chalk River, Ontario.

Mineo H., M. Iizuka, S. Fujisaki. 2002. "Spent Fuel Dissolution Test Including Dissolver off-gas Treatment in the NUCEF Alpha-Gamma Cell: Spent Fuel with Burnup up to 44 GW/t" in Proceedings of NUCEF-2001, p. 511-518, JAERI, Tokai, Japan.

Miyakawa, H., T. Sakuragi, H. Owada, O. Kato, and K. Masuda. 2013. "Development of the Synthetic Rock Technique for the Immobilization of Iodine: Kinetics of the Alumina Matrix Dissolution under High Alkaline Conditions," Scientific Basis for Nuclear Waste Management XXXVI, Materials Research Society Symposium Proceedings Vol. 1518, 79-84 pp. Materials Research Society, Cambridge, England.

Modolo, G. and R. Odoj. 1997. "Investigations on the Partitioning of ${ }^{129}$ I from Silver-Impregnated Silica in Preparation for Future Transmutation," Nuclear Technology, 117(1):80-86.

Monson, P. R. 1981. "Krypton Retention on Solid Adsorbents," in Proceedings of the 16th DOE Nuclear Air Cleaning Conference, pg 1387-1400, San Diego, CA.

Monson, P.R. 1982. Krypton Retention on Solid Adsorbents, DP-1615, E. I. Du Pont de Nemours and Co., Aiken, SC. 
Moricca, S., C. Orcutt, M. W. A. Stewart, W. Bermudez, E. R. Vance, T. Eddowes, R. Persaud and D. Taylor. 2012. "Hot-isostatic Pressing of Synroc for nuclear waste disposal," in Proc. Powder Met. 2012, June 10-13, Nashville, TN.

Morrison, M.C. and K.J. Bateman. 2010. Perform 2nd Pre-Qualification Cwf Test Run, FCRD-SEPA2010-000057, Idaho National Laboratory, Idaho Falls, ID.

Morrison, M.C., K.J. Bateman, and M.F. Simpson. 2010. "Scale up of Ceramic Waste Forms for the EBR-II Spent Fuel Treatment Process," 3rd International Pyroprocess Research Conference, Research Institute of Atomic Reactors, Dimitrovgrad, Russia.

Morss, L.R. and W.L. Ebert. 2001. "Release of Uranium and Plutonium from the EBR-II Ceramic Waste Form." In Environmental Issues and Waste Management Technologies in the Ceramic and Environmental Issues and Waste Management Technologies in the Ceramic and Nuclear Industries VII, eds. G.L. Smith, S.K. Sundaram and D.R. Spearing, Vol 132. American Ceramic Society, Westerville, OH.

Mukunoki, A., T. Chiba, Y. Suzuki, S. Uehara, H. Asano, and T. Nishimura. 2007 Development of an iodine immobilization technique by low temperature vitrification with $\mathrm{BiPbO}_{2} \mathrm{I}$. In Proceedings of $11^{\text {th }}$ Int. Conf. Environ. Remed. Radioact. Waste Manag.

Mukunoki, A., T. Chiba, Y. Suzuki, K. Yamaguchi, T. Sakuragi, and T. Nanba. 2009 Further development of iodine immobilization technique by low temperature vitrification with $\mathrm{BiPbO}_{2} \mathrm{I}$. In Proceedings of $12^{\text {th }}$ Int. Conf. Environ. Remed. Radioact. Waste Manag.

Munakata, K. et al. 2003. "Adsorption of Noble gases on Silver-Mordenite," Journal of Nuclear Science and Technology, 40 (9):695-697.

Murphy, L.P., B.A. Staples, and T.R. Thomas. 1977. Development of $A g^{0}$ for Bulk ${ }^{129}$ I Removal from Nuclear Fuel Reprocessing Plants and $\mathrm{PbX}$ for ${ }^{129}$ I Storage, ICP-1135, Allied Chemical Company, Idaho Falls, ID.

Mustarelli, P., C. Tomasi, and A. Magistris. 2005. "Fractal Nanochannels as the Basis of the Ionic Transport in AgI-Based Glasses," Journal of Physical Chemistry B, 109(37):17417-17421. 10.1021/jp052305b.

NAS. 1995. An Assessment of Continued R\&D into an Electrometallurgical Approach for Treating DOE Spent Nuclear Fuel, National Academy of Science, Washington, D.C.

NAS. 2000. Electrometallurgical Techniques for DOE Spent Fuel Treatment, National Academy of Science, Washington, D.C.

Nakazawa, T., H. Kato, K. Okada, S. Ueta, and M. Mihara. 2001. "Iodine immobilization by sodalite waste form," Scientific Basis for Nuclear Waste Management XXIV, Vol. 663, 51-57 pp. Materials Research Society, Warrendale, PA.

Naline, S., F. Gouyaud, V. Robineau, C. Girold, and B. Carpentier. 2010. "Vitrification 2010 - A Challenging French Vitrification Project to Retrofit a Cold Crucible Inductive Melter at the Lahague Plant," Waste Management 2010, 10382 pp. Phoenix, AZ. 
NEA. 1980. Radiological Significance and Management of Tritium, Carbon-14, Krypton-85, and Iodine129 Arising from the Nuclear Fuel Cycle, Report by an Nea Group of Experts, Nuclear Energy Agency, Paris, France.

Nenoff, T.M., T.J. Garino, J.L. Krumhansl, D. Rademacher, R.T. Jubin, and D. Haefner. 2008. Waste Form Development and Testing for $I_{2}$, AFCI-WAST-PMO-MI-DV-2009-000156, Sandia National Laboratories, Albuquerque, NM.

Nenoff, T.M., T.J. Garino, J.L. Krumhansl, and D.F. Sava. 2011. Report on Iodine Containing Waste Forms, FCRD-SWF-2011-000159, Sandia National Laboratories, Albuquerque, NM.

Nenoff, T.M., J.L. Krumhansl, T.J. Garino, N.W. Ockwig. 2012. "Low Sintering Temperature Glass Waste Form for Sequestering Radioactive Iodine," U.S. Patent 8,262,950

Nenoff, T.M., M.A. Rodriguez, N. Soelberg, K.A. Chapman. 2014a "Silver-Mordenite for Radiological Gas Capture from Complex Streams: Dual Catalytic $\mathrm{CH}_{3} \mathrm{I}$ Decomposition and I Confinement," Micro. Meso. Mater., , 200, 297-303.

Nenoff, T.M., P.V. Brady, C.D. Mowry, and T.J. Garino. 2014b. $\mathrm{CH}_{3} I$ Loading and Sintering Effects on AgI-MOR GCM Durability, FCRD-SWF-2014-000591, Sandia National Laboratories, Albuquerque, NM.

Nenoff, T.M., P.V. Brady, C.D. Mowry, and T.J. Garino. 2014c. AgI-MOR Loading Effect on the Durability of the Sandia Low Temperature Sintering GCM Waste Form, FCRD-SWF-2014-000287, Sandia National Laboratories, Albuquerque, NM.

Nenoff, T.M., P.V. Brady, C.D. Mowry, and T.J. Garino. 2014d. Effect of Particle Size on Iodine Laded Ag-MOR on Final GCM Waste Form, FCRD-SWF-2014-000472, Sandia National Laboratories, Albuquerque, NM.

Ni, M., Y. Wang, B. Yuan, J. Jiang, and Y. Wu. 2013. "Tritium Supply Assessment for ITER and Demonstration Power Plant," Fusion Eng. Des., 88(9-10):2422-2426. 10.1016/j.fusengdes.2013.05.043.

Notz, K.J. 1980. "Processes for the Control ${ }^{14} \mathrm{CO}_{2}$ During Reprocessing," the International Symposium on Management of Gaseous Wastes from Nuclear Facilities, International Atomic Energy Agency, Vienna, Austria.

NRC. 2012. Chapter 10 Energy: Part 20 - Standards for Protection against Radiation, 10CFR20. U.S. Nuclear Regulatory Commission, Washington, D.C.

OECD, NEA. 2009. Mobile Fission and Activation Products in Nuclear Waste Disposal, NEA-6310, Organisation for Economic Co-Operation and Development, Nuclear Energy Agency, Paris, France.

Offutt, G.F. and C.L. Bendixsen. 1969. Rare Gas Recovery Facility at the Idaho Chemical Processing Plant, IN-1221, TID-4500, Idaho Nuclear Corporation, Idaho Falls, ID.

O'Holleran, T. P. to S.G. Johnson. 1999. “Ceramic Waste Form Intergranular Glass Composition,” ANLW Memo ENT-NWM-(TPO)-99-010, Argonne National Laboratory, Idaho Falls, ID.

Ojovan, M.I. and W.E. Lee. 2005. An Introduction to Nuclear Waste Immobilization. Elsevier, Oxford, U.K. 
Olson, L. 2012. Formulation of Reference Alloy Waste Form RAW-3, FCRD-SWF-2012-000348, Savannah River National Laboratory, Aiken, SC.

Olson, L. and S. Frank. 2012. Effect of Cr Content in Metallic Waste Forms: Oxidation Layer Formation, Electrochemistry, and Morphology, FCRD-SWF-2012-000161, Savannah River National Laboratory, Aiken, SC.

Ogata, Y., Y. Sakuma, N. Ohtani, and M. Kotaka. 2003. "Tritium Separation from Heavy Water by Electrolysis with Solid Polymer Electrolyte," Journal of Radioanalytical and Nuclear Chemistry, 255(3):539-541. DOI 10.1023/A:1022592601787.

Ogata, Y., Y. Sakuma, N. Ohtani, and M. Kotaka. 2005. "Tritium Separation by Electrolysis Using Solid Polymer Electrolyte," Fusion Science and Technology, 48(1):136-139.

Paek, S., M. Lee, K.R. Kim, D.H. Ahn, K.M. Song, and S.H. Shon. 2008. "Development of Tritium Storage and Transport Vessels," Waste Management 2008, Paper 8128 pp. Phoenix, AZ.

Palamalai, A., S.V. Mohan, and G.R. Balasubramanian. 1983. Simple Regeneration Method of Spent Mercurex Scrub. In Proceedings Dep. At. Energy, India.

Park J-K. 2010. CCIM Installation and Commissioning - Lessons Learned, Final Report for Subcontract AC69533N, Korea Hydro and Nuclear Power Co., Ltd. Daejeon, Republic of Korea.

Pence, D.T. and C.-C. Chou. 1981. "Treating a Nuclear Process Off-Gas Stream," Patent No. WO8100413A1.

Penzhorn, R.D., P. Schuster, H.E. Noppel, and L.M. Hellwig. 1980. Long-Term Storage of Krypton-85 in Zeolites. In Proceedings of the International Symposium on Management of Gaseous Wastes from Nuclear Facilities, IAEA-SM-245/10, International Atomic Energy Agency,

Pereira, C., M.C. Hash, M.A. Lewis, M.K. Richmann, and J. Basco. 1999. "Incorporation of Radionuclides from the Electrometallurgical Treatment of Spent Fuel into a Ceramic Waste Form," Scientific Basis for Nuclear Waste Management XXII, Vol. 556, 115-120 pp. American Ceramic Society, Warrrendale, PA.

Pereira, C., M. C. Regalbuto, G. F. Vandegrift, A. Bakel, J. Basco, D. Bowers, J. P. Byrnes, M. A. Clark, C. Cramer, J. R. Falkenberg, A. V. Guelis, L. Hafenrichter, M. Kalensky, J. F. Krebs, A. Leyva, L. Miller, B. Shroy, V. Sullivan, Y. Tsai, K. J. Quigley, and A. Wright. 2006. Preliminary Results of the UREX+1a Spent Fuel Process Demonstration. Argonne National Laboratory Letter Report, September 30, 2006.

Pickrell, M.M., A.D. Lavietes, V. Gavron, D. Henzlova, H.O. Menlove, M.J. Joyce, and R.T. Kouzes. 2013. "The IAEA Workshop on Requirements and Potential Technologies for Replacement of ${ }^{3} \mathrm{He}$ Detectors in IAEA Safeguards Applications," JNMM, 41(2):14-29.

Poncelet, F.J., D. Hugelmann, D. Saudray, S. Mukohara, and A. Cho. 1991 Head-End Process Technology for the New Reprocessing Plants in France and Japan. In Proceedings of $3^{\text {rd }}$ International Conference on Nuclear Fuel Reprocessing and Waste Management (RECOD' 91), Tokyo, Japan.

Priebe, S. 2007. "The Ceramic Waste Form Process at Idaho National Laboratory," 26th International Conference on Incineration and Thermal Treatment Technologies, 763-775 pp. Air and Waste Management Association, Phoenix, AZ. 
Priebe, S. and K. Bateman. 2008. "The Ceramic Waste Form Process at Idaho National Laboratory," Nuclear Technology, 162:199-207.

Psarros, N., H. Duschner, D. Molzahn, L. Schmidt, and S. Heise. 1990. Untersuchungen Zum Jodaustausch aus Schwerfluechtigen Verbindungen. Schlussbericht. (Investigations Concerning the Exchange of Iodine from Non-Volatile Organic Iodine Compounds. Final Report), Marburg University, Marbure, Germany.

Rao, B.S.M., E. Gantner, J. Reinhardt, D. Steinert, and H.J. Ache. 1990. "Characterization of the Solids Formed from Simulated Nuclear Fuel Reprocessing Solutions," Journal of Nuclear Materials, 170:39-49.

Ren, X., K. Sridharan, and T.R. Allen. 2006. "Corrosion of Ferritic-Martensitic Steel HT9 in Supercritical Water," Journal of Nuclear Materials, 358:227-234.

Reynes, J., T. Woignier, and J. Phalippou. 2001. "Permeability measurement in composite aerogels: application to nuclear waste storage," Journal of Non-Crystalline Solids, 285(1-3):323-327. DOI 10.1016/S0022-3093(01)00474-4.

Riley, B.J., B.T. Rieck, J.S. Mccloy, J.V. Crum, S.K. Sundaram, and J.D. Vienna. 2012a. "Tellurite Glass as a Waste Form for Mixed Alkali-Chloride Waste Streams: Candidate Materials Selection and Initial Testing," Journal of Nuclear Materials, 424(1-3):29-37. DOI 10.1016/j.jnucmat.2012.01.024.

Riley, B.J., J.V. Crum, J. Matyas, J.S. Mccloy, and W.C. Lepry. 2012b. "Solution-Derived, ChlorideContaining Minerals as a Waste Form for Alkali Chlorides," Journal of the American Ceramic Society, 95(10):3115-3123. DOI 10.1111/j.1551-2916.2012.05363.x.

Riley, B.J., M.J. Schweiger, D.S. Kim, W.W. Lukens, B.D. Williams, C. Iovin, C.P. Rodriguez, N.R. Overman, M.E. Bowden, D.R. Dixon, J.V. Crum, J.S. Mccloy, and A.A. Kruger. 2014. "Iodine Solubility in a Low-Activity Waste Borosilicate Glass at $1000^{\circ} \mathrm{C}$," Journal of Nuclear Materials, 452(1-3):178-188. DOI 10.1016/j.jnucmat.2014.04.027.

Ringel, H.D. 1990. "Development of a Process for Adsorptive Separation of Kr-85 from Off-Gas of Nuclear Facilities," the $21^{\text {st }}$ DOE/NRC Nuclear Air Cleaning Conference (CONF-900813, Vol. 1), US Department of Energy, Washington, DC.

Ringel, H.D., H. Barnert-Wiemer, H. Hackfort, and M. Heidendael. 1981. "Conditioning of Reprocessing Dissolver Offgas Prior to Krypton Retention by Cryogenic Distillation," Proc. DOE Nucl. Air Clean. Conf., 16(1):585-596.

Ringwood, A.E., S.E. Kesson, and N.G. Ware. 1980 Immobilization of U. S. Defense Nuclear Wastes Using the Synroc Process. In Proceedings of Scientific Basis for Nuclear Waste Management, 2, Plenum Press,

Ringwood, A.E., K.D. Reeve, and J.D. Tewhey. 1981 Recent Progress on Synroc Development. In Proceedings of Scientific Basis of Nuclear Waste Management, Plenum Press,

Robinson, S. and R. Jubin. 2013. Review of Tritium in Zircaloy Cladding from Light Water Reactors, FCRD-SWF-2013-000288, Oak Ridge National Laboratory, Oak Ridge, TN. 
Rocca, F., G. Dalba, P. Fornasini, and A. Tomasi. 1992. "Structural Study of AgI- $\mathrm{Ag}_{2} \mathrm{O}-\mathrm{B}_{2} \mathrm{O}_{3}$ Glasses By X-Ray Absorption-Spectroscopy," Solid State Ionics, 53:1253-1259.

Rodger, W.A. and S.L. Reese. 1969. "Removal of Iodine from Reprocessing-Plant Effluents," Reactor and Fuel-Processing Technology, 12(2):173-180.

Rohatgi, A. and D.M. Strachan. 2011. Potential Production Technologies for E-Metal, Tc, and Noble Metals - an Initial Assessment, Pacific Northwest National Laboratory, Richland, WA.

Rocca, F., G. Dalba, P. Fornasini, and A. Tomasi. 1992. "Structural Study of AgI- $\mathrm{Ag}_{2} \mathrm{O}-\mathrm{B}_{2} \mathrm{O}_{3}$ Glasses By X-Ray Absorption-Spectroscopy," Solid State Ionics, 53:1253-1259.

Rocca, F., A. Kuzmin, P. Mustarelli, C. Tomasi, and A. Magistris. 1999. "XANES and EXAFS at Mo Kedge in $(\mathrm{AgI})_{1-x}\left(\mathrm{Ag}_{2} \mathrm{MoO}_{4}\right)_{x}$ glasses and crystals," Solid State Ionics, 121(1-4):189-192.

Romanovsky, V.N. 2003. "Management of Accumulated High Level Waste at the Mayak Production Association in the Russian Federation," Issues and Trends in Radioactive Waste Managment, Proceedings:359-372, International Atomic Energy Agency, Vienna, Austria.

Rousselot, C., J.P. Malugani, R. Mercier, M. Tachez, P. Chieux, A.J. Pappin, and M.D. Ingram. 1995. "The origins of neutron-scattering prepeaks and conductivity enhancement in AgI-containing glasses," Solid State Ionics, 78(3-4):211-221. 10.1016/0167-2738(95)00103-d.

Rudisill, T.S. 2008. Decontamination of Zircaloy Cladding Hulls from Spent Nuclear Fuel, WSRC-STI2008-00075, Savannah River National Laboratory, Aiken, SC.

Ryan, J.V., G.F. Piepel, A.L. Billings, J.C. Marra, C.S. Ray, J.V. Crum, J. Lang, and C. Rodriguez. 2009. FY09 Combined Waste Streams Glass Testing-Summary Report; Advanced Fuel Cycle Initiative, AFCIWAST-WAST-MI-DV-2010-000022, Pacific Northwest National Laboratory, Richland, WA.

Sakuragi, T., T. Nishimura, Y. Nasu, H. Asano, K. Hoshino, and K. Iino. 2008. "Immobilization of radioactive iodine using AgI vitrification technique for the TRU wastes disposal: Evaluation of leaching and surface properties," Scientific Basis for Nuclear Waste Management XXXI, Vol. 1107, 279-285 pp. Materials Research Society, Warrendale, PA.

Sakurai, T., A. Takahashi, N. Ishikawa, and Y. Komaki. 1991. "The Interaction of Iodine with Insoluble Residue in the Dissolution of Simulated Spent-Fuel Pellets," Nuclear Technology, 94(1):99-107.

Sakurai, T., A. Takahashi, N. Ishikawa, Y. Komaki, M. Ohnuki, and T. Adachi. 1992. "The Iodine Species and Their Behavior in the Dissolution of Spent-Fuel Specimens," Nuclear Technology, 99(1):7079.

Sakurai, T. and A. Takahashi. 1994. "Catalytic Effect of Silver-Impregnated Silica-Gel (AgS) on Reaction of Methyl Iodide with Nitrogen Dioxide," Journal of Nuclear Science and Technology, 31(1):86-87.

Sakurai, T., K. Komatsu, and A. Takahashi. 1997. "Behavior of Iodine in the Dissolution of Spent Nuclear Fuels," 24th DOE/NRC Nuclear Air Cleaning and Treatment Conference, 550-562 pp. Portland, OR. 
Salmon, P.S. and S. Xin. 2002. "Chalcohalide glasses: The effect of covalent versus ionic bonding in $(\mathrm{CuI})_{0.6}\left(\mathrm{Sb}_{2} \mathrm{Se}_{3}\right)_{0.4}, "$ Physical Review B, 65(6):064202.

Sanghera, J.S., J. Heo, and J.D. Mackenzie. 1988. "Chalcohalide glasses," Journal of Non-Crystalline Solids, 103(2-3):155-178. DOI: 10.1016/0022-3093(88)90196-2.

Sanson, A., F. Rocca, G. Dalba, P. Fornasini, and R. Grisenti. 2007a. "Influence of temperature on the local structure around iodine in fast-ion-conducting $\mathrm{Agl}: \mathrm{Ag}_{2} \mathrm{MoO}_{4}$ glasses," New Journal of Physics, 9:13. 88. DOI: $10.1088 / 1367-2630 / 9 / 4 / 088$.

Sanson, A., F. Rocca, P. Fornasini, G. Dalba, R. Grisenti, and A. Mandanici. 2007b. "Thermal behaviour of the local environment around iodine in fast-ion-conducting AgI-doped glasses," Philosophical Magazine, 87(3-5):769-777. DOI: 10.1080/14786430601032394.

Sava, D.F., K.W.Chapman, M.A. Rodriguez, J.A. Greathouse, P.S. Crozier, H. Zhao, P.J. Chupas, and T.M. Nenoff. 2013. "Competitive $\mathrm{I}_{2}$ Sorption in Cu-BTC from Humid Gas Streams," Chem. Mater., 25 (13), 2591-2596.

Scheele, R.D., L.L. Burger, and C.L. Matsuzaki. 1983. Methyl Iodide Sorption by Reduced Silver Mordenite, PNL-4489, Pacific Northwest Laboratory, Richland, WA.

Scheele, R.D., C.F. Wend, W.C. Buchmiller, A.E. Kozelisky, and R.L. Sell. 2002. Preliminary Evaluation of Spent Silver Mordenite Disposal Forms Resulting from Gaseous Radioiodine Control at Hanford's Waste Treatment Plant, Pacific Northwest National Laboratory, Richland, WA.

Schneider, K. J, Editor. 1969. Waste Solidification Program, Volume 1, Process Technology - Pot, Spray and Phosphate Glass Solidification Processes, BNWL-1073, Battelle Northwest Laboratory, Richland, WA.

Schneider, K. J. and V. P. Kelly. 1969. Waste Solidification Program, Volume 2, Design Features of the Waste Solification Engineering Prototype, BNWL-968, Battelle Northwest Laboratory, Richland, WA.

Senapati, H. and C. Austen Angell. 1991. "Glass formation and anomalous annealing effects in the mixed oxyanion system $\mathrm{AgI} \cdot \mathrm{Ag}_{2} \mathrm{SO}_{4} \cdot \mathrm{Ag}_{2} \mathrm{WO}_{4}$," Journal of Non-Crystalline Solids, 130(1):58-66. DOI: 10.1016/0022-3093(91)90156-z.

Serne, R.J. and J.H. Westsik. 2011. Data Package for Secondary Waste Form Down-Selection-Cast Stone, Pacific Northwest National Laboratory, Richland, WA.

Shaffer, J.H. 1983. Head-End Processing of Spent Breeder Reactor Fuels: Status of Laboratory Research and Development Activities, ORNL/TM-8710, Union Carbide Corporation, Oak Ridge National Laboratory, Oak Ridge, TN.

Sheppard, G.P., J.A. Hriljac, E.R. Maddrell, and N.C. Hyatt. 2006. "Silver Zeolites: Iodide Occlusion and Conversion to Sodalite - a Potential ${ }^{129}$ I Waste Form?," in Mater. Res. Soc. Symp. Proc., 932(Scientific Basis for Nuclear Waste Management XXIX):775-782.

Sienkiewicz, C.J. and J.E. Lentz. 1988. "Recovery of Tritium from Water," Fusion Technology, 14:444449. 
Simpson, M.F. 2013. "Projected Salt Waste Production from a Commercial Pyroprocessing Facility," Science and Technology of Nuclear Installations, 2013:Article 945858.

http://dx.doi.org/10.1155/2013/945858.

Simpson, M.F. and P. Sachdev. 2008. "Development of Electrorefiner Waste Salt Disposal Process for the EBR-II Spent Fuel Treatment Project " Nuclear Engineering and Technology, 40(3):175-182.

Simpson, M.F., K.M. Goff, and S.G. Johnson. 2001. "A Description of the Ceramic Waste Form Production Process from the Demonstration Phase of the Electrometallurgical Treatment of EBR-II Spent Fuel," Nuclear Technology, 134(3):263-277.

Simpson, M.F., T.S. Yoo, R.W. Benedict, S. Phongikaroon, S. Frank, P. Sachdev, and K. Hartman. 2007. "Strategic Minimization of High Level Waste from Pyroprocessing of Spent Nuclear Fuel," Global 2007, American Nuclear Society, LaGrange Park, IL.

Sinkler, W., T.P. O'holleran, S.M. Frank, M.K. Richmann, and S.G. Johnson. 2000. "Characterization of a Glass-Bonded Ceramic Waste Form Loaded with U and Pu," Scientific Basis for Nuclear Waste Management XXIII, Vol. 608, 423-429 pp. Materials Research Society, Warrendale, PA.

Soelberg, N.R. 2001. "Offgas Control for Mixed Waste Thermal Treatment Systems." In Hazardous and Radioactive Waste Treatment Technologies Handbook, ed. C.H. Oh. CRC Press, Washington, D.C.

Soelberg, N.S., J. Roach, M. Ancho, and J. Richardson. 2009. “ART CCIM Phase II-A Off-Gas System Evaluation Test Report,” INL/EXT-09-15711, Idaho National Laboratory, Idaho Falls, ID.

Soelberg, N.R., T.G. Garn, M.R. Greenhalgh, J.D. Law, R.T. Jubin, D.M. Strachan, and P.K. Thallapally. 2013. "Radioactive Iodine and Krypton Control for Nuclear Fuel Reprocessing Facilities," Science and Technology of Nuclear Installations, 2013:Article ID 702496. doi:10.1155/2013/702496.

Soelberg, N.R. and T. Watson. 2012. Iodine Sorbent Performance in FY 2012 Deep Bed Tests, FCRDSWF-2012-000278, Idaho National Laboratory, Idaho Falls, ID.

Sombret, C. 1983. "The Status of French High-Level Radioactive Wastes Solidification." In The Treatment and Handling of Radioactive Wastes, eds. A.G. Blasewitz, J.M. Davis and M.R. Smith. Battelle Press, Columbus, $\mathrm{OH}$.

Sood, S.K., J. Quelch, and R.B. Davidson. 1990. "Fusion Technology Experience at Ontario Hydro's Darlington Tritium Removal Facility and Heavy Water Upgraders," Fusion Engineering and Design, 12(3):365-371. http://dx.doi.org/10.1016/0920-3796(90)90009-U.

Sood, S., O. Kveton, D. Spagnolo, and P. Gierszewski. 1995. Iter Task D55: Design of Water Detritiation Plant, CFFTP G-9502, Ontario Hydro, Canada, Mississauga, Ontario Canada.

Song, K.C., G. Park, J.W. Lee, J.J. Park, and M.S. Yang. 2008. "Fractional Release Behavior of Volatile and Semivolatile Fission Products During a Voloxidation and OREOX Treatment of Spent PWR Fuel," Nuclear Technology, 162(2):158-168.

Souto, S., M. Massot, and M. Balkanski. 1994. "Raman scattering and medium range order in ternary borate glasses," Solid State Ionics, 70-71(Part 1):350-355. 
Spencer, B. B., Welch, T. D., and Whatley, M. E. 1983. Description of a Full-Scale Experimental Voloxidizer Facility, ORNL-5924, Union Carbide Corp., Oak Ridge National Laboratory, Oak Ridge, TN.

Spencer, B.B. and G.D. Delcul. 2010. Engineering Analysis of Voloxidation Process, ORNL/TM2009/208, Oak Ridge National Laboratory, Oak Ridge, TN.

Spencer, B.B., S.H. Bruffey, J.F. Walker, K.K. Anderson, and R.T. Jubin. 2013. Iodine and Water CoAdsorption and Desorption on Deep Beds of $3 A$-Molecular Sieve and Silver Mordenite, FCRD-SWF2013-000329, Oak Ridge National Laboratory, Oak Ridge, TN.

Spoerke, E., J. Wheeler, J. Ihlefeld, M. Blea, K. Waldrip, and L. Johnson. 2013. Ion Selective Ceramics for Waste Separations: End of Fiscal Year Project Assessment, FCRD-SWF-2013-000300, Sandia National Laboratories, Albquerque, NM.

Spoerke, E., J. Wheeler, J. Ihlefeld, M. Blea, H. Brown-Shaklee, and M. Rodriguez. 2014. Ion Selective Ceramics for Waste Separations: Performance and Design of Ion Selective Ceramic Membrane for Molten Salt Recycle, FCRD-SWF-2014-000033, Sandia National Laboratories, Albquerque, NM.

Stanworth, J.E. 1952. "Tellurite Glass," Journal of the Society of Glass Technology, 36 (171):217-241.

Stasko, R.R. and G.A. Vivian. 1982. "An Overview of the Ontario Hydro Carbon-14 Control Program," In Proceedings of the Managemenr and Annual Information Meeting on NFWMP, Canadian Nuclear Society: Winnipeg, Manitoba, Canada.

Stefanovsky, S.V., A.G. Ptashkin, O.A. Knyazev, S.A. Dmitriev, S.V. Yudintsev, and B.S. Nikonov. 2007. "Inductive Cold Crucible Melting of Actinide-Bearing Murataite-Based Ceramics," Journal of Alloys and Compounds, 444:438-442. DOI: 10.1016/j.jallcom.2007.01.067.

Strachan, D.M. 1978. Analysis of the Dissolver Silver Reactors from Hanford's Purex Plant, RHO-ST-2, Rockwell Hanford Operations, Richland, WA.

Strachan, D.M., J.V. Crum, E.C. Buck, B.J. Riley, and M.R. Zumhoff. 2010. Fiscal Year 2010 Summary Report on the Epsilon-Metal Phase as a Waste Form for ${ }^{99}$ Tc, Pacific Northwest National Laboratory, Richland, WA.

Strachan, D.M., J.V. Crum, M.R. Zumhoff, C.C. Bovaird, J. C.F. Windisch, and B.J. Riley. 2011 a. Epsilon Metal Summary Report Fiscal Year 2011, Pacific Northwest National Laboratory, Richland, WA.

Strachan, D.M., J. Chun, J. Matyas, W.C. Lepry, B.J. Riley, J.V. Ryan, and P.K. Thallapally. 2011 . Summary Report on the Volatile Radionuclide and Immobilization Research for FY2011 at PNNL, FCRD-SWF-2011-000378, PNNL-20807, Pacific Northwest National Laboratory, Richland, WA.

Streatfield, R. 2001. "A Review and Update of the Bnfl Cement Formulation Development Programme for the Immobilisation of Intermediate Level Wastes from Magnox Power Stations," Waste Management 2001, 52-02 pp. Tucson, AZ.

Swift, P.N. and W.M. Nutt. 2012. "Applying Insights from Repository Safety Assessments to Evaluating Impacts of Partitioning and Transmutation," 11th Actinide and Fission Product Partitioning and Transmutation, 145-154 pp. OECD, Nuclear Energy Agency. 
Tamekiyo, Y., T. Okada, T. Kishimoto, T. Kanazawa, T. Fujii, and K. Ishiyama. 1983. "Krypton Recovery Pilot Plant," R\&D, Res. Dev., 33(1):10-16.

Tanabe, H., T. Sakuragi, K. Yamaguchi, T. Sato, and H. Owada. 2010. "Development of new waste forms to immobilize iodine-129 released from a spent fuel reprocessing plant," Adv. Sci. Technol. (StafaZuerich, Switz.), 73(5th Forum on New Materials, 2010, Part B):158-170. DOI:

10.4028/www.scientific.net/AST.73.158.

Tang, G., Z. Yang, L. Luo, and W. Chen. 2008. "Formation and Properties of $\mathrm{GeSe}_{2}-\mathrm{Ga}_{2} \mathrm{Se}_{3}-\mathrm{PbI}_{2} \mathrm{Novel}$ Chalcohalide Glasses," Journal of the American Ceramic Society, 91(5):1686-1689. DOI: 10.1111/j.15512916.2008.02321.x.

Thallapally, P.K. and D.M. Strachan. 2012. Initial Proof-of-Principle for near Room Temperature Xe and Kr Separation from Air with MOFs, PNNL-21452, Pacific Northwest National Laboratory, Richland, WA.

Thallapally, P.K., J. Liu, and D.M. Strachan. 2013. Demonstrate the Removal Efficiency and Capacity of MOF Materials for Krypton Recovery, PNNL-22693, Pacific Northwest National Laboratory, Richland, WA.

Thomas, T.R., L.P. Murphy, B.A. Staples, and J.T. Nichol. 1977. Airborne Iodine Loading Capacities of Metal Zeolites and a Method for Recycling Silver Zeolite, Allied Chemical Co., Idaho Falls, ID.

Tits, J., A. Jakob, E. Wieland, and P. Spieler. 2003. "Diffusion of Tritiated Water and ${ }^{22} \mathrm{Na}^{+}$through NonDegraded Hardened Cement Pastes," Journal of Contaminant Hydrology, 61:45-62.

Todd, T.A. and J.D. Vienna. 2012. Separations and Waste Forms Campaign Implementation Plan, FCRD-SWF-2012-00123, Rev. 1, U.S. Department of Energy, Office of Nuclear Energy, Idaho Falls, ID.

Toyohara, M., M. Kaneko, N. Mitsutsaka, H. Fujihara, N. Saito, and T. Murase. 2002. "Contribution to Understanding Iodine Sorption Mechanism onto Mixed Solid Alumina Cement and Calcium Compounds," Journal of Nuclear Science and Technology, 39 950-956.

Trevorrow, L.E., V.N. Kolba, G.F. Vandergrift, and M.J. Steindler. 1983. Compatibility of Technologies with Regulations in the Waste Management of H-3, I-129, C-14, and Kr-85. Part II. Analysis, Argonne National Laboratory, Argonne, IL.

Troles, J., F. Smektala, G. Boudebs, and A. Monteil. 2003. "Third order nonlinear optical characterization of new chalcohalogenide glasses containing lead iodine," Optical Materials, 22(4):335-343. DOI: $10.1016 / \mathrm{s} 0925-3467(02) 00345-2$.

Tunaboylu, K., M. Paulovic, and D. Ulrich. 1991. "Concept of a Tritium Extraction Facility for a Reprocessing Plant," Nuclear Engineering and Design, 130(1):71-76. http://dx.doi.org/10.1016/00295493(91)90194-M.

Uchiyama, G., M. Kitamura, K. Yamazaki, S. Torikai, S. Sugikawa, M. Maeda, and T. Tsujino. 1992. "Study on Voloxidation Process for Tritium Control in Reprocessing," Radioactive Waste Management and Environmental Restoration, 17(1):63-79.

Utsunomiya, S. and R.C. Ewing. 2006. "The Fate of the Epsilon Phase (Mo-Ru-Pd-Tc-Rh) in the $\mathrm{UO}_{2}$ of the Oklo Natural Fission Reactors," Radiochimica Acta, 94:749-753. 
Vance, E.R. 1986. "Sol-gel production of titanosilicate glass-ceramics for nuclear waste immobilization," Journal of Material Science, 21(4):1413-1416.

Vienna, J.D., J. Luey, P. Hrma, H. Li, D.E. Smith, R.D. Scheele, H.L. Wigent, and J.V. Crum. 1999. "Glass frit development for encapsulation of rocky flats ash," Ceramic Transactions, Vol. 93, 399-407 pp. American Ceramic Society, Westerville, OH.

Vienna, J.D. 2010. "Nuclear Waste Vitrification in the United States: Recent Developments and Future Options," International Journal of Applied Glass Science 1(3):309-321.

Vienna, J.D., J.V. Crum, G.J. Sevigny, and G.L. Smith. 2012. Preliminary Technology Maturation Plan for Immobilization of High-Level Waste in Glass-Ceramics, FCRD-SWF-2012-000152, Pacific Northwest National Laboratory, Richland, WA.

Vienna, J.D., J.V. Ryan, S. Gin, and Y. Inagaki. 2013. "Current Understanding and Remaining Challenges in Modeling Long-Term Degradation of Borosilicate Nuclear Waste Glasses," International Journal of Applied Glass Science, 4(4):283-294.

Volkovich, V.A., T.R. Griffiths, and R.C. Thied. 2003. "Treatment of Molten Saltwastes by Phosphate Precipitation: Removal of Fission Product Elements after Pyrochemical Reprocessing of Spent Nuclear Fuels in Chloride Melts," Journal of Nuclear Materials, 323(1):49-56.

Von Ammon, R. 1987. "Removal of Krypton from the Offgas of Nuclear Reprocessing Plants," GIT Fachz. Lab., 31(10):906-908, 910-912, 912,914-915.

Von Lensa, W., R. Nabbi, M. Rossbach, D. Greneche, B. Quiniou, L. Boucher, M. Delpech, E. Gonzalez, F. Alvarez, M.A. Cunado, G. Serrano, J.L. Cormenzana, W. Kuckshinrichs, R. Odoj, J. Wallenius, D. Westlen, C. Zimmerman, and J. Marivoet. 2008. RED-IMPACT: Impact of Partitioning, Transmutation, and Waste Reduction Technologies on the Final Nuclear Waste Disposal -- Synthesis Report. Reihe Energie \& Umwelt / Energy \& Environment, Forschungszentrum Julich GmbH Zentralbibliothek, Verlag, Julich, GmbH.

Watson, L.C., R.C. Duram, W.E. Erlebach, and H.K. Rae. 1958. "The Disposal of Fission Products in Glass," In Proceedings of The 2nd United Nations International Conference on Peaceful Uses of Atomic Energy, 18, 27, United Nations, NY.

Weinlaender, W., K.L. Huppert, and M. Weishaupt. 1991. "Twenty Years of WAK Reprocessing Pilot Plant Operation," In Proceedings of $3^{\text {rd }}$ International Conference on Nuclear Fuel Reprocessing and Waste Management (RECOD' 91), Tokyo, Japan.

Weirich, F. 1989. "Krypton Removal from the Dissolver Offgas with the Solvent R-12," Nukl. Entsorgung, 4:189-199.

Westphal, B.R., S.M. Frank, W.M. Mccartin, D.G. Cummings, J.J. Giglio, T.P. O'holleran, P.A. Hahn, T.S. Yoo, K.C. Marsden, K.J. Bateman, and M.N. Patterson. 2013. "Characterization of Irradiated Metal Waste from the Pyrometallurgical Treatment of Used EBR-II Fuel," Metallurgical and Materials Transactions A. DOI: 10.1007/s11661-013-2114-z.

Westsik JH, Jr, GF Piepel, MJ Lindberg, PG Heasler, TM Mercier, RL Russell, A Cozzi, WE Daniel, Jr, RE Eibling, EK Hansen, MM Reigel, and DJ Swanberg. 2013. Supplemental Immobilization of Hanford 
Low-Activity Waste: Cast Stone Screening Tests. PNNL-22747, Pacific Northwest National Laboratory, Richland, WA.

White, J.M. and G. Lahaie. 1955. Ultimate Fission Product Disposal, the Disposal of Curie Quantities of Fission Products in Siliceous Materials, CRCE-591, Atomic Energy of Canada, Ltd., Pinawa, Canada.

Whitmell, D.S., L. Geens, R.D. Penzhorn, and M.J.S. Smith. 1987. "Capture and Immobilization of Krypton-85," In Radioactive Waste Management and Disposal, Commission of European Communities Report, EUR-10163, pp. 169-184, European Commission. Luxembourg

Wilhelm, J.G. and J. Furrer. 1977. "Iodine Release in Reprocessing Plants." In Seminar on Radioactive Effluents from Nuclear Fuel Reprocessing Plants. Schule für Kerntechnik Kernforschungszentrum, Kerlsruhe, Germany.

Wilhelm, J.G., J. Furrer, and E. Schultes. 1976 Head-End Iodine Removal from a Reprocessing Plant with a Solid Sorbent (CONF 760822). In Proceedings of the $14^{\text {th }}$ ERDA Air Cleaning Conference, Harvard Air Cleaning Laboratory, Boston, MA.

Willis, W., C. Phillips, R. Carter, S. Baker, W. Bowen, and M. Grygiel. 2013. LWR UOX and MOX Fuel Recycle and LWR MOX and Fast Reactor Fuel Fabrication Waste Estimates, Energy Solutions, Richland, WA.

Woignier, T., J. Reynes, J. Phalippou, J.L. Dussossoy, and N. Jacquet-Francillon. 1998. "Sintered silica aerogel: a host matrix for long life nuclear wastes," Journal of Non-Crystalline Solids, 225(1):353-357. DOI 10.1016/S0022-3093(98)00052-0.

Woignier, T., J. Reynes, J. Phalippou, and J.L. Dussossoy. 2000. "Nuclear waste storage in gel-derived materials," Journal of Sol-Gel Science and Technology, 19(1-3):833-837. DOI 10.1023/A:1008784822052.

Wood, W. and A.C.B. Richardson. 1977. Considerations Bearing on the Disposal of Iodine-129. In Proceedings NEA Specialist Meeting on Iodine-129, pp 90-100, Paris, France.

Yamanishi, T., Y. Iwai, Y. Kawamura, and M. Nishi. 2006. "A Design Study for Tritium Recovery System from Cooling Water of a Fusion Power Plant," Fusion Engineering and Design, 81(1-7):797-802. http://dx.doi.org/10.1016/j.fusengdes.2005.07.023.

Yang, J.H., J.M. Shin, J.J. Park, and G. Park. 2014. "Waste Form of Silver Iodide (AgI) with LowTemperature Sintering Glasses," Separation Science and Technology, 49:298-304. DOI: $10.1080 / 01496395.2013 .817424$.

Yang, Z., G. Tang, L. Luo, and W. Chen. 2007. "Visible Transparent $\mathrm{GeSe}_{2}-\mathrm{Ga}_{2} \mathrm{Se}_{3}-\mathrm{KX}(\mathrm{X}=\mathrm{I}, \mathrm{Br}$, or Cl) Glasses for Infrared Optics," Journal of the American Ceramic Society, 90(2):667-669. DOI:

10.1111/j.1551-2916.2006.01458.x.

Yarbro, O.O., W.S. Groenier, and M.J. Stephenson. 1976. "Airborne Effluent Control for LMFBR Fuel Reprocessing Plants," In Proceedings Meeting on Controlling Airborne Effluents from Fuel Cycle Plants, CONF-760806-6, pp. 22, Sun Valley, ID.

Yarbro, O.O., J.C. Mailen, and M.J. Stephenson. 1977. Retention of Gaseous Isotopes, LAEA-CN-36/408, International Atomic Energy Agency, Salzburg, Austria. 
Ying, S., W. Heyi, S. Ge, L. Yangming, C. Wei, L. Yingnu, and X. Yifu. 2008. "Study on the Technology of CECE-GC System for Water Detritiation," Fusion Engineering and Design, 83(10-12):1400-1404. http://dx.doi.org/10.1016/j.fusengdes.2008.08.043.

Yusa, H., M. Kikuchi, H. Tsuchiya, O. Kawaguchi, and T. Segawa. 1977. "Application of Cryogenic Distillation to Krypton-85 Recovery," Nucl. Eng. Des., 41(3):437-441. 10.1016/0029-5493(77)90084-X.

Zakharova, K.P., O.M. Khimchenko, L.P. Sukhanov, V.V. Aleksandrov, A.A. Sal'nikov, E.V. Khromovskikh, and V.M. Pushkarev. 2007. "Development of the Process Regime for Cementing Salt Concentrates from the Volgodonsk Nuclear Power Plant," Atomic Energy, 103(5):884-889.

Zhang, M., E.R. Maddrell, P.K. Abraitis, and E.K.H. Salje. 2007. "Impact of leach on lead vanadoiodoapatite $\left[\mathrm{Pb}_{5}\left(\mathrm{VO}_{4}\right)_{3} \mathrm{I}\right]$ : An infrared and Raman spectroscopic study," Materials Science and Engineering B, 137 149-155. 